$$
\text { UNIVERSIDADE DE SÃO PAULO }
$$

FACULDADE DE FILOSOFIA LETRAS E CIÊNCIAS HUMANAS PROGRAMA DE PÓS-GRADUAÇÃO EM SOCIOLOGIA

\author{
Flavia Mateus Rios
}

\title{
INSTITUCIONALIZAÇÃO DO MOVIMENTO NEGRO NO BRASIL CONTEMPORÂNEO
}

São Paulo 


\title{
UNIVERSIDADE DE SÃO PAULO
}

FACULDADE DE FILOSOFIA LETRAS E CIÊNCIAS HUMANAS

PROGRAMA DE PÓS-GRADUAÇÃO EM SOCIOLOGIA

\author{
Flavia Mateus Rios
}

\section{INSTITUCIONALIZAÇÃO DO MOVIMENTO NEGRO NO BRASIL CONTEMPORÂNEO}

\author{
Dissertação apresentada ao Programa de Pós-graduação em \\ Sociologia da Faculdade de Filosofia, Letras e Ciências \\ Humanas da Universidade de São Paulo como requisito \\ parcial para obtenção do título de Mestre em Sociologia. \\ Orientador: Prof Dr. Antonio Sérgio Guimarães
}

\section{São Paulo}


Á minha avó Arminda. 


\section{Agradecimentos}

Realizar esta dissertação não seria possível sem o estímulo e apoio de várias pessoas e instituições. Assim, sou grata a todos que direta ou indiretamente me ajudaram a construir este trabalho.

Inicialmente, gostaria de agradecer ao professor Antonio Sérgio Guimarães, meu orientador, pela confiança, pela compreensão e pelas leituras críticas dos capítulos da dissertação. Não tenho dúvidas de que seu projeto de formação de pesquisadores tem sido muito bem sucedido. Sem ele, nada disso seria possível.

Não poderia deixar de agradecer também aos membros da banca da qualificação, os professores Valter Roberto Silvério e Ângela Alonso, pelas questões e críticas contundentes, que foram fundamentais para orientar-me na escrita deste texto. Em especial, à professora Ângela, que leu atentamente muitas vezes os esboços de alguns capítulos e ajudou-me nos estudos sobre ação coletiva. Ângela, meus sinceros agradecimentos por sua paciência, dedicação e profissionalismo.

Agradeço à professora Márcia Lima e ao seu grupo de pesquisa, pelas leituras e apontamentos críticos aos meus escritos finais. Sem contar o ambiente agradável e produtivo criado em nossas reuniões quinzenais.

Agradeço à professora Gislene dos Santos, pela acolhida, indicações e iniciativas em projetos acadêmicos.

Sou grata também à professora Francine Saillant, da Universidade Canadense de Laval, pelo trabalho conjunto.

Dos apoios institucionais, sou grata à Capes, pela bolsa de estudos que foi fundamental para subsidiar esta pesquisa;

Ao COSEAS, pela moradia estudantil que garantiu minha permanência nesta Instituição Universitária;

À Educafro e ao CEERT, bem como à todas as organizações negras visitadas durante essa pesquisa. Em especial, aos entrevistados que disponibilizaram documentos, contatos, suas opiniões e histórias de vida. Em particular, à André Guimarães, pelas dicas de leitura e contribuições para entender melhor a dinâmica do movimento negro contemporâneo. 
Minha (e)terna gratidão vai para meus companheiros de caminhada, que me auxiliaram em diferentes momentos de minha vida acadêmica:

aos que me receberam quando cheguei na Universidade de São Paulo, são eles: Alex Ratts, Taynar Pereira, Rosane Borges, Petrônio Domingues, Andréia Lisboa, Márcio Macedo, Noel Carvalho, Batista Felix e Rosangela Malachias. Vocês ensinaram-me a dar os primeiros passos por aqui. Obrigada pelos conselhos, guardei-os para sempre.

ao Rafael e ao Nilton, pela lealdade, pelo empenho e pela participação constante em meu trabalho;

à Nane e ao Matheus, pelas discussões e pelas leituras atentas e críticas aos meus textos; ao Júlio, pela paciência, pelas correções da dissertação e conselhos acadêmicos;

a Jackeline, pelo companheirismo e pela ajuda na construção dos mapas;

aos meus amigos, Gel, Aline, Gabi, Brisa, Uvanderson, Ana Paula, Edvan, Adriana de Cássia, Brisa, Thiagão, Marcelo, Rinaldo, Danilo, Carlinhos pelos anos de amizade e parceria;

à minha família, pela perseverança na vida, apesar de tudo;

ao Gato de Jesus, porque pintou meus olhos. 


\section{SUMÁRIO}

INTRODUÇÃ

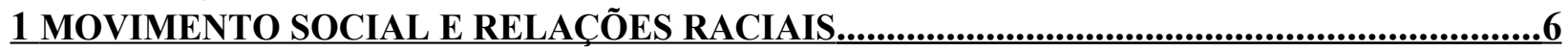

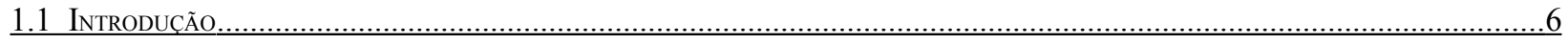

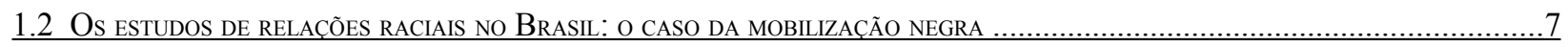

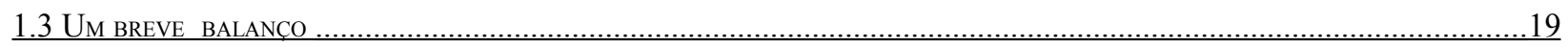

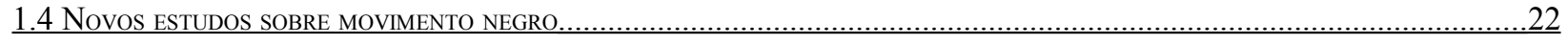

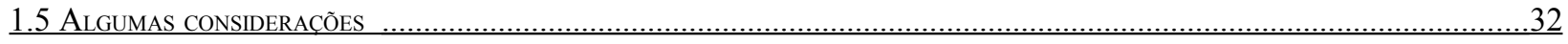

2 DA SOCIOLOGIA DOS MOVIMENTOS SOCIAIS À TEORIA DA AÇÃO COLETIVA.........35

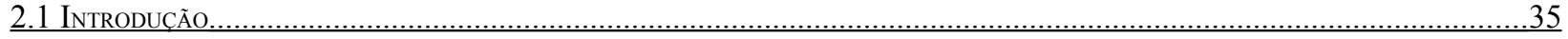

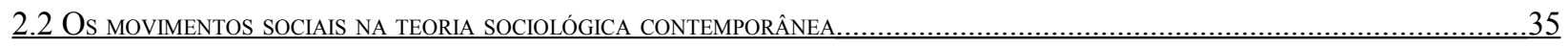

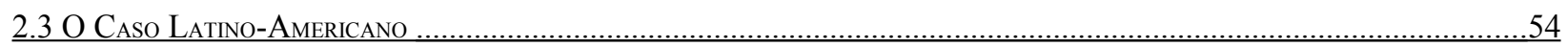

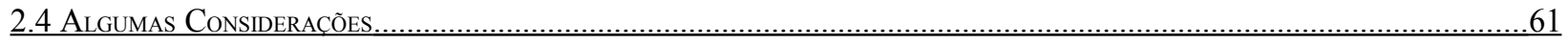

3 UM CASO DE INSTITUCIONALIZAÇÃO DO MOVIMENTO NEGRO: A FORMAC̣ÃO DA

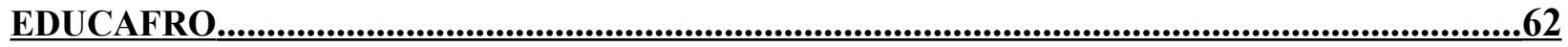

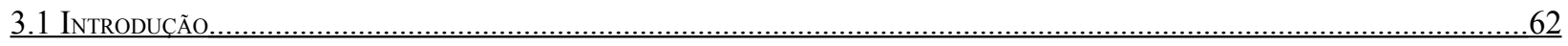

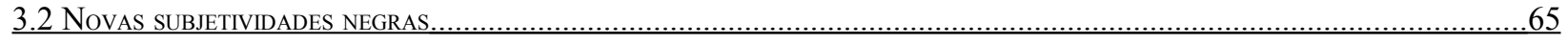

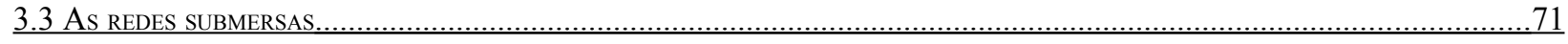

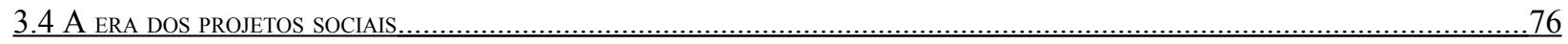

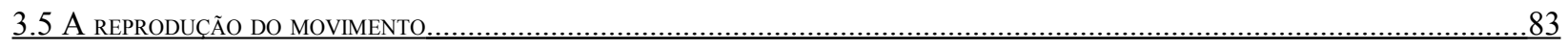

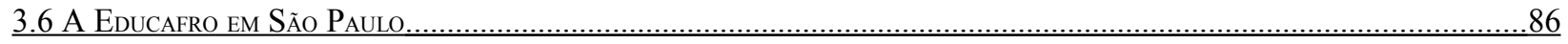

3.7 A INSTITUCIONALIZAÇ̃̃O E AS FORMAS DE PRESSÃO SOCIAL ...........................................................................................

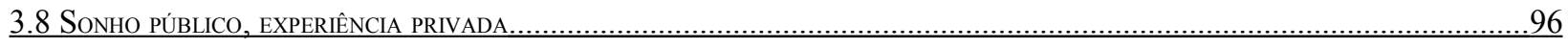

3.9 ENTRE OS SONHOS E AS ESTRATÉGIAS: UM PROJETO SOCIAL INTERNACIONALIZADO …………………………………….......101

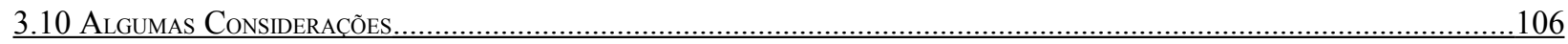

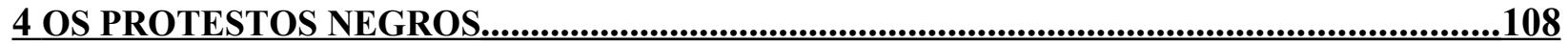

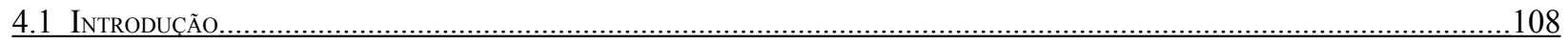

4.2 O ATO DE RE-FUNDAÇ̃̃O DO MOVIMENTO NEGRO

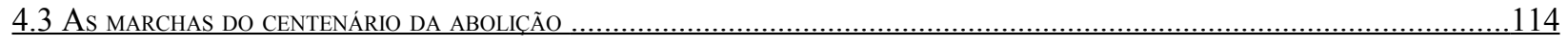

4.4 A marcha do tricentenário de Zumbi dos Palmares..........................................................................................

4.5 Encenando a história: Marcha Noturna pela Democracia Racial................................................................... 127

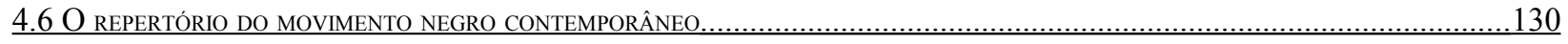

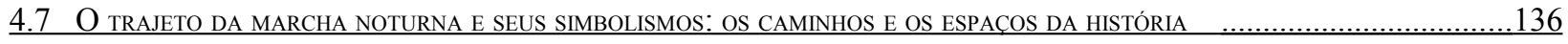

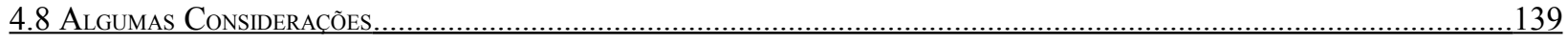

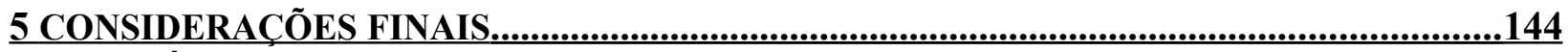

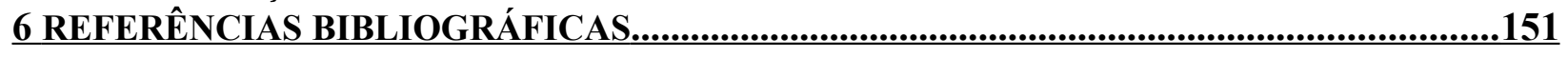




\title{
RESUMO
}

Nesta dissertação, investigo o processo de institucionalização do Movimento Negro no Brasil contemporâneo. Este fato social tem requerido uma progressiva profissionalização dos militantes, a formalização e burocratização das organizações, bem como novas estratégicas de mobilização de recursos e especialização do ativismo. Em grande medida, essa institucionalização está ligada ao modo pelo qual o movimento se apropriou das oportunidades políticas oferecidas pelo Estado e pelo ambiente civil a partir da redemocratização brasileira. A dinâmica das organizações e o estilo dos protestos negros, objetos empíricos deste trabalho, expressam o modo como a ação coletiva negra se insere no cenário político atual.

Palavras-chave: Movimento negro, relações raciais, ação coletiva, organizações negras, protestos.

\begin{abstract}
In this dissertation I analyse the institutionalization of black movement in Contemporary Brazil. This social fact have been imply progressive professionalization of militants, more formal and bureaucratic organizations, new strategies to resource mobilizations and specialization of activism. The institutionalization is related to the way through the movement used the political opportunities offered by state and environment civil since the emergency of Brazilian democracy in the 1980's. The dynamic of organizations and the style of black protest, empiric objects of this work, express how the collective actions inside nowdays political context.
\end{abstract}

Key-words: Black movement, racial relations, collective action, black organizations, protest. 


\section{INTRODUÇÃO}

Nesta dissertação, apresento o resultado da pesquisa que realizei, entre 2006 a 2008, sobre movimento negro contemporâneo. Minha preocupação era entender as causas e as conseqüências políticas da institucionalização crescente no movimento negro brasileiro nos últimos vinte anos. Com o intuito de descrever e explicar o referido processo, recorri à literatura das relações raciais e busquei, na produção internacional sobre ação coletiva, ferramentas analíticas para tratar do objeto. Essas investidas bibliográficas resultaram nos dois capítulos iniciais desta dissertação. Nos capítulos subseqüentes, apresento o exame dos dados coletados, que foram organizados a partir de duas unidades de análise distintas e complementares: a organização e o protesto, respectivamente.

"Movimento social e relações raciais" foi o nome dado ao primeiro capítulo deste trabalho, no qual procurei responder a duas perguntas: o que os estudos de relações raciais têm a dizer sobre a mobilização negra no Brasil? Quais são as interpretações sobre a emergência e o desenvolvimento do movimento negro contemporâneo na literatura sociológica? Para responder à primeira pergunta, detive-me, especialmente, nos trabalhos desenvolvidos pela UNESCO, nos anos de 1950, porque são os primeiros a dar um tratamento sociológico para esse tema e ainda são referências para os estudos contemporâneos. Já a segunda indagação me levou a perceber um grupo de intelectuais do movimento - emergente nos anos de 1970 -, cujos trabalhos mais maduros se fazem notar em forma de ensaios, escritos e publicados na década da redemocratização. Esses intelectuais oferecem suas interpretações sobre a mobilização racial daqueles anos; sucedem a esses ensaios um conjunto de pesquisas acadêmicas que seguem as pistas deixadas por essa intelectualidade militante. A partir dos anos 90, cientistas sociais de diferentes áreas escrevem suas teses e dissertações ${ }^{1}$, afastando-se dos escritos ensaísticos,

\footnotetext{
${ }^{1}$ Os materiais coletados para a análise desse capítulo foram teses, dissertações, capítulos de livros, artigos e ensaios em revistas especializadas, produzidos entre os anos de 1940 e de 2008 . Vale dizer: como se trata de uma análise da literatura acadêmica, ficou de fora a produção estritamente política dos ativistas, tais como artigos de jornais, revistas, entrevistas, panfletos e material em audiovisual. Essas fontes são riquíssimas para as análises dos capítulos terceiro e quarto. O material foi coletado pelo exame das referências bibliográficas dos pesquisadores do tema, pelo banco de dados das principais universidades brasileiras e dos centros de referências, como o da Coordenação de Aperfeiçoamento de Pessoal de Nível Superior (Capes). Ademais, os congressos também foram fundamentais para a coleta da produção recente, ainda não catalogada. Por fim, as indicações de pesquisadores na área completaram as eventuais faltas de trabalhos que ainda carecem de registro. Não poderia deixar de mencionar a importância da Biblioteca da Universidade Candido Mendes, a qual visitei nos anos de 2006 e 2007.
} 
enquanto forma, mas não se opondo às suas explicações gerais acerca da mobilização coletiva negra.

Contudo, uma insuficiência ainda permanece nessas pesquisas: a quase ausência de interlocução com as teorias da ação coletiva. Uma das conclusões a que cheguei ao término dessa incursão bibliográfica do primeiro capítulo foi a de que a maioria dos estudiosos não costuma trabalhar com as teorias contemporâneas dos movimentos sociais, reduzindo as pesquisas às descrições de caso. Na tentativa de contornar esta limitação, me aproximei dos teóricos mais influentes no campo acadêmico que trata da ação coletiva. Nessa investida, acabei por construir o segundo capítulo desta dissertação, intitulado "Da sociologia dos movimentos sociais à teoria da ação coletiva", com o fito de levantar algumas ferramentas conceituais e questões proeminentes na atualidade.

As problemáticas das principais correntes teóricas que versam sobre ação coletiva ajudaram-me a delimitar melhor meu objeto de estudo, que é a institucionalização do movimento negro brasileiro. Assim, para apreender esse processo, fiz um estudo de caso numa organização chamada Educafro - Educação e Cidadania para Afro-descendentes e Carentes -, que é uma das entidades mais influentes do movimento negro atual e que passou, a seu modo, por essa institucionalização, sobre a qual elaborei o capítulo terceiro da dissertação.

Para tanto, precisei recuperar a trajetória de sua principal liderança, bem como as ações desenvolvidas pelo grupo eclesial negro que ajudou a fundar a entidade. Essa empreitada foi realizada através de consulta bibliográfica e coleta de depoimentos já publicados, as quais receberam complementos com entrevistas que fiz para sanar eventuais dúvidas suscitadas no processo de confecção da dissertação. No que se refere ao grupo eclesial, tomei como referência principal o livro "'Ouvi o clamor desse povo'... negro", provavelmente, o documento mais influente do grupo nos anos da abertura democrática.

No que se refere exatamente à formação da Educafro, além da consulta aos trabalhos disponíveis sobre o assunto, realizei entrevistas, fiz consulta documental em processos jurídicos e cartas do arquivo da organização e servi-me de trajetórias de vida. Além disso, examinei cartazes, fotografias e jornais publicados pela entidade. Tornei-me, inclusive, estagiária da Educafro durante quatro meses, quando acompanhei os líderes, funcionários e estudantes em reuniões no 
Ministério Público, eventos nas universidades, entrevistas com a mídia, protestos nas ruas e, em especial, no dia-a-dia da instituição.

Para análise dos dados coletados, lancei mão de certas categorias da Teoria de Mobilização de Recursos, sobretudo para o exame das estratégias utilizadas pelos ativistas para captar recursos econômicos e arregimentar pessoas para o bom funcionamento da organização. Não menos importante foi a Teoria dos Novos Movimentos Sociais, para a qual a pergunta "como se forma a ação coletiva?" possui um sentido particular, pois envolve a construção da identidade do movimento, sem desconsiderar a subjetividade dos indivíduos engajados. Essa abordagem ajudou-me a examinar as trajetórias das lideranças, prestando atenção no elo que conecta o indivíduo à ação coletiva. De uma perspectiva estrutural, a Teoria do Processo Político (TPP) ajudou-me a pensar o ambiente externo à organização. No caso em relevo, as alianças políticas a Educafro com a Igreja, governantes, empresas de ensino superior e demais organizações e movimentos sociais. Desse modo, a TPP ofereceu-me instrumentos para examinar o modo pelo qual os atores coletivos avaliam e interpretam as oportunidades criadas pela abertura de estruturas políticas, econômicas e até mesmo religiosas.

Atenta para o fato de que um movimento social não se reduz às suas organizações, pois àquele se constitui por uma rede mais ampla que envolve os laços informais, escrevi o quarto capítulo, denominado "Protesto negro", porque queria analisar o movimento negro em conjunto, em ato. Tendo isso em vista, acompanhei as principais marchas negras dos últimos trinta anos. No decorrer desse tempo, foi possível identificar o caráter das transformações sofridas pelo movimento, em termos de suas alianças com outros agentes e grupos sociais, como os partidos políticos e, sobretudo, com os governos. Minha hipótese é de que as marchas recentes do movimento negro podem ser uma expressão da sua institucionalização, e não uma contra evidência desse processo. Explico-me: se no meu projeto de mestrado aventei a hipótese de que os protestos negros estariam cedendo lugar às rotinas burocráticas das organizações, 0 desenvolvimento da pesquisa parece mostrar o contrário: mesmo com a complexificação das entidades e com o aumento de órgãos burocráticos voltados para as demandas da comunidade negra (como conselhos, secretarias e pastas especiais) - o que garante maiores possibilidades de negociação das reivindicações de cunho racial -, os protestos de rua parecem coexistir tranqüilamente com esse novo jogo institucional. 
Para esse último capítulo, fiz consulta bibliográfica e análise de documentos emitidos pelo movimento, sobretudo para o caso das manifestações públicas das décadas de 1970 e 1980, como o ato de fundação do MNU e as marchas do Centenário da Abolição. Utilizei também as entrevistas de militantes já publicadas por Contins (2005) e Alberti e Pereira (2007) - que foram úteis, aliás, para os dois capítulos empíricos -, os quais levaram ao público os depoimentos de ativistas negros proeminentes na cena nacional. Enquanto Contins apresenta a trajetória das principais lideranças do Rio de Janeiro que protagonizaram as mobilizações de 1988; Alberti e Pereira mostram um panorama das lideranças negras das cinco regiões do território brasileiro. Alguns temas e recortes metodológicos são coincidentes, por exemplo, ambos os trabalhos interessam-se pelas experiências iniciais com o racismo, precisamente pelo momento da vida em que os entrevistados "sentiram na pele" a discriminação racial. Os dois livros de trajetórias investigam a participação dos ativistas nos protestos e em suas organizações, bem como seus envolvimentos com a política institucional, como em cargos administrativos e eletivos. Contins (2005) se ocupa, todavia, das estórias de vida, realçando as experiências subjetivas dos indivíduos, ao passo que Alberti e Pereira (2007) privilegiaram os aspectos estruturais das trajetórias dos atores, o que os tornam fontes complementares.

Além da consulta a esse material, realizei algumas entrevistas com as lideranças de manifestações públicas pouco documentadas, como a "Marcha Noturna pela Democracia Racial". Desta última, coletei os manifestos e os documentos das organizações que promovem esse evento. Além disso, recorri ao método etnográfico para registrar os símbolos, os discursos, os atores e as organizações das marchas ocorridas nos dois últimos anos. O método de análise documental também foi usado no estudo da Marcha do Tricentenário de Zumbi, para qual recorri, ademais, a registros fotográficos e audiovisuais. Esses são, em suma, os principais métodos e fontes para a elaboração do quarto capítulo.

Como foi o processo de institucionalização do movimento negro? Esta foi a pergunta que moveu a construção de meu projeto de mestrado e que persegui ao longo da dissertação. Nas considerações finais, procuro retomar essa questão, tentando relacioná-la à maior abertura democrática vivida pelo país. Desse modo, fecho a dissertação com um texto que busca tratar desse tema de forma mais abrangente, aproximando meu trabalho de campo das pesquisas contemporâneas que tangenciam esse assunto. 
Como se verá, essa institucionalização pode ser expressa em alguns elementos como a profissionalização dos militantes, a burocratização das organizações; a forma de recrutamento de pessoal e de mobilização de recursos, a especialização do ativismo, mormente no sentido dos protestos negros da atualidade. Em grande medida, essa institucionalização está ligada ao modo pelo qual o movimento se apropriou das oportunidades políticas oferecidas pelo Estado e pelo ambiente civil. Em outras palavras, ela está vinculada à questão que mais me intriga: o que tem sido o processo de democratização para o movimento negro brasileiro? 


\section{MOVIMENTO SOCIAL E RELAÇÕES RACIAIS}

\subsection{Introdução}

Em meio às grandes mobilizações civis dos anos setenta e oitenta, os cientistas sociais brasileiros foram surpreendidos com várias formas de ação coletiva provindas de diversos grupos, especialmente das camadas populares. Intrigados com a emergência desses segmentos na cena política nacional, Eder Saber e Maria Célia Paoli (2004 [1987]) revisitaram o pensamento sociológico, entre os anos de 1920 a 1980, procurando identificar o modo pelo qual tais grupos eram representados, sobretudo no tocante à mobilização política. Inspirada no trabalho desses autores, realizei uma investigação para o caso do movimento negro, mostrando como as Ciências Sociais abordaram a atuação desse grupo social, já que não havia trabalho parecido para o objeto em questão. Para tanto, contei, ainda, com dois estudos importantes que analisaram de forma consistente a produção sociológica das relações raciais do Brasil, quais sejam: Marcos Chor Maio (1997) e Antônio Sérgio Guimarães (1999).

Assim, este primeiro capítulo apresenta um exame dos estudos que trataram da mobilização negra, os quais são interpelados a partir de algumas questões-chave. Como a literatura sociológica explica e analisa o movimento negro? Quais são as abordagens teóricometodológicas dessa produção? O que mudou nas reflexões no que tange ao tratamento desse objeto?

Na primeira seção do capítulo, realizo um balanço bibliográfico dos estudos das relações raciais realizados entre os anos de 1940 a 1960. Com isso, desenhei um quadro acerca das explicações do surgimento, do perfil e da performance do movimento negro nas perspectivas diversas dos estudiosos que se debruçaram sobre esse tema. Para os autores, o movimento político de caráter racial surgiu no contexto de industrialização e modernização do Brasil, no início da formação da sociedade de classes, de modo que "ascensão social" e "preconceito de cor" são noções fundamentais para o entendimento da emergência da ação coletiva negra na primeira metade do século XX.

Na segunda seção do capítulo, examino a produção dos anos de 1970 em diante, quando houve um aumento dos estudos sobre o movimento negro, em contraste com o período anterior. Mas esse crescimento não está restrito ao âmbito quantitativo, notando-se uma mudança 
qualitativa, que carecia de exame detido e sistemático. Detenho-me apenas na produção que investigou essa questão nas últimas três décadas, por ser este o período que dialoga diretamente com meu problema de investigação empírica. Considerei importante, ainda, apresentar algumas críticas a essa produção, mostrando os limites das abordagens e apontado para outras perspectivas analíticas.

Em tempo, não posso deixar de notar que essa incursão demorada nos estudos sobre movimento negro influenciou decisivamente o caminho percorrido em minha dissertação, seja porque tentei evitar certos vícios de percurso, seja porque busquei compreender zonas marginalizadas pela literatura ou ainda porque sem tais estudos minha compreensão sobre o movimento negro estaria seriamente comprometida.

\subsection{Os estudos de relações raciais no Brasil: o caso da mobilização negra}

O que os estudos de relações raciais têm a nos dizer sobre a mobilização política do negro brasileiro? Essa pergunta pareceu-me pertinente para entender o modo como os pesquisadores explicaram a politização dos negros ao longo da primeira metade do século XX. Por conta disso, passo a recuperar os estudos sobre as relações entre negros e brancos no Brasil com a finalidade de averiguar o modo como essa temática apareceu na produção acadêmica, considerando que não seria possível tratar desse assunto sem situar as diferentes interpretações acerca do "padrão das relações de raças" no Brasil.

Se pudermos dizer que há uma tradição dos estudos de relações raciais ${ }^{2}$ neste país, certamente Brancos e Pretos na Bahia (1971[1942]), de Donald Pierson, estaria entre os primeiros trabalhos acadêmicos de caráter sistemático, com métodos de pesquisa mais próximos da chamada moderna Ciências Sociais. Pierson, estudante de doutorado do programa de Sociologia da Universidade de Chicago, veio ao Brasil na segunda metade da década de 1930

\footnotetext{
${ }^{2}$ Para Antônio Sérgio Guimarães (2004), Donald Pierson é o primeiro sociólogo a desenvolver estudos das relações raciais tal como esse campo sociológico foi designado pela Escola de Chicago. Antes, porém, Arthur Ramos já havia escrito ensaios, nos anos 30, sobre o negro e a política, os quais integram o livro "Negro na Civilização Brasileira". Nele, Ramos dedica dois ensaios para o estudo das mobilizações negras, um sobre a presença negra no movimento abolicionista e o segundo sobre as expressões do movimento negro de sua época, isto é, a Frente Negra Brasileira e os jornais negros. Os escritos de Ramos tinham como objetivo registrar os feitos dos negros na sociedade brasileira. Mesmo assim, deixa pistas de trabalho, muitas delas incorporadas e redefinidas pelos estudos realizados nos anos 50 .
} 
para realizar um "estudo de contacto racial". A Bahia foi escolhida como seu "laboratório" 3 de pesquisa, porque foi vista como uma sociedade em "estagnação social"; situação esta muito diferente daquela vivida por $\mathrm{Chicago}^{4}$, que estava em franca transformação. Assim, a sociedade baiana era uma espécie de teste de averiguação do caráter do preconceito racial, ou seja, se ele era observado em lugares em que os grupos raciais não estavam em competição aberta.

É bom lembrar, em breve parêntese, que a definição de preconceito racial, naquela época, vinha do também sociólogo de Chicago, Herbert Blumer ${ }^{5}$ (1958 [1939]), que o entendia como um sentido de posição social, ou um modo geral de orientação, que não pode ser reduzido a sentimentos ou crenças individuais, nem se limita ao status social, pois não está relacionado apenas à dimensão vertical. Ademais, para existir esse preconceito, seria indispensável a presença de quatro tipos básicos de disposições desenvolvidas pelos grupos dominantes: o sentimento de superioridade; a crença de que a raça subordinada está muito distante da realidade da raça dominante; o poder de controlar vantagens sociais; e o medo de que a raça subordinada busque alcançar os privilégios desfrutados pela camada dominante.

Tendo em vista essa formulação de Blumer, Donald Pierson, em seus estudos em Salvador, não encontrou "preconceito racial" - e quando ele se deparava com algum exemplo que se parecesse com isso, dizia que se tratava de algum vestígio de conflito de raças encontrado em certas situações esporádicas em que a raça fosse levada em conta, mas tais situações eram residuais e tenderiam a desaparecer. Segundo ele, naquela sociedade não havia grupos raciais fechados, mas, muito pelo contrário, eram grupos abertos de cor, nos quais cor e classe coincidiam; por conta disso, a cunhou de "sociedade multirracial de classes".

O estudo de Donald Pierson apontou para a inexistência de um problema político de caráter racial no Brasil. Suas conclusões foram extraídas tanto dos Congressos Afro-Brasileiros quanto dos depoimentos de brancos, pretos e mestiços. Nos dois congressos realizados, em 1930,

\footnotetext{
${ }^{3}$ A idéia de que o Brasil seria um "laboratório" já vinha de longa data. Rudingen Bilden (1929) já dizia que o Brasil era um laboratório digno de estudo, uma espécie de modelo de civilização para o mundo. Segundo Pallares Burke (2005), as idéias dele tiveram repercussão no mundo acadêmico americano.

${ }^{4}$ Os problemas sociais enfrentados por essa cidade influenciaram significativamente a formação da Escola Sociológica de Chicago, bem como as escolhas de seus objetos, temas e linhas de pesquisa. As questões referentes à luta por recursos e os conflitos dos grupos sociais foram largamente problematizadas nessa cidade, que vivia um crescente processo de desenvolvimento econômico e recebia muito migrantes, estrangeiros e nacionais. Sobre esse tema ver Bulmer (1985) e Eufrásio (1995).

5 Blumer opôs-se à definição de sua época, que via o preconceito racial como "um conjunto de sentimentos de membros de um grupo racial em relação a membros de outro grupo racial" (1958, p. 3).
} 
intelectuais tiveram grande interesse "pelos africanos e seus descendentes", mas os problemas tratados não eram aqueles "surgidos do atrito racial", argumenta o autor. Eles preocupavam-se com questões como "cultura negra" e suas tradições, sem diagnosticar qualquer questão referente ao problema político do contato entre as raças:

[aqui se referindo ao caso específico dos congressos afro-brasileiros] Faltou, em geral, qualquer preocupação pelos problemas de conflito racial ou de acomodação, o que indicava, bem definitivamente, a relativa ausência destes problemas na sociedade brasileira, bem como a relativa ausência de qualquer consciência de raça por parte dos pretos ou mestiços, ou de qualquer outro grupo, em reposta a esses problemas. (Grifo nosso, Pierson, 1974, p. 250).

Outras evidências levantadas por Pierson da falta de consciência de raça vieram dos discursos dos seus entrevistados, os quais diziam não haver um problema das raças no Brasil, especialmente quando comparado ao caso dos Estados Unidos: os negros e mestiços brasileiros em ascensão social não reclamavam de nenhum preconceito e os brancos diziam não se importar com a cor dos seus vizinhos ou colegas de trabalho; de outro lado, os negros, em condições desprivilegiadas, não atribuíam sua má fortuna a causas oriundas de preconceito racial, ao contrário, suas reclamações demonstravam insatisfação com a sua condição de pobreza. Com base nesses levantamentos, Pierson afirma que, de maneira geral, o país não chegou a desenvolver problemas raciais; mediante isso nem negros e nem brancos possuíam "consciência de raça". Ressalte-se que a fluidez das formas de classificação racial no Brasil era também assinalada como um fator determinante da ausência de consciência racial, seja do grupo dominante, seja do grupo subordinado.

Franklin Frazier (1942), outro sociólogo de Chicago, sustenta uma argumentação um tanto quanto distinta de Pierson. Frazier concorda com Pierson no tocante à ausência de preconceito racial no Brasil, tal como se verificava nos EUA. Mas o autor entendia que no Brasil havia o preconceito de cor, baseado não na ascendência do indivíduo e sim nas suas características físicas. "Yet, there is in Brazil a certain amount of color prejudice, which should be distinguished from race prejudice in the American sense" (Frazier, 1942, p. 292). Esse preconceito de cor poderia ser identificado no sul do Brasil, devido à presença de imigrantes europeus, sobretudo italianos que, além de possuírem uma mentalidade diferente dos portugueses, estavam em franca competição com os negros. Embora não tivesse feito estudos 
aprofundados como Pierson fizera na Bahia, Frazier teve a oportunidade de conversar com algumas lideranças negras, especialmente da Frente Negra Brasileira, do qual extraiu reclamações de atitudes preconceituosas contra os negros. Com base nessas informações, esse estudioso sugeriu a existência de preconceito contra os negros, mas este seria baseado na cor e não poderia ser generalizado para todo o país.

Ao que parece, a suspeita de Frazier ganha força com os resultados dos estudos da Unesco, nos anos 50; no entanto, isso só é verdade para as pesquisas que investigaram as regiões do sudeste e do sul do Brasil (Guimarães, 1999). Thales de Azevedo (1996 [1953]), por exemplo, foi um dos estudiosos que não abandonou a tese de Donald Pierson ${ }^{6}$, porém a visão acerca da sociedade baiana sofreu alguma modificação sob as lentes do autor de As elites de cor numa cidade brasileira.

Para Thales de Azevedo, a cidade de Salvador poderia até ser uma "sociedade multirracial de classes", como propôs Pierson, mas essas classes não eram "verdadeiras", por conta da "persistência do sistema de status" que reduzia "as aspirações individuais", fazendo com que a mobilidade dos negros fosse "freada pelo status de nascimento e pela cor" (Azevedo, 1996, p.178). Todavia, na dinâmica das relações raciais baianas, os entraves ao avanço do negro na hierarquia social poderiam ser driblados por um conjunto de mecanismos, como o casamento inter-racial, a instrução, os bons relacionamentos, o emprego público etc. Assim, os entraves "se deixariam modificar, até certo ponto, pela fortuna, pela ocupação e pela educação” (idem, p.179).

Num capítulo chamado "Os movimentos negros na Bahia", esse autor descreve sucintamente como surgiram as primeiras organizações de "gente preta" que lutavam contra o preconceito de cor. As associações e coletividades de "pessoas escuras" não eram novidades para os baianos, já que as "irmandades religiosas e algumas associações operárias e beneficentes" se faziam presente bem antes da formação desse novo perfil de organização política. $O$ fato era que as entidades antigas não "tinham a finalidade expressa de defesa das pessoas de cor contra os preconceitos raciais" (Azevedo, 1996, p.157).

\footnotetext{
${ }^{6}$ Marvin Harris foi outro pesquisador das relações raciais no Brasil, que, assim como Thales de Azevedo, estava sob o referencial de Pierson. As formas de classificação e os estereótipos raciais brasileiros foram largamente utilizados por este autor que teve como interesse de estudo as regiões rurais deste país (Maio, 1997). Harris, em Padrões raciais nas Américas (1967), descreve o Brasil assim: “(...) as raças não existem para os brasileiros. Mas as classes existem tanto para o observador quanto para os brasileiros. Este é o primeiro fato a ser assimilado se a curiosidade nos aguça quanto à razão pela qual a identidade racial em si mesma é coisa sutil e de pouca monta no Brasil, enquanto que nos Estados Unidos, é para milhões de pessoas um passaporte para o inferno" (Harris, 1967, p.101).
} 
Azevedo afirma que a primeira mobilização coletiva com objetivo de lutar contra o preconceito racial veio da Frente Negra Brasileira, que chegou na Bahia em 1932 pelas mãos de "um grupo de menos de 10 homens modestos de cor", consolidando um movimento de expansão dessa organização fundada em São Paulo um ano antes. Embora ele não investigue a fundo a Frente Negra em Salvador, chama a atenção o modo como é feita a descrição da Frente Negra Paulista: “(...) quando o proletariado urbano brasileiro começou a ganhar consciência da sua existência, como grupo, surgiu no sul do país um movimento destinado a agrupar "a gente negra brasileira" (Azevedo, 1996, p.185). Pelo visto, ele sugere que a formação de movimento negro contra o preconceito de cor surge no mesmo contexto da formação de uma consciência dos operários enquanto grupo. Mas seu argumento não avança mais do que isso, não sendo possível inferir se o autor estabelecia um tipo mais profundo de relação entre uma experiência social do tipo de classe com organização política dos homens de cor.

A Frente Negra Baiana, para um informante de Thales de Azevedo, nasceu fadada ao fracasso e isso foi confirmado pelo autor através da opinião pública local. A imprensa acreditava na ausência do preconceito racial e tinha medo de que essa organização negra pudesse trazer o preconceito racial e acirrá-lo entre os baianos. Já seus informantes, aqueles pertencentes às chamadas elites de cor, achavam desnecessária a presença de tal movimento na Bahia. No entendimento de Thales de Azevedo, o tom de revolta das ações da Frente Negra estava em descompasso como a representação das elites de cor baianas.

Além da Frente Negra na Bahia, a Sociedade Henrique Dias e a associação Pi Racial foram arroladas por Azevedo na composição do quadro daquilo que ele chamou de movimentos negros. Contudo, nenhuma delas conseguiu adquirir muito sucesso em Salvador, seja pelo "temor de que os movimentos negros no Brasil assumam tendências segregadoras", seja pelas "dificuldades do preto da Bahia" se convencer de que é preto, como salientou um militante negro entrevistado por Thales de Azevedo.

Pelo visto, Azevedo descreve o surgimento do movimento negro na Bahia, mostrando suas dificuldades de penetração na opinião pública local. A baixa adesão das elites pretas e mestiças e as opiniões contrárias das "elites brancas" foram os principais empecimentos para o sucesso das organizações negras. Isso porque para o baiano não existia um problema racial, já que "a consciência de classe supera[va] a consciência de cor ou de raça" (Idem, p.62). 
Já nos outros estudos realizados nas regiões do sudeste do Brasil, esse problema configura-se de outra maneira. Neles, o problema da "consciência de raça" aparece em outros termos. Tal é o caso do sociólogo Costa Pinto (1953) que, ao realizar o primeiro estudo das relações raciais no Rio de Janeiro (Maio, 1997), considerou pertinente pesquisar o movimento social organizado por negros. Para o autor, as pesquisas de relações raciais também deveriam voltar-se para o estudo das "associações negras e suas lideranças", bem como para a função desempenhada por elas no âmbito das relações entre negros e brancos. Nesse sentido, as mudanças ocorridas no Brasil são tidas como fundamentais para explicar o aparecimento de tais movimentos, mesmo porque a chamada consciência de raça ou étnica - tomadas como sinônimos por Costa Pinto - resultaria de uma experiência social e econômica dos negros no seio de uma sociedade em transformação.

Para Costa Pinto, se o "quadro tradicional das relações de raças" favoreceram à formação de associações com finalidades religiosas e recreativas, a exemplo das irmandades; as transformações sociais alterariam esse quadro, levando a diferenciação econômica, social e cultural que passa a ser visível no seio da população negra: de um lado, "os estratos de elite, formados por negros mestiços e evoluídos" (idem, p.237), de outro, "o negro massa". Diferenciação esta vista como fruto do processo de industrialização, da proletarização da população negra e do processo de ascensão social de uma pequena camada negra, a qual traz certas exigências e aspirações sociais. Um dos achados mais significativos desse autor diz respeito à maneira como ele relaciona essa diferenciação à emergência de movimentos sociais:

O fator essencial dessa tomada de consciência é representado pela resistência dos extratos brancos superiores em aceitar essa mobilidade ascencional no negro evoluído, resistência que cresceu na medida em que a ascensão deixou de ser estritamente individual e passou a ser social. Sendo raciais as barreiras encontradas, esse grupo teve de tomar consciência delas em termos também raciais e, assim, lutar contra elas em movimentos raciais (Costa Pinto, 1953, p. 332).

Essa passagem sintetiza bem a tese central da argumentação do autor. Os negros em processo de ascensão perceberam, mediante a experiência do preconceito racial, que suas chances sociais eram limitadas pela resistência das elites brancas. Essa "vivência do problema se transforma em consciência dele" (idem, p.232). A consciência é vista como uma espécie de combustível para dar partida à formação das associações de novo tipo, "encaradas [pelo autor] 
como a tomada de consciência, mais ou menos nítida, mais ou menos deformada, da irresolução dos problemas relativos aos seus interesses materiais, seu status, seus valores, suas aspirações e suas perspectivas" (idem, p.231). Nesse sentido, os movimentos de cunho racial não passavam de uma "elite intelectualizada" que se apresentava como uma vanguarda de um grupo social que encontrava dificuldades e empecilho para ascender-se socialmente. Tal elite teria expressado essas dificuldades em termos étnicos, sendo que as associações negras visavam

satisfazer as suas necessidades artísticas, intelectuais, esportivas e outras de natureza recreativa e para lutar declaradamente contra os obstáculos materiais e preconceituais (sic) que encontra ao seu desenvolvimento e participação e ascensão plena (Costa Pinto, p. 237-238).

Assim, Costa Pinto, ao fazer suas considerações acerca das práticas e ideologias do movimento negro, estava voltado particularmente para a experiência do Teatro Experimental do Negro (TEN) e seus intelectuais, dentre eles Abdias do Nascimento e Guerreiro Ramos ${ }^{7}$. A partir do TEN, a "ideologia da negritude" é vista como a "forma mais sofisticada e elaborada dessa consciência de raça no Brasil” (Idem, p.333), além de ser uma bandeira de ascensão social. E ele vai mais além: essa consciência étnica não vem do negro, porque deseja construir uma identidade para si mesmo. Não se trata disso. Nos termos de Costa Pinto, o "negro pequeno-burguês" se vê forçado a desenvolver uma consciência étnica (Idem, p.333). Tudo se passa como se a ideologia da negritude fosse uma espécie de aspiração do negro de classe média, seu desejo de ascensão social. Esta elite buscaria esquecer que era negra, caso não encontrasse em seu processo de ascensão barreiras baseadas em fatores raciais.

Esse autor defende que o movimento de negritude não passaria de uma "falsa consciência”, porque no fundo esse problema não seria étnico, e sim o resultado das contradições sociais mais amplas. De modo que as prioridades das lideranças negras não encontram respaldo nas aspirações do homem de cor comum, o "homem povo", "o homem proletário". Essa argumentação de Costa Pinto estava em consonância com as análises feitas por outros estudiosos das relações raciais daquele período.

\footnotetext{
${ }^{7}$ Muryatan Barbosa (2004) assinala o debate travado entre Costa Pinto e Guerreiro Ramos. Ao que parece, Costa Pinto tinha uma visão um tanto quanto superficial da negritude. Barbosa também apresenta, no capítulo "A integração ao TEN", como o tema da negritude passa a ser trabalhado pela intelectualidade negra brasileira.
} 
Roger Bastide (1973 [1951]), quando analisa a Imprensa Negra do Estado de São Paulo ${ }^{8}$, utiliza-se de formulações que de certa forma concordam com explicações de Costa Pinto; porém há naquele uma reflexão diferenciada no que se refere ao entendimento do caráter do protesto negro. Seu diferencial talvez esteja no modo como ele aborda o problema. Preocupado com as representações coletivas dos negros organizados, o sociólogo francês abre um leque mais rico de dimensões acerca das aspirações desse grupo social, ao mesmo tempo em que revela as dimensões sócio-culturais que são negadas pelos negros organizados.

Como a preocupação de Bastide é entender as representações coletivas desse grupo, os jornais negros apresentam-se como o lócus privilegiado de análise. A imprensa negra é vista como uma forma de protesto por princípio, porque ela só existe devido à presença do preconceito de cor na sociedade, ou melhor: quando há uma percepção ou um entendimento por parte do grupo dominado acerca da existência do preconceito de cor. Os negros que percebem esse preconceito compõem a pequena classe média negra (são professores, advogados, jornalistas, revisores de provas tipográficas), que não estariam distante das camadas pobres das quais se originaram, pois sua ascensão era relativamente recente. Por isso, o autor entende que os negros representados na imprensa negra refletiam muito mais que a opinião de extratos médios:

há pouco saída de uma classe baixa,[a classe média negra] conhece os desejos e as misérias dela na realidade, tomou consciência do que não é ainda claro ou muito sentido pelos seus irmãos de nível baixo, tornou-se eco de toda uma classe de cor (Bastide,1973, p.130).

Bastide encontra, na imprensa negra, queixas dos homens de cor em diferentes campos da vida social, notadamente no mercado de trabalho e na vida cultural. São reclamações contra o tratamento diferenciado para negros, marcadamente as dificuldades de serem aceitos em festas, clubes, agremiações, sociedades de beneficência, dentre outros espaços sociais. O fato é que o preconceito era sentido pelos indivíduos e expresso nos jornais:

mas o que é fato é que o preto, com ou sem razão, sente que sua ascensão na escala social é perturbada pela existência de tal preconceito. Portanto, como representação coletiva do negro, o preconceito inegavelmente existe é isso que nos importa (Bastide, 1973, p. 137).

\footnotetext{
${ }^{8} \mathrm{O}$ estudo de Bastide sobre a imprensa negra foi realizado no início da década de 50; sua primeira edição data de 1951, com o título “A Imprensa Negra do Estado de São Paulo", publicada no Boletim da Faculdade de Filosofia da Universidade de São Paulo, vol. CXXI, n. 2, p. 50-78.
} 
Com esse conteúdo, o significado da imprensa negra extrapolava os limites de um empreendimento comum: tratava-se da construção de uma ação coletiva organizada por negros de classe média, cujo objetivo era a denúncia do preconceito de cor.

Assim como Bastide, Oracy Nogueira identificou que o preconceito racial ${ }^{9}$ atuava de forma distinta entre as camadas sociais. Os extratos menos desfavorecidos tendiam à acomodação "espontânea", "uma vez que, com maior probabilidade, se disfarçará o preconceito de cor, pela sua associação com o de classe" (Idem, p. 197). Caso diferente acontecia no processo de ascensão social do negro, tendo em vista que o preconceito incidia objetivamente como “obstáculo que se lhe opõem à mobilidade social” (Idem, 198).

Os efeitos do preconceito de cor fizeram-se notar na criação de clubes sociais de negros, mas esses não levaram à formação de associações políticas, tal como visto na cidade de São Paulo. No caso específico de Itapetininga, o autor evitou falar de movimento negro, tal como teria sido apresentado por Thales de Azevedo e Costa Pinto em seus estudos. Essa reserva de Oracy Nogueira talvez tenha se dado porque "as associações de gente de cor" da cidade estudada não desenvolvia atividades de questionamento da situação racial, não havendo nenhum tipo de "manifestação de protesto". Os objetivos delas eram tão-somente atividades recreativas e de lazer, além de fins educativos, como organização de uma biblioteca. A existência dessas associações, na interpretação do autor, revelava que os negros não eram bem recebidos nos outros clubes recreativos da cidade e, portanto, se viram na situação de construir espaços onde pudessem ter uma vida associativa, longe do preconceito de cor.

\footnotetext{
${ }^{9}$ Diferentemente de Costa Pinto e de Roger Bastide, Nogueira não fez sua pesquisa nas grandes capitais da região sudeste, ela foi desenvolvida numa cidade do interior do Estado de São Paulo. Seu estudo de comunidade realizado no município de Itapetininga "colocou a sociedade brasileira no microscópio" (Maio, 1997, p.174), tornando-se um caso exemplar para os estudos de relações raciais, isso porque "Nogueira desafiando as lições de Herbert Blumer (1939 e 1958) e de seu mestre Donald Pierson (1971[1942]) teorizava uma nova forma de preconceito racial, presente em sociedade como o Brasil" (Guimarães, 1999, p.169). A partir desse trabalho, ele estabeleceu que o preconceito racial do Brasil era de um tipo específico, chamado de preconceito de marca, em oposição ao preconceito de origem presente na sociedade norte-americana. Enquanto o primeiro abarcava as ambigüidades do sistema classificatório brasileiro, tomando a aparência racial do indivíduo; o segundo tipo de preconceito racial, o de origem, tomava a ascendência como critério de exclusão social. Segundo ele, o preconceito de marca "tende, antes, a situar os indivíduos, uns em relação aos outros, ao longo de um continuum que vai de extremamente "negróide", de um lado, ao extremamente "caucasóide", de outro (Nogueira, 1998 [1955], p.199). Desse modo, os aspectos físicos e estéticos, como a densidade de pigmentação, a textura dos cabelos e o formato dos nariz e dos lábios são determinantes para se discriminar ou não um individuo.
} 
Todavia, o autor suspeitava que a passagem da sociedade tradicional para a industrial levaria à intensificação da "consciência de classe". Nesse sentido, ele apresentou em forma de hipótese a possibilidade de uma mudança no âmbito da ideologia racial, fazendo com que a ascensão do negro deixasse de ser individual para se tornar "ideologia de reivindicação de massas". Assim, o autor via a possibilidade de que o preconceito atuasse "como um propulsor da integração dos elementos de cor na luta de classes" (Idem, p.201). Oracy Nogueira não era o único a pensar nesses termos. Podemos dizer que Florestan Fernandes leva a cabo essa hipótese no livro A Integração do Negro na Sociedade de Classes, mas antes de chegarmos a ele, veremos os primeiros escritos de Fernandes acerca dos movimentos negros na cidade de São Paulo.

Em Fernandes, é possível ver a montagem de um quadro mais abrangente e rico de detalhes na construção do problema sociológico em torno do movimento negro. Em outras palavras, ele consegue estabelecer relações mais consistentes entre mudanças estruturais e ação coletiva de grupos organizados. Já em seu primeiro estudo sobre as relações raciais no Brasil, Florestan Fernandes (1955) busca explicações para a mobilização negra. O que são os movimentos sociais negros? Como eles surgem? Qual a sua função? São indagações que ele procura responder numa de suas primeiras análises sobre a politização dos grupos raciais em São Paulo.

Suas conclusões são de que os movimentos sociais no "meio negro" são reações ao "preconceito de cor", confirmando assim as análises de seus contemporâneos. Para Fernandes, tais movimentos teriam as seguintes funções sociais: o ganho de autonomia em relação aos brancos, a construção de laços de solidariedade entre os negros e a "consciência social de interesses comuns", cortando os velhos laços tradicionais de dependência entre negros e brancos. Ademais, Fernandes via, por intermédio dos movimentos, a possibilidade de superação do sentimento de inferioridade vivido pelos indivíduos negros.

Em decorrência disso, esses movimentos sociais tinham a função de promover a integração plena do negro "no regime de trabalho livre e no sistema de classes" (Fernandes, 1955, p. 203), entendendo que a própria população de cor deveria ser educada através da elevação moral, do aumento do nível de escolaridade, de maior coesão familiar, do controle dos vícios. Era necessária a criação de condições psico-sociais para o negro, o que envolveria a disciplina e moralidade condizente ao sistema capitalista. 
No modelo estrutural-funcionalista de Florestan Fernandes, as causas para a emergência do protesto negro têm motivações econômicas. Note-se que, para ele, os homens de cor até os anos 30 não foram mais do que marginais na "nossa revolução burguesa", sequer se tornaram proletários. A grande massa negra estava completamente fora da sociedade de classes até esse período, o que fica mais evidente em sua tese A Integração do Negro na Sociedade de Classes (1964). Nela, o autor retoma todas as explicações apresentadas nas análises feitas no capítulo “A luta contra o preconceito de Cor" de 1955. No tocante aos movimentos negros, o que há de novo é a densidade e a larga fundamentação empírica encontradas nos escritos de 1964, cujas fontes principais são os jornais da imprensa negra e o estudo da Frente Negra Brasileira (1931-1937).

Em A Integração do Negro, Fernandes defende que "as transformações histórico-sociais" passaram ao largo das mudanças da ordem das relações entre negros e brancos, herdada do regime escravista. Isso porque a sociabilidade desses grupos ainda era mediada por relações construídas na escravidão, apesar do franco crescimento econômico da cidade e da mudança de regime de trabalho, de modo que, na sociedade competitiva, dois dilemas precisavam ser enfrentados: a integração efetiva do negro na sociedade de classes e a superação do preconceito de cor.

Diante desses dois grandes dilemas para a efetivação da modernidade na sociedade paulistana, Florestan Fernandes atribui aos movimentos sociais que se insurgem contra o "preconceito de cor" o papel de agente modernizador das relações raciais dessa sociedade. Tratava-se, contudo, de uma "revolução dentro da ordem" a qual os grupos negros organizados tomaram para si a incumbência histórica de revelar "as contradições existentes entre o substrato legal e a realidade social”. Desse modo, a mobilização negra buscaria a integração da população de cor, e não uma mudança radical das bases sociais e econômicas da sociedade. Esse movimento tinha, assim, como objetivo estabelecer "uma situação de classe" em oposição ao regime de castas herdado da sociedade escravista. Destarte, a ação coletiva negra, para Fernandes, consolidaria um "estilo democrático de vida".

Como apresentado nos escritos de 1955, as explicações de Fernandes para o surgimento dos movimentos negros no Brasil são de ordem macro-estrutural: a pauperização da população de cor, bem como o desejo da camada dominante em manter as antigas posições sociais. Mas, à medida que a cidade de São Paulo passava por uma forte industrialização, ocorreram também 
mudanças tanto nas camadas populares quanto nas camadas de elite: as primeiras passam por um "processo de proletarização", tornando-se operários, ao passo que as camadas dirigentes já não podiam mais agir segundo os padrões autoritários sem qualquer possibilidade de contestação. Nesta estrutura, o conflito aparece de outro modo e as reivindicações dos grupos proletários passam a ganhar espaço. Este era, pois, um contexto propício para emergência de grupos contestatórios e também para o questionamento da "forma tradicional de acomodação e de dominação raciais". Em meio a tais mudanças, o negro também passa a debater o "problema racial".

Assim, surgiria uma "consciência racional" do negro, ou seja, a percepção da sua condição social e a necessidade de elaboração de uma ação coletiva capaz de mudar as condições sociais relegadas a esse segmento. Como se pôde ver, as principais idéias presentes no livro $A$ Integração do Negro foram aprofundadas e recheadas de dados históricos e sociológicos acerca da realidade do negro em São Paulo.

No que diz respeito ao problema da ascensão social como fator de explicação para a emergência de uma consciência racial, Fernandes defende que, nesse período de transformação, a ascensão social tinha um significado um pouco distinto do período de dominação racial tradicional, na qual os que se viam como elite rompiam suas ligações com pessoas de camadas mais baixas. Entretanto, com o rompimento da ordem patrimonialista, essas relações sofreram algumas alterações, especialmente no tocante à constituição de laços de solidariedade entre os negros. As elites negras desenvolveram uma real consciência da sua realidade social e tiveram uma atitude de aproximação da população de cor. Contudo, Fernandes nota as dificuldades de aceitação desses discursos por parte da grande massa negra, mas isso teve como causa a sua situação de apatia social, e não o descompasso de interesses entre camadas de elite e camadas baixas negras.

Mesmo com os esforços dos movimentos negros, a sociedade não apresentou mudanças substantivas no que se refere à representação social e ao tratamento do negro. Os protestos não foram suficientemente capazes de alterar a ordem social; somente com o processo crescente de industrialização em São Paulo depois da Segunda Guerra Mundial que houve o ingresso dos negros em vários ramos do trabalho assalariado, apesar da persistência do preconceito de cor. Mas o negro não entra como grupo social, e sim como "massa de agentes" que constituíam a 
mão-de-obra livre ${ }^{10}$, estabelecendo uma ordem mais competitiva na qual os movimentos coletivos foram enfraquecidos e as estratégias individuais intensificadas.

Esgotava-se, então, toda a fonte de protesto racial em São Paulo. Os objetivos dos movimentos negros foram alcançados em partes, mas não pelos seus esforços: tratava-se de um processo maior, para além de suas forças e alcances, que fazia cumprir aquilo que os protestos tanto exigiam. Era a integração do negro na força de trabalho como mão-de-obra assalariada, uma mudança ascensional da situação de desempregado e biscateiro para a posição mais estável, seja como trabalhador assalariado, ou como proletário. Tudo se passa como se a camada média negra perdesse o motivo maior pelo qual deveria lutar. Assim, para Fernandes, a emergência e o declínio do movimento negro devem-se a mudanças estruturais da sociedade, restritas quase que unicamente à ordem econômica.

\subsection{Um breve balanço}

As primeiras investigações sociológicas sobre o movimento negro brasileiro aparecem nos estudos de relações raciais, especificamente em algumas pesquisas da UNESCO. As formas diversas de interpretação desse movimento social estão diretamente ligadas à visão que os autores tinham das relações entre negros e brancos no Brasil. Enquanto as conclusões das primeiras pesquisas dos anos de 1940 negavam a existência de preconceito racial nesse país, os trabalhos posteriores, sobretudo dos anos de 1950 e de 1960, indicavam que havia, sim, uma forma particular de preconceito, teorizada por Oracy Nogueira.

Se Pierson defendia a ausência de consciência racial no Brasil era porque identificava a existência de grupos abertos, que não se apegavam a preconceitos raciais. Nem pretos nem brancos viam-se como grupos fechados, por isso a inexistência de "consciência de raça" e, por conseguinte, de grupos políticos direcionados a essa questão. $\mathrm{O}$ critério racial não determinava destino social dos negros e isso era especialmente visto no processo de ascensão dos mestiços baianos. Os "homens de cor" em mobilidade ascendente não se viam como grupos raciais, nem

\footnotetext{
10 "A cidade, que não ouvira o clamor de seu protesto e permanecera indiferente a seus sonhos de igualdade racial, abre-lhes algumas trilhas que simplificavam e atendiam aos seus anseios de classificação no núcleo da ordem social legítima. Assim, o negro penetra, não em um grupo ou como categoria racial, mas diluído na massa de agentes do trabalho assalariado em todos os ramos de atividades" (Idem, p.118)
} 
percebiam qualquer tipo de empecilho ao longo de sua vida profissional. Além do mais, os brancos sequer se sentiam incomodados, quanto menos ameaçados pelos negros, o que impossibilitava a emergência de uma consciência de raça entre aqueles. Como conseqüência: nenhum dos dois se representava como grupo racial.

Apesar de perceber as nuanças das classes e dos grupos de cor na cidade de Salvador, Thales de Azevedo não se afastou das conclusões de Pierson no tocante à ausência de consciência racial entre os soteropolitanos, apesar de ter identificado mobilização negra organizada na capital baiana. Em contraste, Oracy Nogueira, observando uma cidade do interior de São Paulo, não só teorizou a foram de preconceito racial da sociedade brasileira, mas também identificou nos seus entrevistados a percepção da existência do preconceito de cor. Entretanto, em Itapetininga, não fora verificado nenhum tipo de ação coletiva cujo objetivo fosse o combate desse tipo de problema.

Já Costa Pinto, Roger Bastide e Florestan Fernandes apresentam visões diferentes das de Donald Pierson. Diferentemente deste, aqueles diagnosticavam a existência de preconceito de cor no Brasil, fundamentalmente nas áreas em processo de grande transformação econômica. Ademais, os três autores tiveram a oportunidade de estudar associações negras das cidades do Rio de Janeiro e de São Paulo. Para eles, o movimento negro surge das mudanças macro-estruturais vividas em sociedades que passaram por intensas alterações sócio-econômicas. Suas explicações são convergentes, guardando muitas ressalvas no tocante às interpretações sociológicas e aos pontos nos quais cada um decidiu dar mais ênfase.

Costa Pinto e Bastide enfatizaram o processo de diferenciação no interior da população de cor, o que os possibilitou observar as aspirações e interesses específicos das camadas médias e baixas negras. Suas análises permitiram a ambos uma explicação coerente para as dificuldades do protesto negro em se fazer ecoar entre as camadas mais baixas. Porém, Bastide, mais voltado para as representações sociais à moda da sociologia francesa herdeira de Durkheim, conseguiu dimensionar melhor as posições econômicas, a origem social e as aspirações das camadas médias formadoras do movimento negro.

Mas, há que se considerar que tanto Bastide quanto Costa Pinto apresentam uma explicação parecida para a emergência de ação coletiva dos negros, que viria a desembocar nas formas associativas modernas, tal como a imprensa negra e as associações de novo tipo, esta 
última para ficar com a terminologia de Costa Pinto. Essa explicação baseia-se na formação de uma classe média negra e sua dificuldade em ascender socialmente. Eis aí a explicação para a emergência de um sentimento coletivo de insatisfação, imprescindível para a formação do movimento organizado cujos suportes seriam as associações negras de novo tipo.

Porém, Costa Pinto, numa perspectiva marxista, assinalava que os interesses das lideranças negras que bradavam contra o preconceito de cor construíram uma falsa consciência de raça. Não que não houvesse o tal preconceito, este existia e era sentido pelos negros. $\mathrm{O}$ problema, para o sociólogo, não estava aí, e sim na aceitação de uma ideologia racial que buscava elevar e "adestrar" a massa negra em um estilo de vida de classe média. Esses objetivos não respondiam às aspirações das camadas pobres, eram apenas desejos das camadas médias negras, com seus interesses particulares de classe. Por isso, era falsa a consciência racial do movimento negro.

Fernandes tinha uma visão diferente. Em seu entendimento, a consciência racial do negro passou por uma experiência "existencial" do preconceito de cor. Era mesmo uma camada diferenciada da população negra que liderava os movimentos; no entanto, essa camada procurava educar a sociedade, negros e brancos, para o problema do preconceito, cujos efeitos se faziam notar não somente na dificuldade de ascensão social dos negros "instruídos", mas, sobretudo, na situação de penúria vivida pela população negra que ainda não tinha se inserido na sociedade de classes. Em suma, essa consciência racional de raças, canalizada em forma de protesto, teria tornado o negro em agente de sua própria história, autônomo e coletivamente organizado frente às relações tradicionais de dominação racial. Com efeito, os discursos e reivindicações do movimento negro ecoaram nas análises de Fernandes, o qual, dentre todos os autores desse período, foi o que mais compartilhou com as idéias do grupo estudado.

Por fim, saliente-se aqui uma contribuição fundamental desses estudos das relações raciais brasileiras para o entendimento da emergência e do caráter do protesto racial negro no Brasil: a relação entre as classes médias negras e a ação coletiva de cunho racial. A despeito das diferentes interpretações acerca dos objetivos e ideologias dos movimentos negros da primeira metade do século XX, os autores que estudaram as reivindicações negras descobriram que não é possível entender o movimento negro daquele período sem mirar para uma camada média de negros que se vê barrada pelo processo de preconceito de cor. Nesse caso, "ascensão social" e "preconceito 
de cor", bem como "classe" e "raça" entrelaçaram-se numa relação complexa nas análises sobre o movimento negro no Brasil. Assim, encerra-se um ciclo de estudos, cujas explicações se orientam por abordagens macro-estruturais com viés econômico.

\subsection{Novos estudos sobre movimento negro}

O movimento social negro que ressurge nos anos 70 mudou suas feições, aliás a produção acadêmica também se modificou. Diferentemente da abordagem que encerra os estudos das relações raciais dos anos 60, os estudos das décadas seguintes possuem novas questões e novas perspectivas. A maior parte desta produção se pensa como revisões críticas dos estudos das relações raciais, especialmente no tocante ao movimento negro. E o são em alguma medida. Todavia, o que esses pesquisadores não dizem - o que torna suas interlocuções mais instigantes é que muitos dos problemas postos para a geração anterior são incorporados e recolocados no debate desta geração de estudos emergente.

Mas, é preciso tratar essa questão com mais vagar. Essa mudança não ocorreu de qualquer maneira nem de forma abrupta, antes as modificações vão aparecendo aos poucos, tornando-se mais efetivas e consolidadas na medida em que as ações do movimento social tornam-se mais concretas, mais visíveis; e isso leva quase uma década para ser incorporado pela literatura. $\mathrm{O}$ impacto das ações dos movimentos sociais sobre a produção acadêmica aconteceu de vários modos, desde os temas e as abordagens até os próprios pesquisadores.

O primeiro aspecto digno de nota é o perfil dos estudiosos. Quem são eles? O que mais chama a atenção nessa produção é o fato dos negros deslocarem-se do lugar de informantes dos pesquisadores estabelecidos para a posição de ensaístas e intelectuais. Se antes aqueles eram citados em teses de Roger Bastide, Florestan Fernandes e Costa Pinto, essa nova intelectualidade escreve sobre a mobilização negra em que estão inseridos. Eis um dado curioso: os estudos que engrossam a produção sobre movimentos negros a partir dos anos 70 são feitos, em grande medida, por estudiosos negros. Isso não foge, pois, a uma tendência da geração desse período: muitos militantes e simpatizantes de movimentos sociais tornam-se pesquisadores dessa forma de ação coletiva, como foi muito bem notado por Cardoso (1989) e Gohn (2004), em comentários críticos à produção acadêmica sobre esse tema. Mas essa realidade, torna-se mais vívida nos anos 80 em diante, pois na década anterior ainda podemos verificar uma transição, um momento 
ainda mesclado pelos padrões de pesquisadores e perspectivas analíticas antigos, juntamente com as novas tendências tidas como críticas que ameaçavam aparecer.

Esse é um dado importante para ser considerado na revisão dessa literatura. De modo que não é possível estudá-la sem saber quem são esses estudiosos, quais os seus problemas de pesquisa e como interpelam o objeto e a produção acadêmica sobre o movimento negro brasileiro.

Em termos de abordagem analítica, houve uma passagem da terminologia "consciência racial" para "identidade racial ou étnica". Note-se que essa mudança não ocorreu de uma forma rápida e definitiva. A expressão "consciência racial" continuava a ser acionada, mas o conceito de identidade ganhava cada vez mais proeminência. Isso ocorre, sobretudo, por conta do avanço dos estudos antropológicos sobre esse campo e a crescente rejeição às categorias marxistas para explicar os movimentos sociais, o que se faz notar também em suas referências bibliográficas. Com isso, as abordagens ganham feições mais culturalistas, porém sem descartar as dimensões políticas.

Nos anos de 1970, três autores trataram sob perspectivas diversas a questão da mobilização política no veio do protesto racial brasileiro. Primeiramente, aparece o artigo de Queiroz em cuja argumentação não encontramos rupturas com as formas de explicação vindas de seus antecessores, especialmente dos de São Paulo e do Rio de Janeiro.

Maria Isaura Pereira de Queiroz (1978 [1974]), no ensaio “Coletividades negras: ascensão sócio-econômica dos negros no Brasil e em São Paulo", investiga as "associações voluntárias" dos negros, porque estas seriam canais de acesso à "consciência coletiva" desse grupo social. Nele, Queiroz contentou-se em tratar de forma mais explícita da relação entre ascensão e mobilização política, sendo que toda fundamentação de seu argumento teve como fonte as conclusões de Fernandes, Bastide e Costa Pinto, os quais defendem que as mudanças estruturais oriundas da transição da sociedade escravista para a sociedade de mão-de-obra livre revelaram o preconceito racial. Dessas transformações estruturais, eles enfocam o aspecto econômico, mostrando que a situação desvantajosa dos negros em processo de ascensão - no contexto da formação da sociedade de classes - levou a ações coletivas com vistas a questionar o preconceito que lhes servia de barreira social. 
A expressão política do protesto negro nos anos 30 em São Paulo fez-se notar pela ascensão num segmento desse grupo de cor e seu desejo de progredir na escala social, embora tivesse as suas chances limitadas pela discriminação, na interpretação de Queiroz. Passado o período de efervescência da mobilização política negra, os anos 50 deixam a capital paulista completamente esvaziada de protesto político de cunho racial; em contrapartida, as associações de lazer se fazem notar em números cada vez maiores. Esse contexto econômico reforça as explicações da autora, uma vez que:

fornecidos aos negros os meios de penetrar mais amplamente na pequena burguesia e, também, de se elevar até a média. Esta abertura diminuiu a frustração em relação à ascensão social, que se notava tão claramente nas associações políticas e nos artigos de seus jornais do periódico anterior; diminuída a frustração, as reivindicações amortecem (Idem, p. 246).

Para ela, a fonte de descontentamento entre os negros teria se enfraquecido. A causa disso foi o avançar do processo de industrialização, vivido pela cidade, que teria produzido num primeiro momento a segregação étnica, levando à formação das associações recreativas e depois o desenvolvimento das associações de tipo político. $\mathrm{Na}$ fase seguinte, a ampliação da industrialização teria favorecido a ascensão do negro esgotando sua fonte de protesto social. A relação entre o declínio do protesto e o crescimento econômico, com a conseqüente integração do negro como trabalhador estável e, até mesmo, como massa proletária, já tinha sido apresentada por Fernandes, em A integração do negro na sociedade de classes (1964). Assim, tanto o ascenso como a queda do movimento tem por causas as transformações econômicas na opinião desses autores.

Mas a década de 70 não foi apenas de reafirmação das explicações de Florestan Fernandes, Roger Bastide e Costa Pinto. Michael James Mitchell (1977) e Carlos Hasenbalg (1979) convergem com certas argumentações, porém colocam o problema de outro modo, introduzindo novas questões.

O cientista político Michael James Mitchell, cujo objeto de pesquisa foi o ativismo negro paulista. Em Racial consciousness and the political attitudes and behavior of blacks in São Paulo, título de sua tese de doutorado apresentado na Universidade de Indiana, em 1977, esse estudioso tem como problema de investigação a relação entre a consciência de raça e a ação coletiva. Assim, ele busca analisar os "efeitos da consciência racial" [effects of racial 
consciousness] nas práticas e atitudes políticas dos negros no Brasil, país que reivindica para si o ideário de democracia racial [racial democracy]. Dentre esses efeitos, o autor encontra deste opiniões individuais contra o preconceito racial até uma solidariedade entre os negros, motivada por uma identidade étnico-racial.

A pesquisa de Mitchell circunscreve-se à cidade de São Paulo ${ }^{11}$, onde surgiram as primeiras formas organizativas de caráter político, as quais também são tomadas como estudo de caso. Um pressuposto de Mitchell é que a consciência racial entre os negros não se limita ao período histórico da transição estrutural da escravidão para a sociedade de classes, isso porque as formas de dominação e subordinação raciais já estavam presentes antes e nelas já se poderia verificar a existência de formas contestatórias dos negros, como em revoltas e em movimentos políticos pela abolição. Essa visão rompe com as formas de explicação desenvolvidas anteriormente pelos sociólogos brasileiros.

Para Mitchell, as relações raciais permitem ver a tentativa de maximização do poder pelo grupo dominante, porém sob resistência do grupo subordinado. Tendo isso em vista, Mitchell entende que "as manifestações de consciência raça, tal como os objetivos de um grupo racial, podem maximizar o poder numa relação entre dominantes e dominados” (1977, p.256). Segundo ele, a vantagem dessa perspectiva é que ela se centra nas atitudes e nos comportamentos das relações entre grupos dominantes e grupos dominados, sem a utilização de categorias como castas ou classes. Esse tipo de abordagem lhe permitiria inferir que a consciência racial não aparece somente em momentos de transição social, mas sempre que existir relações de dominação e subordinação de uma raça por outra.

Nesse caso, a consciência torna-se mais nítida no momento em que vivenciam experiências de obstáculos raciais, considerados como empeço para ascensão social do negro. Desse modo, haveria algum grau de percepção de discriminação evidente no momento da disputa por carreiras profissionais no processo de mobilidade ascensional. Esse tipo de explicação aproxima Mitchell dos estudos feitos por Bastide, Fernandes, Costa Pinto e Queiroz; mesmo não sendo esse o ponto central do argumento dele. Isso porque Mitchell possui uma abordagem

\footnotetext{
${ }^{11}$ Não podemos precisar o grau de envolvimento político de Mitchell com as organizações negras de São Paulo, mas sabemos que ele desenvolveu palestras sobre temas relativos ao movimento negro. Em meados de 1976, por exemplo, Mitchell fez uma palestra intitulada "O movimento negro americano na década de 70" no ciclo de debates "O negro e as suas associações" do CECAN, Centro de Cultura e Arte Negra, um dos precursores do Movimento Negro Unificado na Cidade de São Paulo. Para mais informações (ver Silva, 1994).
} 
alternativa para pensar o comportamento e atitudes políticas raciais, o que lhe fez interpelar as relações raciais brasileiras e as ações coletivas dos negros a partir da dinâmica das relações de poder, entendida pelo binômio subordinação versus dominação. Assim, ele parte do pressuposto de que os grupos subordinados desenvolveriam uma consciência racial, baseada na solidariedade dos indivíduos, o que seria capaz de exercer resistência ao grupo racial dominante, além do que tal grau de consciência levaria o grupo subordinado a contestar o poder por meio de ação coletiva.

A solidariedade racial entre os negros também foi objeto de reflexão de Carlos Hasenbalg, em Discriminação e desigualdades raciais no Brasil, publicado em 1979. Contudo, ao contrário de Mitchell, o sociólogo argentino não fez uma pesquisa específica sobre o movimento negro, mas realizou um estudo sobre desigualdade racial no Brasil. No final de seu livro, Hasenbalg trata do tema "raça" e "política". Para tanto, o autor dedica um capítulo às reflexões em torno da baixa mobilização política dos negros na sociedade brasileira.

As causas sociológicas dessa baixa mobilização são múltiplas, mas o problema da ideologia estatal e da sociedade brasileira ganha proeminência, qual seja, o mito da democracia racial e a ideologia do embranquecimento. A construção da identidade coletiva entre os negros no Brasil estava comprometia, uma vez que estes assumiam os valores e as representações difundidas pelas elites dominantes e pelo Estado. Isso era confirmado pelo mecanismo social que permitia ascensão de alguns que podiam acessar o gradiente de cor, ou seja, especialmente os mulatos e os mestiços tinham a possibilidade da "saída de emergência" 12 , o que trazia conseqüências negativas para a construção identitária.

As poucas iniciativas do movimento não conseguiam reverter a situação do negro, o que fez com que o impacto de seu protesto ficasse restrito aos associados e ao seu pequeno raio de alcance, não velando a mudanças estruturais da condição de vida da maior parte da população negra. Em síntese: os movimentos não promoveram uma mobilidade social do grupo, nem conseguiram alterar a ideologia racial que sustenta a sociedade brasileira. Note-se bem que essa

\footnotetext{
${ }^{12}$ A expressão refere-se ao estudo de Carl Degler, historiador norte-americano que estudou as relações raciais brasileiras. Suas conclusões sugerem que os mestiços e os mulatos podem dispor de uma "válvula de segurança", garantida pelo sistema flexível de classificação racial brasileira. Para ele, tal dispositivo de emergência não poderia ser acionado por um indivíduo da mesma cor nos EUA. Para mais detalhes, ver DEGLER, Carl N. (1971) Nem branco nem preto: escravidão e relações raciais no Brasil e nos Estados Unidos. Rio de Janeiro: Labor do Brasil, 1976.
} 
será a principal tese defendida, mais tarde, por Michell Hanchard (2004) ao analisar o desempenho do movimento negro do pós Segunda Guerra Mundial.

Nos anos 80, sob o impacto da formação do movimento negro unificado, vê-se Seyferth (1982) e Rufino (1985) abordarem as distinções históricas, as diferenças ideológicas e práticas deste movimento, seja do ponto de vista da identidade ou da estratégia política. Nas palavras de Seyferth, em contraste com o período visto por Bastide e Fernandes:

(...) Os movimentos negros atuais - como o MNU, por exemplo - são fundamentalmente diferentes. A proposta de luta contra o preconceito e a discriminação permanece, mas os intelectuais e militantes negros dos anos 70 adotaram uma etnicidade afro-brasileira como estratégia de mobilização (1983, p. 11).

Já Joel Rufino (1985), no artigo intitulado "Movimento negro e a crise brasileira”, coloca nos devidos termos os dilemas enfrentados pela ação coletiva negra contemporânea no contexto de sua constituição, traduzidos pelo autor do seguinte modo: "deve-se considerar movimento negro exclusivamente o conjunto de entidades e ações dos últimos cinqüenta anos (...)" ; ou "deve-se considerar como tal todas as entidades, de qualquer natureza, e todas as ações de qualquer tempo (aí compreendidas mesmo aquelas que visam à auto-defesa física e cultural do negro), tornando-se a luta atual como simples prolongamento? ” (1985, p. 287).

Em poucas palavras, Rufino expressa o grande conflito do movimento negro em sua nova fase nos anos 70, uma vez que duas questões se intercruzam nos discursos do movimento: haveria uma distinção entre as organizações políticas e culturais? Em que termos as experiências políticas dos negros (Frente Negra e Teatro Experimental do Negro) deveriam ser consideradas para pensar o movimento negro contemporâneo? Isto é, a problemática de Rufino diz respeito à construção da história e da identidade para a militância, tarefa esta posta para seu corpo intelectual e ativista naquele período, no qual se insere o referido autor. $O$ fato é que neste momento em que Rufino escreve, o movimento negro é interpretado como resposta histórica ao 
"mito da democracia racial"13 - criada em 1930 pela política e pela intelectualidade brasileira e difundida por toda a sociedade sob o veículo do senso comum:

o movimento negro, no sentido estrito, foi, na sua infância (1931-1945), uma resposta canhestra à construção desse mito. Canhestra porque sua percepção das relações raciais, da sociedade global e das estratégias a serem adotadas, permaneceram no ventre do mito, como se fosse impossível olhá-lo de fora - e, historicamente, provavelmente o era" (1985, p. 289).

$\mathrm{Na}$ avaliação dele, haveria um contraste entre os discursos e as posturas do movimento negro no presente e no passado, Rufino afirma que a posição da Frente Negra e seus desdobramentos tinham estratégias nitidamente assimilacionistas, com certo grau de questionamento e de reivindicação, em contraste com o movimento negro unificado que tinha formas explícitas de ruptura com o modelo de nacionalidade brasileira, construída nos anos de 1930.

Diferentemente, Rufino e Seyferth, Clóvis Moura (1981) e Gonzalez (1982) tendem a reificar a história do movimento negro, mostrando relações quase causais entre a velha e a nova mobilização e levando a crer se constitui dessa continuidade linear e suposta harmonia entre as organizações estritamente políticas e as de cunho cultural.

Moura considera que, para explicar a emergência da mobilização negra de 70 , seria necessário um conhecimento da história das organizações negras e da "tradição" das entidades de diferentes perfis: religiosas, recreativas, culturais, políticas, assistenciais etc. Ao que parece, ele demonstrou que o movimento negro emergente no ano de 1978 estava sob bases bastante sólidas em termos de experiência associativa. Inspirado na tese do "espírito associativo do negro", de Arthur Ramos ${ }^{14}$, Moura mostra que havia uma espécie de tradição associativa entre os negros, ou seja, uma vivência longa que lhes davam uma certa experiência no tocante à formação de

\footnotetext{
${ }^{13}$ Hamilton Cardoso tinha a mesma opinião que Rufino. No ano de 1987, Hamilton Cardoso escreve um artigo para o livro Movimentos sociais na transição democrática, no qual o autor aponta para as novas imagens encontradas na sociedade brasileira vistas pelas "fissuras" que teriam sofrido a ideologia da democracia racial e "o ritual oficial brasileiro do racismo". As fissuras retratadas pelo autor não foram causadas pelas ações políticas e culturais, ambas faces de ações anti-racistas (Cardoso, 1987, p.95). Para Cardoso, são dois aspectos que marcam a mobilização negra dos anos 70 e 80: de um lado, a entrada de um ideário anti-racista introduzido pelos movimentos negros; de outro lado, "a nova identidade racial e cultural para os negros e, em certa medida, também para os brancos brasileiros" (idem, p.101). Essa contribuição das conquistas anti-racistas tem dado suporte de afirmação para as elites negras.

${ }^{14} \mathrm{O}$ artigo de Arthur Ramos, ao qual se refere Moura, chama-se "O espírito associativo do negro brasileiro", escrito em maio de 1938 para a Revista do Arquivo Municipal de São Paulo.
} 
organizações, construindo também uma espécie de "gosto" por associar-se. Embora os objetivos das associações fossem diversos, ele entendia que a marca do associativismo negro revela uma certa identidade étnica; esta, por sua vez, era resultante de um compartilhamento grupal que lhes permitiam algum sentimento de pertencimento coletivo, decorrente da experiência do preconceito de cor.

Gonzalez ratifica essa tese, mas também acena para influências contextuais da formação do movimento negro, como as mobilizações civis brasileiras(greves, movimentações estudantis e populares), as lutas de descolonização dos países africanos e as ações em defesa dos direitos civis nos EUA . Mesmo Clóvis Moura que enfatizou a dimensão de longa duração não esteve de todo errado. Certamente as experiências associativas dos movimentos negros servem de inspiração e suportes para a mobilização política, ou seja, os movimentos não surgem apenas de uma conjuntura política externa e conjuntural. Faltou apenas a este autor o desenvolvimento de argumentos e apresentação de evidências que permitissem mostrar como se deu essa passagem histórica.

Nos finais dos anos 80, a temática da identidade do movimento permanece em realce, a se notar pelas reflexões de Jônatas Silva (1988) e Nascimento (1989), os quais mostram a ascensão da dimensão cultural no interior no movimento, notadamente na valorização de certos símbolos de origem africana e dos EUA, na formação dos sujeitos políticos. Não menos importante, Nascimento demarca os conflitos no interior do movimento negro, revelando que nem todos os segmento defendiam a dimensão cultural como estratégia política, muitos, ao contrário, viam em certos aspectos culturais a possibilidade de alienação do negro. Silva concorda com Nascimento, mas salienta ainda que sem tal dimensão não se poderia explicar a emergência do movimento negro na Bahia nesse período. Explicação essa condizente com a argumentação que Butler (1998) desenvolveria mais tarde para explicar o perfil movimento negro baiano, em contrate com o paulista.

Em Nascimento, a problemática da identidade versus estratégia política foi refeita. Até que ponto a etnicidade como forma de identidade coletiva era prejudicial para as estratégias políticas do movimento negro? Essa pergunta seria norteadora daqueles que, ao analisarem empiricamente os movimentos, decepcionavam-se com as dificuldades que estes tinham em 
alcançar resultados diante da desigualdade e discriminação raciais. Esse problema percorreu toda a década de 80 e manteve-se até os anos 90, verificada em Maria Auxiliadora da Silva (1992) para o caso de Pernambuco; Joana Silva (1994) para as experiências de São Paulo; e Hanchard (2001) para a mobilização carioca e paulista. Desses autores, vale a pena olhar a pesquisa de Michael Hanchard com mais atenção, pois ele catalisou os temas centrais que percorreram essas três décadas.

Em seu doutorado, Hanchard (2001[1994]) estudou a mobilização dos negros cariocas e paulistas desde o pós-guerra até o centenário da abolição. Com base em suas fontes e no vasto e diverso trabalho de campo, Hanchard sustentou a existência de uma hegemonia racial, baseada no mito da democracia entre as raças, o que possibilitou a manutenção das desigualdades raciais no Brasil. Em contrapartida, houve uma experiência de mobilização negra que buscou reparar e corrigir parte dessas desigualdades através do movimento social, mas, na opinião do autor, as iniciativas foram relativamente pequenas, parcas e amiúdes, por conta de condições exteriores, tais como tipo de regime político e, sobretudo, as ideologias presentes no Estado e na sociedade brasileira, quais sejam: os ideários de democracia racial e de embranquecimento.

A despeito das ideologias comporem um campo de negociação entre os brasileiros, negros e brancos, elas atuavam no sentido de perpetuar as desigualdades raciais, uma vez que negavam a existência de práticas discriminatórias, assim, o Brasil era aclamado como democracia entre as raças, seja no plano institucional, ou no plano das interações do cotidiano. Essa dimensão ideológica se fez concretizar no campo da cultura, locus de negociação dos diferentes grupos raciais. Por haver uma apropriação de símbolos culturais afro-brasileiros pelo Estado, os negros tinham sérias dificuldades de questionar as desigualdades de cunho racial. Mesmo assim, na década de 70 e 80 , eles se organizaram para denunciar o racismo na sociedade, quando suas atitudes foram consideradas "afronta ao caráter nacional", salienta o autor.

Baseando-se nas formulações de Gramsci sobre a cultura e política, Hanchard, ao analisar as relações raciais no Brasil, sugere dois tipos de políticas adotadas pelo movimento negro: a primeira voltada para a identidade racial e étnica e a segunda baseada na reivindicação por igualdade. Ambas são consideradas políticas culturais, mas o que é fundamental no argumento é que essa forma de fazer política está em oposição a reivindicações mais prepositivas em termos 
de disputa por ascensão social dos negros e de distribuição de poder na sociedade ${ }^{15}$. O que houve na realidade brasileira, segundo o autor, foram tentativas sem sistematicidade e sem alcance nacional, incapazes de combater as desigualdades entre negros e brancos.

Essas tentativas chegaram a construir uma ideologia "contra-hegemônica", sobretudo a partir dos anos 70 quando os movimentos negros foram acusados de ameaçar a democracia racial estabelecida no Brasil. Os conteúdos ideológicos do movimento negro carioca e paulista combinavam influências das lutas dos negros norte-americanos e africanos. No Rio de Janeiro, por exemplo, há uma combinação da proposta americanista com a proposta africanista entre os grupos organizados daquele período. Mas, a despeito dessa caracterização, o autor termina sua tese enfatizando a tendência do movimento negro em rumar em direção ao culturalismo ${ }^{16}$, um caminho não recomendado por Hanchard.

O pensamento desse autor não é simples, porque analisa a articulação de três dimensões da vida em sociedade: a cultura, a política e a economia, sendo as duas primeiras o lócus de atuação do movimento social com possibilidade de alteração do campo econômico, no sentido da distribuição das oportunidades. Tendo isso em conta, as intervenções do movimento deveriam ser no plano político - especificamente no campo institucional -, através de propostas de políticas públicas efetivas, sem apelar para a esfera da cultura, pois nesse campo pairam as ideologias raciais compartilhadas em alguma medida por todos, por isso o plano cultural seria mais ambíguo e sujeito à dispersão, sobretudo porque o negro teria sido integrado no ideário da nação, através da música, da comida, dos esportes, das religiões e, mesmo assim, permaneciam nos estratos sociais mais baixos. O movimento com feições culturais poderia até ganhar no plano simbólico,

\footnotetext{
15 As principais críticas sofridas por Hanchard dizem respeito ao fato de que ele não leva em consideração a "política culturalista" como uma forma de fazer política de fato. Para os críticos dele, não existe uma maneira "absoluta" de se fazer política, de forma que o modelo de luta aberta, como a dos Direitos Civis, funcionou bem para os EUA, mas a realidade brasileira toma outro contorno. Esse foi o argumento de Luiza Bairros (1996), para quem a pergunta correta deveria ser: "que tipo de movimento negro foi gerado a partir da formação racial brasileira?" Essa questão possibilitaria uma melhor compreensão das experiências vividas por países como o Brasil e ajudaria a entender as ações políticas do movimento negro contemporâneo, segundo o argumento dela. O próprio Hanchard reconhece, no prefácio à edição brasileira de Orfeu e Poder (2001), publicado uma década depois da conclusão de sua pesquisa, que não previu as mudanças na sociedade brasileira sofridas no processo de redemocratização.

16 "Este capítulo mostrará como o culturalismo - a preocupação com os levantamentos genealógicos e com artefatos da cultura expressiva afro-brasileira - afastou o movimento negro das estratégias de mudança política contemporânea e aproximou-o de um protesto simbólico e de uma fetichização da cultura brasileira". (Hanchard 2001; p. 121).
} 
mas dificilmente alteraria os quadros de desigualdades do país. Tudo isso tornaria ainda mais complexa a relação entre cultura e política no processo de construção das identidades e estratégias do movimento social.

Essa questão não se esgota no pensamento de Hanchard. Como disse antes, trata-se de um problema que pauta a agenda de estudos das décadas recortadas, ainda que o trato dessa problemática receba abordagens e soluções diferenciadas. Mendonça (1996) e Cunha (1998), por exemplo, consideram eficazes as ações do movimento negro que envolvem as dimensões culturais, isso porque conseguem expandir a identidade negra para outros espaços e públicos, como as camadas negras de classe baixa, os jovens das cidades. A cultura, longe de ser um obstáculo para o movimento social, seria na verdade o lócus de resistência e de expansão do movimento, onde a sua eficácia política se mostraria com evidência, defendem as autoras.

\subsection{Algumas considerações}

Em conjunto, os estudos sobre os movimentos negros ainda possuem um tom descritivo muito característico das pesquisas sobre ação coletiva no Brasil, excetuando-se o trabalho de Hanchard. A precariedade das revisões bibliográficas feitas pelos pesquisadores prejudicou o desenvolvimento da pesquisa sobre esse assunto. Muitas questões "choviam no molhado", justamente pelo desconhecimento de trabalhos anteriores que davam realce aos mesmos aspectos. O frágil e deficiente diálogo entre as pesquisas foi sem dúvida alguma um impedimento forte para o avanço criativo nesta área nos últimos anos. O mesmo se pode dizer da ausência de interlocuções com outros trabalhos sobre movimentos sociais brasileiros. Por fim, saliente-se a quase ausência de da teoria dos movimentos sociais nessas pesquisas, afora as investidas de Hanchard. Sem nenhum respaldo teórico sobre ação coletiva, quase todos estudiosos limitavam-se a descrever aspectos mais salientes dos movimentos e, talvez por conta disso, viraram reféns dos discursos dos movimentos, talvez por conta da precariedade das ferramentas analíticas, capazes de interpelar e interpretar o objeto.

$\mathrm{Na}$ totalidade, estes estudos centraram-se em algumas indagações: como o movimento negro se formou? Para essa questão encontrar várias respostas, seja no veio das explicações 
estruturais (Queiroz 1979; Mitchell 1977; Hanchard, 2001), seja pelo viés das explicações que têm por base a história do próprio movimento social (Moura,1983), ou ainda pelas explicações do contexto social vivido na sociedade civil nacional e internacional (Rufino, 1984; Gonzalez, 1983; Cardoso1987; Nascimento, 1989).

A questão que ganhou centralidade nas últimas décadas foi o problema da identidade coletiva, contida no dilema fulcral: cultura versus política. A identidade esteve atrelada ao problema das estratégicas políticas, e estas relacionadas aos resultados alcançados pelo movimento, em geral considerados parcos. A identidade é um problema para alguns, porque ela estaria assumindo símbolos e representações étnicas, dispersando o movimento do problema central: o combate às desigualdades raciais (Hanchard, 2001) Mas, algumas das explicações que atrelam identidade à estratégia, e esta aos resultados, costumam trazer uma dimensão normativa para as reflexões.

Em termos metodológicos, os estudos não se prenderam somente às entrevistas com os integrantes dos movimentos. Muitos desses pesquisadores buscaram outras fontes como os documentos de eventos, das entidades e os jornais, além dos trabalhos etnográficos. Contudo, boa parte dos trabalhos centrou-se nos discursos das lideranças e dos fundadores, nesse sentido a pesquisa de Maués (1998) sobre a "questão racial no pensamento das elites negras" levou essa abordagem ao paroxismo. Assim, tais pesquisadores não conseguiram abarcar a questão da reprodução humana do movimento. Como ocorre o engajamento de mais integrantes nos movimentos? Como pensam os integrantes que não compõem as lideranças e fundação do movimento em questão? Essas perguntam não são respondidas, porque sequer foram formuladas.

A relação do movimento negro com seu exterior - como partido, Estado, mídia, outros movimentos sociais e ONGs - é pouco trabalhada nas pesquisas, a exceção se faz aos trabalhos de Andrews (1991), Jevanilda Santos (1992) e Hanchard (2001), que apontam uma relação do movimento com o Estado e os partidos políticos. Mas nos casos dos três autores tal relação contém uma negatividade, qual seja, as organizações estatais e partidárias estão longe de abrigar as demandas do movimento e o Estado, este é visto como seu principal oponente.

Essa abordagem comprometeu o aprofundamento das relações de network, do quadro de alianças e das formas estratégias que o movimento desenvolveu para ampliar negociar suas 
demandas com o Estado e os partidos. O foco das pesquisas preferiu evidenciar o movimento negro por si mesmo, ao invés de apresentar também as similitudes e contrastes em relação a outras formas organizativas. Uma hipótese plausível é que o interesse dos pesquisadores era afirmar a especificidade e a autonomia do movimento, desconsiderando a dimensão das redes de articulação e da reprodução em termos de capital humano, bens materiais e simbólicos. Com essa estratégia, os pesquisadores construíram um quadro em que o movimento atua contra os seus oponentes: Estado, governo, sociedade, partidos, sem que com isso pudessem construir aliados políticos em suas campanhas.

Com a consolidação do regime democrático no Brasil e as mudanças profundas sofridas no movimento negro ao longo da década de 90, o quadro dos estudos sobre esse movimento sofreu modificações. Como conseqüência, no alvorecer do século XXI, as pesquisas passam a preencher timidamente algumas lacunas diagnosticadas acima. Esse é o caso do trabalho de Santos (2005), que analisa o papel das conferências internacionais para o fortalecimento das organizações negras, bem como as pesquisas de Ivanir dos Santos (2004) e Walter Souza (2006), nas quais se pode entrever a relação entre movimento negro e Estado, em São Paulo e Bahia, respectivamente. Essa nova tendência de pesquisa talvez esteja sobre o impacto das transformações mais recentes do ativismo negro, sobretudo sob efeitos das investidas do movimento negro diante da democratização do país.

Essas transformações exigem tanto investigações empíricas, quanto arcabouço teórico para interpretá-las; sobre essa segunda exigência, repousa a investida do segundo capítulo. 


\section{DA SOCIOLOGIA DOS MOVIMENTOS SOCIAIS À TEORIA DA AÇÃO COLETIVA}

\subsection{Introdução}

Se no capítulo anterior me concentrei especificamente na produção sobre movimentos negros no Brasil; neste, detenho-me em algumas questões basilares para a pesquisa empírica exposta nos capítulos subseqüentes. O que são movimentos sociais? O que é identidade coletiva? Como pensar a relação entre movimento social, Estado e ambiente civil? E quais as contribuições dos estudos sobre movimento étnico-racial latino-americano para o caso da mobilização negra brasileira? Essas são algumas perguntas que nortearam minha investigação

As respostas para as primeiras perguntas levaram-me a investigar as principais correntes teóricas contemporâneas detidas no tema da ação coletiva, a saber: a Teoria dos Novos Movimentos Sociais, a Teoria de Mobilização de Recursos e a Teoria do Processo Político. Cada qual responde às minhas indagações de maneira distinta, isso porque a ação coletiva é vista sob prismas diferentes. Mas essas correntes teóricas estão longe de conter perspectivas irreconciliáveis. Aliás, os esforços atuais buscam construir uma teoria geral capaz de superar os problemas que desafiaram as últimas décadas, por exemplo, a relação entre estrutura, cultura e estratégia de ação.

Esse conjunto de questões faz-se presente nas pesquisas sobre América Latina, o que me

levou a recuperar algumas análises críticas da produção bibliográfica sobre a região. À luz dessas críticas, detenho-me em alguns estudos, em países vizinhos, que examinaram a mobilização de indígenas e de afro-latinos no período de abertura democrática, contexto esse em que se insere a atuação do movimento negro brasileiro para a qual se volta este trabalho.

\subsection{Os movimentos sociais na teoria sociológica contemporânea}

Os movimentos sociais que irromperam nos anos de 1960 e 1970 desafiaram as ciências sociais. Ao se depararem com essas formas de ação coletiva, os pesquisadores europeus e estadunidenses perceberam que o arsenal teórico à disposição, na época, não era suficiente para entender tal realidade. O surgimento dessas formas de ação coletiva criou a necessidade de 
ampliação de estudos empíricos e, por conseguinte, de redefinição das categorias analíticas, uma vez que os instrumentais das ciências sociais não eram suficientemente eficazes para explicar os movimentos da segunda metade do século XX.

Diante desses novos desafios, foi abandonada pelos cientistas sociais a explicação que relacionava a ação coletiva às crises estruturais de caráter econômico, a qual tomava os movimentos sociais como resultado de crise econômica e de desintegração social, especialmente entre os grupos mais excluídos. Abandonou-se também a vertente teórica que considerava os movimentos sociais como expressão de interesses compartilhados por causa de uma condição estrutural comum - a de classe. Ambas as correntes analisavam a ação coletiva apenas pelo viés estrutural, restringindo-se às dimensões econômicas. Enquanto as explicações funcionalistas viam as ações coletivas como reações não-racionais de grupos marginalizados, as análises marxistas, apesar de dotarem os movimentos sociais de racionalidade, não conseguiam estabelecer a ligação entre as condições econômicas e as ações coletivas, deixando em aberto a passagem da condição de classe para a consciência de classe, sem conseguir revelar os mecanismos capazes de estabelecer um elo entre a classe em si e a classe para si (Melucci, 1989).

Com efeito, as explicações funcionalistas e marxistas foram sucedidas por novos empreendimentos teóricos que tentaram responder aos problemas não resolvidos por aquelas formulações tradicionais. Em resposta, despontaram três correntes teóricas ${ }^{17}$ preocupadas em explicar os movimentos sociais contemporâneos, a saber, a teoria dos novos movimentos sociais (TNMS), a teoria de mobilização de recursos (TMR) e a teoria do processo político (TPP) (Edelman, 2001; Gohn, 2004).

A teoria dos novos movimentos sociais (TNMS) criticou diretamente as explicações marxistas, que estabeleciam um nexo causal entre consciência de classe e ação coletiva. A TNMS foi alocada no rol das teorias pós-marxistas, recebendo também a alcunha de "identityoriented Paradigm" (Cohen, 1985), fruto de um grande deslocamento teórico-metodológico feito por pesquisadores interessados em entender as formas de ação coletiva emergentes nos anos 60,

\footnotetext{
${ }^{17}$ Nem todos apresentam a divisão desse modo: Cohen e Arato (2000), por exemplo, vêem a TPP como um desdobramento da teoria de mobilização de recursos (TMR) e Munck (1997), apesar de reconhecer as contribuições da teoria do processo político (TPP), assegura que seus proponentes não saíram do referencial teórico proposto pela TMR.
} 
tais como os movimentos estudantis, ambientalistas, pacifistas, dentre outros, contrapostos aos das classes operárias, proeminentes no século XIX e na primeira metade do século XX (Pichardo, 1997).

A idéia de "novos movimentos sociais" toma como pressuposto a distinção entre as atitudes ideológicas das mobilizações coletivas "clássicas" e das contemporâneas. Assim, ao invés de demandas redistributivas, os "novos" movimentos demandariam qualidade e estilos de vida. Ademais, no entender dos analistas, esses movimentos questionariam as estruturas da democracia representativa, que limita a cidadania à representação nos governos e, em oposição a isto, advogariam em favor da cidadania participativa, assinalando o tema da autodefesa dos grupos e comunidades e democratização das esferas de poder. Tomados em conjunto, a sua novidade define-se pela busca de autonomia e identidade (Pichardo,1997, p.414).

Dentre os teóricos da TNMS, Alberto Melucci foi quem melhor elaborou o conceito de identidade coletiva. Esse pensador italiano estudou com Alain Touraine, um dos principais proponentes da TNMS. Touraine, ao deslocar-se da visão clássica marxista sobre ação coletiva, defendeu que a Europa Ocidental estava não mais no capitalismo industrial, mas no pósindustrial, no qual haveria uma outra forma de manifestação de conflitos, muito diferente das lutas de classes. Nessa nova fase do capitalismo, a ação coletiva apresenta-se em outras formas e em outros espaços, que não a fábrica (Touraine, 1997).

Contudo, Melucci não acompanhou completamente a visão de Touraine, antes buscou em Habermas a inspiração para falar da influência do Estado e do mercado na vida privada, recusando-se a fixar nas mudanças do capitalismo industrial a pré-condição para a formação coletiva dos novos movimentos sociais (Edelman, 2001). Segundo Habermas, tais movimentos crescem no "mundo da vida", em resposta à crescente racionalização do cotidiano. Sendo assim, eles lutariam diretamente contra o processo que coloca as relações, os serviços e o tempo submetidos à lógica do mercado e estariam contra o consumismo que define a esfera da vida privada e os estilos de vida. Para Habermas, "os novos conflitos não só se mobilizam por problemas de distribuição, mas sobretudo por uma gramática das formas de vida" (1981, p.33) .

Com base nesses referenciais sociológicos e na sua formação em psicologia social, Melucci elaborou uma definição própria de movimentos sociais. Esse conceito não poderia restringir a ação coletiva à dimensão do político, ou das instituições governamentais ou estatais, 
nem deixar de lado as demandas que incorrem sobre o cotidiano das pessoas. Isso porque os movimentos sociais operariam como redes informais, solidárias, "submersas na vida cotidiana" e, muitas vezes, de forma autônoma, com marcas culturais e identidades comuns. O desafio fundamental ao estudá-los seria perceber as transformações dos códigos da cultura, com alcance na vida social como um todo. Tendo isso em vista, diz ele:

Eu defino movimento social como uma forma de ação coletiva (a) baseada na solidariedade, (b) desenvolvendo um conflito (c) rompendo os limites do sistema em que ocorre a reação. (Melucci, 1989, p.57).

No entendimento de Melucci, o movimento social é definido como um tipo de ação construída coletivamente a partir dos laços de solidariedade estabelecidos entre os indivíduos ou grupos. O conflito mencionado por esse sociólogo italiano é aquele que o movimento trava contra os seus oponentes, como o Estado, o mercado e, sobretudo, o sistema cultural dominante. Porém, seu conceito não possibilita entrever a competição no interior dos movimentos e entre eles, não porque ignore o conflito entre os diversos atores que o compõem, mas em virtude de sua preferência por definir os movimentos pelos resultados advindos do estabelecimento das finalidades e do seu significado para os agentes. Mais do que os conflitos nos e entre os movimentos, Melucci (1989) busca identificar a solidariedade construída, que proporciona uma unidade para perseguir os fins propostos pelo coletivo.

Sem dúvida alguma, o grande mérito de Melucci foi inferir dos movimentos sociais o conceito de identidade coletiva, que busca cobrir uma falha antiga da sociologia: o velho dualismo entre a estrutura e a ação, entre as "condições objetivas" e as "motivações e orientações subjetivas" no agir em coletivo (Melucci, 1995, p.42). Interessado nessa questão, o autor compreende que somente a abordagem cultural conseguiria superar o dualismo sociológico. Assim, os estudos sobre o tema não poderiam prescindir de uma concepção de análise dos processos pelos quais "uma ação se torna coletiva".

O conceito de identidade coletiva é uma ferramenta analítica, e não um dado da realidade empírica, que ajuda o pesquisador a compreender como os atores constroem a si mesmos, em outras palavras, como se processa a "construção social do coletivo" (Melucci, 1995, p.44). Tal 
construção ocorre por constantes negociações e renegociações na medida em que as ações acontecem. Contudo, quando há quebra desse processo, "a ação se torna impossível” (idem, p.44). Portanto, além de ser condição de possibilidade para uma ação em conjunto, a identidade coletiva não é um elemento "natural" no interior dos movimentos sociais, tampouco se trata de uma representação construída sem disputas: ela depende de processos de negociação e constróise nas ações, no agir.

Assim, a identidade coletiva é construída num sistema de ação e envolve a dimensão cognitiva dos atores. Ela é, por definição, interativa e compartilhada por um conjunto de indivíduos ou grupos, sendo capaz de orientar as ações no campo de oportunidades e conflitos em que atuam; estabelecendo-se através de uma linguagem compartilhada por um grupo, um setor da sociedade, ou pela sociedade como um todo. Os elementos acionados na constituição da identidade coletiva são incorporados pelos indivíduos através "dos rituais, práticas e artefatos culturais" (Melucci, 1995, p.44), mas isso não nega uma dimensão racional dos indivíduos no processo de construção de suas identidades de grupo, visto que a identidade coletiva, segundo Melucci, segue algum tipo de cálculo entre os fins e significados, investimentos e retornos (ou ganhos).

Contudo, o conceito de identidade coletiva nunca pode ser reduzido ao cálculo de custobenefício, porque ela requer um investimento emocional: envolve paixões e sentimentos e mobiliza emoções, especialmente, em áreas da vida em que os movimentos sociais estão menos institucionalizados. Tudo isso possibilita o sentimento de pertencimento e unidade, por conseguinte, a identidade não é inteiramente negociada, porque a participação na ação coletiva está carregada de significados muitas vezes irretorquíveis para os agentes. Ainda assim, a aparente dualidade na construção desse conceito não poderia ser caracterizada pela existência de um lado racional e outro irracional da identidade coletiva; antes, é necessário compreender que não há "cognição sem sentimentos, nem significado sem emoção" (Melucci, 1995, p.45), o que desfaz uma possível aporia intelectual, mas ainda não resolve os problemas do ponto de vista do estudo empírico.

Com essa formulação teórica, Melucci reconstrói os contornos da teoria dos novos movimentos sociais, porém não sem considerar os seus limites, o que o fez assinalar a existência 
de certos pontos que deveriam ser aperfeiçoados nessa teoria. Segundo ele, a TNMS apresenta o motivo pelo qual os movimentos emergem, mas não explica como isso acontece, devido ao realce das "relações sistêmicas", que não leva tanto em conta a "lógica dos atores". Ela não esclarece satisfatoriamente como os movimentos mantêm sua estrutura, ou como se reproduzem. Como advertência, ele sugere que estudos empíricos no interior dessa teoria necessitam dar ênfase na ação concreta dos agentes.

Se essa é uma falha da TNMS, não se pode dizer a mesma coisa da teoria de mobilização de recursos que por sinal investiu no exame da forma pela qual os movimentos atuam. Mas essa forma de abordagem tem como pressuposto uma outra concepção de movimentos sociais. Influenciados pelas premissas fundamentais que embasam as análises do economista Olson, os proponentes da TMR investiram na lógica que orienta as ações e interesses dos atores, isto é, dos indivíduos engajados nas ações coletivas.

Mancur Olson foi um dos principais autores a refutar a tese da teoria clássica, segundo a qual haveria uma certa irracionalidade na ação dos indivíduos que se engajam nos movimentos sociais. Ele tornou-se uma referência para os proponentes da teoria de mobilização de recursos, garantindo análises focadas no agente puramente racional e enfatizando a "lógica rigorosamente individualista, utilitária" do ator que se insere no movimento (Cohen e Arato, 2000). Para Edelman (2001), a crítica sofrida por Olson foi de que ele teria levado ao extremo a caracterização específica do homo economicus, segundo a qual a ação coletiva era vista como uma soma de decisões estratégicas feitas pelos indivíduos, os quais poderiam ser induzidos a juntar-se ao grupo pelos incentivos ou sanções. Essa formulação sofreu grandes fissuras quando confrontada com os casos vividos nos anos de 1960, época de surgimento de vários movimentos sociais, em situações de estabilidade econômica e social nos EUA e na Europa Ocidental. Se fosse seguido o modelo da "escolha racional", não se conseguiria explicar a razão pela qual os ativistas decidiram agir no contexto de prosperidade econômica, explica Edelman.

Apesar das fissuras sofridas pela vertente da escolha rational choice olsoniana, muitas bases que fundamentavam sua teoria sobre os movimentos sociais serviram de alicerce para a construção da teoria de mobilização de recursos. A principal delas foi a racionalidade creditada aos atores e grupos mobilizados em movimentos sociais. Seguindo a perspectiva da racionalidade dos movimentos, McCarthy e Zald (1977), proponentes da TMR, vêem os 
movimentos sociais como grupos de interesse ${ }^{18}$, não se distinguindo substantivamente de outras formas organizacionais como partidos, associações ou empresas. A abordagem deles prioriza os âmbitos burocráticos e institucionais dos movimentos. Por conta disso, a variável mais importante para esses autores, bem como para os demais proponentes dessa corrente teórica, são os recursos, envolvendo, especialmente, a comunicação interna (no interior do movimento e entre as demais organizações) e externa (mídia) e os demais tipos de recursos, como o humano e o financeiro.

Com premissas alicerçadas em abordagens econômicas, McCarthy e Zald enfatizam a dimensão organizacional dos movimentos ${ }^{19}$, considerando que para se mobilizarem, eles precisam de infra-estrutura capaz de dar suporte ao seu estabelecimento. Uma das conseqüências dessa análise é que os movimentos são analisados como se estivessem num jogo competitivo, no qual o recurso é disputado entre eles, assim como as empresas disputam produtos e clientes no mercado econômico. Todavia, não é só por meio da competição que os movimentos sociais e suas organizações interagem, havendo, também, como os próprios autores notam, a interação por meio da cooperação entre diferentes organizações.

Como se vê, a abordagem da TMR enfoca a dimensão organizacional, a interação entre as organizações no interior dos movimentos sociais, bem como a profissionalização dos atores envolvidos na ação coletiva. A partir dessa abordagem, McCarthy e Zald elaboraram categorias analíticas para compreender a mobilização do movimento social, entendendo que este representa um conjunto de opiniões e crenças numa dada população, sendo que o movimento busca alterar alguns elementos da estrutura social e almeja ganhos materiais, de caráter redistributivo (McCarthy e Zald, 1977, p.1217).

A abordagem da TMR recebeu também muitas críticas: Jean Cohen (1985) demarcou de forma muito contundente os limite desta teoria. Segundo a autora, as organizações dos movimentos sociais não são apenas "mobilizadoras de recursos com intuito de servir aos objetivos da mobilização em larga escala e com apostas pelo poder do estado" (p.670), como

\footnotetext{
${ }^{18}$ No que se refere aos pontos problemáticos presentes nas formulações desses autores e estendidos para a corrente teórica a que pertencem, podemos citar a quase inexistência de uma abordagem voltada para as ideologias e motivações ideológicas dos movimentos (Cohen , 1985; Arato e Cohen, 2000).

${ }^{19}$ Gohn (2004) lembra-nos que McCarthy e Zald tomaram como objeto empírico os movimentos de direitos civis e o movimento de mulheres. Essas experiências foram bastante significativas para suas reflexões sobre o modo pelo qual os movimentos construíam estratégias para lidar com a mídia, a população em geral, bem como para angariar recursos financeiros (p.53).
} 
queriam os proponentes da TMR. Para além disso, tais organizações buscavam construir espaços e associações estruturadas democraticamente, com garantia da pluralidade dos atores políticos com vistas a intervenções na sociedade civil. Ela ressalta que muitos atores interpretam suas ações como afirmações de renovação da cultura democrática, introduzindo uma dimensão normativa na vida política. Alguns anos mais tarde, Edelman (2001) sintetiza as críticas dirigidas à teoria de mobilização de recursos: preocupada com o processo de mobilização e com a arregimentação de recursos, a teoria acaba por enfatizar demais os ganhos e o sucesso do movimento, desprezando as transformações de caráter cultural. Assim, a ênfase da teoria recairia sobre os ganhos materiais, e não nos ganhos simbólicos, constata o autor.

Dessas críticas, resultou um saldo positivo para as análises das mobilizações coletivas: um estudo deve balancear as duas dimensões em que atuam os movimentos sociais: a dimensão cultural, que contempla o plano da identidade e valores coletivos; e a dimensão pragmática, que contempla as ações, os ativistas, as práticas sociais, as formas e os espaços de atuação, bem como as fontes de recursos do movimento. A ênfase na primeira pode incorrer no erro de que falava Melucci; um peso desmedido na segunda pode levar aos equívocos dos proponentes da TMR, sobre os quais recaíram as críticas de Cohen e Edelman.

Os críticos que apontam falhas nas duas correntes teóricas consideram que a Teoria do Processo Político (TPP) teria resolvido alguns dos problemas enfrentados pela teoria sociológica. Alguns (Edelman,1997, Gohn, 2004; Toni, 2001) chegam a assinalar que a TPP preencheu algumas lacunas sociológicas nas pesquisas dessa área, porque teria realizado certas aproximações entre a teoria dos novos movimentos sociais e a teoria de mobilização de recursos.

McAdam (1985) apresenta a Teoria do Processo Político ${ }^{20}$ como uma alternativa ao modelo clássico e à teoria de mobilização de recursos; reconhecendo Charles Tilly como o seu principal proponente. A produção de Tilly é também conhecida por ter levado ao nível da investigação sociológica a relação entre movimentos sociais e o Estado, a qual teria sido longamente negligenciada pela literatura que tratava dos movimentos sociais (Della Porta,1996); da mesma opinião compartilha Munck (1997), para quem a TPP foi a teoria que melhor problematizou a relação entre a estrutura estatal e os movimentos sociais.

${ }^{20}$ O termo processo político tem sido adotado deste meados da década de 1970, quando Charlles Tilly e Rule introduziram-no na análise do processo político da Revolução Francesa (McAdam, 1982: 41-85). 
Tilly (2004) apresenta os movimentos sociais como uma forma de ação coletiva contenciosa $^{21}$, cuja forma de atuação, estratégias e repertórios variam e modificam-se ao longo do tempo. Em sua concepção, os movimentos sociais interagem com outras formas políticas e possuem íntima relação com os processos de democratização. Tilly é crítico das perspectivas que tomam os movimentos sociais como toda sorte de ação coletiva de tipo popular. O autor critica também as abordagens que não fazem a distinção analítica entre organizações sociais, suas redes de contato e os movimentos sociais propriamente ditos, com suas campanhas, demandas e bandeiras.

Ademais, sua teoria contrapõe-se à concepção que toma o movimento social como "ator único", pois tal formulação camuflaria os contínuos jogos de interesses, competições e alinhamentos políticos no interior e fora dos movimentos sociais, nem daria conta da "interação entre os ativistas", da construção de suas bandeiras, aliados, inimigos e públicos que constituem e promovem mudanças nos movimentos sociais (Tilly; 2004, p.7). Por essa mesma linha de raciocínio, Tilly questiona o livre uso do termo "movimentos sociais", o qual teria sido inflado com experiências de ações coletivas do passado e do presente, sem atentar para as mudanças históricas. Essa imprecisão construída pelo uso abusivo do termo prejudicaria a investigação da realidade concreta dos movimentos, isto é, o modo pelo qual eles realmente atuam: essa dificuldade recairia também sobre a possibilidade de situar os movimentos historicamente. Para além das experiências, o próprio conceito de movimento social recebeu várias acepções desde o seu surgimento.

Assim, Tilly considera que o movimento social assumiu historicamente a forma de um complexo de campanhas de reivindicações coletivas tendo como alvo as "autoridades", não se restringindo apenas ao Estado. Nesse complexo, inclui-se uma série de performances, tais como protestos, passeatas, congressos e exibições midiáticas, considerando também as representações públicas. Portanto, para Tilly, um movimento social é uma forma historicamente específica, que

\footnotetext{
${ }^{21}$ Não apenas os movimentos sociais seriam uma forma de ação contenciosa, uma revolução também estaria estabelecida nesse tipo de classificação. Doug McAdam, Sidney Tarrow e Charles Tilly, em Dynamics of Contention (2001), afirmam que uma política contenciosa possui duas variantes: a contida e a transgressiva (p.4). E ambas são importantes para entender uma luta política. Segundo eles, existem várias formas de ação contenciosa: movimentos sociais, revoluções, movimentos nacionalistas, democratização, ondas de greves e paralisações etc (Tarrow et al, 2001, p.4).
} 
se desenvolveu ao longo do século XVIII na Europa Ocidental e disseminou-se por outras partes do mundo.

Embora os movimentos sociais tenham sua história própria e particular, Tilly evita definir os movimentos sociais como um fenômeno suis generis e desconsidera a elaboração de explicações causais próprias para esse tipo de ação coletiva. Isto é, o surgimento e desenvolvimento dos movimentos sociais podem ser explicados da mesma forma que se explicaria qualquer tipo de política contenciosa. Para tanto, a ferramenta fundamental para essa teoria é o conceito de "oportunidades políticas", o qual foi melhor definido por Tarrow (2006).

Segundo Tarrow, as oportunidades políticas explicariam o motivo pelo qual os movimentos sociais apareceriam em momentos de crescimento econômico; essa formulação visa contrapor-se às explicações que relacionam os movimentos sociais às insatisfações econômicas e privações materiais. Com isso, o autor busca, nos processos políticos, as possibilidades explicativas para a emergência da ação coletiva de caráter contencioso, direcionando-se para o campo político.

Desse modo, as oportunidades políticas acontecem quando há abertura institucional, cisões entre as elites, realinhamentos políticos e alianças (com especial destaque para aliados influentes), ou fraqueza do Estado em sua capacidade de repressão. Nesses casos, o custo da inação seria muito alto, por isso essas situações tornam-se atraentes aos movimentos, configurando-se em oportunidades que acabam por produzir episódios para a ação política contestatória. Mas os movimentos não vivem apenas das oportunidades políticas externas, uma vez que os próprios ativistas podem criar e ampliá-las.

Esse arcabouço teórico da teoria do processo político, embora melhor formulado nos anos atuais, foi bem operacionalizado por Doug McAdam no início dos anos de 1980, quando escreveu seu livro acerca da mobilização dos negros estadunidenses. Sob a influência dos trabalhos de Tilly, McAdam adotou uma perspectiva de longa duração para analisar o caso do movimento negro dos EUA, enfatizando os aspectos políticos e processuais que teriam subsidiado a formação do protesto negro pelos direitos civis, que teve seu ápice nos anos 60 .

McAdam (1982) trabalha a emergência e o desenvolvimento da mobilização dos negros norte-americanos entre os anos de 1830 a 1970. Para tanto, o autor debate e critica a Teoria de 
Mobilização Recursos e o que chama de teoria clássica ${ }^{22}$. Seu trabalho é particularmente interessante, porque confronta os modelos teóricos às investigações empíricas, tomando como objeto o movimento negro, tema da presente dissertação.

Para McAdam, tanto a teoria de mobilização de recursos como a clássica explicam a origem dos movimentos sociais pela resposta dada aos estímulos da sociedade. Os movimentos sociais emergiriam de uma resposta a incentivos vindos de um momento imediatamente anterior ao seu aparecimento; em contrapartida, o modelo do processo político compreende que eles surgem em um longo período de tempo em resposta a um amplo processo político, econômico e social, que pode levar a uma "certa estrutura potencial para a ação coletiva" (p.60). A despeito dessas críticas, McAdam reconhece o avanço empreendido pela teoria de mobilização de recursos, a qual teria sustentado a racionalidade da ação coletiva, opondo-se assim às formulações da teoria clássica, cuja ênfase recairia sobre os aspectos psicológicos e não racionais da ação.

A rejeição de McAdam à teoria clássica e à teoria de mobilização de recursos deve-se ao fato de que nem as medidas de tensão e pressão social, nem a sustentação externa recebida pelos movimentos eram capazes de dar respostas significativas para explicar a emergência e desenvolvimento da mobilização negra estadunidense, no período recortado pelo autor.

Já a teoria do processo político apresenta-se como uma alternativa ao modelo clássico e à teoria de mobilização de recursos. Segundo ele, são duas as idéias fundamentais que precisam ser retidas desta teoria: ao contrário do paradigma clássico, os movimentos sociais são tomados como fenômenos políticos e não psicológicos. Assim, os fatores que determinam a institucionalização do processo político possuem a mesma utilidade analítica no estudo do surgimento do movimento. Em segundo lugar, o movimento social é visto como um contínuo

\footnotetext{
${ }^{22} \mathrm{O}$ conjunto de formulações, segundo esse autor, que partem de análises e descrições do sistema político norteamericano. A perspectiva pluralista da teoria clássica defenderia que nesse sistema existe uma larga distribuição de poder entre os grupos em competição, neste caso o poder não poderia estar concentrado nas mãos de um pequeno grupo na sociedade. O principal defensor dessa tese é Dahl, em Pluralist Democray In The United States (1967), que tinha como problemática a eficiência da democracia norte-americana. A implicação mais negativa dessas formulações diz respeito à incompreensão de grupos outsiders, ou seja, aqueles que tendem a lutar por outras vias para expor suas demandas. Sendo este o caso do movimento negro, uma vez que a população afro-americana teve ao longo da história grande dificuldade de inserção na política institucional, como afirma McAdam. Dentre os limites da teoria clássica, foram os pressupostos de democracia pluralista que impediram os analistas de enxergar os movimentos sociais como uma forma de ação racional e eficiente para os grupos excluídos, segundo a avaliação do autor.
} 
processo de reprodução geracional até o seu declínio, ao invés de uma série discreta de desenvolvimento de estágios. De acordo com essa idéia, qualquer modelo completo de surgimento de movimento social pode oferecer ao pesquisador uma estrutura interpretativa para analisar uma fase inteira de desenvolvimento, ao invés de um período em particular.

No estudo de McAdam, as organizações mobilizadas tornam-se unidades de análise. Assim, o peso da mobilização relaciona-se diretamente ao número de organizações, sua inserção na comunidade, seus recursos, sua capacidade de organização e comunicação entre si. Desse ponto de vista, a análise do autor ainda está sob grande influência da TMR. O elemento flagrante da distinção entre TMR e TPP, nas análises de McAdam, é a abordagem de longa duração, em que os processos históricos são imprescindíveis para sua explicação, bem como as dimensões políticas imbricadas neles.

Por conta disso, o autor toma a teoria do processo político, porque esta consegue dar conta dos fatores sociológicos que se configuram no momento de constituição do movimento negro. Tais fatores podem ser encontrados historicamente pela abertura da estrutura de oportunidades políticas construídas nos anos de 1930 a 1950, sobretudo pela forte intervenção federal empreendida por meio da suprema corte, a qual respondeu negativamente às medidas locais de discriminação e segregação racial. No segundo momento, ocorre a expansão das oportunidades políticas que passa a contribuir para o crescimento da sensação da eficácia política, revelado pela ampliação e pelo aumento do nível organizacional do movimento e pela multiplicação dos atos e protestos públicos empreendidos pelo mesmo. Por último, o autor recorta o final da década de 60 para mostrar como ocorreu o declínio do movimento negro no auge de seu estabelecimento em termos de recursos de financiamento, refutando, assim, o elemento econômico como fator preponderante para explicar as ações do movimento social.

No que se refere aos aspectos metodológicos, McAdam prefere uma investigação de tipo quantitativa, muito semelhante àquelas realizadas pelos proponentes da TMR. Seu banco de dados é construído a partir da catalogação dos eventos, passeatas e protestos realizados pelo movimento, considerando os aspectos numéricos como pessoas e recorrência (simultânea) de ações em diferentes áreas do país. Preocupa-se, assim, com a extensão do movimento em termos de área de alcance, distribuição e concentração em certas regiões. A quantidade de protesto realizada num dado período, a capacidade de mobilização de recursos, processos judiciais e atos 
públicos são medidas utilizadas para comparar os ciclos de efervescência e decadência dos movimentos, em suas diferentes fases históricas. A fonte principal a que recorre é os dados obtidos através dos jornais, sobretudo o New York Times, dos quais ele retira informações específicas sobre as movimentações. Com certa prudência, McAdam argumenta que tal tipo de procedimento pode ser reprovável quando se pensa em análise de curta duração, mas quando se trata de investigações e ciclos longos de movimentações políticas, o uso dos jornais pode auxiliar na coleta de informações, uma vez que o risco da super valorização ou subvalorização dos eventos podem ser controlados por uma análise detida de um tempo mais longo. Sendo o caso esses dados eficientes especialmente para pesquisar processos macro-sociais.

A partir das evidências levantadas do conjunto de seus dados, McAdam estabelece uma relação causal entre a mobilização política dos negros e as mudanças ocorridas no sistema institucional norte-americano, ou seja, entre as estruturas de mobilização (como as igrejas, associações e organizações sociais) e as mudanças abrangentes ocorridas na política institucional (como as eleições partidárias, aberturas no sistema jurídico federal, posicionamento internacional dos EUA frente aos acontecimentos políticos da época etc). Contudo, o autor não nos apresenta os mecanismos pelos quais tal relação se processa, isto é, os níveis intermediários que permitem articulação entre os agentes e a estrutura. Ficamos sem saber ao certo como ocorre a passagem entre as mudanças micro e macro- sociais, até porque o autor não está preocupado em analisar as ações dos atores coletivos em suas particularidades, preferindo, antes, investigar mudanças no âmbito da dinâmica das organizações e protestos.

Uma outra crítica plausível ao trabalho de McAdam diz respeito à ausência de uma análise cultural do movimento negro. Apesar de considerar a dimensão da solidariedade como fundamental para as explicações da emergência e sustentação do movimento, McAdam só consegue apreender uma dimensão da solidariedade que é a da doação de recursos materiais (econômicos) e humanos; em sua análise, fica de fora qualquer tipo de explicação que envolva a identidade coletiva do movimento social. Por ele, sabe-se apenas que a solidariedade e a cognição são elementos fundamentais para a mobilização coletiva, mas não se sabe como elas se articulam no processo político. Essa falha pode ser explicada, em parte, porque sua abordagem prescinde dos discursos que os agentes formulam sobre si mesmos, ou seja, as interpretações dos 
indivíduos sobre os processos em que estão envolvidos. Assim, McAdam não nos responde como as dimensões culturais e políticas amarram-se na mobilização social.

Essa ausência no trabalho de McAdam pode ser estendida a todos os proponentes da Teoria de Mobilização de Recursos e da Teoria do Processo Político sobretudo até o final da década de 80, como constatam as avaliações críticas (Muller, 1992). Com efeito, o problema da racionalidade do ator coletivo foi por muito tempo um fardo pesado para a TMR e TPP. Mas, segundo Carol Mueller, o peso da herança olsoniana passou a ser contrabalançado quando os cientistas sociais herdeiros dessa tradição observaram com mais afinco as relações sociais em que estavam enraizados os atores. O cálculo de custo-benefício passou a ser visto como uma avaliação e interpretação dos atores em contextos sociais, socialmente construídos por lealdades, obrigações sociais e identidades, servindo de suporte ao engajamento social e à mobilização coletiva. Com isso, entra em cena uma perspectiva analítica da micromobilização, enfatizando a interação face-to-face dos atores sociais, particularmente as relações sociais da vida diária.

Dessa maneira, a TMR e a TPP passam a dialogar intensamente com a problemática fundamental da TNMS. Se a cultura era um problema central para a teoria dos novos movimentos sociais, as demais corrente teóricas que não deram muita atenção à dimensão cultural da ação coletiva, agora passam a considerá-la por entender que a ausência de tal dimensão prejudica a análise dos movimentos sociais. Ao fazer um balanço sobre as gerações dos estudos sobre movimentos sociais, Mueller (1992) constata o interesse por relacionar os atores e contextos - nos quais os significados são desenvolvidos e transformados. O conteúdo cultural dos movimentos sociais passou a despertar o interesse dos cientistas da TMR e TPP na medida em que esses respondiam aos críticos. Isso ofereceu possibilidade para abordagens que contemplassem as dimensões estruturais e culturais da ação coletiva. Assim, as interpretações e as avaliações dos atores são levadas em consideração na análise dos movimentos sociais e as falhas que são apresentadas vêem sendo enfrentadas, como pode ser notado nas reflexões feitas por McAdam e Friedam (1992) sobre a relação entre identidade coletiva e engajamento social.

Nesse novo esforço, McAdam, em parceria com Friedam, busca inspiração em Weber para definir identidade coletiva como um "pronunciamento público de status" (p.156), que implicaria num conjunto de atitudes, compromissos e regras comportamentais os quais 
permitiriam a filiação do individuo ao movimento. Uma vez assumida certa identidade coletiva, o sujeito chamaria para si certas expectativas sociais, tanto dos demais filiados ao movimento como da sociedade em geral. Assumir essa identidade é resultado de um processo intersubjetivo: não só diz acerca das expectativas externas ao indivíduo, mas das suas próprias. Nessa investida, McAdam pensa ter dado uma resposta satisfatória ao problema da conexão entre identidade coletiva, networks e escolha, sem reduzir esta última ao esquema da escolha racional, mas também sem dar o caráter psicossocial elaborado por Melucci.

No final da década de 90, McAdam reedita seu livro sobre a mobilização negra norteamericana e reapresenta de forma mais evidente os conceitos fundamentais, que, segundo ele, articulam perspectivas racionalistas, culturalistas e estruturalistas. Na segunda edição de Political Process and the Development of Black Insurgency (1999), o estudioso estadunidense oferece aos pesquisadores uma síntese das questões que lhe ocupou durante quase duas décadas, a considerar o ano de seu ingresso no doutorado que resultou na pesquisa sobre os Direitos Civis.

Nessa nova versão, McAdam reafirma o fator oportunidades políticas como explicação para emergência dos movimentos sociais e acentua, de forma mais veemente, a importância da ação contenciosa dos grupos contestadores. Mantém o autor o peso das organizações que dão suporte ao movimento, as chamadas estruturas de mobilização, que por sua vez são definidas como: "veículos coletivos, formais ou informais, através dos quais as pessoas mobilizam-se e engajam-se em uma dada ação coletiva" (p.11). O papel da informalidade ou das formas subterrâneas de solidariedade ganha mais expressão nas análises de McAdam, se comparado à primeira edição de seu livro.

Em que pese a maior precisão dos conceitos e o rigor na delimitação dos fatores causais para emergência da ação coletiva, MaCdam investe mais do que antes no campo intermediário, entre a estrutura de oportunidades políticas e a estrutura de mobilização coletiva. Trata-se de um investimento que tenta tornar analiticamente apreensível o nível meso das disputas de poder. As áreas intermediárias entre as dimensões micro e macro sociais são compreendidas pela estrutura de significados ou pelo esquema cultural em que se inserem os grupos em disputa. Nessa estrutura, as sensações de otimismo ou pessimismo podem ser elaboradas pelos indivíduos, bem como as identidades coletivas. Mais do que avaliação ou estratégia, nesse campo encontra-se o 
ambiente propício para a cognição, que é o modo pelo qual os indivíduos apreendem a realidade social. É bem verdade que, apesar da cognição oferecer margem para os sentimentos e sensações, o autor pretende reforçar os aspectos racionais (ou conscientes) da perspectiva cognitiva, por conta disso enfatiza a percepção dos atores num dado contexto político, e não suas emoções. Com esses reparos, McAdam apresenta novamente a moldura da teoria do processo político, compreendia no modelo da ação contenciosa, o qual se sustenta numa compreensão particular do modo pelo qual a cultura pode ser operada nas análises empíricas sobre movimentos sociais. Em que pesem os avanços empreendidos por McAdam e os demais proponentes dessa teoria, os analistas continuaram reclamando lacunas nas pesquisas.

Apesar de reconhecer um crescente interesse na abordagem cultural das mobilizações coletivas - o que teria superado as perspectivas restritas aos cálculos estratégicos salientes nos herdeiros da teoria olsoniana - , James Jasper (2003) considera que esses avanços teóricos ainda resistiram à incorporação das emoções nas análises das manifestações sociais ${ }^{23}$. "As emoções desapareceram dos modelos de análise de protestos" (p.152), indigna-se o autor ao observar as produções dos anos de 1980 e 1990. Isso porque as emoções para aqueles analistas estariam compreendidas no campo da irracionalidade, essa, porém, não é a visão de Jasper. Para ele, as emoções se constituem na cultura e são enlaçados de valores morais, por isso deveriam ser tomados como causas sociológicas para a explicação da ação coletiva. Em seu entender, elas também são razões para o ativismo político.

Seja no veio da avaliação - que injeta um grau mais elevado de racionalidade instrumental -, seja na corrente da cognição - a qual abre margem para o quadro cultural compartilhado pelos contestadores e seus oponentes -, Jasper argumenta que em ambas perspectivas, as emoções são tidas como causas secundárias, pois foram interpretadas como canais de acesso às motivações irracionais dos indivíduos, o que não interessaria à análise da ação coletiva contemporânea. É como se a emoção fosse temida por todos, já que elas carregariam doses fortes de irracionalidade. Sem desconsiderar esses perigos, o autor aposta na emoção como uma das explicações que não

\footnotetext{
${ }^{23}$ Segundo Jasper, as emoções fizeram-se presentes nas abordagens sociológicas da primeira metade do século XX, quando as teorias do comportamento de massa insistiam na dimensão irracional das mobilizações coletivas. Nessa perspectiva, as emoções eram sentimentos de medo, de raiva e frustração, as quais foram apreendidos nas categorias de anomia e alienação. Ao rejeitar o modelo da anomia, alienação e irracionalidade para estudar os movimentos sociais, os analistas contemporâneos excluíram de suas análises motivações orientadas por sentimento.
} 
pode desaparecer das análises, dado que sua ausência compromete a teoria sociológica sobre ação coletiva.

Assim, ele rejeita as formulações presas somente às escolhas racionais dos agentes e às interpretações restritas às estruturas cognitivas, uma vez que os sentimentos, para ele, permeiam as idéias, as identidades e os interesses (p.154); Jasper voltando-se, então, para o tema das emoções, tão caro aos escritos de Melucci e tão desprezado pela TMR e TPP. Para ele, o projeto dos teóricos dessas duas últimas correntes teóricas descartou as motivações subjetivas dos indivíduos nos protestos políticos, reduzindo-os quase sempre aos interesses materiais, econômicos e políticos. Jasper se vale de um argumento bastante convincente, pois, segundo ele, "as emoções estão em toda vida social, inclusive nos movimentos sociais" (p.153). Sendo assim, não haveria porque circunscrever as razões de mobilização coletiva apenas a "objetivos, estratégias e oportunidades políticas”.

Se isso é verdade, como analisar emoções em estudos de movimentos sociais? Uma resposta apresentada pelo o autor é a investigação do sistema de valores locais, incluindo os direitos e obrigações dos indivíduos numa dada sociedade. Isso implica na observação do contexto social do país ou região, no qual os agentes deitam suas raízes morais. O sistema simbólico compartilhado pelos indivíduos constitui-se por regras e condutas, as quais são difundidas por um conjunto de narrativas comuns compartilhadas pelos indivíduos. São exatamente essas narrativas que mobilizam sentimentos e emoções, por isso são tão caras aos movimentos sociais e aos ativistas, em particular. Assim, as emoções estão na formação da ação coletiva, mas também resultam delas:

Emoções são um dos produtos da ação coletiva, especialmente dos rituais internos do movimento. Ritos coletivos reportam os participantes aos seus compromissos morais, incita fortes emoções e reforça um sentimento de solidariedade de grupo, de um 'nós' coletivo. (p.161)

Nessa perspectiva, Jasper considera que o movimento é constituído por rituais - que são personificações simbólicas de crenças e sentimentos de grupos - mobilizados em tempos e espaços propícios. Tomando como exemplo o movimento dos Direitos Civis, o autor refere-se à 
relevância dos cantos, músicas, danças e estórias narradas nos protestos negros norteamericanos.

Especificamente as narrativas de protestos também foram objeto de análise de Poletta (2006), que as considera fundamentais para a formação de grupo e ações coletivas. Segundo a autora, tais estórias são revestidas de autoridade para defender causas sociais, servindo de base para argumentação e justificação num debate ou numa luta social. Ademais, essas mesmas narrativas podem aproximar grupos que possuem demandas distintas, mesmo porque essas estórias são polissêmicas, marcadas por variações e nuanças. Isso as torna mais maleáveis, porque diferentes versões sobre a mesma história podem ser contadas de acordo com os espaços em que se encontram os defensores de uma causa em particular.

Em seus estudos, percebeu que as narrativas sobre os movimentos sociais costumam ser evocadas para formular defesas de mulheres nos tribunais ou de negros no congresso e no senado americanos, por exemplo. Assim, a autora verifica que o impacto dos protestos extrapola os espaços em que ocorrem e que estes podem ser incorporados no discurso, ou numa narrativa retórica, da luta política institucional, como o fazem democratas nos parlamentos ao recorrerem à figura de Martin Luther King ao argumentar em favor justiça e igualdade de cunho racial. Contudo, a apropriação das estórias não ocorre de maneira aleatória, lembra a autora, os agentes legítimos para o seu uso costumam ser indivíduos ou grupos que possuem algum tipo de ligação ou são referenciados às narrativas selecionadas, que são postas em cena para contornar certos impasses políticos e judiciais.

Mais do que argumentar que as narrativas investem autoridade nos grupos subordinados que se apropriam de certos discursos do passado em defesa de interesses do presente - Poletta considera que essas concorrem com àquelas produzidas pelo Estado, que também constrói suas próprias narrativas, nas quais sustentam sua legitimidade. Nesse sentido, tanto as autoridades e instituições como os grupos utilizam-se de narrativas para se auto-representar e tornar seus interesses legítimos. Ocorrer que tanto um como o outro precisa compartilhar um mesmo esquema cultural, particularmente os grupos com menos poder necessitam mobilizar referências do repertório da comunidade política em que contestam as regras e os valores sociais dominantes. 
Nessa perspectiva, as reflexões de Ann Swidler (1986) revestem-se de atualidade. Para ela, a cultura ofereceria o repertório de possibilidades para as quais se voltariam os agentes sociais no processo de construção das estratégias operadas na ação, não desconsiderando o fato de que os contextos históricos são variáveis fundamentais para a relação entre cultura e estrutura, pois estas não são realidades estáticas. Longe de pensar a cultura como valores últimos ou um todo coerente dotado de sentido que orientam a ação humana, Swidler apresenta um modelo alternativo para analisá-la, que compreende os símbolos, as estórias, os pontos de vista, rituais diários os quais são selecionados por indivíduos ou grupos em suas estratégias de ação.

Desse modo, a cultura também teria o papel de circunscrever o leque de possibilidades dos agentes, uma vez que aquela além de ser o lócus dos repertórios de ação, estabelece os limites das escolhas estratégicas. Neste caso, a questão fundamental é saber como os atores utilizam-se da cultura no agir em coletivo. Essas questões expostas como Swidler fizeram eco nas investigações dos anos 90, quando abordagens culturais ganham cada vez mais proeminência nas pesquisas sobre ação coletiva.

Pelo exposto, o problema central das teorias em exame é apresentar uma formulação teórica satisfatória e capaz de explicar as ações coletivas em suas múltiplas dimensões, sem deixar escapar os elementos fundamentais que as constituem. A ênfase na estratégia, conduzida pelo veio da racionalidade, deixou de fora - por muito tempo - a dimensão cultural e subjetiva constituinte da ação coletiva, sem a qual o analista não pode explicar como os indivíduos engajam-se num protesto ou numa organização em situações em que a inação é a atitude mais racional a ser tomada. Não fossem os esforços de Melucci, a teoria sociológica teria perdido em muito a dimensão cultural na qual se fundamenta a identidade coletiva. Os esforços da TMR e TPP não foram menores, viram-se quase que obrigados a dar uma resposta contundente em que fosse possível operacionalizar a cultura, seja do ponto de vista do engajamento social, ou de sua ligação com a estrutura social de onde partem os caminhos escolhidos pelos movimentos.

Tendo em vista essas contribuições formais para o estudo da ação coletiva, vejamos como essa discussão foi recebida e encaminhada nas pesquisas sobre o caso da América Latina nas últimas três décadas. 


\subsection{O Caso Latino-Americano}

Assim como aconteceu nos Estados Unidos e na Europa ocidental, os estudos sobre movimentos sociais ganharam novo coro e novas roupagens na América Latina a partir dos anos 70. Impulsionados e impressionados com a mobilização social em seus países, os estudiosos latino-americanos trataram de interpretar as formas de ação coletiva organizadas por grupos e camadas sociais até então desacreditados pelas Ciências Sociais ${ }^{24}$. Contudo, a realidade aqui não foi idêntica àquela vivida pelos EUA e pelos países europeus. Na América Latina, tais estudos floresceram num ambiente em que o autoritarismo ganhou forma de regime.

Das teorias apresentadas na primeira parte deste texto, a dos novos movimentos sociais exerceu maior influência sobre os pensadores latino-americanos ${ }^{25}$. Essa influência fica evidente não apenas nas formas de abordagens e na ênfase nas identidades dos atores, como também na incorporação da nomenclatura. Toni (2001) considera que a teoria de mobilização de recursos foi rejeitada pelos intelectuais da América Latina, porque a TMR pressupunha o modelo norteamericano de democracia pluralista, realidade distante daquela em que os regimes de ditaduras serviam de palco para atuação dos movimentos sociais. A interpretação foi de que aquela teoria era muito específica, sendo incapaz de dar conta do contexto latino-americano. $\mathrm{O}$ fato de os norte-americanos ignorarem a possibilidade de o Estado ser um oponente dos movimentos sociais divergia frontalmente com as interpretações e explicações formuladas para pensar os movimentos latino-americanos, considera Toni. Já Gohn (2004) argumenta que "as teorias norteamericanas, fundadas nas ações coletivas dos comportamentos sociais, tradicionalmente consideradas funcionalistas, conservadoras e utilitaristas, não eram nem lembradas” (p.216), especialmente porque pairava um certo sentimento antiamericano estendido para o campo acadêmico.

\footnotetext{
${ }^{24}$ Segundo Paoli e Sader (1986), a tradição sociológica sobre os movimentos sociais não via potencial político nas classes populares, tidas como alienadas nos processos políticos decisórios. Por conta disso, na época da efervescência política de 70, os estudiosos se surpreenderam com a mobilização popular, afirmam esses autores.

${ }^{25}$ Gohn (2004) chama a atenção para o fato de que os estudos latino-americanos dos anos 70 , feitos basicamente no Brasil, Chile, México e Argentina ainda estavam influenciados pelo marxismo, somente na década seguinte houve uma absorção mais generalizada da TNMS: "a influência teórica européia inicial se fez predominantemente por meio do paradigma marxista (...) A abordagem marxista foi sendo substituída pela dos novos movimentos sociais ao longo dos anos 80" (Gohn, 2004, p.216).
} 
$\mathrm{Na}$ mesma direção, Edelman (2001) salienta que esses pesquisadores apresentavam objeções ao uso da categoria "oportunidade política" em suas análises. Isso porque parecia descabida a hipótese de que houvesse oportunidades políticas em pleno contexto de ditadura e essa recusa da TPP deixou espaço aberto para a teoria dos novos movimentos sociais na América Latina, especialmente, ele argumenta, para a influência de Alain Touraine, que teria sido um elo forte entre TNMS e as pesquisas latino-americanas. Edelman considera que a vinda da TNMS da Europa Ocidental para o território latino-americano permitiu o aprofundamento da investigação das desigualdades econômicas. Assim, os estudos priorizaram os movimentos com demandas de caráter redistributivo, notadamente aqueles caracterizados como populares (Idem, p.294).

Contraditoriamente, Allain Touraine (1988) critica os estudiosos latino-americanos pelo uso inadequado da categoria movimentos sociais na América Latina. Segundo ele, tais pesquisadores estariam sob a influência norte-americana, para quem o movimento social se definiria por ser um grupo de interesse. Nas palavras dele:

muitos sociólogos latino-americanos, seguindo o costume que domina nos Estados Unidos, chamam de movimentos sociais protestos que permanecem à margem do sistema político, mas que não vão além dos objetivos específicos e limitados que são os do grupo de interesses. (p.279).

Para Touraine, os movimentos da América Latina evidenciavam somente a crise do sistema políticos desta região, mas não apresentavam "atores coletivos desejosos e capazes de pôr em causa a organização social" (p.280). Assim, esses movimentos tenderiam a negociar mais facilmente com o Estado do que construir uma mobilização forte e ampla entre a população. Tais movimentos não teriam papel de mudança da ordem social, suas ações, no máximo, seriam capazes de ajudar na reconstituição do sistema político. Por conta disso, o autor chamou as formas de ações coletivas de levantes, sublevações, contidas numa onda de "movimentismo". Aquilo que os teóricos cunhavam de movimentos sociais não passava de grupos de afirmação de identidade, que muitas vezes se manifestava em forma de protesto social: 
Portanto, é mais perigoso do que útil falar de movimentos sociais, pois os fenômenos que acabam de ser evocados não tem a mesma natureza das lutas gerais entre adversários sociais, aos que se reconhece quase sempre o nome de movimento sociais, Falemos, aqui, de movimentos de base ou até mesmo de sublevações, mas não de movimentos sociais. (p.281).

Essa crítica de Touraine não fez eco na América Latina, que manteve o uso do termo para analisar as mobilizações coletivas dessa região. Ruth Cardoso (1987) assinala que a produção latino-americana sobre os movimentos sociais voltou-se para o estudo do protesto das camadas pobres, num momento em que se intensificava a "participação dos setores populares, através de novas formas de associativismo". Essa realidade instigou os intelectuais a observarem esses setores, negligenciando outras formas de movimentos tais como o feminista, ecológico, antiracista etc. A autora considera que, nesses estudos, os movimentos sociais repousavam numa vasta imprecisão conceitual (Cardoso, p. 28). A falta de aprofundamento teórico combinava-se com os problemas metodológicos presentes naquelas pesquisas: trabalhos muito descritivos e pouco analíticos, resultantes de investigações esvaziadas em entrevistas longas, transcritas sem o distanciamento necessário à pesquisa acadêmica. Pautados na pesquisa participante e no engajamento apaixonado, os cientistas sociais não teriam conseguido uma análise satisfatória do objeto; ao contrário, verificava-se um enfoque nos discursos dos atores, levando "o investigador a tomar o discurso dos movimentos como a descrição de sua ação" (p. 29), em detrimento do estudo das formas organizacionais e das estratégias políticas dos mesmos; sem considerar, aliás, o grande otimismo desses intelectuais, que acabavam por formular interpretações "utópicas", e até românticas, dos movimentos.

No caso brasileiro, os estudiosos viam os movimentos sociais como contraposição "à cultura autoritária vigente", tornando-os "sujeitos por excelência do processo de criação e de generalização da cultura democrática, através de novas formas de práticas políticas e novos formatos de sociabilidade, fundados em bases igualitárias" (Dossiê Unicamp, ano 1998/1999, p.20).

De modo geral, na América Latina, a crise do Estado foi interpretada como desencadeadora dos movimentos sociais, sendo estes o motor da democratização. O Estado era visto pelos pesquisadores como o inimigo dos movimentos sociais e as análises detinham-se na 
sociedade, e não na esfera pública estatal. Tomando como referencial a TNMS, os estudos aqui preferiram trabalhar com as idéias de significado e de símbolos, ao invés de estudar as estratégias na "arena política", argumenta Cardoso (1987).

Ruth Cardoso (1992) dividiu a trajetória dos movimentos sociais em duas fases. Uma delas foi chamada de "emergência heróica dos movimentos", iniciada nos anos 70, que se estende até os anos 80. O segundo momento seria o da institucionalização, entendida como a abertura de certas "agências do Estado", o que possibilitou novas formas de participação antes tolhida pela ditadura. A primeira fase teria sido descrita pelos cientistas como a fase da "espontaneidade" e da "autonomia", em relação à esfera estatal e aos partidos; enquanto que a segunda fase foi entendida como o momento de "cooptação" e refluxos dos movimentos sociais. A razão para essa separação tem suas causas, defende a autora, e uma delas tem a ver com o fato dos pesquisadores voltarem-se mais para os discursos dos militantes, e menos para suas práticas, ou seja, a produção acadêmica teria privilegiado certas dimensões dos movimentos, negligenciando ${ }^{26}$ as relações que eles estabeleciam com outras organizações civis e estatais - era o momento da "pesquisa social engajada e pouco crítica", diz Cardoso. Não se pode negar, todavia, que se tratavam de contextos políticos distintos: no início da década de 80, a relação do Estado com os movimentos sociais era outra, despontava o processo de democratização e com ela a possibilidade de institucionalização das demandas dos movimentos; caso oposto ocorrera na década anterior em que os movimentos não conseguiam interlocução com o Estado. Nesse caso, pondera Cardoso, não se trata apenas de uma mudança no interior dos movimentos sociais, mas sobretudo da transformação do contexto político em que eles estavam inseridos.

Com efeito, as transformações narradas por Cardoso não escaparam aos olhos dos pesquisadores da década de 90, anos de estabelecimento das democracias nos países latinoamericanos. Assim, o maior desafio das pesquisas foi analisar a atuação dos movimentos sociais no contexto político da abertura democrática, quando houve uma nova configuração do Estado e

\footnotetext{
${ }^{26}$ Cardoso (1994) também pondera o fato de se tratar de um contexto ideológico particular. Naquele período de repressão e bipartidarismo, era complicado apresentar as relações entre os movimentos e os partidos políticos. Na passagem a seguir, a autora chama a atenção para isso: "naquele momento não se via a presença de agentes políticos dentro dos movimentos porque isso não podia ser escrito, porque havia realmente uma situação de pressão política" (p.85). Um comentário muito próximo ao de Cardoso foi feito por Gohn, com ênfase especial sobre a relação entre movimentos sociais e partidos políticos: "talvez a questão dos partidos seja a menos trabalhada nas pesquisas sobre os movimentos sociais - principalmente nos populares -, porque vários intelectuais que escreveram sobre eles eram também lideranças político-partidárias - não tinham interesse na época de deixar clara tal relação" (2004, p.235).
} 
do regime de governo. Aliás, não só a redemocratização, mas também o neoliberalismo como política econômica configurou o quadro sobre o qual os agentes coletivos esboçaram suas ações e desenharam seus projetos de intervenção. Maticce (2005), debruçado sobre as novas produções desse período, sustenta que a relação entre movimento e Estado passou a ser objeto dos novos estudos. Argumenta ainda que os processos democráticos engendrados em diferentes países e a forma de implementação das reformas liberais não têm sido homogêneas na América Latina. Os pesquisadores, contudo, ainda têm tomado esses processos macro-sociais sem atentar para esse fato. Assim, as pesquisas tomam o neoliberalismo e a democratização como "fenômenos indiferenciados e uniformes"(p.238), pois não apresentam os meandros das relações entre os movimentos e os formuladores das políticas econômicas e sociais.

Em termos de abordagens, os estudos latino-americanos enfatizaram a parte cultural dos movimentos sociais, apontando para a intersecção entre política e cultura e sugerindo que essas duas dimensões entrelaçam-se no fazer político dos movimentos, agora atuantes em regimes democráticos. O empreendimento mais notável que segue essa direção foi realizado por Sônia Alvarez, Evelina Dagnino e Artur Escobar [1998; (2000)]. Nesse trabalho, encontram-se esforços que tentam resolver certos problemas herdados do pensamento marxista ocidental nas análises dos movimentos sociais latino-americanos. Assim, os autores investem no campo teórico apresentado por Alberto Melucci. Ademais, a investida dos autores busca inspiração nos estudos culturais e no pós-estruturalismo, ressaltando a importância da política cultural como forma de analisar a ação coletiva e enfatizando a linguagem e os significados das ações dos agentes, com base em seus discursos.

Segundo Alvarez et al., na América Latina contemporânea, "todos os movimentos sociais põem em prática uma política cultural" (2000, p.22), considerando que tanto as estratégias como as identidades dos movimentos estão em alguma medida "vinculadas à cultura" (p.23). Desfazendo-se, assim, a distinção antiga entre velhos e novos movimentos sociais, entre os movimentos de interesses materiais e os identitários. Na política cultural, os objetivos dos movimentos sociais são investigados a partir do laço constitutivo entre política e cultura, em que esta é "uma concepção do mundo, como um conjunto de significados que integram práticas sociais" (p.17), sem deixar de fora as relações de poder operadas em tais práticas. 
Segundo essa concepção, a política cultural empreendida pelos movimentos sociais latinoamericanos teria como objeto estabelecer um projeto democrático, disputando com concepções de democracia ligadas ao neoliberalismo que apregoa o Estado mínimo. Assim, tais movimentos alargariam o conceito de política, disputaria com as concepções dominantes de democracia e “desafiariam práticas políticas dominantes” (p.23).

Nessa direção, vai o artigo de Grueso, Rosero e Escobar. Os autores apresentam o modo pelo qual a identidade negra afro-colombiana vincula "cultura, território e conservação da biodiversidade" (p.325) na construção de projeto de desenvolvimento alternativo ao proposto pelo Estado. A ênfase aqui recai sobre a estratégia de politização da cultura como forma de resistir a projetos de desenvolvimento econômico com impactos negativos sobre o modo de vida local. Assim, o surgimento da identidade negra do Pacífico colombiano teria se construído num processo de luta contra as mudanças estruturais de caráter econômico que visam solapar os modos de vida dessas comunidades. Neste caso, os autores apresentam uma hipótese explicativa plausível para a constituição dos movimentos, mas ainda assim a carência de evidências deixa a formulação enfraquecida, sobretudo porque o argumento mobiliza apenas explicações de caráter contextual, o que torna a explicação causal pautada no binômio ação/reação. As comunidades aparecem como reservatórios de identidade prontos a reagirem às transformações sociais e atuarem no espaço público através de mobilização coletiva.

Em consonância com essa perspectiva, Olívia Cunha que, ao analisar o grupo brasileiro Afro-reggae, assinala a estratégia cultural utilizada pelos ativistas para alcançar a população negra, mostrando, ao mesmo tempo, que a própria identidade coletiva do grupo se constrói em suas atividades político-culturais. A hipótese central da autora é que é possível unir essas duas vertentes, a política e a cultura, tornando-as instrumentos eficazes para a luta anti-racista. $\mathrm{Na}$ verdade, a eficácia da intervenção é associada à dimensão da cultura, pois é a partir dela que os discursos do movimento negro podem ter maior alcance, atingindo os negros de classes baixas e outros setores da população brasileira. Como a autora centra-se apenas nos discursos dos ativistas, suas hipóteses e conclusões se enfraquecem. Ademais, a autora restringe a concepção de cultura à sua dimensão instrumental, eximindo-se de abordá-la nos termos amplos propostos por 
Melucci. Nesse caso, o processo de construção da identidade, referido por Olívia Cunha em seu estudo, é um dado apriorístico, e não uma demonstração sociológica ${ }^{27}$.

Em ambos os estudos, a centralidade das pesquisas recai sobre as estratégias de mobilização comunitária, sobre os discursos dos ativistas e, notadamente, sobre o prisma da dimensão simbólica do movimento social, repetindo equívocos já formulados por Cardoso.

Em outra perspectiva, Van Cott (2001) aborda os movimentos étnicos na América Latina, incorporando o prisma da Teoria do Processo Político. Cott toma como estudos de caso a Colômbia e a Bolívia, cujas experiências de reforma constitucional revelam as negociações entre as elites políticas e os movimentos indígenas e negros. Tendo como contexto político o processo de democratização desses países e as reformas de cunho neoliberais, Coot identifica que o processo de elaboração da Constituição foi tomado como oportunidade política para os movimentos emplacarem suas demandas. Neste caso, a autora estuda as reivindicações dos movimentos, bem como as estratégias políticas adotadas pelos mesmos.

Embora a dimensão estratégica da mobilização coletiva ganhe destaque na análise, Cott recorre ao poder explicativo da cultura para compreensão das tramas políticas que envolveram os movimentos étnicos, o Estado e a opinião pública ${ }^{28}$. Segundo ela, o quadro interpretativo no qual se inserem as reivindicações destes movimentos relaciona-se diretamente com o modo pelo qual foi construída a "identidade nacional" [national identity] dos países, porque é a partir e contra ela que os grupos organizados se insurgem.

De maneira geral, as identidades nacionais desenvolvidas na América Latina foram construídas por meio da dissolução legal de identidades étnicas. Isso acarretou o surgimento de um movimento de caráter assimilacionista no campo da cultura, da língua e das crenças tidas como nacionais. Na prática, as populações indígenas e negras foram submetidas ao regime legal

\footnotetext{
${ }^{27}$ No caso do movimento negro no Brasil, o estudo que melhor elabora a relação entre identidade coletiva e sistema cultural é o de Michel Agier (1992). Para ele, o movimento constituiu sua forma identitária a partir da lógica cultural do país, operacionalizando a linguagem e categorias do sistema cultural, mas alterando os seus significados na arena pública. Por isso, o movimento negro seria "um produto das relações racializadas do país" e sua luta consistiria na redefinição simbólica da cultura hegemônica.

${ }^{28}$ Influenciada por Coot, Hooker (2005), em seu estudo sobre os ganhos obtidos pelos movimentos indígenas e negros na América Latina, mostra que o peso da negociação da identidade coletiva - frente o Estado e opinião pública - é decisivo para o sucesso do movimento social. Segundo ela, os indígenas teriam sido mais bem-sucedidos em suas conquistas, porque o argumento étnico para tais povos era mais cognoscível socialmente,ao contrário dos negros que não eram reconhecidos por sua etnicidade.
} 
de tutela e à "ideologia racista" [racist ideology] que sustentava a formulação do nacional pela superioridade étnica das elites, defende a autora.

Ocorre que esse modelo de estado-nacional passou por um processo profundo de perda de legitimidade, expresso pela crise de participação, descrenças na representatividade dos partidos e por intensas crises econômicas. Em reposta, e na tentativa de recuperar a legitimidade social, as elites teriam se esforçado para desenvolver reformas profundas em suas constituições.

Guardadas as devidas proporções do quadro geral investigado por Cott, pode-se dizer que um retrato análogo comporta a realidade do Brasil nas últimas décadas. O processo de democratização brasileiro, que coincidiu com a época dos preparos para o centenário da abolição, foi francamente utilizado pelo movimento negro brasileiro, que aproveitou a abertura institucional e o contexto simbólico em favor de suas reivindicações. Isso pode ser visto de forma mais objetiva nos protestos ocorridos em várias partes do país durante esse período, que mostrou o potencial mobilizador do movimento e sua experiência organizacional. Esse contexto de luta pela abertura e consolidação das instituições democráticas foi um dos principais motores para a institucionalização deste movimento, num grau sem precedentes em toda a história política do país.

\subsection{Algumas Considerações}

Tanto a abordagem cultural, incluindo a dimensão das emoções, quanto a perspectiva estrutural, especialmente no que toca às organizações e sua relações com Estado, governo e demais autoridades e instituições serão mobilizadas na análise dos dados empíricos coletados em meu trabalho de campo. Tendo isso em vista, optei por trabalhar com a abordagem da teoria do processo político, incorporando as críticas que seus proponentes sofreram ao longo dos anos. Nas áreas de minha pesquisa empírica que a TPP não possui ferramentas para acessar, recorrerei às reflexões de autores que estudam os movimentos sociais fora desse campo teórico.

Assim, perspectivas culturalistas como a de Jasper e Poletta, os quais chamam a atenção para as emoções nos protestos e as narrativas mobilizadas pelos grupos subordinados, parecem pertinentes quando relacionadas às contribuições de Swidler acerca da cultura. Esta autora, por sua vez, apresenta um conceito que me pareceu adequado para operar a idéia de repertório 
defendida por Tilly. Esse arranjo conceitual, oferece parte das categorias formais necessárias a minha pesquisa, a qual interpela o movimento social através das motivações individuais, das formas organizacionais e da performance dos protestos.

Nessa direção, recorrerei aos componentes formais elaborados pelos autores analisados neste capítulo. Cada um, ao seu modo, oferece contribuições analíticas pertinentes ao problema de minha pesquisa; por conta disso, pretendo lançar mão daquelas ferramentas mais adequadas face à realidade e às condições objetivas em que atuam o movimento negro no Brasil contemporâneo. 


\section{UM CASO DE INSTITUCIONALIZAÇÃO DO MOVIMENTO NEGRO: A FORMAÇÃO DA EDUCAFRO}

\subsection{Introdução}

A pesquisa em torno das organizações e lideranças foi tradicionalmente o meio pelo qual se acessava o movimento negro. Essa estratégia fica mais difícil à medida que o perfil do ativismo afro-brasileiro se torna mais complexo e socialmente heterogêneo. Hoje, pode-se afirmar que esse movimento possui estruturas de mobilização (McAdam, 1982; 1999) em praticamente todos os estados do país ${ }^{29}$. Também é possível dizer que algumas de suas organizações têm maior influência e visibilidade do que outras na cena nacional. Deste modo, tomaremos uma entidade reconhecidamente importante no espaço público e com extensa capilaridade social para entender as características da ação coletiva negra do Brasil contemporâneo.

Essa estratégia pode acarretar um sério obstáculo epistemológico: restringir a totalidade do movimento à particularidade da organização estudada. Para sair dessa encruzilhada, optei por investigar esta forma de estrutura de mobilização, que é expressiva para o movimento negro atual, e no capítulo subseqüente analisarei as marchas de protestos, em que é possível observar a pluralidade desse movimento.

A organização escolhida foi a Educafro - Educação e Cidadania para afro-descendentes e carentes -, porque se trata de uma das maiores entidades do movimento negro brasileiro, apresentando-se na cena pública com alto poder de mobilização, capaz de promover protestos de rua e sustentar as principais bandeiras da militância negra, como a reivindicação por ações

\footnotetext{
${ }^{29}$ Os levantamentos de iniciativas e organizações negras da década de 90 realizados por Rosana Heringer (2001) e a coleta de trajetórias das lideranças do movimento negro feito por Alberti e Pereira (2007) oferecem um panorama rico da ação do movimento negro nos diferentes estados do país.
} 
afirmativas no ensino superior ${ }^{30}$. Todas essas qualidades estão diretamente relacionadas ao que denomino institucionalização do movimento negro.

A Educafro surge no ano de 1997, em São Paulo, sob a liderança de Frei David Raimundo Santos. Contudo, os processos sociais que levaram à sua formação exigem o estudo do seu grupo fundador e de suas tentativas de luta contra a discriminação e as desigualdades raciais. Para isso, separo três momentos distintos no texto. O primeiro momento manifesta-se através da emergência das subjetividades negras; o segundo momento é caracterizado pela formação de ações coletivas voltadas para a denúncia da discriminação e desigualdades raciais; e, por fim, o terceiro constitui-se pela elaboração de projetos e iniciativas que visam aumentar as oportunidades sociais dos negros, levando à institucionalização das iniciativas civis. A unidade de análise é o indivíduo no caso inicial; na seqüência, temos como objeto os grupos e as alianças com outros movimentos e organizações; já no último momento apresentado a entidade ganha significação sociológica na medida em que se complexifica, passando a negociar com as autoridades, com intento de construir políticas públicas voltadas para a população negra e pobre do Brasil. Quando se aplica esse modelo para o caso do movimento negro em geral, logo se percebe que esses momentos não são lineares - podem ser simultâneos -, mas precisam ser apreendidos em sua historicidade para que o leitor consiga localizar a formação do movimento social e identificar suas transformações.

Nos finais dos anos 70, a temática racial ganha mais visibilidade pública e reverbera sobre certas estruturas de poder. Mas não se trata apenas de um processo de mudança em escala estrutural, existem transformações que acontecem no plano dos indivíduos (Melucci, 1994),

\footnotetext{
${ }^{30}$ Existe uma ampla literatura que discute as ações afirmativas no Brasil. Uma das definições mais aceitas pelos defensores dessa política é a do Jurista Joaquim Barbosa , segundo a qual: " [... atualmente, as ações afirmativas podem ser definidas como um conjunto de políticas públicas e privadas de caráter compulsório, facultativo ou voluntário, concebidas com vistas ao combate à discriminação racial, de gênero, de origem nacional, bem como para corrigir os efeitos presentes da discriminação praticada no passado, tendo por objetivo a concretização do ideal de efetiva igualdade acesso a bens fundamentais como a educação e o emprego. Diferentemente das políticas antidiscriminatórias tradicionais baseadas em leis de conteúdo meramente proibitivo, que se singularizam por oferecerem às respectivas vítimas tão somente instrumentos de caráter reparatório e de intervenção ex post facto, as ações afirmativas têm natureza multifacetária, e visam evitar que a discriminação se verifique nas formas usualmente conhecidas - isto é, formalmente, por meio de normas de aplicação geral ou específica, ou através de mecanismos informais, difusos, estruturais, enraizados nas práticas culturais e no imaginário coletivo (2003, p. 28).
} 
quando as subjetividades se constróem em diferentes espaços ${ }^{31}$, ampliando assim a possibilidade de arranjos coletivos diversificados.

Nos anos da redemocratização, já ocorre uma cena de articulação social, em que ativistas tentam convencer e arregimentar pessoas para a causa racial. Ainda não se tem a complexidade das organizações atuais, mas é o momento de construção de bandeiras, demandas, símbolos e projetos. Esse momento é marcado pela interação face-a-face. Aqui a dimensão microssocial é mais proeminente, porque os indivíduos estão em processo de negociação e convencimento de outras pessoas para a formação de uma ação coletiva (Mueller, 1994). Isso se processa através de reuniões mais ou menos informais, encontros e seminários. Nesse momento, formam-se os ativistas, os fundadores; confeccionam-se as primeiras redes de solidariedade informal e os coletivos políticos. Neles, o grupo de fundadores arrisca a construção de aliados próximos, interessados na causa, formando, assim, uma rede submersa entrelaçada por relações e alianças interpessoais. Embora essas redes informais tenham proeminência, já se pode verificar evidências de formas em processo de institucionalização ${ }^{32}$.

No decorrer da década de 1990, ocorre a complexificação das organizações, as quais se desenvolvem aos poucos a partir dos recursos que conseguem, das pessoas mobilizadas e através das oportunidades que captam e ampliam no processo da luta social. Nesse momento, o raio de atuação da entidade estende-se, porque os aliados e a base alargam-se. Aqui, abrem-se as possibilidades de negociação com o governo, intensificado na gestão de Fernando Henrique Cardoso. Mas ainda há uma tensão no interior do movimento: nem todos apóiam alianças com

\footnotetext{
${ }^{31}$ Os bailes blacks foram os lugares para os quais a literatura aponta com intuito de mostrar os espaços de sociabilidade negra antes da formação do MNU. Nesses bailes, muitos ativistas, sobretudo os cariocas e paulistas, manipularam alguns dos principais símbolos da identidade negra do Brasil contemporâneo. (Ver Gonzalez, 1983, Rufino, 1986, Hanchard, 2001).

${ }^{32}$ Durante a década de 80, o movimento negro transita em alguns espaços institucionais, como é o caso do Conselho da Condição Feminina, em que as mulheres negras conquistam uma representação, ainda que minoritária. No ano de 1984, é construído o Conselho da Comunidade Negra, no qual passam a circular setores do movimento negro, inclusive líderes do MNU, segundo depoimento do ativista Billy, cedido a Mim, em setembro de 2007. No ano de 1988, é criado, na gestão do Presidente Sarney, o primeiro órgão voltado para assuntos da comunidade negra, a Fundação Palmares. Afora esses modelos estatais, durante os anos de redemocratização surgiram algumas das ONGs negras mais influentes da década de 90, como Maria Mulher (1987), Instituto do Negro Padre Batista (1987); Geledés, Instituto da Mulher Negra, (1988); Unegro, União dos Negros pela Igualdade (1988); CEAP, Centro de Articulações de Populações Marginalizadas (1989), dentre outras.
} 
governo. Ademais, FHC tem uma resposta ainda tímida para o movimento negro, de modo que a Educafro preferiu ficar na oposição ${ }^{33}$.

Na gestão de Luis Inácio Lula da Silva, ocorre uma abertura política maior tanto para os movimentos sociais como para as organizações civis, segundo Sallum Jr e Kugelmas "o modo Lula de Governar" foi resultado dos compromissos estabelecidos durante a campanha eleitoral, assim: “ele foi eleito comprometendo-se a governar 'negociando' sistematicamente tanto com os partidos políticos quanto com as organizações representativas dos vários segmentos da sociedade" (2004, p.257). Essa maior abertura possibilitou uma articulação mais intensa entre o movimento negro e o governo, a qual ainda precisa ser caracterizada. Nesse sentido, a organização estudada revela aspectos importantes dessa relação. A Educafro, com os demais setores do movimento negro, engaja-se e apóia as políticas públicas do governo, especialmente as de cunho educacional. Neste momento, o movimento e o governo assumem compromissos públicos e tornam-se aliados políticos. O primeiro avalia que deve aproveitar o segundo como aliado e não como opositor. Estreitam-se, pois, os laços entre ambos ${ }^{34}$.

\subsection{Novas subjetividades negras}

Os processos sociais que levaram à formação da Educafro - e a própria institucionalização do movimento negro - não podem ser entendidos fora das transformações ocorridas no Brasil contemporâneo, que reverberaram no plano dos indivíduos, das instituições e das organizações construídas a partir do movimento social. Nesta análise, a primeira instituição que deve ser objeto de cuidadosa atenção é a Igreja Católica e suas mudanças nos anos de 1960 e

\footnotetext{
${ }^{33}$ No que toca à política educacional, foi desenvolvido no final do segundo mandato de FHC (2001-2002) o programa Diversidade na Universidade, o qual financiava cursinhos pré-vestibulares para grupos excluídos. Na sua primeira versão ou projeto piloto, os cursinhos do Núcleo de Consciência Negra da USP, do Steve Biko e da Afrobrás receberem recursos financeiros para sustentarem suas iniciativas. Na época, a Educafro foi refratária a essa política de governo manifestando-se contrária a esse tipo de intervenção do estado, defendendo o não financiamento e a autonomia das organizações negras da sociedade civil. (Depoimentos de coordenadores da Educafro cedido a mim, em 2006 e 2007, em São Paulo).

${ }^{34} \mathrm{O}$ primeiro selo do compromisso social do Governo Lula com o movimento negro foi a formação da SEPPIR, a Secretaria Especial de Promoção da Igualdade Racial, e a nomeação de Matilde Ribeiro para o cargo de Ministra. Tratava-se de uma figura estratégica, porque era uma mulher negra que possuía algumas qualidades como inserção no movimento negro, pois tinha sido fundadora e coordenadora executiva da Soweto, uma organização negra paulista; era integrante do PT e tinha experiência de administração pública no ABC Paulista.
} 
$1970 .^{35}$ Isso porque a Educafro é fruto de um trabalho pastoral ligado à ordem religiosa dos franciscanos. As mudanças da Igreja a que me refiro são aquelas surgidas tanto no Concílio Vaticano II (1962 a 1965) como nas Conferências Gerais do Episcopado Latino-Americano (CELAM) de Medellín, na Colômbia (1968) e de Puebla, no México (1979). Nesta última, a Igreja Católica compromete-se com as causas dos pobres e identifica os indígenas e os negros como os grupos mais desfavorecidos na América Latina. Pelas condições de pobreza e sofrimento no mundo, indígenas e negros transfiguraram-se em Cristo, ganhando suas feições:

Situação de extrema pobreza generalizada na América Latina adquire, na vida real, feições concretíssimas, nas quais deveríamos reconhecer as feições sofredoras de Cristo, o senhor (...) Feições de indígenas e com freqüência também de afro-americanos, que vivem segregados em situações desumanas, que podem ser considerados como os mais pobres dentre os pobres. (Documento da Conferência Puebla apud Santos, 2006, p.47).

Nessa mesma época, no interior da Igreja Católica, surgiram religiosos interessados em desenvolver projetos e ações voltadas para a população negra. Mas isso não ocorreu de forma mecânica e imediata. Talvez a experiência de um dos seminaristas deste período possa ilustrar a mediação entre mudanças estruturais da igreja e a motivação individual dos religiosos, que combinados levaram à formação de um movimento eclesial negro. Ou seja, uma versão do movimento negro que mobiliza, pelo menos, duas categorias identitárias, a da religião e a da cor da pele. O católico e o negro.

A experiência de que dispomos é a de um seminarista nascido em Minas Gerais, filho de mãe costureira e pai vendedor, ambos baianos que rumaram ao sudeste à procura de melhores condições de vida. No seminário, em Petrópolis-RJ, o jovem ingressante foi vítima de discriminação, que teria alterado a forma de pensar sua identidade: "[..] sofri uma violência racial que me fez mudar radicalmente a minha postura; arrumei a mala para vir embora, abandonando o seminário"36.

\footnotetext{
${ }^{35}$ Eder Sader (1995), ao estudar os movimentos sociais populares em São Paulo, identifica o papel da Igreja Católica no processo de formação e mobilização popular. Ele argumenta: "As transformações ocorridas então na Igreja não podem ser subestimadas. De outro lado, a formação das comissões pastorais e as comunidades de base não devem ser vistas como simples sucedâneos de organização anteriores que incorporavam leigos e dirigiam suas ações para a vida profana. Agora tais organismos interferiam também na própria organização interna da Igreja, alterando o funcionamento das paróquias e o papel dos vigários. De outro lado, as críticas feitas a organização social não se limitavam a questões secundárias, mas denunciavam os próprios fundamentos do sistema.” (p.150)

${ }^{36}$ Entrevista de Frei David dos Santos concedida a Contins, 2005, p.153.
} 
A violência a que se refere David dos Santos aconteceu três meses depois de ter ingressado no seminário, justamente no 13 de maio de 1976. No dia oficial de comemoração da Lei Áurea, a turma de seminaristas "majoritariamente composta de descendentes de alemães e italianos" ${ }^{\prime 37}$ resolveu fazer uma brincadeira, na hora do almoço, com intuito de comemorar a data: "pegaram uma mesa, botaram no meio do refeitório e deram o toque do navio negreiro. E naquele dia os negros seminaristas deveriam sentar naquela mesa para almoçar." ${ }^{38}$ Uma atividade recreativa que a princípio não era vista por seus idealizadores como um problema; tinha apenas por intenção retirar a dramaticidade do evento histórico, deixando-o sem aquele tom carregado tão caro ao traço político dos poemas de Castro Alves. Na verdade, tratava-se de trazer à lembrança, de forma lúdica - e talvez jocosa - , a imagem da abolição via representação do navio negreiro, o qual deveria ser composto pelos prováveis descendentes da travessia do Atlântico. Mas mal sabiam que nem todos estavam dispostos a assumir o assento nessa embarcação:

\footnotetext{
E como eu nunca me imaginei negro, sempre me vi como alguém queimadinho da praia(...). Na verdade, eu nem tomei para mim a missão de sentar naquela mesa do meio. Sentei normalmente nas mesas laterais, como os brancos. E na hora da brincadeira alguém gritou: êpa, tem uma cadeira vazia. Falta alguém. É o David. ${ }^{39}$
}

Logo que notaram a ausência de David, pegaram-no "pelas pernas e pelos braços" e o colocaram na mesa do navio negreiro. E aquilo que era para ser apenas uma brincadeira de rememoração do 13 de maio tornou-se para ele o grande divisor de águas em sua vida. David interpretou a situação como uma exposição pública de sua pessoa: “Aquilo foi um grande insulto. Eu nunca tinha passado por isso em toda a minha vida: eles me chamaram de negro em público". ${ }^{40}$ Sua reação não foi outra: quebrou alguns objetos da mesa e saiu dali decidido a abandonar o seminário.

Dentre as várias possibilidades interpretativas desse evento, pode-se afirmar que ocorreu ali um choque de classificações raciais. Seus colegas chamaram-no de negro, quando David ainda não se identificava com tal classificação. Por conta desse confronto de representações, ele

\footnotetext{
${ }^{37}$ Entrevista de Frei David dos Santos concedida a Guimarães, 2001, p.543.

${ }^{38}$ Entrevista de Frei David dos Santos concedida a Alberti e Pereira, 2007, p.49.

${ }^{39}$ Idem, p. 50.

${ }^{40}$ Entrevista de Frei David dos Santos concedida a Guimarães, 2001, p.544.
} 
tomou aquela experiência como uma "violência racial". David sairia do seminário não fosse seu superior, "um alemão", como ele mesmo disse, tê-lo convencido do contrário. A orientação do formador era de que o seminarista perdoasse seus colegas e que observasse a sua própria conduta frente a sua origem racial. Em conversa com o formador, David hesitou em mostrar-lhe a foto do pai, revelando apenas a de sua mãe, que era branca. Intrigado com o fato de o jovem esconder a foto do pai, o superior, ao solicitar esse material, intuiu que ele poderia ter vergonha de sua ascendência negra ${ }^{41}$ :

Fui meio chateado, peguei a foto e dei-lhe. Quando ele a pegou, olhou e virou para mim. E começou a trabalhar o fato de que eu estava sendo vítima de uma doença muito grave, que contagiava a maioria do povo negro. Eu era vítima da ideologia do embranquecimento. Então fiquei chateado porque era um branco que estava falando isso para mim, senti humilhação, muito confuso (sic) e ficou complicado para mim aquela situação. ${ }^{42}$

Essa foi a versão contada a Contins numa entrevista realizada no ano de 1994 e publicada no ano de 2005. Uma narrativa muito semelhante fora também contada a Guimarães (2001). Em 2004, em entrevista cedida a Alberti e Pereira, encontra-se a mesma história, simulada em formas de diálogos, contrastando a posição de David e a de seu formador. Mesmo com algumas nuanças entre as três versões esse é o evento paradigmático exposto por David, quando questionado acerca do marco de construção de sua identidade negra. Não se sabe ao certo se essa foi a única situação de discriminação racial enfrentada por ele no seminário, não seria de estranhar que fosse uma dentre várias, já que esse evento aconteceu no terceiro mês de estadia naquela instituição de ensino eclesiástico. De qualquer modo, esse não é um problema que ocupa esta pesquisa. Interessa aqui apenas apreender o fato de que essa foi a experiência selecionada por ele para mostrar o ponto de inflexão de sua vida, capaz de torná-lo um militante da "causa negra".

Embora a narração de David relate uma experiência particular e tenha ocorrido no espaço específico da Igreja Católica, os elementos estruturais de seu discurso contêm formas típicas de ilusão biográfica (Burdieu, 1998) comuns à militância. É nesse sentido que utilizamos sua história pessoal para ilustrar a formação de subjetividades negras. Assim, temas como o trauma

${ }^{41} \mathrm{Na}$ entrevista que David concedeu a Guimarães (2001), ele conta esse mesmo evento. Há, contudo, uma informação adicional sobre seu pai: este teria abandonado a mãe e os filhos, que cresceram com muitas dificuldades financeiras, e eles tiveram na figura materna o alicerce econômico, social e educacional. (p.539)

${ }^{42}$ Entrevista de Frei David dos Santos concedida a Contins, 2005, p.154. 
da discriminação, a dificuldade de se ver como negro e a busca do conhecimento como saída para a alienação racial são comuns nas narrativas de diversas lideranças do movimento ( Contins, 2005; Alberti e Pereira, 2007).

A experiência de violência racial de David teria sido tão expressiva a ponto de ele decidir por uma ação pastoral voltada para a população negra? Estamos nitidamente diante de um processo em que a construção da identidade social encontra um ambiente externo relativamente favorável. Lembremos que tal experiência se processa nos derradeiros anos da década de 70, justamente os anos que a Igreja Católica passava a trazer em seus documentos passagens como aquelas transcritas a pouco nas páginas passadas. Não por acaso, o próprio formador de David foi quem o alertou sobre a ideologia do embranquecimento, interpretada por ele como uma doença que "leva a pessoa a rejeitar seu povo, sua raça, sua etnia"43. Esse alerta vindo do formador despertou em David um sentimento de humilhação, afinal de contas era um branco que estava dizendo para ele assumir uma identidade negra.

Não cabe, contudo, inferir da experiência de David um modelo para os demais seminaristas. Isso não impede, entretanto, a suposição de que os demais religiosos, ao decidirem por uma ação pastoral voltada para o negro, tenham lidado em algum momento com a sua identidade racial. Em seu relato, David já assinala a dificuldade de seus colegas em falar sobre o assunto. É plausível supor que os indivíduos que decidiram tornar-se, como ele, os Agentes da Pastoral Negros (APNs) não poderiam fazê-lo sem ter uma experiência subjetiva de apreensão dos novos significados atribuídos ao status público do ser negro.

No que toca ao caso aqui relatado, David convenceu-se de que a sua experiência era na verdade resultado de um problema da sociedade brasileira. Da posição de revolta e raiva (no primeiro momento da brincadeira) para a posição de humilhação (no segundo momento com o superior), David já conta a sua história mostrando uma tentativa de reconciliação consigo mesmo. Iniciava um processo reflexivo no qual uma característica adscrita passa a ter proeminência política em sua vida, tornando-se objeto de inquietação. Inquietação essa que o autor pensou resolver através de leituras e maior entendimento acerca da história do negro. Os processos psíquicos e emocionais vividos nessa experiência não nos competem investigar; não temos

\footnotetext{
${ }^{43}$ Entrevista de Frei David dos Santos concedida a Alberti e Pereira, 2007, p.50-51.
} 
instrumental para tanto. Por ora, cabe evidenciar que tal experiência desenvolveu em David uma certa disposição para agir coletivamente em favor da questão racial:

Em seguida, comecei a trabalhar esse fato, e ele tinha muita razão: eu estava sendo vítima de uma situação da sociedade. Decidi não mais ir embora, porém ler tudo que é livro sobre a questão do negro. Encontrei o primeiro problema ao vasculhar a biblioteca do seminário: a descriminação da estrutura contra nós. Existia livro sobre a cultura alemã, italiana, colonização italiana no Brasil(...) Havia livro sobre o que se imagina com preferência a povos, mas não encontrei nenhum sobre o povo negro. A partir dali começou a me intrigar esse fato, e começou a nascer em mim o desafio de dedicar minha vida a esta causa do povo negro ${ }^{44}$.

Não podemos deixar de notar uma passagem interessante na narrativa dele: os sentimentos de revolta/raiva e humilhação cedem lugar para a reflexão acerca da história do negro. Esse momento de reflexão, curiosidade e crítica abre-se para uma ação em favor de uma causa social. Ei-lo diante de um desafio pessoal de engajar-se em favor de um interesse coletivo. Esse relato indica que o homem decidido a dedicar sua vida a Deus e aos pobres, por conta do seu carisma religioso; agora se via diante do desafio de lutar em favor da "causa do povo negro". Em outra passagem, isso fica mais nítido: "Decidi que a partir dali não queria ser mais franciscano porque tem uma proposta de vida e uma proposta de sociedade. Eu queria ser franciscano porque eu queria botar essa estrutura de Igreja e de franciscano a serviço de um assunto que não é tão bem trabalhado, que é a questão do negro"45. Conta-nos David que durante dois anos viveu "um processo de busca de crescimento interior". ${ }^{46}$ Durante esse tempo, nascia nele um desejo de alterar a situação de "alienação" e de "negação" de suas origens, uma vez que este problema era compartilhado pelos demais seminaristas negros, como foi percebendo aos poucos.

\footnotetext{
${ }^{44}$ Entrevista de Frei David dos Santos concedida a Contins, 2005, p. 154.

${ }^{45}$ Entrevista de Frei David dos Santos concedida a Alberti e Pereira, p.51

${ }^{46}$ Entrevista de Frei David dos Santos concedida Contins, 2005, p.155.
} 


\subsection{As redes submersas}

Daquela experiência individual, David com seus colegas sacerdotes optaram por fazer atividades de reflexão acerca dos problemas raciais brasileiros. Logo depois, essa ação tomaria uma forma mais completa e abrangente, extrapolando os muros da Igreja e as fronteiras da filiação católica: "então comecei a sair, não para fundar um trabalho externo entre os seminaristas, mas com o povo, para fundar um núcleo negro" ${ }^{97}$. Para tanto, esses indivíduos recorreram às relações pessoais, de amizade e de lealdade, existentes no seu cotidiano, ou seja, as redes informais, indispensáveis à constituição de qualquer ação coletiva.

O núcleo mencionado é uma vertente do ativismo negro nacional organizado sob a sigla União e Consciência Negra (UCN). Este foi o primeiro grupo composto por civis e religiosos para trabalhar a questão negra no Brasil. Formalizado em Brasília no ano de 1980 e disseminado por vários estados brasileiros através dos religiosos negros, a UCN conseguiu abrigar ainda sob o regime da ditadura militar a mobilização negra de origem católica ${ }^{48}$. Segundo Bas'llele, “ela é fruto das reflexões do Vaticano II em combinação com Puebla e Medellín e não tem uma ligação genética com o MNU” (2005, p.129). Muito embora o Movimento Negro Unificado tenha sido a principal referência naquele contexto, influenciando o repertório de ação coletiva negra empreendida pelos ativistas, mesmo no meio dos religiosos ${ }^{49}$.

O UCN sofreu um racha logo no início de sua formação, dando origem aos Agentes da Pastoral Negros (APNs). Dessa primeira ruptura, entre "leigos" e eclesiais, surgem os APNs, afirmando sua filiação ao catolicismo, sem deixar a identidade racial, inaugurando nacionalmente uma forma de identidade negra combinada com a pertença religiosa cristã, desafiando, assim, o repertório do movimento negro unificado que secularizava os elementos sagrados das religiões de "matrizes africanas".

No calor da formação desse grupo pastoral, o teólogo Aldelino José Neto, um defensor dos APNs, sem se esquecer da abertura da Igreja para a temática racial após o Concílio do Vaticano II, considera que os religiosos negros enfrentavam os seguintes obstáculos: “o desprezo

\footnotetext{
${ }^{47}$ Idem, p. 155

${ }^{48}$ Vale dizer que na cartilha "'Ouvi o Clamor desse povo'... negro", os APNs apresentam dois grupos negros organizados e de amplitude nacional nos anos 80: o Movimento Negro e o União e Consciência Negra (p. 39).

${ }^{49}$ Um padre paulista entrevistado por Bas'llele confirma que o MNU era a inspiração para o UCN, em suas palavras "o MNU foi na época, sem dúvida, um movimento que despertou a União e Consciência Negra" ( Ver entrevista de APN a Bas'llele, 2005, p.129).
} 
pela memória do negro, o lugar marginalizado onde o negro se encontra, a presença do racismo e da ideologia do embranquecimento e a pretensa democracia racial" (Neto, 1986, p.137). Esta última, em sua opinião, ganhava roupagens religiosas.

Diante desses desafios, ao longo da década de 80, esses agentes desenvolveram duas estratégias de ação: uma no interior da própria igreja e a outra com a população negra e pobre. $\mathrm{Na}$ Igreja Católica, tentaram conscientizar e organizar os sacerdotes negros e influenciar as autoridades progressistas desta instituição. Um dos marcos dessa investida aconteceu em 1983, ano em que os ativistas negros decidiram realizar o primeiro encontro de religiosos, seminaristas e padres negros, no colégio de freiras chamado Assunção. $O$ fato é que esse evento foi proibido por Dom Eugenio Sales, um cardeal-arcebispo do Rio de Janeiro durante 30 anos, de 1971 a 2001. O encontro ocorreu, mas não sem o embate entre os frades e seus superiores, estes últimos pensaram mesmo em puni-los. Nesse conflito, alguns agentes da sociedade civil, como o IBASE, na figura de Betinho, interveio em favor dos religiosos negros.

A teologia da libertação foi o ideário religioso sobre o qual os ativistas dos APNs disputaram a representação do negro. Pelas frestas desse catolicismo renovado foram lançadas idéias e concepções do movimento negro. Estas foram traduzidas para o ideário religioso católico e vislumbradas pela encarnação de Jesus, isto é, a possibilidade de expressão de uma identidade negra cristã, porque o negro encarnava no presente a vida e a história do Cristo. Assim, os propósitos dos APNs seriam o "enegrecimento da teologia, da pastoral, das celebrações", estimulando um ecumenismo aberto e real"(Neto, 1986, p.144), tendo como prioridades "a comunidade negra e as expressões da memória do negro" (Idem).

Nos ministérios dos sacerdotes negros, a população pobre e negra é o principal desafio. Segundo o próprio David, o propósito era apresentar a "história do negro no Brasil, dando a eles a consciência histórica, porque entendíamos que a consciência é o primeiro passo para o despertar"50. Nesse período, os APNs desenvolveram atividades de "conscientização da comunidade negra" acerca de sua história e cultura. Nesse processo, a principal articulação era com o IBASE, na figura de Betinho, o qual contribuiu com a produção de materiais para o trabalho dos APNs. Por exemplo, eles colaboraram com a produção de slides educativos, como "A história que não foi contada" ou ainda "A vida renasce da luta". Nesse processo, o IBASE

\footnotetext{
${ }^{50}$ Entrevista de David Pereira dos Santos concedida a Albert e Pereira, 2007, p. 191.
} 
disponibilizou uma equipe para assessorar o trabalho desses agentes. Isso ocorreu porque David entendia que Betinho, além de ser seu amigo, tinha "uma consciência racial muito madura" ${ }^{\text {. }}$

Se os anos de 1980 são marcados pela disputa dos símbolos nacionais como diagnosticou Hanchard (2001 [1994]), os APNs não fugiram a isso. No ano que antecedeu o centenário da abolição, os sacerdotes negros do Rio de Janeiro elaboraram uma cartilha para a campanha da fraternidade do ano de 1988. Assim, um ano antes do centenário foi lançado um livreto direcionado "a todos os grupos de base como serviço à campanha da Libertação" 52 . Apesar de ser um texto de autoria coletiva, preparado pelos agentes da pastoral negros, coube a Frei David a elaboração da Introdução, o qual estrategicamente fez um discurso que tencionava a representação da Igreja frente ao movimento negro. Segundo ele, “a humildade e o desejo de pedir perdão que transparece na face da maioria de nossos pastores pelos pecados da Igreja de ontem contra o povo negro demonstra o quanto a Igreja está se auto-evangelizando, assumindo a causa negra hoje" ${ }^{, 53}$. Era, então, uma tentativa de estabelecer publicamente um compromisso com a questão racial, mesmo que os grupos compromissados não passassem de um segmento minoritário e inexpressivo na Igreja Católica. No entender do autor, essa iniciativa de abertura da Igreja poderia ser demonstrada tanto pela existência de um padre "para prestar serviço ao povo negro" 54 , quanto pela própria possibilidade de elaboração da cartilha a qual se deu graças a Editora Vozes, coordenada pela Ordem Religiosa Franciscana. Com isso, os recursos da Igreja já passam a ser mobilizados para atender as demandas materiais dos APNs. Mais do que isso, os símbolos da Igreja e suas narrativas sobre si recebem críticas e exigências de mudança.

Nesse sentido, a proposta dos religiosos negros para a campanha da Fraternidade foi a adaptação do versículo bíblico do livro dos Êxodos, “Ouvi o clamor desse povo... negro”. Ao acrescer o termo negro ao trecho extraído da Bíblia, os APNs entendiam que a Igreja responderia à realidade específica do país, bem como ao momento histórico do Centenário. Mas a Conferencia Nacional dos Bispos do Brasil decidiu pela proposta "Ouvi o clamor desse povo" (Gorender, 1991; Maggie, 1994). O que marca essa campanha pela fraternidade é a luta simbólica, elevada ao âmbito nacional, travada pelos padres e seminaristas negros organizados,

\footnotetext{
${ }^{51}$ Idem.

${ }^{52}$ Extraído do livro “'Ouvi o Clamor desse povo’... negro”, 1987, p.7

${ }^{53}$ Idem.

${ }^{54}$ Idem.
} 
que disputaram no interior da Igreja uma representação do povo. Seja porque o povo brasileiro é negro, seja porque o negro é a encarnação da pobreza no Brasil, na visão desses ativistas.

A experiência de um frade maranhense, que na época dos cem anos de Abolição era apenas um pretendente ao seminário, talvez ajude a apreender o impacto dessa discussão no interior da igreja católica:

Quando, em 88, eu conheci a irmã Paula, das irmãs Paulinas, e a Ana Paula era da campanha da fraternidade, então lá, foi a primeira vez que eu... tipo, me deparei com essa questão racial. Era uma negra, do Paraná, tinha sido transferida para São Luís, uma freira das congregações Paulinas. Nós estávamos dentro de um retiro de carnaval, e ela foi chamada para dar uma palavra sobre a campanha da fraternidade, e aí começou a refletir conosco, com os jovens que estavam no retiro e tal, mas já existia em São Luís grupos negros; eu que não tinha participado. Aí começou ali as primeiras reflexões, o primeiro despertar meu para essa questão da negritude... depois, eu comecei me tocar (...) Aí eu comecei a ter essas reflexões. A vantagem dessa irmã, é que ela abriu a reflexão que antes eu nunca tinha feito; com 16, 17 anos eu nunca tinha parado para refletir sobre isso. ${ }^{55}$

Nessa campanha, os APNs acompanharam as reivindicações gerais do movimento negro as quais tentaram apresentar uma nova face para o povo brasileiro, não mais o mestiço, e sim o negro. Nessa luta simbólica, os heróis nacionais foram negados em favor de personalidades negras do passado escravista. Numa linguagem popular, a cartilha revela alguns dos chamados falsos heróis que seriam Rui Barbosa, Domingos Jorge Velho, a Princesa Isabel e Duque de Caxias: primeiro pela queima dos documentos da escravidão; o segundo pela destruição dos quilombos dos palmares; a terceira por ter sido considerada a "redentora" dos negros; e o último por conspirar contra os negros egressos da Guerra do Paraguai. Em oposição, a figura de Zumbi dos Palmares é erigida como a representativa dos "verdadeiros heróis" da nação.

Um dos desdobramentos da distribuição dessa cartilha foi a proposta polêmica de retirar o nome "Duque de Caxias" de um dos municípios da Baixada Fluminense. Isso levou o movimento para mídia e causou muita desconfiança no exército (Gorender, 1991). Em 1988, os Agentes da Pastoral do Negro estavam envolvidos na construção da marcha pela falsa abolição, a qual foi duramente reprimida pela forças armadas. O que estava em disputa nesse evento foi justamente o receio de que os manifestantes estivessem dispostos a danificar o busto de Caxias. Esse evento é, particularmente, emblemático, pois mostra a tônica das ações do movimento negro

\footnotetext{
${ }^{55}$ Entrevista de Frei Evandro, fundador do Cursinho para Negros e Carentes em São Luis, concedida a mim, em
} setembro de 2006 
no Rio de Janeiro. Tratava-se da negação de certos símbolos nacionais e da tentativa de instituir heróis ligados à resistência negra. Essas ações foram flagradas por Hanchard, o qual considerouas incapazes de alterar as desigualdades entre negros e brancos, uma vez que esse tipo de luta estava no campo dos símbolos culturais, e não focalizando as formas e mecanismos discriminatórios que a sociedade encontrava para manter os negros em posição subordinada.

Nessa década, as atividades dos APNS frente às organizações eram ainda voltadas para a valorização da cultura negra e mantinham uma proposta de diálogo com outras religiões cristãs e afro-brasileiras como a Umbanda e o Candomblé. Uma das atividades mais marcantes desse período foi a realização do "Encontro ecumênico de teologia afro-brasileira", em 1989. Assim, na década de 80, predominaram as iniciativas de reflexão e conscientização de negros e brancos acerca da situação do preconceito e da discriminação racial. Especialmente, o trabalho de valorização da cultura e história negras ganhou proeminência, através das missas "inculturadas" ${ }^{56}$, dos seminários e dos eventos que buscavam diálogo entre os católicos e as demais religiões, tendo a questão racial o ponto de diálogo entre eles. Era a década de denúncia do racismo e da conscientização dos negros, de modo que essa era a forma de libertar-lhes da "alienação do embranquecimento".

Somente na década seguinte o movimento negro eclesial desenvolveria uma proposta de superação das desigualdades e discriminações raciais no Brasil, optando por um projeto de intervenção na área educacional, por entender que essa seria a via pela qual se processa a mobilidade social dos negros. Para isso, foi preciso ampliar as suas bases para além da igreja e dos fiéis católicos, sendo necessárias a articulação e as disputas com lideranças comunitárias e setores do movimento negro.

\footnotetext{
${ }^{56}$ As missas inculturadas são as formas pelas quais a Igreja Católica assinalou o processo de entrada numa dada cultura. O teólogo Neto (1986) faz uma defesa eloqüente acerca da inculturação nas práticas da pastoral do negro, em suas palavras “ a inculturação como processo que leva em conta o outro como ele é, sem acomodá-lo a uma cultura diferente da sua numa atitude colonialista, torna-se o ponto de apoio no tratamento que busca dar hoje à questão específica do negro no Brasil, através da organização de uma pastoral do negro inculturada. E inculturada porque busca conhecer o homem negro, como negro que é - portador de experiências e memórias históricas, culturais e religiosas que o identifica como negro e não como um embranquecido, como um subhomem marginalizada como um sem história”. (p. 141). As conseqüências da inculturação não recairiam apenas sobre o negro, mas sobre a própria Igreja, senão vejamos: "Deste modo, a Inculturação, a própria igreja, numa contínua presença de compromisso com o negro, vai se enegrecendo, buscando expressar sua catolicidade no modo mesmo através do qual ela se faz presente e inculturada nas experiências e expressões do homem negro". (p. 142).
} 


\subsection{A era dos projetos sociais}

Passados os tempos dos protestos e denúncias que marcaram os anos da democratização, no início da década de 90, os APNs decidem que não bastava somente intervir no plano da "conscientização racial", era preciso uma ação que pudesse mudar a vida concreta dos negros. Esse foi o entendimento do grupo eclesial, que tinha passado quase uma década desenvolvendo propostas de diálogo com a população negra e pobre da região da baixada fluminense, usando como estratégia a divulgação de informações acerca de sua história e cultura. Frei David, em 1994, faz a seguinte consideração em relação às práticas do movimento negro e a nova proposta de intervenção na Baixada Fluminense:

De um modo geral, estamos preocupados porque o movimento negro tem, ao longo da história, optado por um caminho muito da teoria e pouco do trabalho prático de base. Então, evitamos fazer trabalho com grupos que não tem atuação de base concreta ou que valoriza muito a teoria. Uma questão que se coloca sempre para as entidades negras do Rio de Janeiro é esta: quantas vezes vocês subiram os morros do Rio de JaneiroCantagalo, Rocinha Pavão etc para fazer um trabalho concreto com o povo negro? ${ }^{57}$

Estas preocupações com a "prática" não eram isoladas. A necessidade de se aproximar das comunidades negras de baixa renda também foi apresentada pelo grupo Afro-Reggae, como bem mostrou Cunha (2000), indicando um novo tipo de intervenção do movimento; agora mais próximos dos lugares de moradia da população negra. Na verdade, essa foi uma atitude tomada por um setor significativo do movimento negro, que ingressou os anos 90 com projetos sociais voltados para mulheres, jovens e crianças negras no campo da saúde, da educação, da cultura, do trabalho e dos direitos humanos ${ }^{58}$.

\footnotetext{
${ }^{57}$ Entrevista de Frei David Raimundo Santos concedida a Contins, 2005, p.157.

${ }^{58}$ Organizações como CEAP, Criola, Geledés e Ceert já são exemplos de novas iniciativas negras.
} 
Mesmo no seio do movimento negro eclesial já ocorrem ações nesse sentido. No caso de São Paulo, Bas'llele (2005) mostra que os APNs desenvolveram, através da figura do Padre Batista, uma organização voltada para o acesso e permanência de jovens negros no Ensino Superior. Criada em 1987, o Instituto do Negro Padre Batista já vinha desenvolvendo atividades de intervenção social na área de educação com pequenos grupos. De modo que a iniciativa da Baixada Fluminense não era um projeto original de intervenção social, pois já encontrava experiências nas quais poderia se espelhar.

Mas o movimento eclesial negro precisava também fundamentar ideologicamente sua ação, sobretudo porque a estrutura mobilizada era a Igreja Católica. Na tentativa de legitimar uma proposta que envolva o movimento negro e a igreja católica, bem como outras religiões cristãs, os agentes pastorais buscam referência no movimento negro norte-americano para dialogar com o repertório do movimento negro nacional:

\begin{abstract}
Acho fundamental que o movimento negro perceba que $90 \%$ das lideranças do movimento norte-americano nasceram nas igrejas cristãs em geral. Se você lembra o nome de qualquer líder negro norte-americano, vamos concluir que despertaram para a negritude na Igreja Luterana, na Igreja Batista. Portanto, acho que o novo negro no Brasil está nesse dado: os negros começam a empregar a tática de usar a estrutura das igrejas para fazer o processo crescer. Um outro dado também importante é que o povo negro sempre foi marcadamente da fé: sempre foi instrumento forte para todas as partes do mundo. O movimento negro brasileiro, ao longo de sua história, foi muito avesso à dimensão da fé. A fé do candomblé, a fé do protestante, a fé católica. O dado novo é que com o despertar da consciência negra dentro da Igreja católica, o movimento começou a despertar para a questão da fé ${ }^{59}$.
\end{abstract}

Essa passagem não deixa dúvidas de que esse movimento eclesial negro quis construir sua legitimidade frente ao movimento negro nacional, dialogando sobretudo como o MNU, que até a década de 80 exercia certa hegemonia ideológica sobre a militância negra e suas organizações. Não podemos perder de vista que o setor majoritário do movimento negro tem nas religiões de matrizes africanas suas principais fontes identitárias (Seyferth, 1983; Hofbauer, 2006). Ademais, apresentava críticas à igreja católica, seja por conta de seu papel de legitimadora da escravidão no passado, seja por conta da sua postura frente às religiões de matrizes africanas no presente ou ainda por conta das discriminações sofridas por negros sacerdotes, que não galgavam postos

\footnotetext{
${ }^{59}$ Entrevista de Frei David Raimundo Santos concedida a Contins, 2005, p.157
} 
elevados na hierarquia da Igreja. O fato é que o preço que os sacerdotes negros deveriam pagar para construir sua legitimidade frente ao movimento negro nacional não seria pequeno. $\mathrm{O}$ processo de negociação estava em curso e os conflitos também.

Estamos diante da tentativa de construção coletiva de uma identidade racial mais ampla, sem se restringir às religiões Afro-brasileiras. Se o leitor notar, perceberá de pronto que o discurso da liderança não nega a religião afro-brasileira. Ao contrário, trata-se antes de uma tentativa de alargar as bases do movimento social. Eis que temos uma estratégia aqui bem fundamentada na qual o movimento de base eclesial busca sua legitimidade no interior do movimento negro, ou seja, sem negar os fundamentos em que se sustenta.

Essa legitimidade não veio apenas da adoção de um discurso racial engajado. A intervenção direta nas comunidades periféricas dependeu de uma complexidade crescente das organizações negras e o surgimento gradativo de uma militância profissionalizada. Deve-se a esse processo de institucionalização o potencial para sustentar uma das bandeiras mais caras para o movimento negro na década de 1990: o acesso ao ensino superior. A Educafro é fruto dessa nova realidade civil.

O nascimento desta instituição remonta à formação, ao desenvolvimento e ao declínio da rede de pré-vestibular para negros e carentes (PVNC), iniciada em 1993, quando surge o cursinho voltado para a população negra e de baixa renda em São João do Meriti, na Baixada Fluminense. Sob a liderança dos agentes negros da pastoral católica ${ }^{\mathbf{6 0}}$, surge na região metropolitana do Rio de Janeiro uma iniciativa de base eclesial, cujo objetivo assemelhava-se ao projeto educacional modelo para o movimento negro, desenvolvido um ano antes na cidade de Salvador, o Steve Biko $^{61}$. O exemplo da Steve Biko foi inspiração para os demais cursinhos voltados para a população negra, como bem nota Henrique Cunha Júnior (2002) ao tratar da construção do Núcleo de Consciência Negra da USP formado um ano depois da Educafro, "a proposta de um cursinho pré-vestibular para negros é formulada nessa época tendo como inspiração a experiência do grupo Steve Biko" (Cunha Junior, 2002, p.24-25). Além da experiência baiana, a própria cidade carioca apresentava um modelo de cursinho pré-vestibular popular na

\footnotetext{
${ }^{60}$ Além da Pastoral do Negro, a formação do PVNC contou com a colaboração do GRENI, o grupo de reflexão religiosa dos negros e indígenas, a qual era ligada à Conferência dos Religiosos do Brasil. Esse grupo diferia dos demais porque para além de católicos, contava também com religiosos metodistas.

${ }^{61}$ Santos (2007) nos informa que o cursinho Steve Biko ficou conhecido na militância negra no encontro do Senun, o seminário de estudantes negros em 1993, na capital do Estado da Bahia.
} 
comunidade da Mangueira, o qual se diferenciava das experiências anteriores na cidade, porque alargava a dimensão de classe, construindo para si uma identidade de grupo social ou comunitária (Nascimento, 1999). A experiência da Mangueira, que surge em 1990, e o caso da Steve Biko serviram de modelo para a forma de intervenção que viria a se desenvolver no Rio de Janeiro durante essa década, cuja expressão atingiu um caráter de movimento social pela educação superior, na tentativa de abrigar sob a mesma bandeira as identidades de classe e de raça (Santos, 2007).

A Igreja Católica foi a principal estrutura utilizada pelo PVNC, isso porque "os negros começam a empregar a tática de usar as estruturas das igrejas para fazer o processo crescer”, na avaliação de Frei David, uma das principais lideranças do movimento. Essa era, pois, o projeto eclesial do movimento. Contudo havia nitidamente dois projetos em disputa no processo de construção da rede de pré-vestibular para negros e carentes. De um lado, lideranças leigas defendiam um projeto autônomo em relação à Igreja, que pudesse disputar recursos em parcerias com outras instituições, com franca ideologia de caráter popular. De outro, havia um projeto que defendia a combinação entre o popular e o racial, tendo como estrutura a Igreja católica, como nos conta o geógrafo Renato Emerson dos Santos:

Para uns era (ou, deveria ser) uma iniciativa no seio da militância católica racial - uma iniciativa dos Agentes de Pastoral Negros; para outros, era (ou, deveria ser) uma iniciativa no campo da educação popular, que havia se iniciado no seio da militância católica mas que não era necessariamente circunscrita à sua lógica, podendo (e, devendo) assumir outros formatos e estabelecer outros diálogos preferenciais e ideologias fundantes (2007; p.237-238.)

Essas duas concepções permearam o movimento desde o início ${ }^{62}$. Ao longo dos anos 90, a liderança católica construiu sua hegemonia e isso aconteceu sobretudo porque esta mobilizou uma estrutura bastante eficiente: os recursos materiais e simbólicos da Igreja. A rede de contatos institucionais das lideranças eclesiais foi fundamental para a construção do primeiro núcleo prévestibular, que foi organizado na Igreja Matriz de São João do Meriti com uma turma que iniciou

\footnotetext{
${ }^{62}$ Um dos ativistas contatados por Frei David para atuar nos núcleos fez uma declaração elucidativa acerca dessas disputas que levaram à construção da identidade do movimento PVNC. "(O PVNC) só tornou-se Pré-Vestibular para Negros e Carentes quando o David percebeu que as condições estavam dadas. Estavam dadas para ter no mínimo aquela identidade vinculante a um mundo racializado. Afora isso, certamente não entraria. Seria"Pré-Vestibular da Cidadania", ou "Pré-Vestibular Popular da Baixada". Seria um nome assim difuso, e aí seria muito difícil você sustentar uma luta com essas características". (ativista negro Juca Ribeiro apud Santos, 2007, p.247).
} 
com aproximadamente 98 pessoas e terminou com 50 estudantes. No ano subseqüente, com aumento da procura (cerca de 716 pessoas inscritas para 150 vagas disponíveis no pré-matriz) foi necessário criar mais núcleos. A maior parte dos núcleos estabeleceu-se em igrejas ou espaços em que as lideranças eclesiais tinham influência ${ }^{63}$.

A influência dos eclesiais não pára na alocação de espaços para a realização dos cursinhos. Também o acordo dos primeiros convênios com as universidades privadas deveu-se à legitimidade da Igreja e sua rede de estabelecimentos de ensino superior. Através dos contatos dos líderes religiosos, houve o primeiro convênio com a Pontifícia Universidade Católica do Rio de Janeiro (PUC/RIO), uma instituição de prestígio, que deu maior legitimidade ao movimento, garantindo-lhes a divulgação dos cursos na mídia, o que impulsionou número de inscrições para o ano subseqüente. Da primeira turma, 4 estudantes ingressaram na PUC/Rio pelo sistema de bolsas integrais, no ano de 2003, quase uma década depois, essa instituição universitária contabilizava o saldo de 565 bolsistas provenientes da rede de pré-vestibulares liderada por Frei David (David dos Santos, 2003, p.1256).

Ao longo da década de 90, é possível perceber o aumento da demanda e a difusão do movimento de pré-vestibular para negros e carentes no Rio de Janeiro, revelando a necessidade dessa forma de intervenção civil no seio das comunidades negras e de menor renda. O que se nota, no entanto, é que a demanda crescente por vagas no ensino superior aconteceu justamente na década em que houve a expansão do ensino superior privado, em detrimento da expansão do ensino superior público (Guimarães, 2003). Uma das conseqüências mais interessantes para o nosso caso é que o investimento governamental no ensino superior privado levou a formação de vagas ociosas, especialmente em cursos de baixo prestígio social, para os quais se dirige boa parte dos estudantes provenientes do PVNC. É exatamente nesse contexto que essa rede de prévestibulares estabelece convênios com as instituições privadas de ensino superior. O geógrafo Renato Emerson dos Santos (2007) fez uma representação gráfica do crescimento dos núcleos do PVNC, desde a sua formação até seu declínio:

\footnotetext{
${ }^{63}$ Os espaços em que os núcleos se estabeleceram no segundo ano foram basicamente estabelecimentos religiosos cristãos, a maior parte católicos :Nilópolis (na Igreja Nossa Senhora Aparecida), Rocinha (no Rio de Janeiro, na Igreja Metodista), Prainha (na Creche Menino Jesus, das Irmãs Franciscanas, na comunidade da Prainha, em Caxias), Pastoral da Juventude ou PJ (na Catedral do Centro de Caxias) e Metodista (no Colégio Metodista no Centro de Caxias). (Ver Santos, 2007 p. 241).
} 


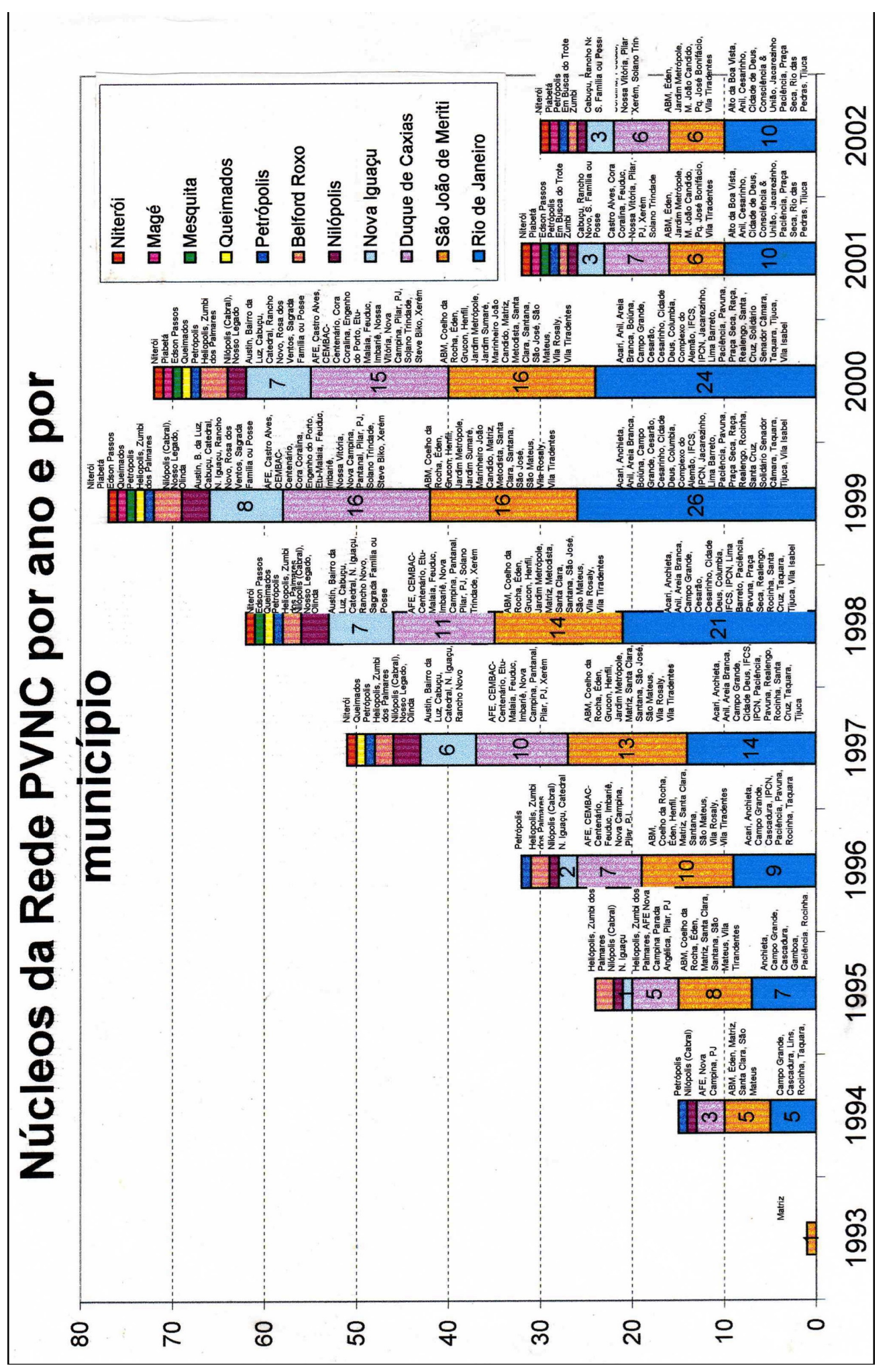


O declínio do PVNC está diretamente relacionado à cisão no seio das lideranças, levando os líderes eclesiais a formar a Educafro no ano de 1997. No início, esta organização funcionaria apenas como uma rede articuladora dos núcleos do PVNC. Entretanto, muitos núcleos do PVNC foram absorvidos pela Educafro a partir de 2000, a qual já apresentaria um movimento autônomo. Para os anos de 2007/2008, a Educafro do Rio de Janeiro contabilizava cerca de 55 cursinhos, concentrados na Baixada Fluminense e na cidade do Rio de Janeiro. Uma das conseqüências da formação da Educafro foi a maior expansão da rede pré-vestibular no território carioca, concorrendo com o número de núcleos da Baixada Fluminense. Vejamos essa distribuição ${ }^{64}$ :

Mapa de localização dos núcleos do Educafro na Região Metropolitana do Rio de Janeiro

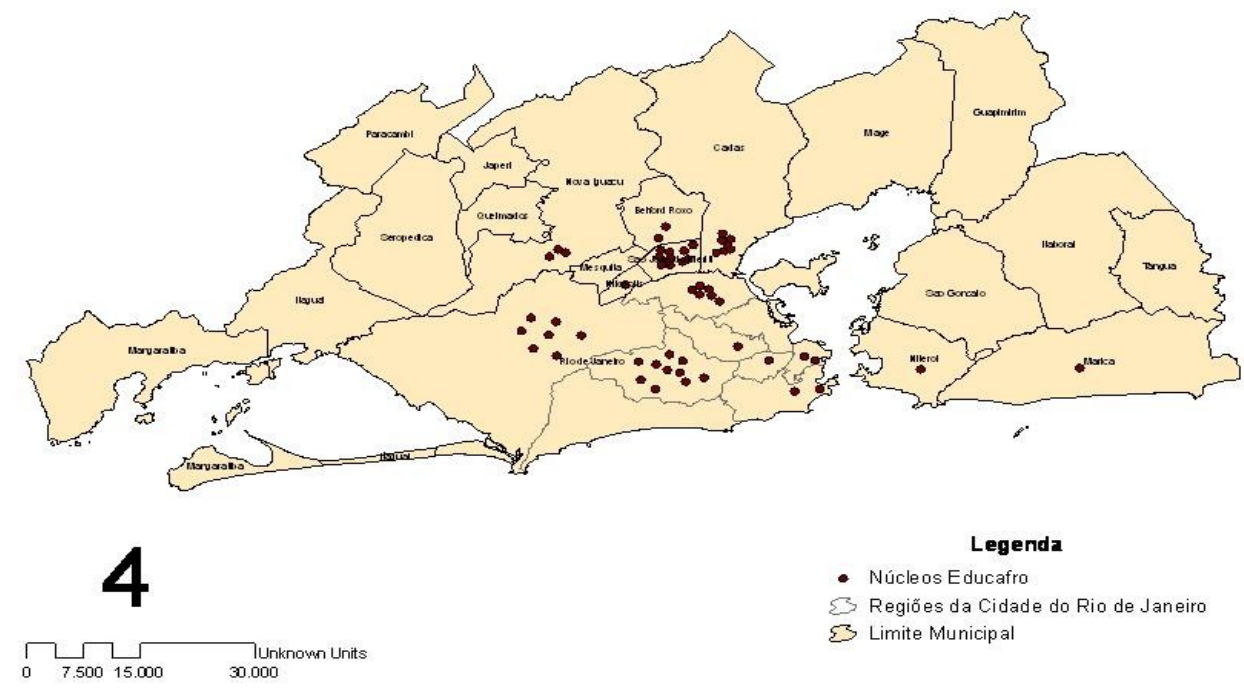

${ }^{64}$ Rogério Gutierrez Gama, estudante de pós-graduação na Escola Nacional de Estatística (ENCE/IBGE) elaborou gentilmente este mapa para esta dissertação. 
Embora a baixada fluminense ainda mantenha boa parte dos núcleos da Educafro, a construção de uma sede regional na cidade do Rio de Janeiro pode ter favorecido a maior capilaridade dessa organização neste município, que, no ano de 2007, contabilizava cerca de 30 núcleos, contra 25 resultantes do somatório das demais cidades fluminenses (ver tabela 1 e 2 dos anexos).

\subsection{A reprodução do movimento}

No início, o público da igreja católica foi um dos principais alvos das lideranças eclesiais. De acordo com uma das integrantes da segunda turma do cursinho, de 1994, a divulgação do projeto acontecia nas missas: “(...) porque havia missas 'inculturadas' que muitos amigos meus participavam, e aí comentaram nessas missas a inscrição para um pré-vestibular. E começaram a contar, um passa para o outro (...). Então, eu fui e fiquei." ${ }^{\prime 5}$ Essa foi a experiência de Célia, que se tornou estudante da Educafro e, depois de duas tentativas de ingresso no ensino superior, consegue entrar na Universidade Estadual do Rio de Janeiro, a Uerj, em 1995.

Já como estudante universitária, Célia, que antes da Educafro já militava em movimento popular católico, passa a gerir com seus demais colegas o cursinho de onde saiu anos antes. Devido às dificuldades de deslocamento, ela logo percebeu que poderia abrir um núcleo mais próximo de sua casa. Foi quando abriu o núcleo de Realengo. A estrutura para manter o espaço exigia engajamento social e alianças construídas com amigos e pessoas mais próximas; as dificuldades eram de toda ordem:

o início foi complicadíssimo. A gente conversou com escolas, a associação de moradores, até a gente se instalar durante três meses a gente andava. A gente tinha que deixar cartaz no CIEP."hoje a aula não será possível aqui, atravesse a avenida Brasil e vamos para o Brizolinha", é menor, é uma escola de educação infantil. Aí chegava outra semana:" aula não será aqui. Será na associação de moradores da irmã Cláudia". Que é presidente da associação, que é evangélica e tá lá até hoje, a irmã Claudia. Então a gente

\footnotetext{
${ }^{65}$ Entrevista concedida a mim em Duque de Caxias, em junho de 2006.
} 
fazia isso até que resolvemos sair do local fomos para Magalhães Bastos, num CIEP ${ }^{66}$, está lá até hoje ${ }^{67}$.

O que marca essa iniciativa é o caráter solidário dos agentes, o que é altamente estimulado pelas lideranças do PVNC. Fazia parte das recomendações do PVNC a construção de redes solidárias capazes de reproduzir a metodologia de formação dos núcleos, o que foi reproduzido anos mais tarde com a criação da Educafro, em São Paulo. O estímulo ao trabalho comunitário dos universitários e vestibulandos é a marca registrada desse movimento, e a forma pela qual ele consegue se reproduzir. Durante a passagem nos núcleos, os estudantes experimentam uma vivência de solidariedade entre os grupos, despertando nas pessoas a solidariedade para com os outros estudantes que anseiam ingressar no vestibular. A metodologia de reprodução dos novos núcleos buscava seguir o modelo da matriz:

foi uma coisa bem estrondosa. Por que estrutura permite se você vai divulgando a metodologia, passo a passo, do que você precisa saber para abrir o núcleo, você monta. Mas não é fácil fazer esse trabalho porque as pessoas são voluntárias...O difícil é manter-se por que os professores acabam, de uma certa forma, saindo. Muitos são estudantes ainda estão em processo de formação; então é mais complicado para se manter.

Certamente, a precariedade dos núcleos era visível. Não são raras as vezes que os entrevistados falavam da falta de recursos para criar e mantê-los. O espaço físico e o corpo docente eram os obstáculos maiores a serem enfrentados. Muita força de vontade e poucas possibilidades eram os elementos que marcavam a experiência do curso pré-vestibular. Yvonne Maggie (2001) deixa suas impressões de uma visita feita ao pré-matriz, onde tudo começou:

Numa rua íngreme em um bairro de periferia do Rio de Janeiro vislumbra-se uma igreja simples, situada no centro de um pátio e ladeada por uma casa paroquial e um galpão improvisado, que abriga uma sala de aula pouco arejada, cuja única janela dá para a sala da casa paroquial. Não há biblioteca e apenas alguns livros e revistas doados se acumulam na pequena copa ao lado do banheiro. Durante as aulas o professor faz um grande esforço para se fazer ouvir, porque ao mesmo tempo o coral da igreja ensaia e há jovens envolvidos com a organização de uma festa junina no pátio. Fiéis reunidos na casa paroquial discutem assuntos variados e o som se espalha pela sala de aula contígua. Nessas condições, os alunos se esforçam para ouvir as palavras do professor em aulas de matemática, geografia, português ou cultura e cidadania ( p.193).

${ }^{66}$ Os CIEPs são escolas públicas construídas no governo Brizola, chamadas popularmente de 'brizolões'. Tratava-se de escola na base do modelo construtivista.

${ }^{67}$ Entrevista de Célia concedida a mim em Duque de Caxias, em junho de 2006. 
Apesar da precariedade dos núcleos e da ausência de professores, o movimento por educação não parou de crescer. Um dos exemplos disso é a própria Célia que esteve nos primeiros anos de formação do PVNC, na construção de núcleos e na coordenação da sede regional da Educafro no Rio de Janeiro, atuando no setor de políticas públicas. O caso de Célia não é isolado. Todas as trajetórias dos coordenadores da sede regional do Rio de Janeiro no ano de 2006-2007-2008 estão ligadas aos núcleos de base, com trajetórias parecidas com a dela. A grande maioria das pessoas que atua na sede da Educafro era na verdade oriundos dos núcleos, o mesmo acontece para o caso de São Paulo. Com experiência em docência e coordenação do núcleo, os ex-estudantes são aqueles que devem retornar para contribuir com as novas turmas que se formam. Portanto, essa forma de reprodução social foi desenvolvida durante toda a existência do PVNC e foi transportada para a Educafro, transformando-se no alicerce de sustentação do trabalho voluntário, base material e ideológica que sustenta os núcleos. 


\subsection{A Educafro em São Paulo}

Depois da cisão com o PVNC, os eclesiais negros fundaram a Educafro no município de São Paulo, em 1997, nas dependências da Província Franciscana, a qual já abrigava pequenas atividades voltadas para jovens negros. Naquele ano, começaram com apenas um núcleo, mas no seguinte já contabilizavam cerca de 19 iniciativas. Esse crescimento, confirmado nos anos seguintes, exigiu maior complexidade administrativa, tornando a entidade cada vez mais institucionalizada:

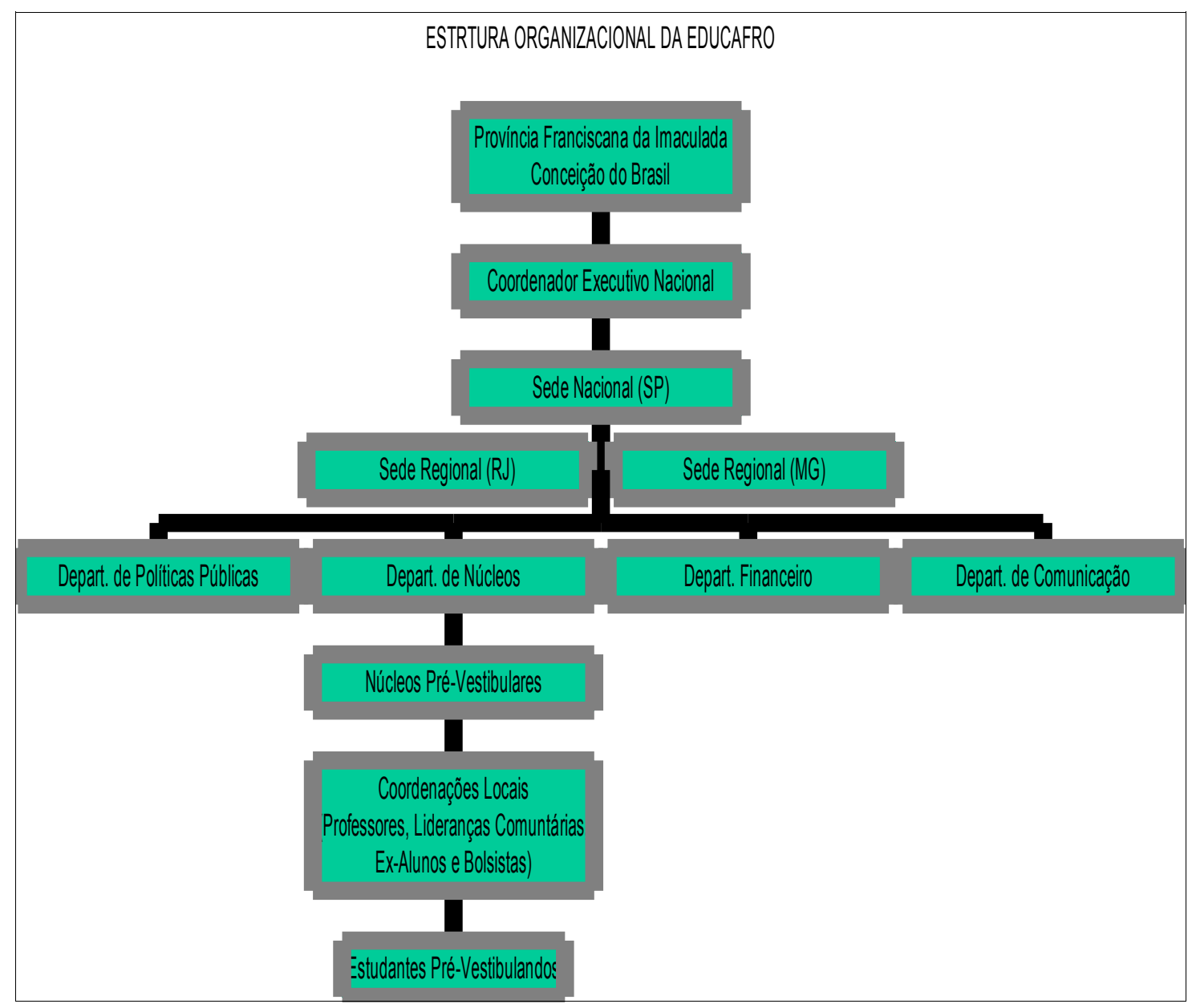

A Província Franciscana é a grande mantenedora da organização, o que desobriga a entidade de buscar recursos com outras instituições financeiras, como ocorre com diversas ONGs 
negras $^{68}$. A estrutura física que abriga as sedes da Educafro é propriedade dessa ordem religiosa. Os departamentos são geridos por funcionários contratados pela Província Franciscana, que também responde juridicamente pela Educafro. Além do poder econômico, a província tem o poder de nomear o representante executivo, que sempre foi um frade. No começo, Frei David ocupou esta posição, devido ao seu carisma e destaque como liderança no movimento educacional do Rio de Janeiro. Ademais, era um dos principais fundadores da organização. Com sua saída, em 2006, a posição de decisão da Educafro ficou nas mãos de outros frades nomeados pelo Conselho dos Franciscanos.

Abaixo do coordenador executivo, existe uma coordenação nas sedes que são disponibilizadas para lideranças construídas na organização, sobretudo aquelas que já passaram pelos núcleos e possuem trajetórias comprovadas de compromisso. Para além dos compromissos, a fidelidade e a proximidade com as lideranças eclesiais são requisitos que determinam a possibilidade de acesso ao posto de coordenador da sede, seja na regional ou na nacional. $\mathrm{Na}$ verdade, apesar da coordenação parecer um cargo político, a figura que ocupa esse lugar deve apresentar um perfil de gestor, uma vez que terá que gerir o andamento cotidiano da organização. Isso porque as decisões políticas mais importantes são realizadas pelo coordenador geral.

No que se refere ao coordenador geral, cabe uma nota: a figura de Frei David é emblemática na Educafro. Mesmo com sua saída oficial da coordenação geral, este líder é consultado na tomada das decisões importantes. Como liderança carismática, a sua figura se confunde com a imagem da organização, de modo que os coordenadores que o substituíram não foram capazes de suplantar essa representação. Assim, as decisões passam pelo crivo dele, mesmo estando a quilômetros de distância das cidades do Rio e de São Paulo ${ }^{69}$. Conectado diariamente com as sedes da Educafro, o frade conversa todos os dias com seus coordenadores, orientando-os nas decisões. Aqui, a Internet é o principal meio de comunicação que permite a onipresença dessa liderança religiosa, que, ademais, representa a entidade nos principais encontros que envolvem as políticas públicas negras do Brasil e no exterior. Os grandes eventos

\footnotetext{
${ }^{68}$ Diferentemente da Educafro, a maior parte das ONGs do movimento negro não possui fonte financiadora fixa. Por conta disso, elas precisam captar recursos de agências internacionais, de empresas privadas e de órgãos estatais.

${ }^{69}$ Frei David vive hoje no Estado de Santa Catarina. Por motivos de saúde, o Frei afastou-se do posto de coordenador executivo da Educafro em 2006.
} 
de visibilidade cabem somente a ele, que opina também sobre a escolha dos coordenadores de sede.

Depois da coordenação, os departamentos administrativos são o espaço-chave para a operacionalização da Educafro, destacando-se o setor de políticas públicas e o de núcleos. No primeiro, encontramos as relações de convênios e lutas por acesso ao ensino superior no Brasil, sobretudo através de protestos e dos meios jurídicos (o que veremos em tópico a seguir). No caso do setor de núcleos, vemos o trabalho de uma equipe profissional que faz a gestão dessas unidades distribuídas, sobretudo em São Paulo e Rio de Janeiro. São eles que promovem as reuniões de acolhida dos novos estudantes ou coordenadores de núcleos. Compete ao setor de núcleos visitar os cursinhos localizados em diferentes distritos e municípios, nos quais realizam a atividade de "avivamento dos núcleos". A seguir mostra-se a distribuição dos núcleos no Estado de São Paulo, considerando a especificidade da capital.

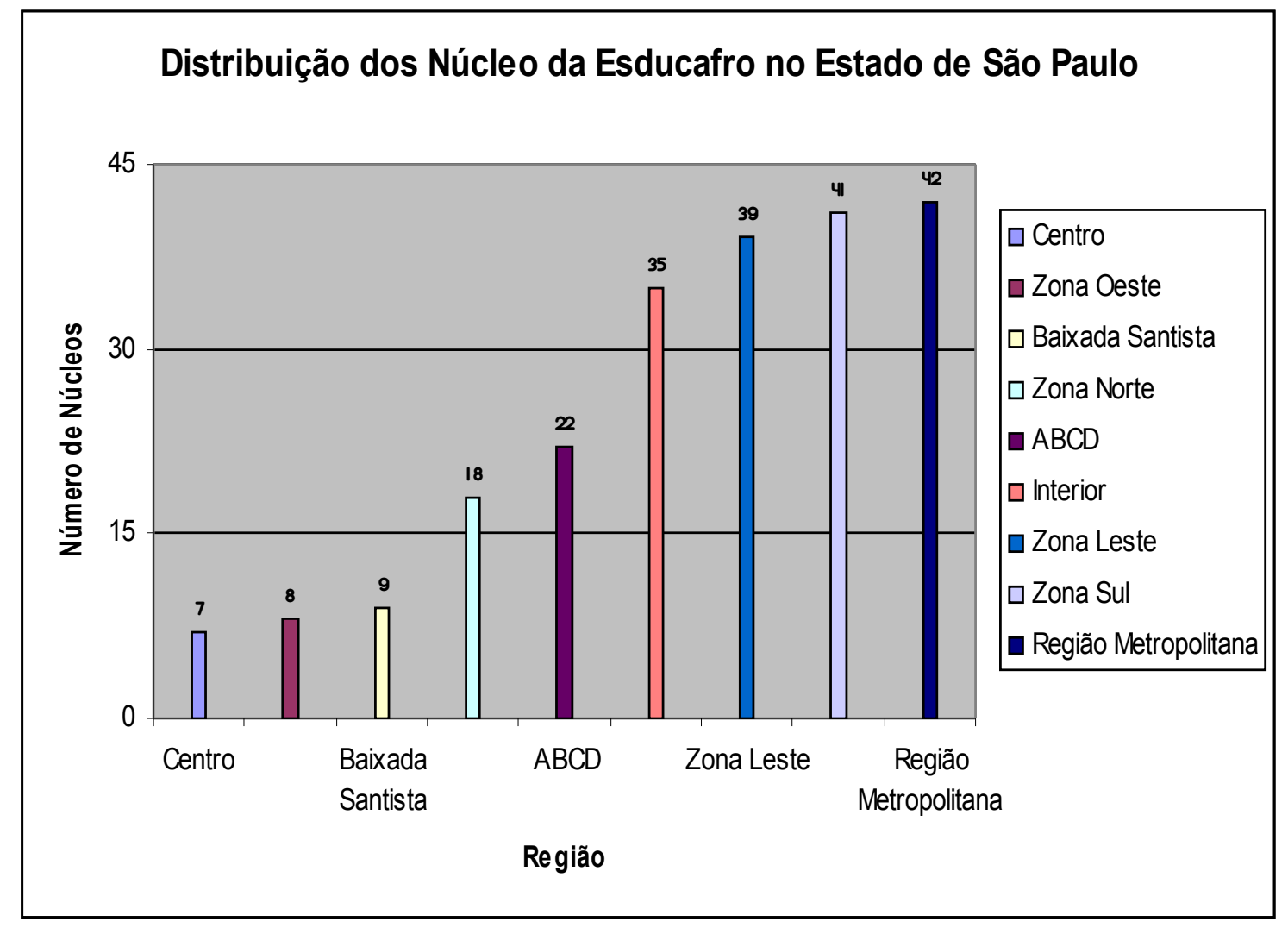


Os estabelecimentos públicos e as instituições religiosas são os principais espaços onde atuam os núcleos da Educafro, assim como fora na experiência dos PVNC no Rio de Janeiro. Nas igrejas e nas escolas públicas estaduais e municipais, reúnem-se cerca de 40 estudantes com uma equipe de 5 coordenadores. As aulas preparatórias para o vestibular acontecem nos finais de semana, preferencialmente nos sábados, com menos freqüência aos domingos. Em geral, os cursos não acontecem durante a semana, somente em casos muito raros isso se processa; quando isso ocorre os núcleos abrem dois dias semanais, durante à noite.

Até pouco tempo atrás, cada núcleo encaminhava para a sede o valor de um real por estudante. Mas na atualidade, não há repasse de verba para a organização central da Educafro. Esta organização trabalha agora com o modelo de franquia social, uma proposta que oferece maior autonomia aos núcleos, muito embora esses devam várias obrigações a sede nacional, como freqüências nas reuniões, lista de presença, relatórios de ocorrências nos núcleos. Ademais, a organização não aceita que os núcleos recebam financiamento de qualquer ordem e os bolsistas são ligados diretamente à sede, pois é do coordenador geral que recebem as cartas de recomendação e de revalidação de bolsas.

Com efeito, a Educafro não é uma organização desprezível em termos de potencial mobilizador. Seus mecanismos institucionais e alianças permitem canalizar as demandas sociais com alta eficácia política. O mapa abaixo revela o quão expressiva é sua atuação na cidade de São Paulo, relevando também que os núcleos da Educafro estão concentrados no entorno de áreas mais pobres, haja vista que seus estudantes oferecem uma pequena contribuição simbólica (cerca de $10 \%$ do salário mínimo) para a Entidade e passam por um processo seletivo de caráter socioeconômico para ingressar no núcleo e posteriormente para receber bolsas nas universidades privadas. Ademais, a esmagadora maioria dos estudantes é oriunda de escola pública, mesmo porque este também é um critério de ingresso no cursinho. 
MAP.2. Distribuição dos núcleos da Educafro, localização de favelas e concentração de domicílios com renda per capita até 1 salário mínimo, município de São Paulo, 2000.

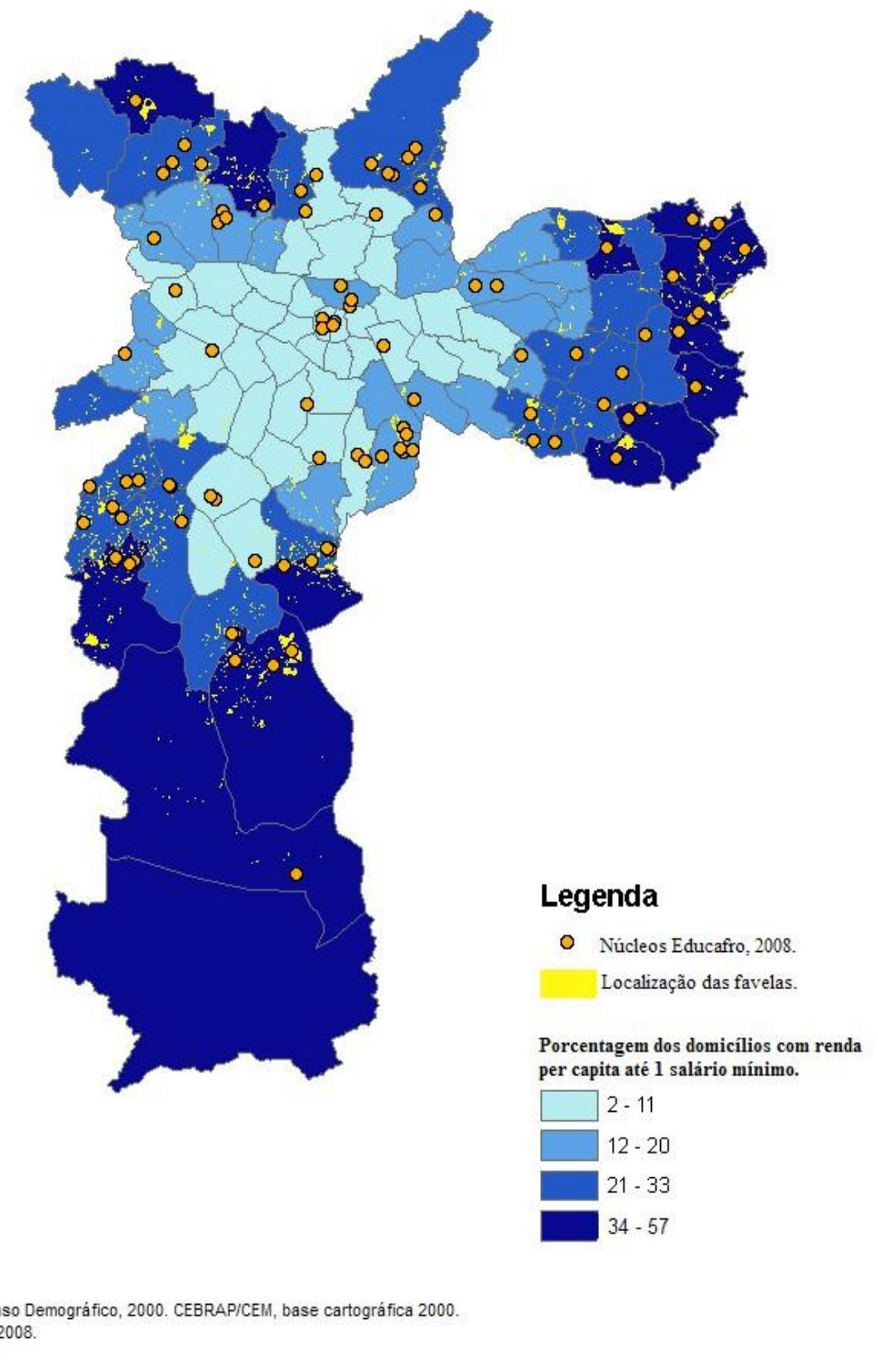




\subsection{A institucionalização e as formas de pressão social}

Desde o final da década de 90, a Educafro investiu intensamente numa equipe de advogados, transformando-a em assessoria jurídica. No começo, eram apenas alguns advogados convidados a discutir formas e estratégias de intervenção jurídica em favor da população negra. Com o passar do tempo, perceberam que o recurso jurídico surtia alguns efeitos positivos, porque abria espaço para negociação, assim a intervenção via Ministério Público tornou-se uma das ferramentas fundamentais da organização. Com isso, funcionários com formação em Direito figuram com destaque no quadro administrativo da Educafro, especialmente no setor de políticas públicas.

Com efeito, o recurso ao Ministério Público veio a ser uma das principais armas dessa organização e demais entidades do movimento negro, pois com isso poderiam não só denunciar as instituições públicas, como também poderiam aproveitar a ação judicial para dar visibilidade às suas demandas na mídia. Não são raras as vezes em que, ao denunciar um órgão público, a Educafro notifica sua investida jurídica à imprensa. Tudo se passa como se o Ministério Público, ao acolher a demanda da organização, emprestasse maior legitimidade pública para a causa em litígio.

As demandas da Educafro nas últimas duas décadas seguem diretamente a proposta geral do movimento negro, isto é, a luta por acesso ao ensino superior. A Educafro, nesse sentido, tornou-se uma organização especializada nesse tipo de reivindicações, figurando entre as organizações de maior destaque nos processos reivindicatórios da luta por ações afirmativas nas universidades. Um caso parece ilustrativo para demonstrar o foco e o perfil de ação da Educafro. Tomaremos a luta por isenções nas taxas de vestibular no estado de São Paulo. Veremos que o recurso ao Ministério Público sempre foi um meio utilizado pela organização. Esse caso nos ajuda a entender como a organização se mobiliza e lida com as instituições e autoridades, pois o padrão costuma ser o mesmo. Observaremos a luta por isenções, por meio das cartas e processos encaminhados pela Educafro. 
Num dos registros encontrados nos arquivos do ano de 2000, vê-se a seguinte declaração do mandado de segurança para a garantia de isenção de taxa do vestibular para estudantes pobres oriundos de escola pública. Segue abaixo a estratégia argumentativa:

A busca da guarida do Judiciário foi a última maneira encontrada para garantir o direito aos impetrantes de disputarem em condição de igualdade o ingresso em uma das mais conceituadas Universidades do Brasil. Antes desta medida extrema, muitas foram as tentativas de negociação, na busca de uma sensibilização das impetradas. Infelizmente tais negociações não lograram nenhum êxito ${ }^{70}$.

Esse mandado de segurança não vem desacompanhado de atos públicos e de negociações com fundações e órgãos universitários. As instituições públicas referidas no processo, precisam responder às denúncias e requisições feitas pelo Ministério Público, o qual por sua vez envia a resposta para a organização reclamante. Esses documentos oficiais não dispensam telefones, cartas menores, reuniões e conversas de corredores que marcam a interação face a face (ou uma operação corpo a corpo) dos agentes e constrangem os representantes dos órgãos governamentais, levando-os a agilizar o processo. O resultado desse esforço costuma resultar em audiência pública, e vem acompanhada de alguma nota na grande imprensa.

Lutas organizadas em torno de uma causa não vêm desacompanhadas de outras organizações civis. No caso das lutas por isenções, a Educafro alia-se a muitos outros movimentos por ensino superior. Por exemplo, em São Paulo o Movimento Sem Universidade (MSU) é um dos aliados de atos públicos. No ano de 2000,a luta resultou, para o caso da USP, em 5.000 isenções. No ano seguinte, utilizando dessa mesma estratégia, as isenções dobraram. Vê-se que ao perceberem as oportunidades abertas, as organizações buscam ampliar o seu alcance.

No dia 10 de setembro de 2002, a Educafro envia uma carta ao Ministério Público estadual na qual ela conta uma pouco de seu histórico e apresenta o argumento central em favor do qual escreve ao ministério:

Uma das principais barreiras encontradas pelos pobres tem sido a exigência indiscriminada do pagamento da taxa do vestibular, penalizando-os e excluindo-os antecipadamente de disputarem uma vaga no Ensino superior público. ${ }^{71}$

\footnotetext{
${ }^{70}$ Carta ao Ministério Público, em 2000.

${ }^{71}$ Documento enviado no dia 10 de setembro de 2002.
} 
Nessa carta, a entidade apresenta um histórico da organização, dizendo que estabeleceu contatos com os Centros Tecnológicos Públicos e nas universidades Estaduais e Federais. Mas, segundo o mesmo documento, não obtiveram êxito, de modo que foram obrigados a abrir "um total de 49 processos (mandados de segurança) contra a USP e Fuvest. O pedido desse documento é para que o Ministério Público acione (recomende) a USP e a Fuvest, bem como o Governo do Estado e a Secretaria de Ciência e Tecnologia, Desenvolvimento Econômico e o Turismo para que elas "determinem que a taxa de isenção do vestibular /2003 seja concedida a todos os estudantes que solicitaram, e não foram ainda contemplados". ${ }^{72}$

Na mesma carta, foi enviado o histórico da organização, bem como uma tabela acerca da baixa presença de estudantes egressos de escolas públicas na Universidade de São Paulo. No argumento, apresentam a experiência do Rio de Janeiro, a qual deveria ser seguida pelo Estado de São Paulo. Segue abaixo a transcrição da informação :

Acreditamos que o Estado de São Paulo deve basear-se no Estado do Rio de Janeiro em que todos os alunos da rede pública têm a isenção da taxa das Universidades Públicas. A mesma linha seguiu o Governo Federal que, por portaria, isentou os alunos da rede pública brasileira da taxa do Exame Nacional do Ensino Médio ${ }^{73}$.

O Ministério Público recebeu muitas ações com esse conteúdo. Pelo menos desde 1999 a Educafro encaminha petições para esse órgão público solicitando gratuidade das taxas dos vestibulares para estudantes oriundos de escolas públicas e com baixa renda. As fundações e instituições universitárias reagiram as essas demandas e muitas prestações de conta ao Ministério Publico foram encaminhadas cordialmente pelas instituições públicas, buscando esclarecer a situação. No gráfico abaixo, podemos ver um quadro evolutivo da resposta de uma das mais poderosas fundações universitárias do Brasil, a Fuvest:

\footnotetext{
${ }^{72}$ Idem.

${ }^{73}$ Idem.
} 


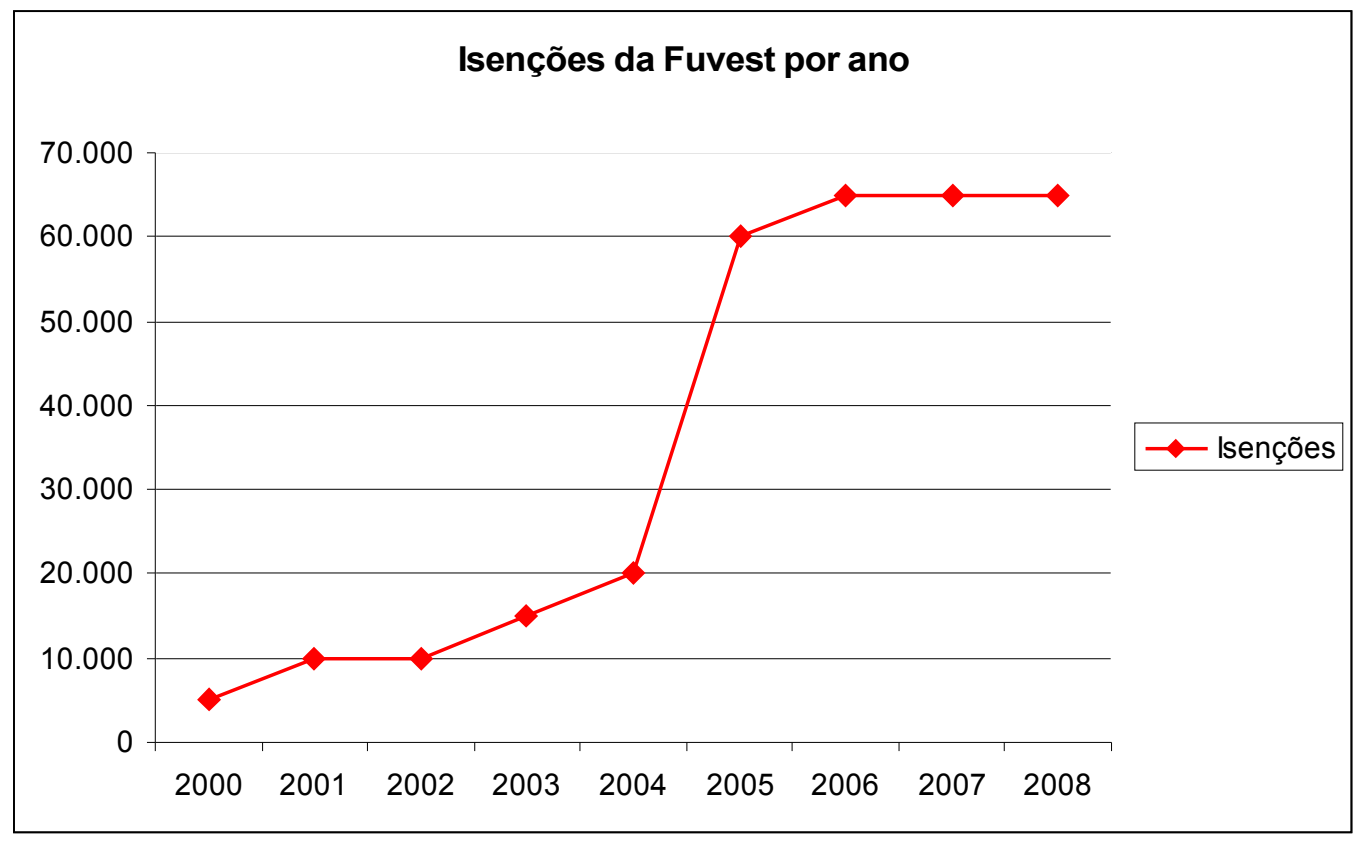

* Fonte: dados obtidos no Site da Fuvest

Esse êxito reivindicativo relaciona-se ao processo de institucionalização do movimento negro. Sem a acessória jurídica eficaz, as alianças com outros movimentos (como o MSU), a organização dos protestos, a burocracia interna da entidade e a ampliação dos canais de acesso ao Estado seria ainda mais difícil obter essas conquistas. Muitas são as tentativas de negociação. Trocas de cartas, telefonemas, reuniões menores, seminários, eventos e audiências públicas são as diferentes formas utilizadas pela Educafro para cobrar dos representantes públicos as ações de democratização do acesso ao ensino superior. Tendo em vista essa estratégias de aproximação, a organização encaminha cartas, persuadindo os órgãos públicos, buscando deixar canais de negociação abertos.

Existe uma estrutura dos documentos apresentados pela Educafro às instituições públicas. Com base na análise das cartas encaminhadas às secretarias estaduais, universidades, centros tecnológicos e fundações universitárias, entre os anos de 2002 a 2005, encontramos um padrão argumentativo:

- Normalmente, o documento é encaminhado para o ocupante do posto mais elevado da instituição, por exemplo, o Governador, o secretário de Educação ou de Justiça, o reitor etc; 
- Em geral, o primeiro parágrafo é de apresentação da instituição, a qual é definida do seguinte modo: "A Educafro- Educação e Cidadania para Afrodescendentes e carentes, entidade coordenada por Frades Franciscanos". Nesse mesmo parágrafo, vem a apresentação do número de núcleos que a entidade possui naquele momento.

- A terceira informação diz respeito ao propósito da carta, que pode ser cumprimentos, solicitação, repúdio etc. Por fim, vem o conteúdo relativo à intenção da carta, por exemplo se é de repúdio a Educafro sempre enfatiza a exclusão dos negros e outros "segmentos pobres" do referido processo ao qual se opõem ao procedimento. Agora, se é de felicitação, ela também apresenta argumentos favoráveis à instituição a qual estaria fazendo um bom trabalho em favor dos grupos excluídos, negros e pobres.

- Com freqüência, para embasar a argumentação da exclusão de negros e pobres, a entidade usa como estratégia em seus discursos a presença de informações vindas de órgãos da imprensa ou produções acadêmicas que ganham a grande mídia. A preferência é sempre por jornais de grande peso, como a Folha e o Estadão, para o caso de São Paulo, ou Jornal do Brasil e o Globo para o caso do Rio de Janeiro.

- O terceiro movimento do texto é enfatizar a realidade dos dados, fazendo considerações valorativas. Do tipo "não admitiremos...", "é um absurdo que..."

- Em geral, as cartas da Educafro a órgãos públicos sempre finalizam com tom de ameaça. Por exemplo, ameaça de denunciar ao Ministério Público, à mídia, ao governo do Estado ou a órgãos financiadores.

- Em alguns momentos, a entidade emite opinião acerca de problemas internos da instituição alvo. Por exemplo, apresenta parecer favorável ou contrário à composição de comissões, ou demissão desse ou daquele indivíduo que a organização considera importante para os seus interesses. 


\subsection{Sonho público, experiência privada}

As formas institucionalizadas de pressão social geraram algumas conseqüências políticas. Apesar de a Educafro ter se constituído como uma das protagonistas da lutas por ações afirmativas nas universidades públicas no Brasil, são para as universidades privadas que se dirigem a maior parte dos estudantes egressos dessa rede de cursinho pré-vestibular. Como essa rede aprova muito pouco nos estabelecimentos públicos de terceiro grau, seus estudantes são encaminhados para instituições pagas com quem a organização mantém convênios. Antonio Sérgio Guimarães (2003), um analista atento a esse paradoxo, assinala:

Se é verdade que tais cursinhos têm conseguido ajudar milhares de jovens a ingressar no ensino superior, é também verdade que o seu sucesso é bem maior nas escolas particulares que nas públicas, o que coloca de cara o problema de custeio do curso universitário (p.13).

Desde a formação do primeiro núcleo pré-vestibular, em 1993, e o estabelecimento do primeiro convênio com a PUC/Rio, a relação com as universidades privadas vivenciou um crescimento significativo. No desenvolvimento e na ampliação desses convênios, os estabelecimentos privados de ensino superior disponibilizam suas vagas ociosas para os estudantes da Educafro. Certamente, as bolsas em universidades privadas tornaram-se, pouco a pouco, uma das principais estratégias da organização para inserir estudantes pobres e negros no ensino superior nos últimos anos. Senão, vejamos:

Em São Paulo, chegamos ao mês de abril/2001 com 87 bolsistas na Universidade São Francisco de Assis; 26 bolsistas na PUC-SP; 65 bolsistas na Unisa e 25 bolsistas na Esan; 2 bolsistas na FEI; 16 bolsistas na Faculdade São Luiz; 29 bolsistas na UMC; 22 bolsistas na São Camilo; 144 bolsistas na Faculdades Claretianas; 105 bolsistas na Unisal; 6 bolsistas na Unisantos e 7 bolsistas na Unisanta. No total, até abril de 2001, tínhamos 534 universitários bolsistas!!! Na pública USP, temos 46 alunos entre os matriculados e os que estão cursando como alunos especiais ${ }^{74}$.

Esse quadro passou por uma ligeira modificação com o advento do Programa Universidade para Todos (Prouni) ${ }^{75}$. Isso porque universidades como a PUC ingressaram nesse

\footnotetext{
${ }^{74}$ Documento de divulgação da Educafro, 2001.

${ }^{75}$ O Programa Universidade para Todos (PROUNI) foi criado através da medida provisória $\mathrm{n}^{\circ}$. 213, de 10/09/2004 e institucionalizado posteriormente através da Lei 11.096, de 13/01/2005. Na primeira seleção, cerca de 112 mil
} 
programa federal implementado pelo governo Lula, desfazendo os antigos acordos com organizações civis. Nessa nova configuração, a Educafro manteve vínculos apenas com algumas faculdades e universidades, muitas das quais não passaram pelo crivo do Ministério da Educação para aderir ao Prouni. Ademais, o Programa Universidade para Todos tornou-se uma das opções dos cursistas dessa rede de pré-vestibular, a qual tomou para si a incumbência de divulgar o programa para sua "clientela". A publicidade institucional abaixo não deixa dúvidas da parceria tácita entre a entidade negra, as universidades privadas e o governo federal:

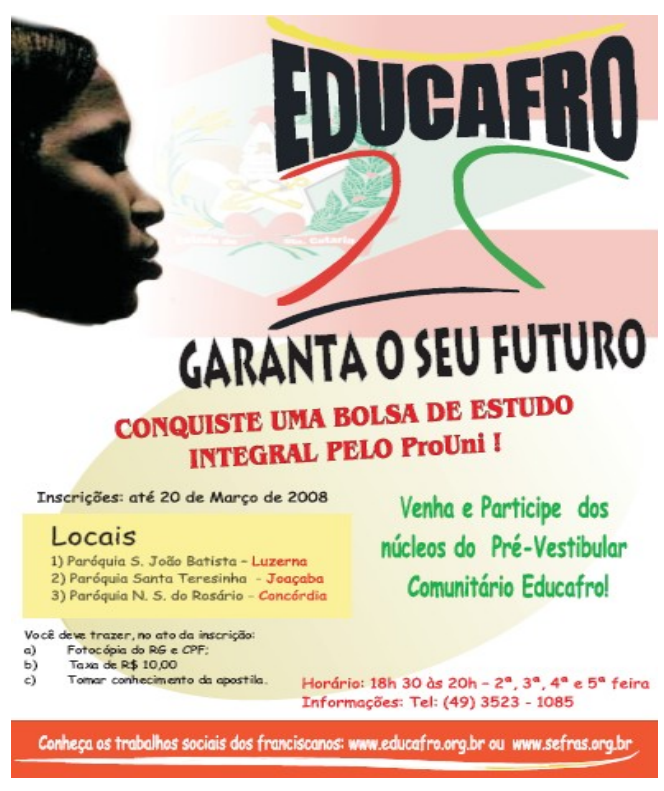

Fonte: Fotografia de cartaz em núcleo da Educafro, 2007

A imagem acima é sociologicamente emblemática. O pôster parece simbolizar as formas concretas com que o ativismo negro e demais movimentos sociais têm vivenciado a democracia brasileira. O slogan "garanta o seu futuro" expressa as novas relações entre as entidades negras e o grupo social que pretendem representar, isto é, um segmento populacional com acesso desigual aos bens educacionais. Longe da proposta de "conscientização racial" que marcou os anos de 1970 e 1980, o que temos aqui é a "oferta" de alternativas para mobilidade ascensional. Um projeto político cujas prerrogativas têm sido parcerias entre sociedade civil e governo.

estudantes foram beneficiados. A meta do projeto era atingir por meio de bolsas integrais ou parciais cerca de 400 mil em 4 anos. 
O Prouni foi apresentado pelo governo Lula como um dos principais programas de democratização do ensino superior. Trata-se de uma das iniciativas da reforma universitária desse governo, a qual conta também com a expansão das universidades federais e a implementação de cotas para alunos da rede pública, negros e indígenas. Os críticos do Prouni desconfiam desse projeto de democratização, uma vez que não possui uma política de permanência eficiente e ampla, o que pode acarretar evasões elevadas e desempenho baixo devido à dificuldade financeira de manutenção no curso. Além do mais, a principal objeção levantada por Catani et al (2006) é que "os cursos superiores ofertados pelas IES privadas e filantrópicas são, em sua maioria, de qualidade questionável e voltados às demandas imediatas do mercado" (p.126).

Em resposta à demanda dos movimentos sociais por ensino superior, o Governo Lula adotou uma política de renúncia fiscal para garantir a concessão de bolsas parciais e integrais em estabelecimentos de ensino superior privado (Carvalho, 2006). O tipo de acordo estabelecido com as IES foi altamente providencial, porque tentava resolver vários problemas de uma vez só, quais sejam: a demanda pelo ensino superior encaminhada por organizações civis como a Educafro; o elevado índice de vagas ociosas em estabelecimentos privados e a necessidade do governo em cumprir suas metas internacionais relativas ao aumento de pessoas com diplomas de graduação. Catanni et tal. explicita esse quadro:

O princípio do Prouni segue essa orientação: promove o acesso à educação superior com baixo custo para o governo, isto é, uma engenharia administrativa que equilibra impacto popular, atendimento às demandas do setor privado e regulagem das contas do Estado, cumprindo a meta do Plano Nacional de Educação (PNE - Lei $n^{\circ} 10.172 / 2001$ ) de aumentar a proporção de jovens de 18 a 24 anos matriculados em curso superior para $30 \%$ até 2010. Pretende, ainda, atender ao aumento da demanda por acesso à educação superior, valendo-se da alta ociosidade do ensino superior privado (35\% das vagas em $2002,42 \%$ em 2003 e 49,5\% em 2004) (2006,127.).

Com efeito, esse programa de inclusão social no ensino superior desenvolvido na gestão do ministro da educação Fernando Haddad, recebeu apoio das organizações civis. A própria Educafro, na figura do Frei David, ocupa no governo uma cadeira na Comissão Nacional de 
Acompanhamento e Controle Social (Conap) do Programa Universidade para Todos, criada no ano de 2007, com objetivo de monitorar o desempenho do programa $^{76}$.

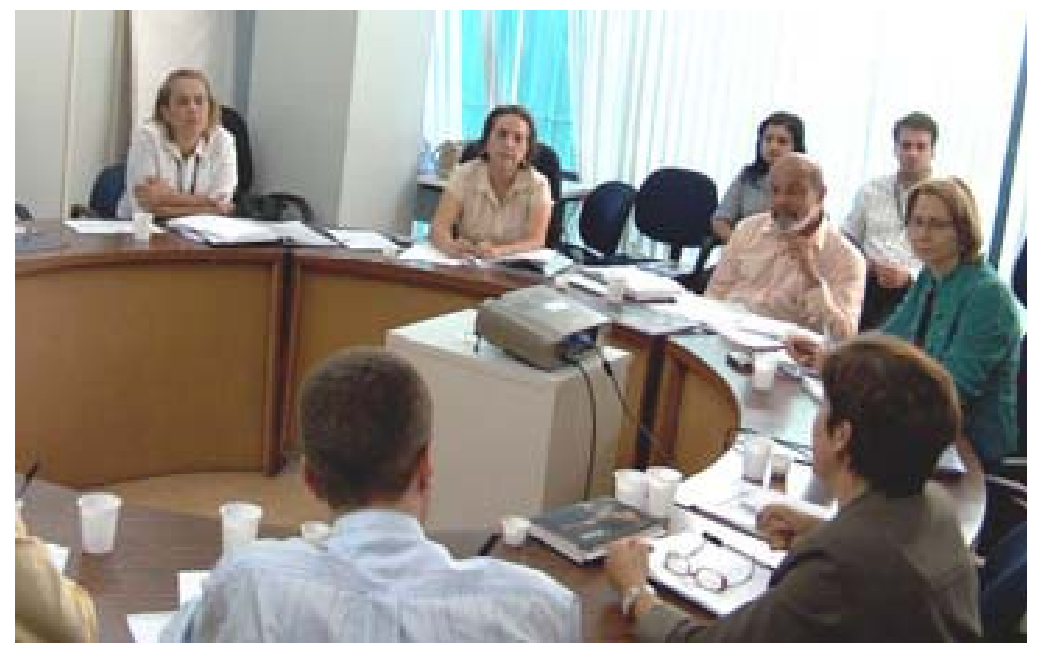

Fonte: Jornal da Educafro, outubro de 2007.

O Prouni é, certamente, o exemplo da aproximação entre o governo e a Educafro, a qual se constitui como uma das principais parceiras do governo nessa política de ensino superior. E isso não está em contradição com a ideologia e experiência desta organização, a qual manteve as universidades privadas como aliadas no projeto de inclusão no ensino superior. No ano de 2007, o jornal da Educafro contabilizava a aprovação de 1.400 alunos ligados a sua rede de prévestibulares. A maior parte deles são de escolas privadas, com as quais a Educafro tem parceria como a Universidade São Francisco, Sumaré, Metodista, UniFai, Hoyler, Unisantos, Unisantana.

Apesar das universidades privadas serem o principal canal de acesso ao ensino superior para jovens egressos da Educafro, as instituições públicas possuem um lugar privilegiado na representação da organização e de seus bolsistas. A estratégia da transferência das universidades privadas para as públicas é um conselho que lideranças e coordenadores de núcleos costumam dar para os jovens não desistirem dos sonhos de ingressar nessas últimas. A eficácia dessa estratégia é pequena quando considerado o montante de bolsistas dessa rede de cursinhos que se

\footnotetext{
${ }^{76}$ Essa comissão é composta por representantes dos alunos das instituições privadas de ensino superior, da União Nacional de Estudantes (UNE); da União Brasileira dos Estudantes Secundaristas (Ubes); Docentes das instituições privadas de ensino superior; dirigentes das instituições privadas de ensino superior; representantes da sociedade civil, onde figura a presença de Frei David. (Jornal da Educafro, Edição Nacional Ano IX, Nº 111 Outubro 2007).
} 
formam em estabelecimentos privados todos os anos. Contudo, os casos de transferência servem de exemplos e emblemas para a organização, recebendo destaque privilegiado.

Um exemplo disso é a fotografia de um estudante negro estampada na primeira página do jornal da Educafro, porque este teria conseguido ingressar no curso de letras da USP. Ele é elogiado por sua persistência e dedicação, pois estudou na rede de cursinhos para negros e carentes, foi professor e coordenador de núcleo, depois ingressou na Universidade São Francisco. Mas, não contente com sua bolsa integral naquela instituição, continuou pleiteando uma vaga na universidade pública até conquistá-la. A reportagem mais do que informar o sucesso do candidato, pretende apresentar o caminho percorrido por ele.

Os estudantes que entram em universidades públicas são celebrados como um modelo, como um caso a ser seguido. No ano de 2007, o jornal noticiava a história de uma aluna que ingressou na universidade federal de Alagoas (UFAL). O título da reportagem, que dispensa comentários, já trazia consigo um modelo para o ingresso na universidade pública: Como chegar à universidade pública? A reposta vinha com a trajetória da bolsista, que estudou dois anos no núcleo da Educafro e depois ingressou no curso de serviço social na Faculdade São Francisco, em que cursou por mais dois anos. Logo depois prestou transferência para a UFAL, onde cursaria Ciências Sociais.

Os exemplos de sucesso apresentados pela Educafro sugerem o grau de dificuldade para o acesso à universidade pública, mas também informa que não é impossível. O caminho para acessá-lo deve seguir uma estratégia racional: ingressar primeiramente numa universidade privada e depois pedir transferência ou ainda continuar prestando os vestibulares nas universidades públicas. A persistência é um valor que é estimulado pela organização.

Note-se bem que os estudantes que ingressam nas universidades públicas quase sempre fazem cursos de baixo prestígio social como letras, ciências sociais, história e pedagogia, só para citar alguns. Para aqueles estudantes que pretendem disputar carreiras com maior valor social, o caminho é quase sempre as universidades privadas.

Assim, a solução mais freqüente que a Educafro pode oferecer é encaminhar seus cursistas para carreiras com mais status social em faculdades que não gozam dessa posição, ou seja, o caminho mais freqüente é ingressar em curso de prestígio em faculdades desprestigiadas. A Educafro funciona como uma rede que potencializa o ingresso de estudantes negros nas 
universidades particulares, com possibilidade de bolsas parciais ou integrais. Isso fica bem nítido nos modelos que a organização destaca para servir como experiência exemplar. Em São Paulo, a Universidade São Francisco destaca-se porque possui um alto contingente de egressos da rede pré-vestibular para negros e carentes. Em maio de 2006, o jornal da Educafro noticiava mais de 1.862 bolsas parciais ou integrais destinados aos seus ex-cursistas nessa universidade, em seus diferentes campi. Nela, os candidatos costumam pleitear vagas integrais no curso de Direito. Não foram raras as vezes em que tais estudantes expressavam em tom de orgulho a satisfação que tinham de fazer o curso de Direito.

Com efeito, os sonhos dos estudantes de ingressar em carreiras prestigiosas não se acabam quando tomam ciência de que o sistema educacional ainda é excludente. Com os sonhos das pessoas, a Educafro precisa se haver em algum momento. Nesse sentido, os arranjos e as estratégias não desfazem as possibilidades dos estudantes. Os sonhos não são desfeitos, apenas refeitos para adequarem-se ao leque de possibilidades que se apresentam na atual conjuntura político-educacional.

\subsection{Entre os sonhos e as estratégias: um projeto social internacionalizado}

Uma possibilidade aberta pelo processo de institucionalização do movimento negro é a globalização das formas de intervenção social. Desde 2001, a Escola Latina Americana de Medicina (ELAM), uma instituição cubana, oferece anualmente, através da Embaixada de Cuba, bolsas de estudos no curso de medicina para partidos políticos, instituições e movimentos populares, como o Partido dos Trabalhadores, a Educafro, o Movimento dos Sem Terra, dentre outros. Em que pese a intencionalidade do Governo de Fidel Castro, no âmbito das relações internacionais e suas articulações com o governo e, sobretudo, com a sociedade civil brasileira, para o escopo de nossa análise cabe realçar os efeitos desse convênio com a Educafro e seus desdobramentos na relação dessa organização com seus associados.

Para entender esses efeitos, basta dizer que o curso de medicina figura entre as carreiras de maior prestígio no Brasil, por isso seu acesso é particularmente competitivo, exigindo dos candidatos um certo perfil sócio-econômico e educacional. Ciente do grau de dificuldade de acesso aos cursos de prestígio, tanto a organização quanto seus estudantes precisam lidar com essa realidade em suas estratégias e avaliações, uma vez que os cursistas da Educafro não 
costumam apresentar o perfil sócio-econômico exigido para os cursos de alta competitividade. Os próprios estudantes sabem dessa realidade. Alguns chegam até a concorrer a tais cursos, mas não são bem sucedidos nas investidas. Por outro lado, a Educafro compreende que seu projeto político educacional não possui recursos suficientes para alocar estudantes pobres em cursos de prestígio. Nesse sentido, além dos convênios com as universidades particulares, o acordo estabelecido com a ELAM permite a organização abarcar certas expectativas dos seus cursistas.

Assim, a Educafro envia uma média de 8 a 10 estudantes para Cuba anualmente. Esse número alarga-se a partir de 2006, com a expansão da ELAM para a Venezuela. A Escola Latino Americana de Medicina estabeleceu-se nas terras de Hugo Chaves naquele ano e manteve o acordo com os demais países latino-americanos, incluindo o Brasil. O fato é que a Educafro consegue enviar anualmente cerca de 20 estudantes para cursar medicina em Venezuela e em Cuba. O número é aparentemente pequeno, contudo, o apelo social dessas vagas é realmente significativo para os cursistas, sobretudo porque o Estado cubano possui uma política de permanência para estudantes estrangeiros, incluindo moradia, materiais do curso e alimentação. Caberia ao estudante custear apenas sua passagem e gastos adicionais.

Todos os anos cerca de 100 estudantes oriundos de diferentes núcleos de base da Educafro competem por uma vaga na ELAM. Para isso, precisam manter um vínculo institucional com a Educafro, o que inclui todas as obrigações ligadas às "ações de cidadania", exigidas pela organização. Tais obrigações incluem desde assiduidade nas reuniões dos núcleos de base até as reuniões gerais na sede da Educafro, bem como participação em atividades de militância como protestos, eventos e demais ações públicas que a organização promove. Além das obrigações com a organização, os candidatos devem preparar a documentação pessoal necessária para a viagem e para seu estabelecimento no país. O desempenho dos estudantes nos simulados e nos vestibulares nacionais representa a terceira cobrança da organização aos candidatos, o que pode ser atestado pelos coordenadores e professores do núcleo em que está alocado cada candidato.

Esse processo é muito marcante para a trajetória dos estudantes, porque mexe com os seus sonhos, ambições, expectativas e interesses. Trata-se verdadeiramente de um momento de inflexão na vida daqueles que conseguem partir. Para os que ficam, mantém-se a esperança de que podem conseguir no ano seguinte. Em ambos os casos, prevalece o sentimento de que o país 
em que vivem não pode abrigar seus sonhos e projetos individuais. Vejamos como a organização lida com a representação social de seus cursistas, em publicidade do curso de medicina:

\begin{abstract}
Você tem algum parente formado em Medicina? Seu pai, sua mãe ou seu irmão tem, em seu círculo próximo de amigos, um profissional em Medicina? Temos certeza que, na maioria dos casos, a resposta será não. E sabemos por quê. A Medicina é um dos campos do conhecimento mais restrito àqueles de condição financeira privilegiada. No entanto, ser médico/a é sonho de milhares de negros/as e pobres, além de ser uma necessidade da nação brasileira. Portanto temos a obrigação de divulgar em nossos núcleos e comunidade a oportunidade que a Educafro oferece, através de convênios com a Embaixada Cubana no Brasil e Embaixada Venezuelana, através de Bolsas de Estudo Integrais nesses países. Hoje cerca de 100 estudantes negros e pobres da Educafro estudam com bolsa $100 \%$ em Cuba e na Venezuela, a maioria deles o curso de Medicina $^{77}$.
\end{abstract}

A trajetória de um dos estudantes de medicina em Cuba pode ilustrar o quanto essa proposta vem de encontro às expectativas de jovens que "sempre sonharam" em ser médicos. A experiência de Cleber mostra simultaneamente as ambições individuais, o envolvimento coletivo e o modo pelo qual a organização constrói suas testemunhas de sucesso ${ }^{78}$.

O estudante paulista do último ano do curso de medicina em Cuba sempre sonhou em ser médico: "desde criança quis estudar medicina". Cleber é o único filho do sexo masculino de uma família de quatro meninas. Nenhuma delas cursou o ensino superior, nem seus pais o fizeram. Um jovem morador da região metropolitana da cidade de São Paulo, ele contava apenas com 19 anos quando ingressou no cursinho da Educafro em sua cidade, Poá. A posição desse estudante é particularmente interessante, porque possui informações gerais acerca do perfil dos estudantes brasileiros que vivem em Cuba. Ademais, Cleber também já se tornou um dos garotos propaganda da Educafro na sua luta pelo acesso ao ensino superior no Brasil.

Quando consegue recursos para voltar ao Brasil no período de férias escolares, Cleber é recrutado pela Educafro para "semear esperanças" entre os estudantes dos núcleos de base da organização. "O bolsista da Educafro em Cuba", como é chamado Cleber e todos os outros que tenham ingressado na ELAM via Educafro, apresenta-se no núcleo como "testemunha viva" de que é possível lutar e conquistar sonhos aparentemente impossíveis. Os discurso dele é marcado pela gratidão à Educafro, pela revolta contra o poder público que não oferece oportunidades para

\footnotetext{
${ }^{77}$ Jornal da Educafro, fev. ,2008

${ }^{78} \mathrm{Na}$ época que concedeu a entrevista (agosto de 2007), Cleber ingressaria no último semestre do curso de medicina em Cuba e passava pelo Brasil para um estágio temporário na Universidade de Campinas (UNICAMP).
} 
jovens com seu perfil disputar carreiras de prestígio. Mas a dimensão mais emocionante de seu discurso é a alegria de poder estudar em um curso que sempre sonhou.

A Educafro fica em seu discurso como uma grande organização engajada na luta do negro em favor dos mais pobres. A fala de Cleber e dos demais estudantes que tenham passado por essa experiência é um testemunho, e como tal atesta a verdade e conforta os corações dos demais estudantes. Mensagens como a de Cleber são revitalizadoras para a platéia que o escuta. São discursos que para além das emoções que carregam, mobilizam sentimentos morais nos indivíduos. Os valores morais são incitados quando os estudantes/candidatos são convocados a terem coragem para perseguir seus sonhos, sem se acovardar diante da realidade, mesmo sabendo que esta é "excludente para os negros e pobres". A persistência, a coragem, a disciplina e a solidariedade são valores morais acionados nas palestras e nos discursos dos jovens vencedores. Escusado dizer que tais discursos são estimulados e apreciados pela organização.

O peso do testemunho de Cleber (e de outros estudantes como ele) tem maior eficácia, não porque apresentam um caminho eficiente para o sucesso, antes, o enunciador do testemunho assemelha-se à platéia. Esta se comove e se envolve não somente pelas palavras proferidas pela boca de um vencedor: o que convence aqueles estudantes de que o testemunho é verdadeiro é justamente a presença de um homem que se parece com eles. Eles são semelhantes, viveram experiências próximas. Seus gestos são parecidos, assim como suas roupas, a maneira de elaborar as frases e as gírias que usam no discurso. $\mathrm{O}$ orador e a platéia não tinham distinção de classe, de cor, religião, de origem, de nacionalidade. Eram ambos originários de um berço comum. E o que os uniam não era apenas a identidade de posição social ou de filiação racial, o que os assemelha é a disposição para modificar o destino social a que estão submetidos.

Oriundo de escola pública, filho mais velho de mãe empregada doméstica e pai ferroviário, Cleber é um jovem preto, que assume uma identidade negra e prefere ser chamado assim. Ele tomou conhecimento do cursinho pela Folha de São Paulo, que noticiou o convênio da Educafro com a ELAM. Quando soube da possibilidade de cursar medicina em Cuba, ingressou na rede pré-vestibular para negros e carentes. Depois de um ano de processo seletivo, atendeu a todos os requisitos da organização. Mas antes disso prestou os vestibulares paulistas para cursar medicina, mas não obteve êxito. 
Cleber, que já possui uma larga experiência em Cuba, está feliz por ter conseguido viver por lá, apesar das dificuldades. Segundo ele, os estudantes que seguem para aquele país são realmente de baixa renda. A única crítica dele dirigiu-se contra os alunos brancos que ingressam lá, muito embora reconheça que eles possuem uma condição social e econômica semelhante a sua. Cleber identifica uma certa distorção na proposta quando a Educafro seleciona e encaminha mais brancos que negros.

O discurso dele parece coincidir com o tipo de ativismo político que vem desenvolvendo em Cuba. Hoje é um dos coordenadores da União de Afro-descendentes do Brasil, a UADA, que tem como missão integrar os jovens negros brasileiros que chegam a Cuba. $\mathrm{O}$ curioso da UADA é o fato de tratar-se de uma associação que tem como critério a identidade racial, independente da filiação a movimentos ou a organizações. Assim, a UADA, que conta com cerca de 25 associados, costuma desenvolver projetos como a Semana da Consciência Negra em Cuba. Além da UADA, Cleber integra a coordenação da Associação Brasileira de Estudantes de Medicina em Cuba, que é um movimento movido pelo interesse de regresso e estabelecimento no mercado brasileiro. O principal objetivo dessa organização é promover a revalidação do diploma de medicina cubano no Brasil, isso porque seus diplomas não são reconhecidos pela sociedade brasileira de medicina.

Através desse ativismo, Cleber e seus conterrâneos traduzem certas experiências do Brasil para o país de Castro. O exemplo mais marcante é a semana de Consciência Negra, que desenvolveram juntamente com estudantes de segmentos como PC do B, PT e MST. Começaram inicialmente com um dia da consciência negra e nos anos subseqüentes conseguiram aumentar os dias comemorativos e desenvolver atividades nas diferentes unidades da ELAM, localizadas em diversas províncias cubanas. O projeto dos brasileiros envolve estudantes de diferentes países latino-americanos, que são convidados para falar da história e cultura dos negros em seus países. Ao despender esforços para a construção dessa data comemorativa, os jovens estudantes brasileiros não só reavivam sua identidade racial, como reafirmam a sua origem nacional, difundindo e internacionalizando um ideário construído pelo movimento negro brasileiro. 


\subsection{Algumas Considerações}

A internacionalização do movimento negro brasileiro é apenas uma das faces do ativismo contemporâneo. Articulações internacionais tem sido cada vez mais as marcas das organizações negras, especialmente no que toca ao financiamento (Telles, 2003), à inserção nas conferências internacionais (Santos, 2005); ou às redes de ativismo via Internet e coletivos políticos (Sebastião, 2007). No caso da Educafro, esse tipo de internacionalização tem ocorrido, especialmente, via o convênio supracitado. Além da expansão do movimento para fora das fronteiras do país, as evidências levantadas nesse capítulo demonstram que a entidade passou por um processo de institucionalização crescente nos últimos anos, informando, em certa medida, o perfil da militância negra que "influencia" a política institucional no Brasil contemporâneo.

O novo perfil de militância exige profissionalização das organizações e dos ativistas. A Educafro, apesar de ser uma organização ligada à Igreja Católica, precisou criar uma equipe técnica permanente para atender as demandas da entidade. Assim, ela recruta pessoas com formação em direito, em comunicação ou jornalismo, em educação (licenciatura e pedagogia), as quais compõem o quadro de funcionários da instituição. Essa equipe é contratada para manter o cotidiano da organização e suas demandas, como a preparação de ações judiciais, de release para a mídia, de informações para o site, de redações para o jornal da entidade. Além disso, ela possui um corpo administrativo que deve ter bons conhecimentos de informática e secretariado para o controle dos núcleos, estudantes de cursinhos e seus bolsistas. Esses trabalhos são realizados por funcionários da organização, os quais são pagos com os recursos da Província Franciscana.

Além dos funcionários, a organização convoca assessores para auxiliá-la em investidas que fogem as suas atividades cotidianas. Em geral, são advogados, professores, publicitários, estudantes universitários de diferentes áreas que prestam serviços pontuais e não remunerados. Essas pessoas podem ser de outras ONGs negras ou não e podem também ser ex-bolsistas da organização, bem como profissionais liberais simpatizantes com a "causa da igualdade racial". Estes últimos são recrutados a partir das redes informais construídas ao longo dos anos de ativismo da entidade.

Uma outra marca do perfil da militância contemporânea parece ser a especialização de certas demandas sociais. O movimento negro brasileiro atua em grandes áreas: como a educação, 
saúde, trabalho e advocacia de Direitos Humanos. Desses campos de atuação, a Educafro focaliza à área de educação, especializando-se no segmento do ensino superior, por isso a organização dedica-se, quase que exclusivamente, à gestão das demandas de seus cursistas e à luta por políticas públicas nas universidades.

Desse modo, a entidade se organiza de modo a prestar serviços a um público alvo, que são estudantes pobres e negros desejosos de obter um diploma universitário. Estes se inserem na organização através dos núcleos, aspirando ingressar numa instituição de Ensino Superior, as quais, acreditam, lhes podem oferecer melhores chances na vida. Durante sua caminhada, alguns destes jovens tornam-se ativistas engajados na organização de onde ingressaram. Com estes militantes, a Educafro conseguiu manter-se firme na última década. Assim, a longevidade da instituição e a persistência de seu projeto parecem estar relacionadas à capacidade de administrar as exigências necessárias ao ativismo atual. 


\section{OS PROTESTOS NEGROS}

\subsection{Introdução}

A palavra "protesto" na literatura acadêmica assumiu sempre um amplo sentido de reivindicação, como na produção sociológica dos anos 1950, em que parece se referir aos feitos e discursos dos movimentos negros contra o preconceito de cor. Desde então, esse termo permaneceu na linguagem dos pesquisadores, de modo que George Andrews (1991) consolidou essa idéia ao chamar de "protesto negro" toda a sorte de mobilização política anti-racista produzida por este grupo racial.

Embora guarde esse significado caro aos estudos sobre movimento negro, o termo "protesto" será utilizado analiticamente para designar um dos repertórios de ação (Tilly, 2005) desse movimento social, ou seja, um formato específico de atividade coletiva, tal como as marchas, passeatas, paradas, ocupações e desfiles pelas ruas ou atos públicos. Isso porque nos interessa separar o protesto das práticas coletivas diárias no interior de organizações e espaços reservados. O protesto assume franco objetivo de ser um evento público, cuja função é chamar para si a atenção da sociedade e autoridades, preferencialmente através das câmeras e holofotes ou notícias impressas através das quais ganham visibilidade. Assim, os protestos não fazem parte da vida diária das pessoas, nem mesmo na vida dos ativistas. Trata-se, antes, de uma forma de ação que tem um caráter eventual e, por isso, marca uma ruptura com o cotidiano.

Essa forma de atuação pública será objeto de exame no presente momento; isso porque o protesto no movimento negro passou por profundas modificações ao longo das últimas décadas. Tais modificações são menos de forma que de significado. Os protestos de rua continuam presentes no movimento, contudo o sentido social que se quer transmitir na atualidade parece diferir daquele que marcou o retorno do movimento na cena pública brasileira nos anos 70 e 80 . De lá para cá, cada vez mais, os atos públicos do movimento negro têm tomado uma forma expressiva, litúrgica e pedagógica perante a sociedade e o Estado, uma vez que as formas de contestação e de reivindicação puderam assumir outros espaços: nem tanto as ruas e, sim, as mesas de negociação, as reuniões com autoridades políticas e econômicas, as plataformas 
partidárias, as lutas judiciais e os compromissos com órgãos internacionais e com o Estado brasileiro. Isso não torna as marchas, os atos e as ocupações objetos de menor relevância para o estudo dos movimentos sociais. Muito ao contrário, no protesto encena-se o enredo do conflito social, em sua forma simbólica e coletivamente organizada. Assim, os atos públicos são fontes privilegiadas para apreender o movimento como um todo: as alianças, as mobilizações, as bandeiras, os oponentes, as divergências, os símbolos, as identidades coletivas e os discursos.

Realizado nas escadarias do Teatro Municipal de São Paulo em 1978, o ato do Movimento Negro Unificado Contra a Discriminação (MNUCDR) ${ }^{79}$ acenou para a forma de protesto social que o movimento negro no Brasil tomaria para si, porque os espaços públicos abertos como as ruas e avenidas passam a ser cada vez mais palco de manifestações negras. Se as décadas de 70 e 80 viram florescer o protesto reivindicativo, a década de 90 viveu profundas transformações, nas quais o protesto ganhou aspectos mais expressivos do que reivindicativos. $\mathrm{O}$ exemplo paradigmático desse fenômeno é a Marcha Noturna pela Democracia Racial.

Essa mudança pode estar relacionada à estrutura de oportunidade política (McAdam 1982, Tarrow, 1998 e Tilly, 2005), que quer dizer abertura do Estado, implicando maior acesso às estruturas estatais, bem como abertura da opinião pública que, ao discutir as demandas mais polêmicas desse movimento social, acaba que por colocá-lo em evidência, o que também foi notado por Cott (2000) para os casos da Colômbia e Bolívia.

A maneira de mobilizar recursos para o protesto não difere muito do que dizem os teóricos dos movimentos sociais (McCarthy e Zald, 1977). Sem estrutura para grandes mobilizações de massa em seus atos públicos, o movimento precisa construir amplas alianças com suas entidades de base e coletivos organizados para atingir um número razoável de pessoas em seu evento público. Além disso, a mobilização negra brasileira conta com outro obstáculo, o qual foi enfaticamente problematizado pela literatura acadêmica e recebeu de Hanchard (2001[1994]) sua melhor formulação, qual seja: a hegemonia da democracia racial na cultura brasileira atua como elemento desmobilizador das massas ${ }^{80}$. Isso levantaria um tipo de problema

\footnotetext{
${ }^{79}$ O Movimento Negro contra a Discriminação Racial mudou seu nome para Movimento Negro Unificado.

${ }^{80}$ Essa foi a principal hipótese aventada por Hasenbalg (1979) e foi levada a cabo por Hanchard, que demonstrou os dilemas da mobilização negra no Brasil, devido ao mito da democracia racial, seja como ideologia difusa na sociedade, seja como política de Estado.
} 
para os ativistas negros que não se restringe ao campo econômico e político, mas também ao cultural.

Porém, desde a pesquisa de campo realizada por Hanchard, nos anos de 1988 e 1989, até hoje houve muitas mudanças na mobilização negra brasileira e os referidos problemas ainda persistem, porém num quadro mais complexo. Isso porque na medida em que o movimento cresceu e ganhou mais legitimidade, outras organizações civis e estatais passam a ser fontes de recursos para a mobilização. Mais do que antes, hoje a organização dos protestos conta com auxílio na estruturação de suas investidas públicas, em que se verificam os apoios dos partidos, organizações externas, ordens religiosas e Estado. Com o fito de mostrar esse quadro e suas mudanças ao longo do tempo, serão objeto de análise neste capítulo o Ato Público de Fundação do MNCD (1978), as marchas do Centenário da Abolição (1988), a Marcha do Tricentenário de Zumbi (1995) e a Marcha Noturna pela Democracia Racial (1997-2008), através dos quais as transformações na encenação pública da luta social podem ser vistas de uma perspectiva processual.

Na luta social, o movimento negro tenta imprimir um novo significado à idéia de Brasil e a história do país torna-se objeto de litígio. No tempo presente, luta-se pela narrativa do passado, recontada para legitimar as pautas de reivindicações sociais postas na cena pública. No protesto, busca-se, ainda, dar vivacidade à memória em retalhos, costurada pelos ativistas e carregada de emoções, sentimentos e significados para o coletivo político e, em especial, para cada sujeito envolvido na mobilização.

\subsection{O Ato de re-fundação do movimento negro}

O primeiro marco dos protestos reivindicativos do movimento negro contemporâneo foi o ato público promovido nas escadarias do Teatro Municipal de São Paulo, no dia 07 de Junho de 1978, quando um conjunto de organizações negras de diferentes partes do país decidiu aderir ao movimento nacional que visava combater a "discriminação racial” e a opressão da política, em favor de "uma verdadeira democracia racial"

\footnotetext{
${ }^{81}$ Em carta aberta do Movimento Negro Unificado, em 07/06/78.
} 
objetivo de "ampliação do movimento", seja pela adesão de outras organizações negras, seja pelo apoio dos "setores democráticos da sociedade".

O relato do então funcionário do Metrô e estudante de economia da USP, Milton Barbosa, é bastante esclarecedor. Vindo da militância na liga clandestina da Causa Operária e do centro de cultura Negra, o CECAN, um dos embriões do $\mathrm{MNU}^{82}$, Milton oferece informações acerca do estado de espírito das lideranças paulistas que encabeçavam o ato: "no dia, nos encontramos na galeria Nova Barão e saímos meio que abraçados uns com os outros, morrendo de medo". ${ }^{83}$

Amauri Mendes, já formado na UFRJ em Educação Física e fundador da Sociedade de Intercâmbio Brasil-Africa (SINBA) - uma das organizações que assinou a carta de fundação do MNU - veio do Rio de Janeiro para o evento. A fala dele reforça a insegurança e o medo que atingiam os ativistas. Todos pareciam muito receosos, já que a possibilidade de repressão poderia ocorrer. Não era para menos: tratava-se do primeiro evento de aparição pública do movimento negro unificado em nível nacional:

\footnotetext{
Havia muita polícia e a polícia em São Paulo era aqueles caras enormes, todos brancos. Eu sempre lembro assim: um pescoço daquele tamanho. A gente cria as coisas. Os caras do lado e a gente na calçada do Mappin (...). Para começar tinha que atravessar do Mappin para a escadaria do teatro. E quem vai dar o primeiro passo? Isso era uma interrogação porque a polícia estava ali para reprimir (...) Ninguém sabe quem foi primeiro. Num dado momento foi e, quando foi, a polícia não reprimiu. E foi importante aquele momento. ${ }^{84}$
}

O evento foi flagrado pelos olhares atentos da mídia paulista e também não escapou ao interesse do Departamento da Ordem Política e Social (DOPS), que espionava o movimento negro e seus ativistas ao longo da década de 1970 (Kössling, 2007). O DOPS manteve em seus registros a prova fotográfica que recolhera de um jornal, esquecendo-se, contudo, de dizer a fonte da qual retirou a imagem.

\footnotetext{
${ }^{82}$ Para mais detalhes da trajetória do CECAN e sua relação com MNU, ver Joana Silva,1994.

${ }^{83}$ Depoimento Milton Barbosa concedido a Alberti e Pereira, 2007, p. 151

${ }^{84}$ Depoimento concedido a Alberti e Pereira, 2007, p. 153
} 


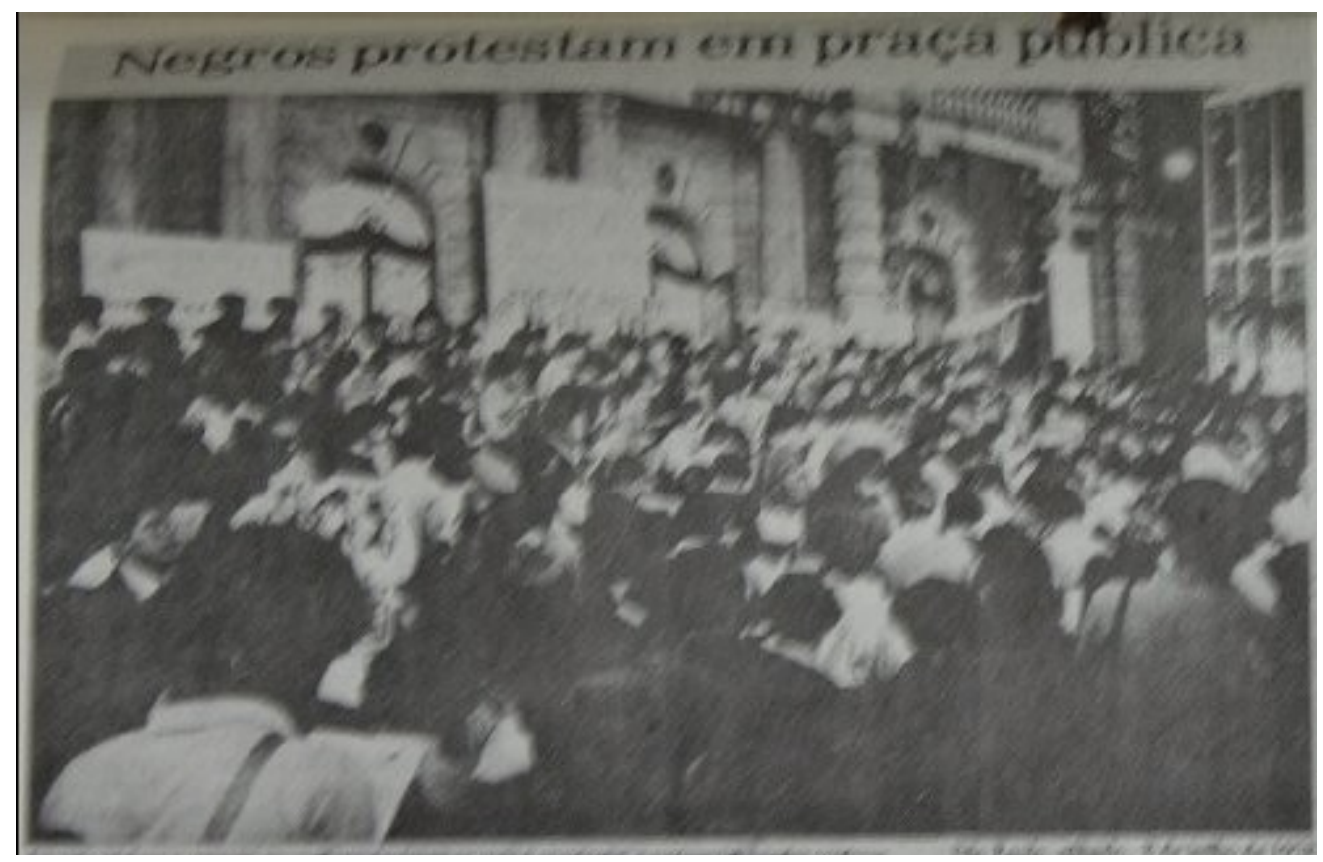

Foto extraída de jornal não identificado do arquivo do DEOPS/SP/ DAESP, Apud KÖSSLING (2007)

Do ponto de vista do movimento, a intenção dos ativistas não deixava dúvidas: a manifestação era um novo desafio para a mobilização negra que até então, por conta da repressão militar, estava restrita a encontros, reuniões e seminários. Eles sabiam que o ato constituía um novo marco para o seu repertório de ação: as ruas passavam a ser espaços de denúncia:

Hoje estamos na rua numa campanha de denúncia! Campanha contra a discriminação racial, contra a opressão policial, contra o desemprego, o subemprego e a marginalização. Estamos nas ruas para denunciar as péssimas condições de vida da comunidade negra. Hoje é um dia histórico. Um novo dia começa a surgir para o negro! Estamos saindo das salas de reuniões, das salas de conferências e estamos indo para as ruas. Um novo passo foi dado na luta contra o racismo. ${ }^{85}$ (Grifos meus).

A grande liderança esperada era Abdias do Nascimento, que esteve lá ao lado de Lélia Gonzalez, uma das ativistas do movimento que emocionava os demais integrantes devido ao seu poder de oratória. Muitos anos depois, Nascimento, ao rememorar o mesmo evento, enfatizou o quão marcante foi o evento para o coletivo e, para ele, como agente e testemunha ocular do ato. Em sua opinião, a manifestação era a expressão do desenvolvimento do movimento negro e a consolidação de uma nova militância, gestada durante os anos 70:

\footnotetext{
${ }^{85}$ Carta aberta do MNU, em 07 de junho de 1978.
} 
$\mathrm{O}$ ato público nas escadarias do Teatro Municipal de São Paulo foi um momento inesquecível ainda em pleno regime militar. Na Bahia, no Rio de Janeiro, em Belo Horizonte e em São Paulo, participamos de reuniões de consolidação do movimento(...). Foi ao mesmo tempo um início e um momento culminante, pois a fundação do MNU deu expressão a toda uma militância negra, que vinha se firmando através da década de 1970 (Nascimento, 2000, p.219).

Certamente, o ato de 1978 teve o caráter explicitamente contestatório e reivindicativo, sobretudo porque naquele momento não havia ainda nenhum tipo de organização pública que pudesse servir de canal para demandas do movimento, aliás o assunto da discriminação racial era um tema que atentava contra a ordem de segurança nacional (Gonzalez, 1983). A reivindicação, numa perspectiva estrutural, exigia o reconhecimento da existência de racismo e desigualdade social entre as raças, uma vez que o discurso oficial da ditadura militar baseava-se no mito da democracia racial, como afirma Guimarães (1999):

Nos anos de ditadura militar, entre 1968 e 1978, a 'democracia racial' passou a ser um dogma, uma espécie de ideologia do Estado brasileiro. Ora, a redução do anti-racismo ao anti-racialismo, e sua utilização para negar os fatos de discriminação e as desigualdades raciais, crescentes no país, acabaram por formar uma ideologia racista, ou seja, uma justificativa da ordem discriminatória e das desigualdades raciais realmente existentes ( p. 62).

Numa perspectiva contextual, os acontecimentos imediatamente anteriores à formação do MNU foram tomados pelos ativistas como exemplos aberrantes da discriminação no país. Tratava-se do assassinato do primo de um dos integrantes do movimento e o caso de discriminação contra atletas negros barrados na porta de um clube, que foram tomados como casos "representativos" da violência contra negros durante o regime de ditadura. Esses eventos contextuais, no calor das emoções, foram decisivos para impulsionar a atividade pública nas escadarias do Teatro Municipal.

Assim, esse ato de fundação - mesmo depois que o MNU deixou de ser a sigla guardachuva das reivindicações do movimento negro - , tornou-se um ponto referencial na história desde movimento social, porque marca a entrada de uma nova campanha política de cunho antiracista com projeção nacional (Hanchard, 2001; Maués, 1998; Guimarães, 1999). Sueli Carneiro, hoje uma das maiores lideranças do movimento e naquela época apenas uma jovem ativista, 
considera que a manifestação foi o "fato político mais importante para o movimento negro contemporâneo (...), porque tudo o que ocorre depois se referencia a esse ato inaugural de refundação". ${ }^{86}$

\subsection{As marchas do centenário da abolição}

Depois do protesto das escadarias, em 1978, apenas o centenário da abolição em 1988 conseguiu entrar para a história do movimento negro como o segundo marco nacional do protesto anti-racista. Ao contrário da fundação do MNU, a onda de protestos que questionou a data comemorativa de 13 de maio possuiu maior alcance e projeção pública, afinal de contas já havia uma marcha pela abertura democrática expressa na campanha pela reforma constitucional. Não era para menos, trata-se de uma oportunidade política francamente aberta para a inserção do movimento negro na cena pública.

Dez anos depois do ato no Teatro Municipal, tudo era um pouco diferente. Não só o movimento tinha se modificado, como também a conjuntura nacional estava em mudança: os ventos democráticos assobiavam mais na sociedade civil e nas estruturas estatais. De um lado, havia um processo franco de expansão e diversificação do movimento negro, revelado, sobretudo, na formação de novas organizações e na constituição dos coletivos de mulheres negras, que ampliou o repertório discursivo do movimento, com a inclusão das questões de gênero e temáticas correlatas. De outro lado, o movimento conseguiu alguns espaços institucionais, como foi notado por Hanchard: "o protesto afro-brasileiro do fim dos anos setenta e início dos anos oitenta levara à criação de assessorias e comissões no Rio de Janeiro e São Paulo" (2001, p.169). Assim, o protesto do 13 de maio contava com outras condições objetivas de realização. Era, sem dúvida alguma, um movimento com mais aportes institucionais e mais experiência de ativismo.

Muitos analistas não deixaram de perceber os impactos do contexto do centenário para a vida política nacional, sobretudo no que se refere à intervenção contundente do movimento negro. Lilia Schwarcz (1990) percorreu diversos eventos em São Paulo por ocasião do 13 de maio. Muitas dessas atividades públicas tinham caráter oficial ou eram realizadas em espaços

\footnotetext{
${ }^{86}$ Ver depoimento de Sueli Carneiro concedido a Alberti e Pereira, 2007.
} 
institucionais como universidades, bibliotecas e museus. Em sua narrativa, percebe-se que houve uma mobilização grande por parte do Estado e instituições públicas no sentido de promover reflexões acerca do centenário. Mas o que a autora não sabia à época era que parte de tais eventos vinha das formulações de ativistas negros no interior de órgãos estatais, como o Conselho da Condição Feminina e o Conselho da Comunidade Negra ${ }^{87}$.

Segundo Schwarcz, muitas também foram as interpretações dos atores envolvidos nesses eventos. Assim, a comemoração da abolição teria sido uma espécie de palco em que se encenavam várias narrativas que disputavam um significado legítimo para o centenário. Em pólos opostos, encontravam-se as narrativas do movimento negro e a do Estado. Enquanto a primeira apregoava a falsa abolição; a segunda narrativa queria tornar o 13 de maio uma grande data comemorativa; no entremeio dos eventos, muitas outras interpretações eram construídas. No final de uma das passeatas de São Paulo, ouve-se uma palavra de ordem transcrita por Lilia Schwarcz: "o protesto venceu a comemoração". Esta foi a interpretação do movimento negro paulista.

Muitos outros autores flagraram os protestos negros do centenário através das lentes dos repórteres dos jornais brasileiros. Segundo José Murilo de Carvalho, no Rio de Janeiro, a "Marcha dos negros contra a farsa da Abolição" ocorreu no dia 11 de maio de 1988, na Avenida Presidente Vargas, em frente ao "Panteão de Caxias". Esse protesto foi reprimido pelo comando militar, que mobilizou 600 soldados. Segundo Carvalho, a principal reivindicação dos negros dizia respeito às alterações das condições de vida da população afro-descendente, por conta disso não se justificava a investida militar. Em suas palavras: "mesmo admitindo que houvesse da parte dos manifestantes a intenção de protestar frente ao Panteão, a reação militar, nos termos que se deu não se justificava" (2005, p.156.).

Uma versão vinda do interior do movimento é contada por Ivanir do Santos, da coordenação da marcha carioca, que participou da negociação com o comando do Exército nos momentos mais tensos do conflito. Segundo ele, "ninguém queria esculhambar o Caxias", mas, “Caxias não era um herói para a comunidade negra. É um herói do exército". No decorrer da marcha, segundo Ivanir, a interpretação do Exército era de que os ativistas iriam danificar o busto de Caxias, por conta disso, reprimiu a caminhada dos manifestantes. Com isso, "aí é que o negro

\footnotetext{
${ }^{87}$ Ver depoimento de Edna Roland e Sueli Carneiro concedidos a Alberti e Pereira, 2007.
} 
ia esculhambar o Caxias mesmo!", dado que "a reação do exército tinha provocado em todos nós uma ira" $" 88$.

No caso do Rio de Janeiro, tratava-se de uma marcha em que o "movimento negro estava sozinho", segundo o próprio Ivanir, “os partidos de esquerda não estavam envolvidos”. Mas, com o impacto da marcha frente à opinião pública, causada pela repressão policial,

eles [os partidos de esquerda] correram depois que viram a repercussão que deu, porque, com o Exército, que, para não deixar passar, botou baioneta, é óbvio que a imprensa toda acabou chamando a atenção, e nos deu o que nós queríamos na verdade: mostrar a farsa da abolição $0^{89}$.

Jacob Gorender também fez uma "cobertura" das marchas negras, usando para isso as lentes dos jornais. Segundo ele, "desde passeatas de rua a congressos acadêmicos, os eventos relacionados com a data se salientaram pela tônica da negação: não houve abolição. Em vez de festejo, repúdio" (1991, p.5). Para o historiador, ao repudiar os eventos comemorativos do 13 de maio, as mobilizações negras estavam fazendo "um julgamento de um fato histórico", qual seja, a Lei Áurea, assinada em "pena de ouro" pela princesa Isabel.

Gorender assinala que as discussões acerca do centenário já eram emocionantes desde o ano anterior, quando os ativistas negros agitaram a opinião pública com panfletos e debates críticos ao centenário da abolição. O Rio de Janeiro assistiu a "Marcha contra a falsa Abolição", e o exército reprimiu a caminhada, levando preso alguns manifestantes (1991, p. 91). Gorender também narra vários acontecimentos em diferentes partes do país, São Paulo, Recife, Salvador. Em todos os casos, algumas atitudes e símbolos se repetiam, a morte simbólica da princesa Isabel, seja porque queimavam uma boneca, seja porque falam no enterro da senhora imperial: ambos simbolizando a morte de uma heroína nacional. Tendo em vista a consulta em diferentes jornais, o historiador afirma: "as comemorações ficaram apagadas e depreciadas pelos protestos dos movimentos negros na rua" (Idem).

\footnotetext{
${ }^{88}$ Ver depoimento de Ivanir Santos foi concedido a Alberti e Pereira, 2007, p.264 e 265.

${ }^{89}$ Idem.
} 


\subsection{A marcha do tricentenário de Zumbi dos Palmares}

Com um símbolo nas mãos, um herói na cabeça e o reconhecimento de que sua luta é um direito, torna-se mais fácil para os movimentos negros ampliarem a dimensão de suas reivindicações. ${ }^{90}$ (Hamilton Cardoso).

Depois do centenário da abolição, o terceiro marco do protesto negro foi a Marcha do Tricentenário da Morte de Zumbi ${ }^{91}$. Os ativistas com experiência de realização de marchas em seus estados ${ }^{92}$ passam a trabalhar por uma manifestação nacional, unificadora do movimento negro já marcado por diversificadas e numerosas organizações. Não poderia ser uma data mais oportuna: o aniversário de morte do guerreiro palmarino. Eis que a marcha pela Explanada dos Ministérios, em Brasília, aconteceu numa segunda-feira do dia 20 de novembro de 1995, na gestão de Fernando Henrique Cardoso.

Cerca de 30 mil pessoas caminharam em rememoração ao tricentenário da morte do herói quilombola, em cuja passeata via-se o seguinte lema: contra o racismo, pela cidadania e a vida". Algumas das palavras de ordem do evento foram captadas pelas filmagens feitas para a elaboração do audiovisual sobre a passeata, o qual, aliás, tem o mérito de coletar imagens e discursos de importantes líderes no calor do evento, contudo apresenta forte viés ideológico, a se notar pelas preferências partidárias e pela quase ausência de líderes de organizações negras rivais. Mas para efeito de nossa argumentação, o filme é uma fonte relevante, em que pese o enfoque nas lideranças da CUT e do PT.

No documentário da Marcha Zumbi dos Palmares ${ }^{93}$, as passagens editadas mostram os ativistas cantando e gritando em alto e bom tom as seguintes frases de efeito: "Reaja a violência racial!"; "Negro também quer poder!"; Palmares! Zumbi! Assim eu resisti!”; “Queremos escola,

${ }^{90}$ Ver Cardoso "O resgate de Zumbi”, p.64.

${ }^{91}$ Essa data já era cotada pelo movimento desde 1971, segundo Silveira, 2003.

${ }^{92}$ No livro 25 anos de movimento negro, o fotografo Januário Garcia (2008) registrou várias caminhadas de protesto em Alagoas, Brasília e sobretudo no Rio e Janeiro ao longo dos anos 80 e início dos anos noventa. Todas tinham como mote principal a homenagem a Zumbi dos Palmares, como a campanha carioca de 1983, cujo o tema era "Zumbi vive". Ao longo desses anos foi construído um consenso em todo país acerca do "Dia Nacional da Consciência Negra", o 20 de Novembro.

${ }_{93}$ O documentário foi realizado pela Ipê- vídeos produções. Dentre os apoiadores encontram se o MNU-DF; CUT: Sindicato dos Jornalistas; Ministérios dos Direitos Humanos, dentre outros. O roteiro e direção foram de Edna Cristina, com narração de Chico Sant'anna e texto e edição realizados por Roberto Menezes. 
queremos emprego!"; “Zumbi vive, Racimo, não!”. Essas cinco palavras de ordem são, provavelmente, apenas algumas dentre vários dizeres coletivos pronunciados ao longo da caminhada. Neles, mesclam-se problemas de ordem econômica, educacional e de representação política, bem como denúncia de preconceito e discriminação, esta última pode ser apreendida, especialmente, pela menção ao caso da violência racial. O enaltecimento de palmares parece se referir a um espaço de liberdade, construído pelo negro em oposição ao sistema de dominação vigente, pois, afinal de contas, como diria o intelectual do movimento Hamilton Cardoso "os homens são homens em qualquer lugar do mundo e desejaram, em todas as épocas viver em liberdade, viver sua humanidade" (p.67). Nesse sentido, mais do que falar do passado, esses símbolos evocam problemas do momento atual, que na interpretação dos atores envolvidos tem suas causas no racismo da sociedade brasileira .

Enquanto as pessoas seguiam o curso da marcha pelas esplanadas, no caminhão de som, levantam-se algumas lideranças e personalidades artísticas e políticas, dentre elas, Benedita da Silva, que durante sua primeira legislatura como deputada federal atuou na Assembléia Nacional Constituinte em favor da causa negra, indígena e de outras minorias. Naquele dia, ela discursava em tom eloqüente: "nós queremos que esse Brasil mostre a sua cara negra e mostre a sua cara com graça e mostre a sua cara com raça e mostre também a mulher brasileira: mostre a mulher negra" "94. Numa evidente demonstração de descontentamento com a representação nacional do brasileiro, a então senadora opõe-se à versão mestiça do país e convoca o orgulho negro, especificamente da mulher negra, uma identidade autônoma que vem ganhando fôlego nos últimos anos em diálogo com o movimento feminista.

\footnotetext{
${ }^{94}$ Discurso extraído do documentário Zumbi dos Palmares.
} 


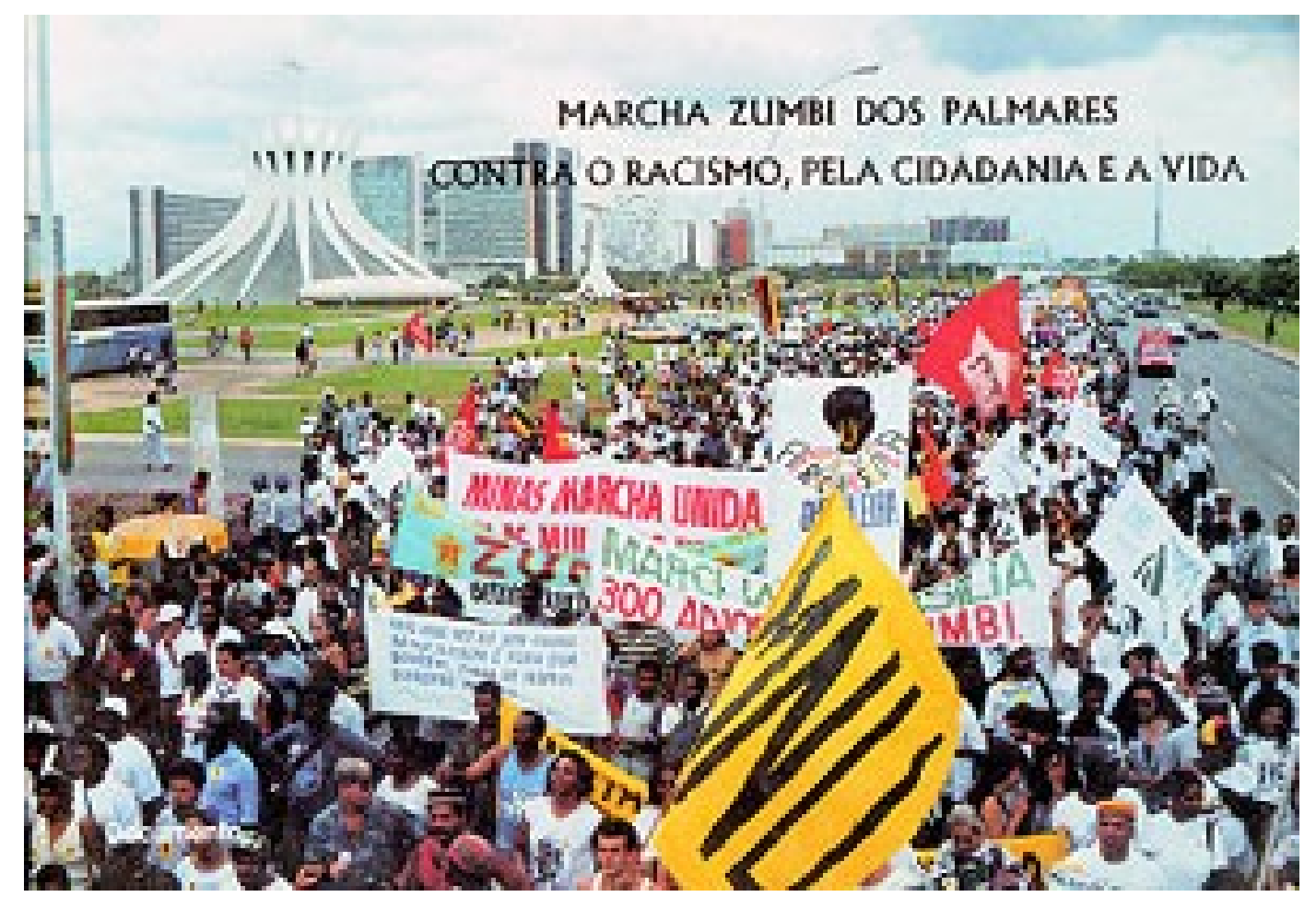

Foto: Januário Garcia, 25 de novembro de 1995 - GARCIA (2007)

Esse evento já acena para um elemento novo em relação às marchas anteriores. $\mathrm{O}$ apoio ao movimento negro parece ter crescido e se tornado mais explícito, composto por alianças diversas como organizações de comunidades rurais, associação de trabalhadores, sindicatos e movimentos populares, só para ficar com alguns exemplos. Bandeiras partidárias se fazem notar ao lado de faixas de organizações sindicais e banners da passeata. E isso foi tão importante para o movimento que um dos membros da comissão nacional da marcha e integrante do MNU, Edson Cardoso, fez questão de deixar registrado no relatório final do protesto o empenho do então presidente da CUT, Vicentinho:

Gostaríamos de fazer uma menção especial à participação de Vicente Paulo da Silva, Vicentinho, presidente da Central Única dos Trabalhadores (CUT), que desde a aprovação da proposta da Marcha levada pelo Movimento Negro unificado (MNU) ao encontro de sindicalistas negros cutistas, realizado em maio de 1995, em Brasília, desempenhou importante papel na garantia da aliança, muitas vezes conturbada, entre o movimento negro e o movimento sindical, sem nenhuma dúvida uma das razões essenciais do êxito alcançado pela Marcha. ${ }^{95}$.

\footnotetext{
${ }^{95}$ Extraído do relatório final da Marcha de Zumbi, de 1995.
} 
O agradecimento ao sindicalista talvez não seja apenas uma referência protocolar, que denota alianças pontuais entre movimento negro e o movimento sindical. Note-se bem que a referência de Cardoso remete ao encontro de sindicalistas negros da CUT, o que denota um tipo de relação mais duradoura e maior inserção do discurso racial naquela organização. Por isso, parece não se tratar somente de uma gratidão pública referente ao empenho contextual e aos apoios eventuais da liderança e de sua estrutura solidarizados com a "causa negra", o que já poderia ser motivos suficientes para palavras de reconhecimento. Se não é exatamente assim, então, que tipo de alianças seriam essas? Que trocas simbólicas estavam em jogo? Quem é esse Vicentinho da Marcha de Zumbi? Seria o mesmo das greves gerais do ABC paulista?

Avento a hipótese de que Vicentinho mais do que apoiar esse protesto como um sindicalista, estava assumindo nacionalmente a identidade negra, como um status político, como uma representação social. Isso pode ser notado pelas roupas que vestia e ainda pelo modo que o sindicalista se portava na marcha ${ }^{96}$. É possível supor que Edson Cardoso ao destacar a figura de Vicentinho já não quisesse somente agradecer a uma liderança nacional do movimento sindicalista, mas acenar para uma liderança oriunda do sindicalismo que emergia timidamente no movimento negro, assumindo assim as filiações identitárias, de negro e de sindicalista ${ }^{97}$. A fala de Vicentinho talvez dispense comentários:

Eu acho que representa a coisa mais importante que está acontecendo hoje no país, o reconhecimento de que o grande herói brasileiro, o maior deles, é Zumbi de Palmares, a denúncia da comunidade negra de que não quer ser excluída e também não quer excluir, ela que ter o direito ao trabalho, a igualdade, o direito a alegria e essa junção aqui dos vários movimentos da sociedade civil mostra porque que o povo está gritando, por essa razão é que nós entendemos que não devemos parar, a partir de agora é que tem que dar mais novos passos ${ }^{98}$.

Nessa marcha, compareceram cerca de 5 mil sindicalistas, conforme afirma Silva Bento (2000), revelando o estreitamento dos laços entre os ativistas negros e os sindicatos, o que não se via no caso dos protestos anteriores. Se o leitor se lembrar, durante os eventos do centenário,

\footnotetext{
${ }^{96}$ Ver documentário da Macha Zumbi dos Palmares.

${ }^{97}$ Essa hipótese se torna mais plausível quando observamos as representações públicas de Vicentinho enquanto legislador. No campo em que realizei esta pesquisa, assisti a dois discursos de Vicentinho, um na marcha noturna e outro no trigésimo aniversário do MNU. Em ambos, declarava-se negro e comprometido com as reivindicações do movimento.

${ }^{98}$ Fala de Vicentinho coletada no dia do evento, extraída do documentário da Marcha de Zumbi dos Palmares.
} 
realçamos que os ativistas reclamaram da ausência do apoio de outras organizações de classe. Então, essa presença expressiva de trabalhadores ligados aos sindicatos sela um compromisso de alianças com o movimento negro, que vem sendo costurada por seus militantes nos últimos anos. O sindicalista da CUT- MG, que participou da Marcha de Zumbi dos Palmares, esteve atento às implicações dessas alianças: "a partir da marcha Zumbi pela Vida não dá mais para o movimento sindical fechar os olhos na questão da luta contra o racismo na sociedade brasileira. E neste sentido a tendência é de ampliar cada vez mais esta aliança" ${ }^{\text {"99. }}$.

As alianças mais intensas entre o movimento negro e o sindicalismo têm sido feitas há duas décadas por meio da inserção de algumas lideranças negras nos sindicatos. Em São Paulo, essa aproximação formal ocorreu com o Conselho Estadual da Comunidade Negra, que promovia articulações e encontros de sindicalistas negros, chegando a designar uma equipe de trabalho só para organizar eventos e debates, através de um setor voltado para as relações de trabalho ${ }^{100}$. Depois do Conselho Estadual, nos anos 90, organizações negras como o Centro de Estudos e Relações de Trabalho e Desigualdades, o CEERT, atuaram fortemente na formação de quadros sindicalistas, cujos resultados se fizeram notar no "surgimento de órgãos [no interior do sindicato] como o objetivo de abordar especificamente a problemática das relações raciais" (Bento, 2000, p.321) e isso ocorreu inicialmente na Central Única dos Trabalhadores, mas logo foi alcançando outras entidades sindicais ${ }^{101}$. As ações conjuntas entre as centrais de proteção do direito trabalhista expressam bem os ganhos do movimento negro no interior do sindicalismo brasileiro, o que pode ser notado nas Conferências Internacionais pela Igualdade Racial, ocorridas no Brasil e nos EUA na primeira metade da década de 90, e na construção do Instituto Interamericano para a Igualdade racial, a INSPIR, organizada pela CGT, CUT e Força Sindical, em 1995, no qual Vicentinho assumiu a direção no status de presidente fundador ${ }^{102}$.

Com esse histórico de articulações, não é de se estranhar empenho desse líder sindical, bem como a presença numerosa de sindicalistas na Marcha do Tricentenário. Nascimento e

\footnotetext{
${ }^{99}$ Depoimento extraído do Vídeo de registro da Marcha Zumbi dos Palmares (1995).

100 "Em 1986, paradoxalmente a partir de uma iniciativa do Conselho da Comunidade Estadual de Participação e Desenvolvimento da Comunidade Negra do Estado de São Paulo, um órgão governamental, foi realizado em São Paulo, o ' $1{ }^{\circ}$. Encontro Estadual de Sindicalistas Negros', que significa um acontecimento importante entre negros sindicalistas" (Bento, 2000, 327)

${ }^{101}$ Por exemplo, em 1990 a Confederação Geral dos Trabalhadores fez no Rio de Janeiro um encontro no qual aprovou a criação de uma Comissão Nacional da CGT contra a discriminação racial. (Bento, 200, 328).

102 Informação extraída do "Histórico e Vida Pessoal de Vicente Paulo da Silva", disponível no site: http://www.vicentinho.org.br . Consulta realizada no dia 15 de outubro de 2008.
} 
Larkin (2000) consideram que essa relação de proximidade entre os dois movimentos é resultante da inserção dos militantes negros nos sindicatos, o que teria sido mediado pelos partidos políticos. Segundo eles, uma vez nas estruturas partidárias, os ativistas teriam acessado os principais sindicatos do país, influenciando-os politicamente. Desse modo, oferecem uma explicação complementar àquela apresentada por Bento, cujo enfoque foi tanto para estruturas estatais como para organizações não-governamentais. O argumento de Nascimento e Larkin parece ainda mais convincente quando atentamos para o depoimento de um ativista negro inserido em partido político. Segundo ele, na época da Marcha dos 300 anos de Zumbi, "do ponto de vista partidário, a gente tinha, em 1995, organizações em quase todos os partidos, seja de direita seja de esquerda: PT, PC do B, PCB,PCB, PDT, PSB, o próprio PMBD, todos eles já tinham agrupamentos negros"103.

Além da maior abertura na sociedade civil, que gerou a possibilidade de assumir compromissos com demais movimentos, a Marcha dos 300 anos da Morte de Zumbi contava com uma abertura maior das estruturas estatais. Assim, esse evento logrou uma sessão solene no Congresso Nacional, em que o movimento tinha o apoio de alguns parlamentares como Paulo Paim, deputado Federal pelo partidos dos trabalhadores do Rio Grande do Sul, que apresentou sua avaliação do evento, bem como as principais pautas das reivindicações negras que defendia no parlamento:

Politicamente esta sessão demonstrou a capacidade da comunidade negra e que ela está se mobilizando em todo país no exercício pleno da busca da sua identidade e da cidadania que infelizmente a nós não é dado e dizendo que nesta sessão também nós temos três projetos básicos. Primeiro: que se re-escreva a história da comunidade afrobrasileira e conseqüentemente dos negros desse país. Segundo: que se consiga assegurar aos remanescentes dos quilombos a titularidade das terras. E o terceiro: a indenização dos remanescentes dos escravos por mais de trezentos anos de trabalho escravo ${ }^{104}$.

Diferentemente de antes, a marcha representava um ritual que culminaria com o encontro entre o presidente da República e a comitiva nacional do movimento ${ }^{105}$. Nesse encontro, alguns

\footnotetext{
${ }^{103}$ Depoimento de Flávio Jorge Rodrigues da Silva concedido a Alberti e Pereira, 2008, p. 349.

${ }^{104}$ Entrevista de Paim concedida para o documentário sobre a Marcha de Zumbi de Palmares, em 1995.

${ }^{105}$ As organizações que fizeram parte da direção nacional do evento são: Agentes de Pastoral Negros (APN's), Cenarab, Central de Movimentos Populares, Confederação Geral dos trabalhadores (CGT), Comunidades Negras Rurais, Central Única dos Trabalhadores (CUT), Força Sindical, Fórum Nacional de Entidades Negras, Fórum de Mulheres Negras, Movimento Negro Unificado (MNU), Movimento Pelas Reparações (MPR), Conun, União de Negros pela Igualdade (UNEGRO) e Grupo de União e Consciência Negra (Grucon).
} 
de seus ministros como Paulo Renato e Edson Arantes do Nascimento, o Pelé, se faziam presentes quando os ativistas entregaram um documento formal no qual apresentava suas reivindicações, "denunciando o racismo, defendendo a inclusão dos negros na sociedade brasileira e apresentando propostas concretas de políticas públicas" ${ }^{106}$. Nos dizeres de Edson Cardoso, esse evento marcava um novo tipo de intervenção do movimento negro junto ao Estado:

Chegamos aqui após percorrermos um longo caminho e acreditamos que a partir desse momento a questão racial deixar de ficar no confinamento do cultural, onde o estado intervem no carnaval liberando verbas para o desfile de bloco. O que a marcha veio exigir da representação política do estado brasileiro é que o orçamento da união defina recursos explicitamente para superar as desigualdades raciais no campo da educação, no campo da saúde, da comunicação e do emprego ${ }^{107}$.

$\mathrm{Na}$ avaliação de Cardoso, há um elemento importante para a política do movimento negro dos anos 90, quando contraposta à década anterior. No plano federal, a conquista do movimento no centenário da abolição foi a construção da Fundação Palmares, um órgão ligado ao Ministério da Cultura, o qual canaliza demandas do movimento ligadas à dimensão cultural, não enfrentando, assim, os problemas de desigualdade, uma vez que o órgão não tinha essas finalidades em sua missão institucional. Ademais, as administrações do estados costumam promover grupos negros apenas durante o carnaval, e isso fica bem nítido na pesquisa de Souza (2006) sobre o Ilê Aiyê no Estado da Bahia. Diferentemente desse tipo de relação que se estendia para o Brasil inteiro, a proposta da Marcha de 1995 tinha um caráter mais ousado: pretendia propor ao Estado o enfrentamento das desigualdades raciais e isso exigia a destinação de verbas específicas para lidar com essa demanda.

A contra-proposta do governo Fernando Henrique não foi outra senão instituir um grupo de trabalho para debater a questão de forma "criativa". ${ }^{108}$ Assim, o resultado da Marcha foi o decreto presidencial que criava um Grupo de Trabalho Interministerial (GTI) com objetivo de

\footnotetext{
${ }^{106}$ Ver documento final de divulgação da Marcha de Zumbi de 1995.

${ }^{107}$ Depoimento extraído do documentário da Marcha de Zumbi dos Palmares.

${ }^{108}$ No seu discurso de abertura do Seminário Multiculturalismo e Racismo organizado em função do GTI, FHC incitou os pesquisadores convidados a serem criativos perante o desafio de construir políticas públicas para população negra. Em suas palavras: "Desafio os senhores: criem. Seguramente, em um grupo tão vasto como este, além da inteligência bem repartida, deve haver alguns com muita criatividade. O governo está tentando explorar a criatividade dos senhores, porque a nossa está esgotada". (1996, p.17).
} 
promover políticas para "a valorização da população negra", em resposta ao conjunto de reivindicações apresentadas em documento ao presidente.

A função do grupo seria estudar propostas para o desenvolvimento e participação da população negra, considerando que para isso seria necessário "propor ações integradas de combate à discriminação racial". ${ }^{109}$ Um ativista do movimento negro carioca que esteve envolvido na Marcha do Centenário da Abolição, e naquela década já tinha fundado sua própria organização não-governamental, o CEAP, Centro de Articulações de Populações Marginalizadas, analisando os desdobramentos do protesto de 1995 apresentou sua avaliação acerca das conquistas do movimento negro:

Pela primeira vez na história do Brasil o Estado brasileiro tem que reconhecer que ele é racista e que a sociedade é racista e isso levou inclusive o governo brasileiro a instituir uma comissão interministerial para tratar políticas públicas para a população negra e isso foi um fato muito importante e foi uma conquista da marcha ${ }^{110}$.

Os ativistas negros envolvidos na marcha construíram um discurso de que o movimento teria pressionado o governo, o qual respondeu imediatamente com a construção do GTI. Isso realmente aconteceu em alguma medida, mas não foi exatamente assim. Um ativista do movimento negro apresenta uma versão diferente, deslocando o protagonismo da Marcha. Ivair Alves dos Santos, que geriu o Conselho da Comunidade Negra do Estado de São Paulo nos anos da re-democratização, atuava naquele momento na gestão de Fernando Henrique Cardoso numa secretaria do Ministério da Justiça, realça uma articulação no interior do estado feita por ativistas e funcionários negros ligados ao governo:

O GTI, como disse, foi praticamente uma reprodução em larga escala do que a gente fez: era abrir espaço etc. e tal. Mas, na verdade, o que nos norteava era criar bases para que as pessoas entendessem que o racismo era uma coisa de política pública e criar algum substrato para discutir ação afirmativa. Quando a marcha Zumbi dos Palmares chegou aqui,deu a impressão de que a Marcha criou o GTI. Mas na verdade o GTI já estava pronto. Foi uma coisa que foi construída no governo. Não foi feita pela sociedade civil. O governo fez e apresentou ${ }^{111}$.

\footnotetext{
${ }^{109}$ Decreto do Presidente da República em 20 de novembro de 1995.

${ }^{110}$ Depoimento de Ivanir dos Santos ao Documentário Marcha Zumbi dos Palmares, em 1995.

${ }^{111}$ Depoimento de Ivair Alves dos Santos concedido a Alberti e Pereira, em 2008, p.355.
} 
Ligado ao Ministério da Justiça, o GTI passou a vigorar em 1996 e possuía representantes de vários ministérios e ativistas do movimento negro, tendo como presidente Hélio Santos, que dirigia na década anterior a primeira gestão do conselho da comunidade negra da cidade de São Paulo. Num evento de abertura do grupo de trabalho, FHC chamou um grupo de intelectuais brasileiros e estrangeiros para debater a temática e apontar algumas possibilidades de ação política, considerando a realidade específica do país. No discurso que inaugurava as atividades, lembrou aos presentes do seu trabalho sobre relações raciais, nos anos 50, como assistente de Florestan Fernandes. Investido de sua autoridade de intelectual, o presidente também assinalou que o Estado brasileiro, àquela época, não admitia a existência de preconceito racial no Brasil, contudo esse não era o entendimento de seu governo. Segundo o presidente, "o Brasil é uma nação multirracial e disso se orgulha, porque considera que essa diversidade cultural e étnica é fundamental para o mundo contemporâneo"112. Mais do que uma sociedade multirracial, o presidente assinalou que o país possuía profundas desigualdades de todos os tipos, inclusive de raça, de cor e de cultura. Diante dessa nossa formação nacional, que guardava uma certa ambigüidade que nos é cara, Fernando Henrique considerava importante buscar soluções para tais problemas de forma criativa e original, sem se render as modelos prontos de outros países. Um fato parecia consensual: era preciso mudanças para reverter o quadro de discriminação racial. Nas palavras dele:

“(...) Há uma repetição de discriminação e há a inaceitabilidade do preconceito. Isso tem que ser desmascarado, tem de ser, realmente, contra atacado, não só verbalmente mas também em termos de mecanismos e processos que possam levar a uma transformação, no sentido de uma relação mais democrática, entre raças, entre grupos sociais e entre as classes" (1996, p.16).

Apesar de um discurso presidencial progressista em relação aos problemas raciais no Brasil $^{113}$, os desdobramentos das atividades do GTI não deram resultados compatíveis ao sofisticado nível de discussão, o qual, aliás, esteve entre assumir os problemas de desigualdade e discriminação racial sem se desfazer da democracia racial como um ideal da nação brasileira. Segundo Sérgio Costa (2006), as discriminações indiretas contra negros, como por exemplo,

\footnotetext{
${ }^{112}$ Discurso de FHC, 1996, p. 13.

${ }^{113}$ Muitos analistas defendem que o discurso de FHC é bastante avançado, pois este estaria reconhecendo a existência de racismo no Brasil e isso era um fato inédito na história presidencial brasileira (Telles, 2003; Nascimento, Larckin, 2001).
} 
àquelas relativas ao sistema educacional não receberam medidas combativas. Já Telles (2003) considerou que "como resultado, o governo Cardoso hesitou na concretização dos objetivos que havia colocado inicialmente"(p.175). Pelo visto, na opinião dos analistas, o GTI parecia ser bastante promissor em relação a medidas concretas para coibir discriminação racial, porém frustrou as expectativas de muitos.

Em que pese os limites do GTI para desenvolver efetivamente políticas públicas, o que nos interessa salientar é que um novo espaço se abria no interior do Estado para a discussão da pauta levantada pelo movimento negro. A relação entre Estado e movimento sofre mudanças ${ }^{114}$. Em certa medida, as autoridades nacionais já passam a admitir a existência de um problema racial no país e a necessidade de criar condições efetivas para resolvê-lo.

Essas mudanças reverberaram sobre o próprio movimento, que interpretou a aquele protesto como uma ação vitoriosa para a mobilização negra de todo o país. Sueli Carneiro, representante executiva da Ong Geledés, avalia que "depois do centenário da abolição, das ações, das marchas que fizemos por conta do centenário, a marcha Zumbi dos Palmares pela cidadania e a vida, de 1995, foi o fato político mais importante do movimento negro contemporâneo" ${ }^{115}$. Certamente, esse evento fortaleceu ainda mais o movimento que passou a usar o repertório da Marcha do Tricentenário em escala estadual e municipal para instituir o feriado do 20 de novembro em diferentes partes do país. Mais do que um evento episódico ou reivindicativo, com o passar dos anos a marcha tornou-se também um evento do calendário da mobilização negra brasileira e tem sido realizada anualmente em diversas capitais do Brasil, mesmo naquelas em que o feriado já é uma conquista ${ }^{116}$.

\footnotetext{
${ }^{114}$ Do ponto de vista dos resultados concretos, o único avanço mais contundente apontado pela literatura ocorreu no campo da saúde. Segundo Monteiro e Maio (2008), "a proposta de uma política com recorte racial na área da saúde pública no Brasil só ganhou visibilidade no Governo Fernando Henrique Cardoso(...)" E acrescentam que essa visibilidade veio no contexto do formação do GTI : "foi nesse ambiente de discussão que ocorreu ainda no primeiro semestre de 1996 a mesa redonda sobre a saúde da população negra", o qual contava com cientistas, ativistas do movimento negros e outros técnicos das áreas de saúde. A inclusão do quesito cor/ raça nos formulários oficiais de nascimento e óbito foi uma das conquistas no ano de 1996. Afora essa conquista, os autores elencam o programa de Anemia falciforme como uma das reivindicações atendidas ainda na vigência do governo FHC. (p.127).

${ }^{115}$ Depoimento de Sueli Carneiro a Alberti e Pereira, 2008, p. 345.

${ }^{116}$ Esse é o caso da Cidade de São Paulo que já possui um feriado municipal e mesmo assim caminha para a quinta edição do evento.
} 


\title{
4.5 Encenando a história: Marcha Noturna pela Democracia Racial
}

\begin{abstract}
"O que aconteceu uma vez volta a acontecer, infinitamente, os visíveis exércitos se foram e resta um pobre duelo de facas; o sonho de um é parte da memória de todos" (Borges, O Fazedor).
\end{abstract}

A marcha noturna pela democracia racial é o exemplo mais bem acabado de um novo perfil de protesto negro no Brasil. Essa marcha ocorre na capital paulista há 12 anos, sem interrupções, desde 1996, quando um grupo de pessoas, às vésperas do 13 de maio, realizou uma caminhada de aproximadamente duas horas pelo centro velho de São Paulo, partindo da Igreja da Nossa Senhora da Boa Morte até chegar à Igreja do Rosário dos Homens Pretos. Em seu histórico, a marcha contou com a participação das principais organizações negras paulistas, sendo a ONG "Instituto Padre Batista" a principal responsável pela sua organização, desde 1997. Naquele ano, a marcha se incorporou ao calendário turístico da cidade, por iniciativa dos seus ativistas, tendo-se difundido por outras cidades paulistas ${ }^{117}$.

Sua fundadora, a advogada Maria da Penha Guimarães, conta que a idéia desse evento nada mais foi do que um sonho, numa época em que "dormia e acordava pensando em negro". As experiências dessa integrante, uma das principais responsáveis pela formação do protesto, são fundamentais para entender a marcha. A trajetória de Maria da Penha ilumina aspectos importantes dos estudos sobre movimentos sociais, porque traz elementos exemplares para pensar o elo de ligação entre o indivíduo e a ação coletiva, especialmente no que se refere ao ato de fundação de uma atividade pública. Sua experiência possibilita entrever as motivações e condições de conexão entre indivíduo e coletivo político. Em particular, ajuda-nos a compreender a estrutura e o simbolismo da marcha noturna do 12 de maio e a sua novidade: a exaltação do protesto litúrgico e expressivo. Para tanto, traçaremos em alto relevo a trajetória individual e a posição da ativista no entrelaçamento das áreas laborais, políticas e religiosas de

\footnotetext{
${ }^{117}$ Esse é o caso de Suzano, uma das cidades da grande São Paulo, que realizou neste ano sua quarta versão da Marcha Noturna, contando com a presença e o estímulo do deputado estadual do PT José Candido. Na Baixada Santista, também contabilizou o quarto ano da marcha noturna, a qual recebeu o nome "Abolição não concluída: 120 anos sem reparações". Algumas das lideranças que organizam a marcha pertencem aos núcleos da Educafro localizados nos municípios do litoral paulista. Essas informações foram extraídas do site da Educafro, em maio de 2008.
} 
sua vida, iluminando os aspectos relevantes de sua experiência para o processo criativo do protesto em tela.

À época de seu sonho, Maria da Penha era integrante da Ordem dos Advogados do Brasil $(\mathrm{OAB})$ e possuía um escritório no Largo do Paissandu, em frente à Igreja do Rosário. Ativista social desde a juventude, formou-se em Direito em Recife e chegou a militar para o Partido Comunista. A pernambucana aporta em São Paulo no final da década de 70 e passa a desenvolver atividades ligadas à sua área de formação até estabelecer o seu próprio escritório de advocacia. Em São Paulo, identificou-se com as questões relacionadas às mulheres e aos negros, chegando a advogar para alguns sindicatos do ABC paulista que, naquele tempo, lideravam as greves gerais do agitado cenário político brasileiro.

Maria da Penha tinha uma larga experiência em militância política e advogava em favor dos casos de discriminação racial ${ }^{118}$. Ela sonhou com uma floresta fechada onde muitos "negros rebelados fugiam por uma mata e iluminavam seus caminhos com tochas, vestidos de preto", seguiam em fuga pela noite. Todos percorriam em silêncio e secretamente buscavam uma forma de chegar a um refúgio seguro. Apavorados, seguiam à procura de saída. No folheto da organização da marcha, encontramos a afirmação de que sua origem estaria atrelada a um "sonho de resistência" e a "um pedido dos orixás".

Impressionada com este sonho, Maria da Penha, que "sempre quis discutir o 13 de maio"119, decide contar para seus colegas de trabalho o que sonhara na noite anterior. Definindose como xangozeira, essa filha de Nanã ${ }^{120}$, considerou que esse sonho poderia ser uma mensagem a ser cumprida, mas não sabia ainda como. Segundo seu relato, naquele momento andava muito "sufocada por conta das palestras", que era o formato vigente para debater o 13 de maio.

Em seu trabalho na OAB, Maria da Penha já tinha encontrado aliados para desenvolver um grupo de trabalho sobre a questão do negro no Brasil, uma vez que já discutia isso na subcomissão da área de direitos humanos. A preocupação fundamental do grupo era com o

\footnotetext{
${ }^{118}$ Dois casos são dignos de nota: o projeto de lei pelas reparações entregue ao presidente da República na Marcha de 1995 e o caso de discriminação da empregada doméstica Simone André Diniz, levado à Organização dos Estados Americanos (OEA).

${ }^{119}$ Entrevista concedida a mim em 16 de maio de 2008.

${ }^{120}$ Nanã é um orixá do panteão religioso do Candomblé. A intenção da informante ao afirmar a relação entre o sonho e sua pertença religiosa era sugerir que recebera uma revelação e, por isso, estava encarregada de cumprir alguns compromissos no mundo.
} 
modo pelo qual a história do país era contada; à época de seu sonho, o problema em pauta era a guerra do Paraguai e a situação do negro naquele período.

Por isso, quando contou o sonho ao grupo, houve receptividade. Segundo ela, as pessoas consideraram importante interpretar esse sonho à luz da luta anti-racista que acontecia naquele momento. A própria Maria da Penha deu uma interpretação para seu sonho: considerava o símbolo da fuga como a tentativa dos escravos de seguir em liberdade, em direção aos quilombos, onde poderiam refugiar-se da escravidão. Interpretou também que se tratava de uma mensagem que acenava para a luta pela liberdade, isso porque estava imersa no trabalho junto ao movimento negro e seu grupo, em particular, confirmava e a responsabilizava por seus próprios sonhos.

Maria da Penha, em conversa com seus amigos da OAB e demais militantes de seus círculos, considerou que a mensagem vinda para ela em sonhos deveria ser traduzida em uma marcha pela luta da igualdade racial. Como disse ter sonhado com escravos, homens vestidos de preto na floresta, considerou que a representação mais condizente com essa realidade deveria apontar para uma mensagem pela abolição. Assim, Maria da Penha decidiu trabalhar para a construção de sua marcha onde pudesse lutar pela "igualdade dos negros na sociedade brasileira", uma vez que esse já era seu ideal de vida antes do sonho da floresta.

Ao tomar esta decisão, Maria da Penha convenceu a direção da OAB a apoiar aquela que veio a ser a $1^{\text {a }}$ Marcha Noturna pela Democracia Racial, que trazia os dizeres: "negro nas ruas na madrugada do 13 de maio". Isso porque, segundo o panfleto, o movimento resolveu "trocar o dia pela madrugada: substituir os discursos pelo silêncio, trajar preto, usar a luz das velas no lugar da confortável luz solar e portar uma tarja branca"121. Na chamada do folheto, está presente aquele que deveria ser, na opinião dos ativistas, um dos maiores desafios da democracia brasileira: o enfretamento efetivo da questão racial. Contudo, longe de apenas denunciar o racismo, a forma de protesto assumida pelo movimento na marcha noturna indicava que eles estavam conscientes de uma nova figuração da relação entre movimento negro e Estado. Senão vejamos: “os símbolos e a maneira de protestar representam as profundas mudanças que estão em curso na sociedade brasileira', resultantes dos esforços da militância negra, que enfatiza a dimensão simbólica e institucional, dentre elas a criminalização do racismo. Do ponto de vista simbólico, segundo o movimento "o mito da democracia racial" teria sofrido "golpes mortais", e a

\footnotetext{
${ }^{121}$ Extraído do documento da primeira Marcha Noturna.
} 
celebração dos 300 anos da morte de Zumbi, celebrados em marcha em Brasília, no ano anterior, seria exemplo disso, haja vista as 30 mil pessoas que teriam comparecido ao protesto, segundo a avaliação do movimento.

Diante desse quadro, foi apresentada a proposta de uma marcha noturna em protesto pela democracia racial, que saiu em caminhada na noite de 12 de maio de 1996. Mas de onde vinha esse sonho que sem grandes esforços, nos lembra discursos coletivamente estruturados pelo movimento negro ao longo de sua trajetória?

\subsection{O repertório do movimento negro contemporâneo}

A idéia da marcha noturna, quando narrada pelos ativistas, remete a duas experiências passadas. Uma foi a Marcha Nacional do Tricentenário de Morte de Zumbi dos Palmares de 1995, servindo-lhes de inspiração imediata, porque ocorreu apenas um ano antes da inauguração do protesto noturno. A segunda referência vem das Marchas pelos Direitos Civis realizada nos EUA durante os anos 60, segundo depoimento de um dos organizadores da marcha pela democracia racial. Do ponto de vista da forma de protesto, é fato que a marcha não é uma inovação política, uma vez que buscava inspiração em dois momentos históricos da luta antiracista, o movimento negro nacional e o internacional. De qualquer forma, cabe notar que essa caminhada, diferente das já citadas, ganha contornos e adornos especiais, levando-nos a perceber que não basta identificar os aspectos estritamente formais do movimento, mas também analisar os contextos particulares de cada ato coletivo. Seguindo as lições de Tilly (2006), vale a pena olhar para os aspectos relativos a difusão de certas formas de organização, sem deixar de fora os conteúdos particulares da ação, dos quais se pode apreender as dimensões criativas do protesto social.

A luta por uma democracia racial não parece nova, mesmo porque a disputa por imprimir um outro significado à expressão "democracia racial" vem sendo realizada desde meados do século XX pelo movimento negro. Guimarães e Macedo (2008) argumentam que esse ideário democrático, numa versão da militância política dos anos 1940, revela certos conteúdos do mito nacional, mas quase sempre apresentam críticas contundentes ao preconceito de cor no Brasil. Ao contrário do que rezava o discurso nacional, a democracia racial negra daquele período 
constituía-se pelo discurso da segunda abolição - divulgada pela Frente Negra Brasileira- e pelas idéias de negritude, de inspiração dos intelectuais negros na França.

Desde então, o discurso pela democracia racial sofreu algumas modificações, Mués (1991 e 1998) identifica nele fissuras significativas. Em seu entender, o movimento de 70 rompe com a idéia de democracia racial tal como formulada pelo Estado e passa a defender uma democracia plena, efetiva para negros, desfazendo-se da idéia de povo mestiço. Esse era, pois, o sentido do discurso da marcha noturna. A proposta permanecia a mesma, denunciar a abolição inconclusa. A questão daquele momento não era apenas denunciar o treze de maio, mesmo porque isto já tinha sido feito na década de 1980, quando o problema de prestar homenagem ao dia da Lei Áurea, em sua versão mais radical, chegou a ser cantado por Oswaldo de Camargo do seguinte modo:

\section{EM MAIO}

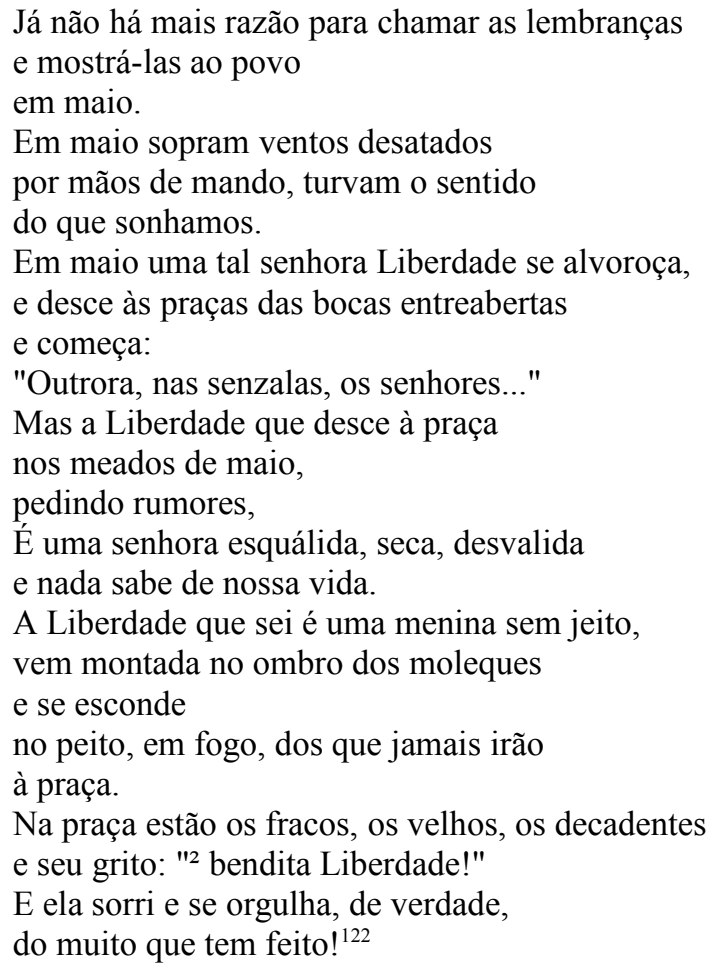

122 Originalmente publicado em O Estado de S. Paulo, 25-1-1987, Cad. 2, p. 5 (informação extraída do site http://brazilianmusic.com/aabc/literature/palmares/oswaldo.html, em 12 de maio de 2008 . 
Escrito às vésperas do centenário da Abolição, não haveria versão mais pessimista do que essa apresentada pelo poeta e ensaísta Oswaldo de Camargo, que foi um exímio lutador pela instituição do 20 de novembro, em oposição ao 13 de maio, data oficial do Estado. A mensagem do poema reflete muito bem uma postura influente no movimento negro, que chegava a negar completamente a possibilidade de qualquer saída às ruas para lembrar o dia da abolição: “Já não há mais razão para chamar as lembranças e mostrá-las ao povo em maio". Na verdade, o autor chega mesmo a defender o esquecimento desta data. Numa versão menos carregada, podemos dizer que Camargo simplesmente não aceitava a possibilidade de comemoração desse evento, uma vez que a liberdade é metaforicamente vista como uma "senhora esquálida, seca, desvalida", satirizando, com isso, a imagem da Princesa Isabel. Ademais Camargo sugere que o vigor físico dos negros já lhes tinham garantido a liberdade, antes mesmo da abolição oficial. Só andariam pelas praças aqueles que não puderam fugir e lutar por sua própria libertação. Por conta disso, "na praça estão os fracos, os velhos, os decadentes e seu grito: "bendita Liberdade!". A tal redenção teria pouco efeito, uma vez que a maior parte dos escravos já teria conseguido sua “alforria" por suas próprias mãos e sua personificação não seria uma senhora, uma heroína rejeitada, mas sim "uma menina sem jeito", que deveria ser cantada por cada negro, mas não de forma comemorativa. A praça tornava-se lugar do Estado, da figura dominante que desconhecia a vida real e concreta dos negros, pois nada sabia " de nossas vidas".

Uma crítica tão acentuada quanto essa foi apresentada pelo cineasta Zózimo Bulbul, em seu filme "Abolição", realizado em $1988^{123}$. Um documentário extenso em que o diretor investe nos discursos dos intelectuais negros, os quais debatem a história da escravidão no Brasil, questionando assim a abrangência dos dois artigos da Lei Áurea. No filme, a princesa Isabel, depois de acentuada discussão com parlamentares, sai à janela e anuncia a extinção da escravidão. Logo em seguida, a câmera se desloca para o povo negro nas ruas em desfile

\footnotetext{
${ }^{123}$ Noel Carvalho traça a trajetória de Zózimo Bulbul, mostrando o quanto esse diretor tinha um vínculo forte com as ideologias do movimento negro. Zózimo, para Carvalho, era uma espécie de porta-voz da militância negra no cinema. Por meio dele, as demandas do movimento negro passaram a ser representadas pela perspectiva cinematográfica. Senão vejamos: “... seus filmes chamam a atenção pela recorrência com que abordam a questão racial, estabelecendo uma correspondência direta com as formulações políticas e culturais do movimento negro na década de 70"(p.11). No final de sua tese, reitera essa idéia: "Os filmes de Bulbul reverberam os pontos de vista do movimento negro sobre a historia e a sociedade. Através deles a identidade negra ganha forma histórica e cinematográfica" (p.248). E sumariza numa outra passagem: "no cinema, Zózimo é o primeiro cineasta a colocar a questão da identidade nos termos com que ela foi posta pelo movimento negro". (p.284).
} 
carnavalesco. A cena abre para uma avenida repleta de fantasias e máscaras, numa visão bem contemporânea do Carnaval carioca: muito samba no pé, mulatas rebolantes, sorrisos fáceis, fantasias belas. Tudo se passa como se a extinção da escravidão fosse uma grande festa, na qual a liberdade pudesse dançar disfarçada de fantasias e máscaras ou simplesmente despida de qualquer pudor. Redenção essa encenada no início do filme, logo depois será objeto de críticas ferozes vindas das principais lideranças do movimento negro daquele período.

Portanto, em São Paulo e no Rio de Janeiro, na poesia e no cinema, vemos uma crítica à liberdade formal cedida pelo Estado brasileiro. Mas não apenas isso. Não é apenas um debate liberal, no estrito senso, em torno do jogo de oposições: liberdade formal versus liberdade concreta. As elaborações dos artistas negros vão além desse par dicotômico. Eles encenam um elemento essencial para a compreensão do movimento: a disputa simbólica pela história da nação brasileira, assim como mostrou Poletta (2006), quando assinala que a narrativa histórica torna-se objeto de litígio dos movimentos sociais em suas investidas públicas. Nesse sentido, a construção do que é ser negro no Brasil, isto é, essa identidade coletiva organizada pela mobilização política, depende do modo pelo qual eles reencenam a história do país. As denúncias, então, recaem sobre certos elementos da identidade nacional que são incompatíveis com narrativa do movimento negro.

Essa mesma visão pode ser encontrada na letra da música do compositor maranhense Tadeu de Obatalá, em que se vê a história “oficial” do Brasil ser criticada, nas passeatas de 1988. Durante o carnaval daquele ano, o bloco Akomabu organizou um protesto contra as comemorações do centenário em São Luis, mas o bloco foi impedido de sair às ruas, porque as autoridades locais suspeitaram que haveria alguma manifestação política. Sem aceitar as restrições do governo, os ativistas negros saíram à avenida de surpresa "no ritmo do bloco (....) com a mão erguida"124, cantando:

13 de maio a nação nagô
não faz festa não
não faz festa não
Em protesto ao dia que diz que o libertou
E marginalizou, jogou na outra escravidão
Eu não vou festejar redentora que a história diz por aí
Redentora pra mim, foi Luiza Mahin, Pedro Ivo, Negro Cosme e o Grande Zumbi
Recusa nação nagô falso herói que a história quer te dar

${ }^{124}$ Depoimento de Magno Cruz concedido a Alberti e Pereira 2008, p. 267. 
Te lembra de heróis que a chibata, o chicote, tentaram sufocar ${ }^{125}$.

Incorporando esse consenso do movimento negro, Maria da Penha e demais ativistas negros decidiram elaborar uma marcha, considerada como uma missão a ser cumprida. Uma mensagem a ser levada à sociedade; mas isso não foi uma decisão consensual, não encontrou de partida a adesão do movimento negro. E o dissenso era da ordem da estratégia e da simbologia. Uma marcha à noite, no treze de maio?

A escolha do dia foi emblemática. O 13 de maio foi considerado pelo movimento negro pós anos 70 como sendo uma data oficial a ser questionada, funcionando como uma denúncia do racismo no Brasil e sendo, assim, rechaçada pelo movimento e seus ativistas. Atenta às formulações do movimento negro, Maria da Penha decidiu por uma data que questionasse o dia comemorativo da abolição, por isso, a do 12 de maio, antes da comemoração oficial, antes do "dia dos brancos", em suas palavras.

Depois de muitas divergências e lutas, Maria da Penha não encontrou muito respaldo dos demais ativistas, pois estes consideravam que, estrategicamente, o movimento não deveria fazer uma marcha noturna, porque não haveria muitas pessoas para acompanhar e aderir a essa atividade de protesto. Sem apoio dos demais integrantes do movimento, Maria da Penha considerou que era um dever pessoal levar às últimas conseqüências a construção de uma marcha. Buscou outras alternativas e como era bem conhecida e respeitada no interior da OAB, conseguiu desta instituição o apoio necessário para a formação da Marcha.

Assim, a primeira marcha pela democracia racial, ocorrida em 1996, um ano depois da de Zumbi, saiu nas ruas de São Paulo com recursos da OAB. Inclusive, seu ponto partida dessa marcha não se deu na Igreja da Boa Morte, como ocorre desde 1997, mas na sede da organização dos advogados do Brasil, cujo apoio foi fundamental para sustentar em termos econômicos e de status a marcha noturna.

Satisfeitos com os resultados produzidos pela primeira marcha, percebendo a possibilidade de que aquele momento poderia se tornar importante para ampliar a discussão em torno do 13 de maio, outras organizações do movimento negro decidiram aderir à marcha. Estrategicamente, a responsabilidade de promovê-la foi deixada nas mãos do Instituto Padre

\footnotetext{
${ }^{125}$ No ano de 1988, Tadeu de Obatalá compôs essa letra para Bloco-Afro Akomabu, em São Luis, do Maranhão.
} 
Batista $^{126}$, uma ONG de origem católica da qual fazia parte Maria da Penha. Desde então, a realização dessa atividade pública recebe apoio de diversas associações negras, terreiros de candomblés, irmandades religiosas e leigas, o que pode ser verificado em anexo. Ademais, seus recursos financeiros e apoios institucionais têm sido dados por sindicatos, por parlamentares e mesmo os governos, através dos conselhos e coordenadoria do Negro. Abaixo, encontra-se um quadro de deputados e vereadores que assinaram XII Marcha pela Democracia Racial, segundo o panfleto distribuído durante o evento:

\begin{tabular}{|l|l|l|}
\hline Deputados Federeias & Deputados Estaduais & Vereadores \\
\hline Janete Pietá (PT) & José Candido (PT) & Beto Cus tódio (PT) \\
\hline Luisa Erundina (PSB) & Paulo Teixeira (PT) & Claudete alves (PT) \\
\hline Paulo Teixeira (PT) & & Francisco Chagas PT \\
\hline Vicentinho (PT) & & Jucelino Cadelha(PSDB) \\
\hline
\end{tabular}

O PT é o partido que mais apóia a Marcha Noturna, o que se nota pelo número de parlamentares que assinaram o documento. Essa proximidade com o partido dos trabalhadores pode ser explicada pelas alianças construídas entre o Instituto do Negro Padre Batista (INPB) e essa organização partidária, como mostrou B'silele (2005) em seu estudo sobre o INPB. Isso se evidencia com o fato de um dos diretores da ONG ser assessor parlamentar do deputado José Candido, o qual, aliás, faz questão de estar presente no evento, assim como o deputado Vicentinho.

${ }^{126}$ O Instituto Padre Batista foi fundado em 1987 pelo Padre Batista, que, por sua vez, esteve envolvido no grupo paulista dos Agentes Pastoral Negros (APNs). 


\title{
4.7 O trajeto da marcha noturna e seus simbolismos: os caminhos e os espaços da
}

\section{história $^{127}$}

\begin{abstract}
"Marchamos porque a história está em marcha e nós mulheres e homens negros (as) também somos construtores da história" (X Marcha Noturna)
\end{abstract}

Às vésperas do 13 de maio, os ativistas da Marcha Noturna percorrem o centro velho de São Paulo em direção ao Largo do Paissandu. Cerca de 350 pessoas, a maior parte ativistas permanentes de organizações negras, caminham pelas ruas em duas filas indianas, que representariam a forma pela qual os escravizados andavam em suas estratégias de fuga. Nas marchas XI e XII , os toques de tambores ritmados ecoam pelas ruas centrais e acompanham os cânticos de candomblés entoados pelo povo de santo.

Nas filas, as pessoas carregam tochas acesas, que são artefatos elaborados para realização desta marcha, espécie de lamparinas artesanais que alumiam a noite escura e ajudam a discernir os caminhos percorridos pelos ativistas. O efeito estético dos fachos de luz guarda uma beleza ímpar.

Além das tochas, os ativistas são recomendados a usar roupas pretas, pois assim sonhara Maria da Penha. Mas, segundo a própria fundadora, essa prática tem sido cada vez mais escassa. Em fila indiana, com tochas acesas nas mãos e roupas pretas - agora cada vez mais coloridas -, os ativistas seguem carregando cartazes das suas respectivas organizações. A idéia da falsa abolição ou abolição inacabada é o slogan que marca as últimas marchas. Na primeira caminhada, essa mensagem estava embutida no lema da "Abolição das Injustiças":

\footnotetext{
${ }^{127}$ A fundamentação histórica dos espaços percorridos pela marcha é atribuída pelo movimento aos esforços de pesquisa do Padre José Enes de Jesus, atual presidente do Instituto do Negro Padre Batista. Segundo seus ativistas, o padre teria feito uma dissertação de mestrado acerca desses pontos históricos levantados pelos ativistas, contudo não tivemos acesso a tal tese. Toda a referência dos lugares em destaque pela marcha foi retirada de documentação pública da própria marcha, das entrevistas com seus fundadores e líderes, bem como da etnografia da marchas XI e XII. Ademais, a verificação da validade histórica das informações obtidas nessa documentação foi realizada a partir de consulta de trabalhos historiográficos correlatos aos temas postos em relevo pela marcha.
} 


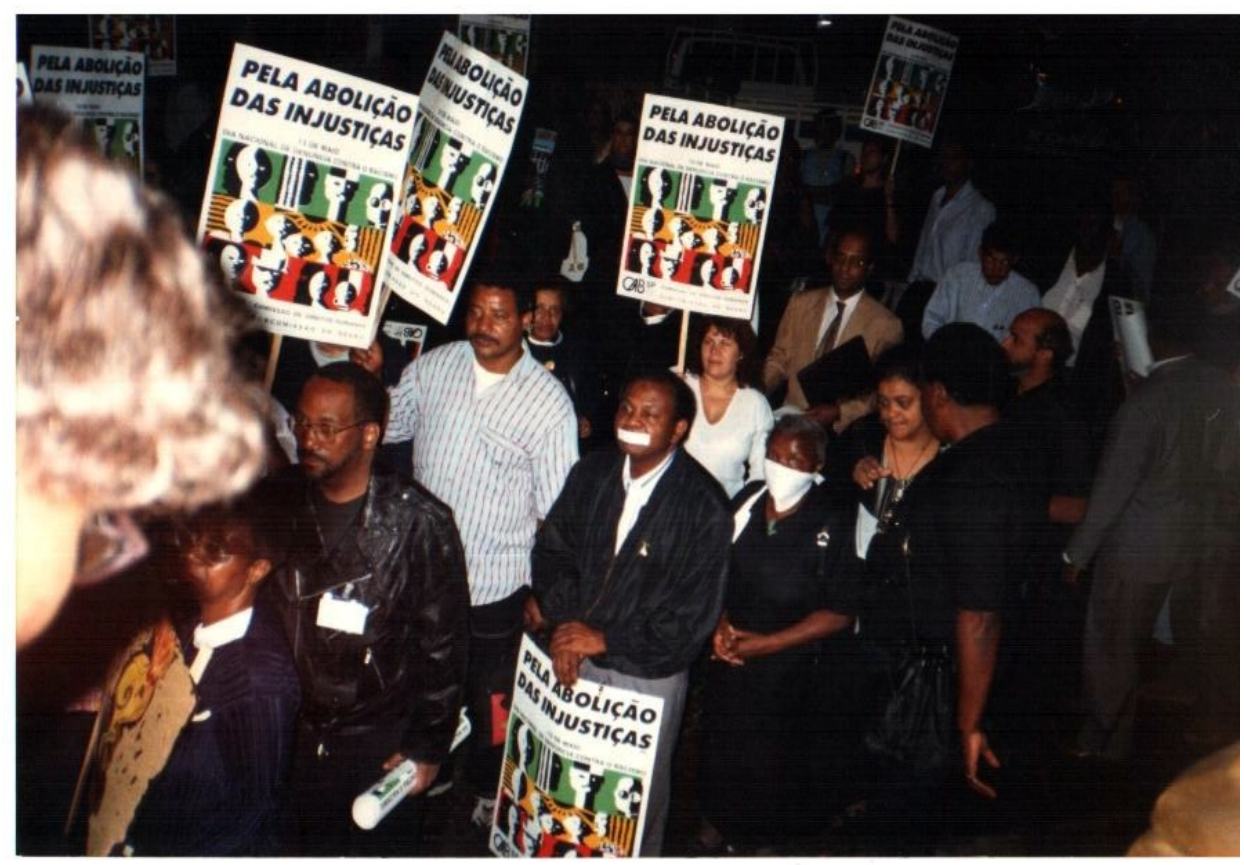

Foto da primeira Marcha Noturna, em 1997. Extraída dos arquivos do Instituto do Negro Padre Batista.

Com o passar dos anos, além dos cartazes, a marcha insere imagens impressas em banners. Trata-se de heróis erigidos pelos ativistas, ilustres e anônimos. Assim, as figuras de abolicionistas - como André Rebouças, José do Patrocínio, Antonio Bento, Luis Gama - e de líderes de revoltas do Brasil escravagista - como Zumbi e Luiza Mahim - são particularmente reverenciadas. Estes últimos figuram no repertório do movimento como grandes heróis da resistência negra da escravidão. Em oposição, a narrativa procura negar ou diminuir a ação dos heróis consagrados pela história oficial, como a princesa Isabel e o abolicionista Joaquim Nabuco. Estes últimos só aparecem nos discursos nos momentos em que as lideranças querem denunciar o fato de que a princesa e Nabuco foram figuras privilegiadas pela História, ofuscando o protagonismo negro na conquista de sua liberdade.

As imagens dos heróis são colocadas lado a lado com líderes do movimento negro do século XX, como Lélia Gonzalez, Hamilton Cardoso, Benedita da Silva, Padre Batista, dentre outros. Esses intelectuais e ativistas importantes do movimento negro percorrem as ruas de São Paulo junto de ativistas anônimos, levados pelas entidades de base. 
A marcha noturna segue um percurso muito particular no centro de São Paulo. A igreja da Nossa Senhora da Boa Morte, localizada na rua do Carmo, na Sé, é o ponto de partida e o lugar de concentração dos ativistas, que ali aguardam a saída da caminhada. Na XII Marcha, os ativistas concentraram-se neste local embalados pelo Hino da Negritude ${ }^{128}$, sons de Rap, grupos de samba e cantos de Candomblé e Umbanda, interrompidos de tempos em tempos por discursos de parlamentares, personalidades históricas e demais ativistas das organizações realizadoras do evento. Mas nem sempre foi assim. A adoção de atividades culturais para incentivar a permanência na espera da saída da marcha foi adotada como uma estratégia para garantir um número maior de pessoas. Trata-se de uma inovação que apareceu aos poucos com a função de constituir uma dimensão lúdica para os integrantes da marcha, atraindo também a atenção dos transeuntes que saem do trabalho.

A escolha da Igreja da Boa Morte, no período da escravidão, era “onde escravos 'rebeldes' e condenados recebiam as últimas 'bênçãos' antes de serem executados"129. Para os organizadores da III marcha noturna: "esta igreja guarda o lamento de escravos condenados que antes da sua execução passavam por ela a fim de expressar a nossa senhora um último desejo "uma boa morte"130.

Os arredores da igreja também são repletos de significados para seus ativistas, por exemplo, na esquina da rua do Carmo, encontra-se a rua Tabantiguera, que "guarda a memória da primeira forca de São Paulo" e a Praça da Sé possuía um pelourinho, rememorado nos discursos realizados pela marcha durante a caminhada. Se o passado escravista era também relembrado neste local, havia um outro significado também importante para os ativistas: a igreja da Boa Morte tornou-se desde os anos 80 a sede nacional dos Agentes da Pastoral dos Negros (APN), os quais são ativos na construção da marcha. Assim, memórias do passado longínquo e recente combinam-se na construção da história contada pelo movimento negro.

\footnotetext{
128 O Hino da Negritude foi composto por Eduardo Oliveira e registrado na Escola Nacional de Música da Universidade do Brasil, em 1966. O próprio compositor, na marcha, rege o canto solene diante da platéia que o acompanha. Algumas passagens da canção merecem destaque, porque convergem com os ideais da marcha noturna: "Que saibamos guardar estes símbolos/De um passado de heróico labor./Todos numa só voz,/Bradam nossos avós:/Viver é lutar com destemor/ Para frente marchamos impávidos/Que a vitória nos há de sorrir./ Eia, pois, cidadãos/Somos todos irmãos/Conquistando o melhor porvir". E no estrebilho, encontra-se: "ergue a tocha no alto da glória/Quem herói, nos combates, se fez/Pois, que as páginas da história,/São galardões aos negros de altivez”.

${ }^{129}$ Documento da X Marcha Noturna.

${ }^{130}$ Documento da III Marcha Noturna.
} 
Saída da rua do Carmo, a marcha segue em direção à praça da Sé, passando em frente à rua Venceslau Brás, onde se localiza a organização Padre Batista, local de ativismo contemporâneo. O largo da Sé lembra também as crianças abandonadas, que, segundo a narrativa, guardava o choro das crianças órfãs, acolhidas e batizadas pelo bispo local.

Depois, seguem em direção ao largo do São Francisco, descem a rua São Bento, chegando à praça Antônio Prado com esquina com a 15 de novembro, onde foi construída a antiga Igreja do Rosário dos Homens Pretos. Lá perto, ao lado da antiga Igreja, encontra-se um cemitério invisível, onde os negros teriam sido enterrados, visto apenas por aqueles que ouvem as narrativas emocionadas ao longo da caminhada.

Mais adiante, avistam-se as escadarias do Teatro Municipal, o penúltimo ponto de parada da marcha. Lá, rememora-se a atitude corajosa do Movimento Negro Unificado, que em plena ditadura denunciou as discriminações raciais, rompendo com o discurso da democracia racial e inaugurando uma nova forma de ativismo político, como já vimos em páginas anteriores.

O ponto final da marcha é o largo do Paissandu, onde atualmente está localizada a Igreja Nossa Senhora do Rosário dos Homens Pretos, erigida em 1904, depois de sair da rua Antônio Prado. A atual igreja ainda guarda os restos mortais, que os ativistas acreditam ser de ex-escravos que atuaram no período da abolição. Ademais, trata-se de uma igreja que abrigava a irmandade negra mais poderosa do Brasil escravagista, a qual tinha liberação jurídica para compra de alforria de escravos. No desfecho XII Marcha, a neta de Solano Trindade leu o manifesto do protesto e depois os ativistas deram um grande abraço na igreja, simbolizando o encontro com seus ancestrais que teriam lutado pela liberdade da escravidão. Assim, mal o 13 de maio se inicia, fecham-se as cortinas da história, para que o dia chegue sem graça, como um outro qualquer, sem ares imperiais, sem a presunção do discurso oficial da República do Brasil. À noite, os negros roubam a cena e o significado do dia da abolição, fortalecendo-o no repertório do movimento social, mesmo que para isso tenham que ajustar os ponteiros do relógio da história.

\subsection{Algumas Considerações}

Ao término do capítulo, talvez o leitor possa concluir que defendi o final da história dos protestos reivindicativos do movimento negro ou que apontei a idéia de que as passeatas e atos públicos não são mais do que encenações do jogo político, já que as "verdadeiras lutas" 
acontecem nas salas de negociação em gabinetes governamentais. Tal conclusão está longe de ser o que proponho em meu argumento. As evidências levantadas mostram que pensar as manifestações pela explicação das oportunidades políticas pode ajudar a entender os ciclos de protestos do movimento negro, uma vez que a maior abertura da opinião pública, do Estado e dos governos oferece incentivos para formação de protestos expressivos, porque os ativistas podem acessar os órgãos decisórios e mover-se com certa liberdade pelos espaços públicos, como os órgãos judiciários de defesa dos direitos humanos, conselhos e secretarias especiais. Por outro lado, quando as instituições e autoridades são menos democráticas ou abertas para negociação, pode haver maiores chances de desenvolvimento de protestos de tipo reivindicativo, caso os ativistas considerem esta a forma mais adequada para expressar suas demandas que são conhecidas atualmente sob a rubrica das ações afirmativas.

Por ora, cabe realçar que o protesto de caráter reivindicativo sempre possuiu elementos expressivos, pois estamos falando de um tipo de manifestação pública que recorre a componentes performáticos para entrar em cena. Do mesmo modo, o protesto expressivo também traz consigo uma pauta de reivindicações, regadas de discursos inflamados contra a discriminação racial e por medidas efetivas de combate às desigualdades entre as raças, isso porque não faz sentido uma mobilização sem causa a ser defendida.

Não se pode perder de vista que o maior acesso aos órgãos e governantes federais não implica necessariamente abertura local. As mobilizações pela implementação das ações afirmativas são exemplos gritantes dessa realidade.

Assim, o protesto reivindicativo ainda se faz presente na cena pública brasileira, apresentando-se de forma marcante na luta pela implementação das ações afirmativas nas universidades públicas. Uma boa parte desses atos é promovida pela Educafro, organização conhecida nacionalmente pelo seu poder de mobilização em favor das cotas nos estabelecimentos de ensino do país. A Rede de pré-vestibulares para afrodesdendentes e carentes - Educafro talvez seja hoje a organização negra com maior poder de mobilização de massas no interior do movimento, isso porque ela se constitui como uma rede articuladora capaz de catalisar cerca de 8.000 pessoas, por conta de sua base social composta por 255 núcleos - concentrados em São Paulo e Rio de Janeiro - e pelos seus mecanismos de controle dos indivíduos vinculados à 
entidade. Certa vez, um de seus integrantes definiu a Educafro como sendo ora uma pastoral católica, ora uma entidade do movimento negro ${ }^{131}$.

O fato é que essa organização é fundamental para as atividades do protesto negro, pois ela tem um grande potencial de mobilização, sobretudo em termos de recursos humanos, organizacionais e financeiros ${ }^{132}$. Certamente, trata-se de uma unidade de mobilização, tal como definida por McAdam (1984; 1998), quando de seu estudo sobre movimento negro nos EUA. Os casos a seguir ilustram bem isso.

Na quinta-feira do dia 19 de julho de 2001, o jornal $O$ Globo, no caderno Cidade, fez uma reportagem sobre o ato público da Educafro na qual dava centralidade para a foto com o Cristo negro atado à cruz, tendo a sua volta dez estudantes amarrados entre si por correntes. O título da reportagem trazia os seguintes dizeres "Sacrifício por uma vaga". A palavra "sacrifício", reproduzida por outros jornais, registrou bem o simbolismo do evento: a imagem religiosa mesclava-se à representação das torturas e dos castigos sofridos pelos negros na escravidão; não por acaso, as correntes grossas nas mãos dos estudantes confirmavam a lembrança do suplício negro.

O protesto, em frente à Universidade Estadual do Rio de Janeiro em 2001, tornou-se emblemático. Além de consolidar a imagem da Educafro como o principal veículo de reivindicação pelas cotas, potencializou essa forma de protesto para os outros lugares. Tratava-se de um ato altamente reivindicativo, e com elevado teor simbólico. O símbolo era apenas uma estratégia de comover o público e constranger as pessoas perante a reivindicação do movimento: a implementação imediata da lei estadual que resguardava vagas para estudantes oriundos de escolas públicas.

Um outro breve relato cabe ser tratado para exemplificar a permanência de atos do tipo reivindicativo. Em 22 de março de 2004, o Jornal carioca $O$ dia noticiava a "Manifestação contra racismo em Shopping”. A reportagem vinha acompanhada de uma fotografia na qual se via um aglomerado de jovens negros em protesto, ao lado estava a explicação: "O shopping São Conrado Fashion Mail foi palco, ontem, de manifestação da ONG Educafro, para marcar o Dia Mundial contra a discriminação racial”. A escolha daquele espaço foi estratégica: um lugar de

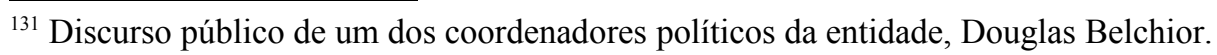

${ }^{132}$ Os recursos organizacionais e financeiros da Educafro provêm da Igreja Católica, quase que integralmente da ordem religiosa da Província Franciscana.
} 
luxo com poucos negros em seus quadros de funcionários. Além disso, "o shopping foi escolhido depois que Luciano Ferreira da Silva, filho de criação do cantor Caetano Veloso, foi expulso pelo PM e segurança particular Leonardo de Medeiros", situação essa tomada pelos ativistas como evidência de discriminação racial. Segundo o noticiário do jornal da Educafro sobre o mesmo evento, "cerca de 100 alunos munidos de um formulário e com grande espírito de cidadania, foram às lojas constatar o número de negros que lá trabalhavam. O resultado demonstrou que $98 \%$ dos funcionários das lojas eram brancos" ${ }^{" 133}$. O jornal da entidade terminava a reportagem elogiando os ativistas e conclamando para "a próxima aula de cidadania".

Em concomitância, outras formas de simbolismos sobrepõem-se às dimensões reivindicativas do movimento, revelando facetas mais complexas. $\mathrm{O}$ aniversário de 30 anos do MNU, ocorrido em 18 de julho de 2008, exemplifica o caso de uma manifestação simbólica em que o movimento conta sua história para si mesmo. Tratava-se de uma atividade que buscava percorrer, de forma ritualística, o mesmo caminho da marcha de 1978, quando saíram do Paissandu em direção às escadarias do Teatro Municipal na cidade de São Paulo. Se naquele ato de 1978 o movimento contava com mil pessoas, dos quais muitos eram simpatizantes políticos; no ato de hoje não mais que cem ativistas fortemente engajados em organizações negras compareceram à atividade comemorativa.

As poses para as fotografias e os arranjos cinematográficos para as filmagens revelam um quadro novo, mesmo optando-se pela moldura antiga. Diferentemente de 1978, o ato do trigésimo aniversário do MNU contava com apoio da CUT, Prefeitura de São Paulo, Governo Federal e diversos outros sindicatos, assim como vimos em todas as marchas desde a década de 90 . Reunidos na mesma escadaria, os velhos militantes históricos de diferentes partes do país, aliados partidários conquistados ao longo da trajetória do movimento (como Vicentinho-PT e José Candido- PT) e lideranças negras juvenis reuniam-se para rever os velhos amigos e recontar a história das escadarias do Teatro Municipa ${ }^{134}$. Ninguém ousava sair do ato sem ter posado junto aos banners dos militantes ilustres, aguerridos ativistas da luta contra o racismo no Brasil.

\footnotetext{
${ }^{133}$ Chamada do Jornal da Educafro do mês de Abril de 2004.

${ }^{134} \mathrm{O}$ documento de divulgação do ato público foi assinado pelas seguintes organizações negras: Movimento Negro Unificado (MNU), Associação de Pastorais Negras (APNS), Encontro Nacional da Juventude Negra (ENJUNE), Congresso de Negros e Negras (CONEN), Fala Negão, Ceabra, Circulo Palmarino, Fórum de Mulheres Negras, Articulação Política da Juventude Negra e Unegro.
} 
Entre os vivos, pousavam as figuras canônicas de Lélia Gonzalez, Hamilton Cardoso, Clóvis Moura e Antônio Leite.

Salta aos olhos os novos quadros do movimento: a juventude negra aceita receber o legado histórico da mobilização dos anos 70. Uma segunda geração de movimento apresentava-se em forma, sendo uma pequena parte composta por filhos biológicos e parentes dos militantes antigos. Mas os discursos sobre a questão racial primavam pela mesma tônica do passado, como se nada tivesse mudado. De fato, os problemas enfrentados pelos ativistas ainda permaneciam. A lista de denúncias talvez não fosse menor que a de antes, nem os casos diferiam em nada daqueles expostos trinta anos atrás ${ }^{135}$. O mesmo grito de denúncia contra a discriminação racial fazia-se ecoar nas escadarias de hoje.

Contudo, o tom do discurso na manifestação já tinha perdido o caráter de ruptura de 1978. As falas do movimento carregavam-se de um tom saudoso daqueles tempos em que os negros foram para a rua protestar... Encenava-se mais a história do movimento negro que contestava a ordem estabelecida. Com duração de uma hora e meia, o ato de 30 anos de MNU, encerrou-se com cânticos de negritude ${ }^{136}$. Findo o ato, os ativistas saíam com seus espíritos renovados, crentes de que seu papel ainda estava por ser cumprido.

\footnotetext{
${ }^{135}$ As denúncias apresentadas no panfleto são: 1) Contra a discriminação racial de jovens do movimento negro em restaurante na cidade de Campinas. 2) Contra o assassinato dos três jovens negros entregues a traficantes por soldados do Exército Brasileiro. 3) Contra a agressão de Skinheads a homem negro e ao policial que interviu (sic) e foi também agredido na cidade de São Paulo. 4) Contra a intolerância religiosa de evangélicos reacionários a templos, comunidades e pessoas de religião de matriz africana. 5) Contra a ação de grileiros, empresas nacionais e multinacionais, que tentam roubar as terras quilombolas de Caçandoca e outras regiões do país". Informações retiradas do documento de divulgação confeccionado para o evento.

${ }^{136} \mathrm{O}$ samba cantado foi: "um sorriso negro/Um abraço negro/Traz felicidade/Negro sem emprego/Fica sem sossego/ Negro é a raiz da liberdade ( bis)/Negro é uma cor de respeito/Negro é inspiração/Negro é silêncio é luto/Negro é a solidão/Negro que já foi escravo / Negro é a voz da verdade/Negro é destino, é amor/Negro também é saudade/" , de autoria de Jorge da Portela e Adilson Barbado, e conhecido popularmente pela interpretação de Dona Ivone Lara.
} 


\section{CONSIDERAÇÕES FINAIS}

O movimento negro brasileiro passou por um processo de institucionalização jamais visto em sua história. Mas essa história ainda está por ser escrita. Nesta dissertação, levantei as evidências flagrantes desse processo, o qual se verifica de forma mais marcante na década de 1990, mas já vem sendo gestado desde os anos de 1980 com a abertura democrática do país, que, em certa medida, possibilitou a profissionalização e a especialização dos ativistas, bem como a formalização e a burocratização dos coletivos e das entidades. Muitas destas tornaram-se, aos poucos, associações civis formalmente mais complexas, cujo modelo exemplar é o de organização não-governamental (ONG).

Se o ambiente de contestação social dos anos 70 favoreceu o surgimento da mobilização negra como afirma Gonzalez (1983), o crescimento e a diferenciação do movimento dependeram, dentre outras coisas, do modo como os ativistas relacionaram-se com o Estado, com outras autoridades civis (Igreja, partidos, imprensa, ONGs) e com os demais movimentos, especialmente o feminista e o sindical. Tão importante quanto isso foi o ambiente político internacional que ofereceu incentivos políticos e econômicos para a luta anti-racista do país, seja na forma de conferências internacionais promovidas pela ONU (Santos, 2005), seja pelo apoio financeiro de agências financiadoras internacionais, como a Fundação Ford (Telles, 2003).

Esse conjunto de fatores levou a uma nova forma de organizar o ativismo político, que parece ter sua gênese no período preparatório do Centenário da Abolição e seus desdobramentos no início da década de 1990, com destaque para o I Encontro Nacional de Entidades Negras (ENEN), em 1991. Este último evento evidenciou a perda de poder do MNU no interior do movimento negro (MENDONÇA, 1996). Assim, a entidade que protagonizou a re-fundação da ação coletiva anti-racista das últimas décadas, passa a atuar na cena nacional como uma organização negra "histórica" - modelada nos métodos de militância dos anos 70 e 80 cujo emblema era a formação de núcleos de "denúncia contra o racismo" -, cedendo lugar para um novo tipo de intervenção social adotada pelas organizações não-governamentais ${ }^{137}$.

\footnotetext{
137 A literatura sociológica não deixa de assinalar as dificuldades de conceituar teoricamente a expressão “organização não-governamental” (Teixeira, 2003), que foi cunhada pela ONU, logo após a Segunda Guerra Mundial, para nomear os certos grupos organizados que não faziam parte da esfera do Estado. No Brasil, essa expressão foi difundida no período da Conferência das Nações Unidas para o Meio Ambiente e o Desenvolvimento (CNUMAD), que ficou conhecida como Eco 92, na qual alguns ativistas negros, sobretudo as organizações de
} 
Como efeito, o intervalo de tempo que compreende o processo de preparação do centenário da abolição e a construção do ENEN, vê-se a emergência das principais organizações negras da atualidade, como é o caso do Maria Mulher (1987), Instituto do Negro Padre Batista (1987); Geledés - Instituto da Mulher Negra (1988); UNEGRO - União dos Negros pela Igualdade (1988); CEAP - Centro de Articulações de Populações Marginalizadas, (1989); CEERT - Centro de Estudos das Relações de Trabalho e Desigualdades, (1990); Casa de Cultura da Mulher Negra (1990), Soweto Organização Negra (1991); Criola (1992) e o Steve Biko (1992). Nesse período, portanto, emergem as primeiras organizações não-governamentais do movimento negro.

Por conta desse histórico, o termo "ONG" é, hoje, bastante referido neste movimento social, sobretudo quando se quer tratar das entidades que desenvolvem projetos sociais. Mesmo quando as associações não se constituem uma pessoa jurídica são recorrentemente assim nomeadas. Os membros da Educafro, cuja representação legal faz-se pela Província Franciscana, utilizam a sigla para classificar sua instituição. Mas não se trata apenas de uma auto-nomeação, órgãos midiáticos e pesquisas acadêmicas também costumam se referir à Educafro e demais organizações do movimento negro enquanto "ONG".

No conjunto das representações do ativismo negro, a palavra "ONG" serve para classificar as entidades que prestam serviços sistemáticos a setores da população, o que exige uma forma administrativa própria e recursos financeiros regulares para sua manutenção. Desse modo, o caráter técnico-administrativo e profissional das entidades é evocado nos contextos em que os militantes recorrem a essa sigla para distinguir esse tipo de associação dos outros grupos e coletivos do movimento social a que pertencem. Mais do que a referência a um status jurídico determinado, a nomenclatura é acionada pelos agentes para designar um modelo de gerenciamento de recursos para a consecução de projetos sociais. Assim, "ONG” é a categoria social que expressa o modo pelo qual os próprios ativistas representam a institucionalização do movimento negro contemporâneo.

$\mathrm{Na}$ nomenclatura deste trabalho, no entanto, estas organizações do movimento negro estão compreendidas na categoria de estrutura de mobilização (McAdam,1982; 1999). Elas

mulheres, participaram ativamente (Roland, 2003; Santos, 2005). Em geral, as ONGs têm sido definidas como organizações de direito privado, sem fins lucrativos, com finalidades diversas, que desempenham o papel de "assessoras" dos movimentos sociais. (Heringer, 2000). 
gerenciam e oferecem recursos jurídicos, humanos e econômicos às investidas da ação coletiva negra, o que pôde ser visto nas articulações dessas entidades para a promoção dos protestos ao longo destas últimas décadas, como se observou no quarto capítulo desta dissertação. Ademais, essas organizações ligam-se geneticamente ao movimento negro, compartilhando com ele sua identidade e seus ideais de luta, como se verificou no caso da Educafro. Para efeitos analíticos, elas representam também uma das mais fortes evidências do processo de institucionalização desse movimento social.

Esse processo, no entanto, não afetou o ativismo negro de forma homogênea, sendo possível identificar zonas mais ou menos institucionalizadas no interior do movimento. O maior ou menor grau de institucionalização depende da aquisição de certas competências e recursos para participar do jogo político. Nem todos optaram por atuar na disputa institucional; muitos não conseguiram atingir as exigências necessárias para desempenhar os papéis da dinâmica do poder. Mas o movimento como um todo, em alguma medida, compreende e participa da lógica política em sua nova figuração.

Um dos elementos que distingue a forma organizativa contemporânea da do passado é o modo pelo qual as entidades acessam os recursos econômicos. Antes, as organizações negras possuíam bases materiais mais frágeis, pois dependiam quase que exclusivamente de donativos dos seus filiados, exigindo esforços para arregimentar o maior número possível de pessoas. A entidade mais expressiva da primeira metade do século XX, a Frente Negra Brasileira “(...) se mantinha basicamente dos recursos oriundos das mensalidades dos associados e das contribuições de delegações (núcleos que representavam a entidade nas cidades do interior e de outros Estados)" (Domingues, 2005, p. 92).

Além das doações dos filiados, as associações negras se valiam das redes de solidariedade, fomentadas e estabelecidas ao longo da trajetória da militância política. Essas redes eram construídas com pessoas de autoridade local ou em posições econômicas mais influentes, como profissionais liberais (médicos, advogados, contadores, professores, engenheiros) ou ainda com indivíduos (negros ou não) que galgavam algum status político. Tanto os simpatizantes como os militantes ilustres da organização são fundamentais para mobilizar recursos materiais utilizados nos trabalhos desenvolvidos pelas entidades. Essa foi, por exemplo, a forma encontrada pela União dos Homens de Cor, uma organização emergente no pós-guerra, 
que se utilizava da influência de suas lideranças e do respeito que conquistou para estruturar sua ação coletiva ( Joselina Silva, 2005).

Uma outra estratégia para manter atividades organizacionais era a promoção de eventos, gincanas, desfiles, cursos etc, com vistas a arrecadar alguma soma em dinheiro para a subsistência dos projetos que realizavam. A venda de materiais, como jornal ou boletins informativos também foi uma forma de obter fundos a fím de cobrir os custos básicos da suas atividades políticas e sociais. Isto, juntamente com a cotização dos militantes, permitia a sustentação precária das entidades, como pode ser verificado nas descrições feitas por Joana Silva (1994), ao estudar o CECAN- Centro de Cultura e Arte Negra em São Paulo.

As organizações negras existentes na década da redemocratização, em alguma medida, recorreram a essas formas de mobilização de recursos. Isto é, também se valeram das redes pessoais e influências de suas lideranças para estruturar-se. Assim, a formação de grupos e das associações dependeu de contatos ou inserção que tinham em sindicados, centros religiosos, universidade, clubes, igrejas, partidos, dentre outros. Somente no final dos anos de 1980, que esse quadro começaria a sofrer as transformações que moldam o perfil do ativismo negro contemporâneo.

A forma de sustentação material das entidades foi um locus privilegiado para as mudanças que geraram uma diferenciação crescente no movimento, tornando-o mais institucionalizado. $\mathrm{O}$ estatuto do CEERT, Centro de Estudos de Relações de Trabalho, oferece elementos sobre o novo modo pelo qual as organizações mais influentes do movimento negro atual passaram a operar. $\mathrm{O}$ que há de novo, para além da forma de obter recursos financeiros via associados, é a possibilidade de estabelecer acordos com instituições de fomento:

Capítulo V: Disposições gerais e finais:

Artigo 23- Constituem recursos financeiros do CEERT: I: Contribuições ou dotações periódicas dos sócios.

II: Recursos oriundos de doações, contribuições, acordos ou contratos, termo de parcerias, direitos ou créditos oriundos de qualquer pessoas física ou jurídica, pública ou privada, nacional ou estrangeira;

III: Produto de operações financeiras;

IV: quaisquer outras receitas auferidas licitamente e não conflitantes com os objetivos do CEERT; rendas decorrentes da exploração de seus bens inclusive Aquiles resultantes da propriedade intelectual; rendimentos auferidos na promoção de cursos, eventos, palestras e vendas de produtos e produções que a associação esteja envolvida ${ }^{138}$.

\footnotetext{
${ }^{138}$ Extraído do estatuto do CEERT.
} 
A citação indica que as formas de captar recursos ampliaram-se e foram formalizadas juridicamente, até mesmo porque esse tipo de estatuto é uma das exigências primeiras para estabelecer-se num mercado de competição de recursos financeiros. Uma outra mudança flagrante é a diversificação das possibilidades de conseguir financiamento, o que favoreceu o estabelecimento de acordos institucionais com empresas, órgãos públicos e demais agências de fomentos. Além disso, a luta por recursos econômicos não precisaria se restringir aos limites do Estado-nacional.

Esse novo quadro ofereceu um leque de opções maior para sustentação econômica das associações, desfazendo-se praticamente das velhas formas de arrecadação financeira. Como conseqüência, o número de associados das organizações reduz-se, uma vez que já não existem mais grandes campanhas para arregimentar sócios. A forma de associar-se às ONGs basea-se em indicação segura e rigidamente controlada.

Com essa nova forma organizativa, impulsionada pela economia e finanças nas associações, os indivíduos que se ligam à organização não possuem possibilidades "reais" de eleger seus representantes. O caminho de entrada nessas entidades é outro: ou são atendidos enquanto público-alvo, ou tornam-se "funcionários das entidades" e prestadores de serviços. As empresas e órgãos estatais tornam-se parceiros, notadamente constituindo a base material dos projetos, o que leva a formação de laços mais formais entre instituições e as associações.

A diretoria da organização é quase sempre eleita por um conselho seleto ou é nomeada por um poder superior, como no caso de organizações ligadas à Igreja Católica. Em geral, uma liderança é selecionada como representante executivo, quase sempre sendo a liderança fundadora, a qual conta com seu tempo de militância, sua autoridade frente à opinião pública, sua experiência de gestão, seus conhecimentos profissionais e suas redes de influência externas. Mais do que isso, a rede pessoal, os favores concedidos ao longo dos anos e o carisma das lideranças contribuem para o alto grau de personalismo presente nas organizações.

Embora o personalismo ainda seja uma marca constante no perfil das lideranças negras, suas redes de influência são cada vez mais profissionalizadas. Com um grau mais profissional, o ativismo político passa a ter como prerrogativa um conjunto de conhecimentos técnicos, 
acadêmicos e científicos, seja para elaboração de projetos sociais, seja para oferecer uma assistência qualificada aos gestores de políticas públicas.

O nível mínimo de escolaridade dos ativistas das ONGs tem sido o título de graduação, quase sempre, com especialização em alguma área relevante de intervenção do movimento negro. Os funcionários e assessores das entidades, que auxiliam suas lideranças, são profissionais qualificados nas áreas em que atua a organização. Dessa realidade, compartilha a Educafro, como vimos no capítulo terceiro. Se antes as entidades dependiam exclusivamente da solidariedade dos indivíduos, assim como da dedicação acentuada de seus ativistas mais comprometidos e lideranças fundadoras; hoje tal solidariedade convive com um modelo de gestores de projetos sociais, que ganham cada vez mais proeminência.

Desse modo, as organizações se inserem numa dimensão burocrática, administrativa e técnica, que não se expressa apenas em seu desenho institucional. Um grau elevado de profissionalismo tem sido necessário para o desenvolvimento e sustentação dos projetos sociais. Nessas estruturas de mobilização, coexistem indivíduos com perfis de liderança política - na figura do "militante" construída no protesto - e a nova figura cada vez mais em destaque: o "funcionário" e o "assessor", que prestam serviços às organizações e tornam-se especialistas na gestão de demandas relativas à população negra.

Este é o quadro contemporâneo do ativismo negro sobre o qual se abrem várias perspectivas analíticas. De fato, a institucionalização do movimento negro no Brasil exige um olhar cada vez mais arguto dos estudiosos. O crescimento e êxito da ação coletiva negra têm dependido cada vez mais de sua habilidade para aliar-se a setores da sociedade civil e do Estado, que a menos de três décadas conferiam pouca atenção às demandas do movimento. O impacto desta configuração de poder sobre a militância e suas investidas na esfera pública nacional pode ter alterado significativamente as relações entre raça e política na sociedade brasileira. $\mathrm{O}$ trânsito de militantes negros no poder executivo, legislativo, o acesso constante ao judiciário, a existência de órgãos públicos destinados exclusivamente às chamadas "políticas de igualdade racial", o progressivo engajamento de deputados e senadores negros nas pautas do ativismo, sugerem campos de pesquisas ainda não contemplados pelos chamados estudos das relações raciais. Com efeito, o significado da democratização para os movimentos e os afro-brasileiros é uma história em aberto. 


\section{REFERÊNCIAS BIBLIOGRÁFICAS}

AGIER, Michel. (1992) “Etnopolítica - a dinâmica do espaço Afro-baiano”. In: Estudos AfroAsiáticos, Rio de Janeiro. N. 22.

ALBERTI, Verena e PEREIRA, Amílcar (2007). Histórias do Movimento Negro no Brasil. Rio de Janeiro. Fundação Getúlio Vargas/ Pallas.

ALONSO, A.; COSTA, V.; MACIELD.(2007). "Identidade e estratégia na formação do movimento ambientalista brasileiro". In Novos Estudos. São Paulo, CEBRAP, v. 79, p. 151-167.

ALVAREZ, S; DAGNINO, E; Escobar, Arthur (2000). Cultura e Política nos movimentos sociais latino-americanos. Belo Horizonte, Ed. UFMG.

ANDREWS, George Reid.(1991) “O protesto político negro em São Paulo - 1888-1989” In. Estudos Afro-Asiaticos, Rio de Janeiro. N. 21

AZEVEDO, Célia Maria Marinho.(2004). "13 de Maio e Anti-racismo”. In Anti-racismo e seus paradoxos. Anna-blume.

AZEVEDO, Thales (1996). As elites de cor numa cidade brasileira. Bahia, Edufba.

BAIRROS, Luiza (1996). "Orfeu e poder: uma perspectiva afro-americana sobre a política racial no Brasil”. Revista Afro-Ásia, n.17 p.173-185.

BARBOSA, Muryatan (2004). Guerreiro Ramos e o personalismo negro. São Paulo. São Paulo, Dissertação de Mestrado-FFLCH-USP.

BARCELOS, Luiz C. (1996) "Mobilização racial no Brasil”. Revista Afro-Ásia, Bahia. n.17.

BARRETO, Raquel de A.(2005). Enegrecendo o Feminismo ou Feminizando a Raça. Rio de Janeiro. Dissertação de Mestrado da PUC-RJ.

Bas'llele (2005). Poder simbólico alternativo e identidade étnica no Brasil: estudo do Instituto do negro padre batista na sua luta pelos direitos de igualdade racial. Universidade Metodista. Dissertação de Mestrado. São Paulo.

BASTIDE, Roger. 1951. "A Imprensa Negra do Estado de São Paulo", IN: Boletim da Faculdade de Filosofia da Universidade de São Paulo, vol. CXXI, nº. 2, p. 50-78.

. (1955). "Efeitos do preconceito de cor" In: Relações raciais entre negros e

brancos em São Paulo. Bastide e Fernandes (Orgs.). São Paulo. Editora Anhembi.

São Paulo, Editora Perspectiva.

(1973). “A Imprensa Negra do Estado de São Paulo" Estudos Afro-brasileiros.

(1976) "Negritude et integration nationale". In:Afro-Ásia, Bahia. N. 12, pp.

$17-30$. 
BENTO, Maria Aparecida Silva (2000). "Racismo no Trabalho: o movimento sindical e o Estado”.In: GUIMARÃES e HUNTLEY (orgs). Tirando a Máscara. Paz e Terra. São Paulo: Paz e Terra.

BILDEN, Rudingen (1929). "Brazil, Laboratory of Civilization”, New York, The Nation.

BOURDIEU, Pierre (1998). A ilusão biográfica. In: FERREIRA, M e AMADO, J. Usos e Abusos da História Oral. Rio de Janeiro: FGV.

BLUMER, Herbert (1942). "Race Prejudice as a Sense of Group Position" Pacific Sociological Review, I (Spring).

BULMER, Martin (1985) “A escola de Chicago de sociologia: o que a tornou uma escola?" Tradução de Mario Eufrásio. Originalmente publicado pela Revista History of Sociology: an Internacional Review- Vol 5, n. 2.

BUTLER, Kim (1998). Freedoms Given, Freedom Won. Rutgers University Press.CASHMORE, Ellis (2000). Dicionário de relações étnicas e raciais. São Paulo. Selo Negro.

CAMPOS MELO JUNIOR, João Alfredo Costa de (2007). "A ação coletiva e seus intérpretes. As perspectivas teóricas de Charles Tilly e Marcur Olson”. Paper apresentado na Associação Nacional de História (ANPUH).

CARDOSO, Fernando Henrique (1997). "Pronunciamento do Presidente da República na Abertura do Seminário Multiculturalismo e Racismo". In: Multiculturalismo e Racismo: o papel da ação afirmativa nos Estados democráticos contemporâneos/ SOUZA, Jessé (ORG). Brasília: Ministério da Justiça.

CARDOSO, Hamilton.(1986) "O Resgate de Zumbi". In: Lua Nova. Cultura e Política.vol.2, no. 4, janeiro-março.pp. 63-67.

.(1987). "Limites do confronto racial e aspectos da experiência negra no Brasil". In: SADER, Emir (Org.) Movimentos sociais na transição democrática. Ed Cortez.

CARDOSO, Ruth.(1987) "Movimentos Sociais na América Latina". In Revista Brasileira de Ciências Sociais. São Paulo, N.3 Vol.1

- (1994) "A trajetória dos movimentos sociais" In Anos 90, política e identidade no Brasil. DAGNINO (org). São Paulo Ed. Brasiliense.

CARNEIRO, Sueli; SANTOS, Thereza; COSTA, Albertina G. de Oliveira (1985). Mulher Negra/ Política Governamental e a Mulher. São Paulo. Nobel. Conselho Estadual da Condição Feminina.

CARNEIRO, Sueli (2003). "Mulheres em Movimento" In: Estudos Avançados 17 (49). São Paulo.

CARVAlHO, Cristina H. A.(2006). “O Prouni No Governo Lula E O Jogo Político em Torno do Acesso ao Ensino Superior”. Educ. Soc., Campinas, vol. 27, n. 96 - Especial, p. 979-1000. 
CARVAlHO, J. C. B; FILHO, H. A. ; COSTA, Renato Pontes.(2005). Cursos pré-vestibulares comunitários". Rio de Janeiro, Editora PUC-Rio.

CARVALHO, José Murilo (2005) "O exército e os negros" In: Forças Armadas e Política no Brasil. Jorge Zahar Editor. Rio de Janeiro.

CARVALHO, Noel (1995). Cinema e representação racial: cinema negro de Zózimo Bulbul. Tese de doutorado/USP. São Paulo.

CATANI, Afrânio M.; HEY, Ana P.; GILIOLI, Renato de S. P.(2006) PROUNI: democratização do acesso às Instituições de Ensino Superior? IN: EDUCAR. Curitiba. Editora UFPR. N. 28, p. $125-140$

COHEN, Jean (1985). "Strategy or Identity: New Theoretical Paradigms and contemporary social movements". Social research, Vol.52. n.4.

COHEN, L. Jean; ARATO, Andrew (2000). "Los movimientos sociales y la sociedad civil". In Sociedad civil y teoría política. México, Editora mexicana Fondo de Cultura Econômica.

CONTINS, Márcia (2005). Lideranças Negras. Rio de Janeiro, Faperj e Aerplano.

COSTA, Sérgio.(2006) Dois Atlânticos. Belo Horizonte, Editora da UFMG/Humanitas.

COTT, Donna Lee Van, The Friendly Liquidation of the past: the politics of diversity in Latin America. Pittsburgh, University of Pittsburgh Press, 2000.

CUNHA, Gomes M. O. (2000) “Movimentos negros e política de identidade no Brasil”. IN: cultura e politica nos movimentos sociais latino-americanos. Belo Horizonte, Ed. UFMG.

DEGLER, Carl N. (1976) Nem branco nem preto: escravidão e relações raciais no Brasil e nos Estados Unidos. Rio de Janeiro: Labor do Brasil.

Dossiê: os Movimentos sociais e a construção democrática. Idéias: Revista do Instituto de Filosofia e Ciências Humanas. Unicamp, 1998-1999.

EDELMAN, Marc (2001). "Social Movements: Changing Paradigms and forms of politics". Annu. Rev.Antropol.

EUFRÁSIO, Mario A. (1995). “A formação da escola sociológica de Chicago" Plural: revista do programa de pós-graduação em sociologia, São Paulo, n. 2.

(1999). Estrutura urbana e ecologia humana: a escola sociológica de chicago (1915-1940).Editora 34. Universidade de São Paulo.

FERNANDES, Florestan (1955). "A luta contra o preconceito de Cor". In: BASTIDE e FERNANDES (Orgs.). Relações raciais entre negros e brancos em São Paulo. São Paulo, Editora Anhembi. 
Paulo. Editora Anhembi.

(1964). A integração do negro na sociedade de classes. Universidade de São (1972). O negro no mundo dos brancos. Universidade de São Paulo. Difusão Européia do Livro.

(1989). O significado do protesto negro. Cortez Editora. São Paulo.

FRAZIER, Franklin (1942). "Some Aspects for Race Relations in Brazil", Phylon-Review of Race and Culture, III, 3.

FREYRE, Gilberto (2003). Casa-Grande \& Senzala: formação da familia brasileira patriarcal. Rio de Janeiro, Editora Global.

.(1936) Sobrados e Mucambos. José Olympio. Rio de Janeiro.

FRIEDMAN, Debra; MCADAM, Doug (1992)“Collective Identity and Activism”. In Frontiers. In Morris; Mueller (Orgs). Frontiers Social Movement Theory. Yale University Press.

FRY, Peter (1996). “A cinderela negra” . IN Revisa USP, São Paulo. N. 28. p.122-135.

CUNHA JUNIOR, Henrique (2002) In: FONSECA e ANDRADE(orgs). Aprovados! São Paulo, Selo Negro.

GARCIA, Januário (2007). 25 anos de movimento negro no Brasil. Brasília. Ministério da Cultura/ Fundação Palmares.

GIACOMINI, Sonia Maria. (2006). A alma da festa. Belo Horizonte Ed. UFMG.

GOMES, Flávio (2005). Negros e Política. Rio de Janeiro.Jorge Zahar Editor.

GOMES, Joaquim Barbosa (2003). "Debate constitucional sobre ações afirmativas" IN SANTOS e LOBATO, Ações Afirmativas. DP\&A Editora.

GONZALEZ, Lélia (1982). "O movimento negro na última década” In: O Lugar do Negro. Rio de Janeiro. Ed. Ponto Zero.

GOHN, Maria da Glória. (2004). Teorias dos movimentos sociais. São Paulo, Edições Loyola.

GORENDER, Jacob (1991). "Sob o Signo da Negação” In: A escravidão reabilitada. São Paulo, Ática, 1990; 2. ed.

GUIMARÃES, Antonio Sérgio. (1998). "O recente anti-racismo brasileiro; o que diziam os jornais de 1988?” In: Racismos e Preconceito Racial. Editora 34.

. (1999). Racismo e Anti-Racismo no Brasil. São Paulo, Editora 34.

Paulo, V.14, n. 41. . (1999). “A marca da Cor”. Revista Brasileira de Ciências Sociais. São 
Editora 34.

. (2002). “Classes Sociais”. In: Classes Raças e Democracia. São Paulo,

(2003). “Acesso de Negros às Universidades". Cadernos de Campo. Cadernos de Pesquisa, n. 118, março/ 2003, pp.247-268.

(2004). "O projeto Unesco na Bahia". Comunicação ao Colóquio Internacional: "O projeto Unesco no Brasil: uma volta crítica ao campo 50 anos depois". http://www.fflch.usp.br/sociologia/asag/

ações afirmativas no governo Lula". No prelo.

GUIMARÃES, Antonio Sérgio; MACEDO, Marcio (2008). "Diário Trabalhista e Democracia Racial Negra nos anos de 1940”. In: Dados. Vol. 51. IUPERJ.

HABERMAS, Jurgen (1981). “New Social Movements”. Telos, n.49, p.33-37.

HANCHARD, Michael. (2001) Orfeu e o poder. Rio de Janeiro, EDUERJ.

.(1996a) "Resposta a Luiza Bairros". Afro-Àsia, n.18, p.227-233.

.(1996b) "Cinderela Negra? Raça e esfera pública no Brasil”. Estudos Afro-

Asiáticos, Rio de Janeiro, n.30 pp.41-59.

HARRIS, Marvin (1967). Padrões Raciais nas Américas. Rio de Janeiro, Ed. Civilização Brasileira.

HASENBALG, Carlos (2005). Discriminação e desigualdades raciais no Brasil. Belo Horizonte. Editora UFMG.

HERINGER, Rosana (2000). “A agenda anti-racista das ong's brasileiras nos anos 90. In: Guimarães e Huntley. Tirando a Máscara. Paz e Terra. São Paulo: Paz e Terra.

(2001). "Mapeamento de Ações e Discursos de Combate às Desigualdades

Raciais no Brasil". IN: Estudos Afro-Asiáticos, Ano 23, n² 2, pp. 1-43

HOFBAUER, Andreas (2006). Uma história de branqueamento ou o negro em questão. São Paulo, Editora UNESP.

JASPER, James (2003). 'The emotions of protest' In: Goodwin, Jeffrey and Jasper, James. The Social Movement Reader. London, Blackwell.

HOOKER, Juliet (2005). Indigenous Inclusion/Black Exclusion: Race, Ethnicity and Multicultural Citizenship in Latin America. Journal of Latin American Studies, N.37.

KÖSSLING, Karin Sant' Anna. (2007) As lutas anti-racistas de afro-descendentes sob vigilância do Deops/Sp (1964-1983). Dissertação de História. São Paulo. 
MAGGIE, Ivonne (1994). “Cor, hierarquia e sistema de classificação”. In Estudos Históricos, Rio de Janeiro, Vol.7, n.14. pp.1949-1960.

(2001). “Os novos bacharéis: a experiência do pré-vestibular para negros e carentes”. In Novos Estudos Cebrap, n.59. pp193-202.

MAIO, Marcos C. (1997). A história do Projeto Unesco. Rio de Janeiro, Tese de doutoramento UPERJ.

(1999). "O projeto Unesco e a agenda das ciências sociais no Brasil dos anos 40 e 50”. Revista Brasileira de Ciências Sociais, São Paulo, v. 14, n. 41.

MAUÉS, Maria A. M. (1991) Da 'branca senhora' ao 'negro herói' a trajetória de um discurso racial. Estudos Afro-Asiáticos, nº 21, p. 119-129.

MAUÉS, Maria A.M. (1997). Negro sobre negro: a questão racial no pensamento das elites negras brasileiras. Rio de janeiro, doutorado na IUPERJ.

MCADAM, Doug (1982). Political Process and the development black insurgency (1930-1970). Chicago and London. The university of Chicago Press.

MCADAM, Doug (1999). Political Process and the development black insurgency (1930-1970). Chicago and London. The university of Chicago Press. 2a. Edição.

MCADAM, Doug; TARROW, Sidney e TILLY, Charles (2001). Dynamics of Contention. Cambridge University press.

McCARTHY, John D.; ZALD, Mayer (1977). "Resource Mobilization and Social Movements". In American Journal of Sociology. Vol. 82 No.6

MATTIACE, Shannan L. (2005), "Representation and Rights: Recent Scholarship on Social Movements in Latin America", Latin America Research, vol. 40, n¹.

MELUCCI, Alberto. (1988). "Getting involved: Identity and mobilization in social movements". A Research Annual. London.

Paulo. . (1989).“Um objetivo para os Movimentos Sociais?” In: Lua Nova. São (1994). Movimentos sociais, Renovação cultural e o papel do conhecimento. Entrevista concedida a Avritzer e Lyyra. Novos Estudos, n. 40.

(1995). "The Process of Collective Identity. In Social Movements and Culture. Johnston; Klandermans (orgs) University of Minnesota Press.

(1996). Challenging Codes. Cambridge University Press.

MENDONÇA, Lúcia F. M. (1996) Movimento Negro: Da marca da inferioridade racial a construção da identidade étnica. Dissertação de Mestrado. São Paulo. FFLCH. 
MESQUITA, Érica. (2003) “Clóvis Moura e a Sociologia da Práxis”. In Estudos Afro-Asiáticos, Rio de Janeiro. Ano 25, no 3.

. (2002) Clóvis Moura: uma visão crítica da história social brasileira. Campinas, Dissertação de Mestrado/Unicamp.

MITCHELL, Michael J. (1977) Racial consciousness and the political attitudes and behavior of blacks in São Paulo. Tese de doutorado apresentado na Universidade de Indiana.

MOURA, Clóvis (1981). “Organizações negras” In: São Paulo: O povo em movimento. Singer e Brand (orgs.), Petrópolis, Ed. Vozes.

MONTEIRO, Simone; MAIO, Marcos Chor (2008). "Cor/Raça, Saúde e Política no Brasil”. In PINHO; SANSONE(orgs). Salvador, EDUFBA.

MUELLER, Carol McClurg (1992). "Building Social Movement Theory". In: Morris; Mueller (Orgs). Frontiers Social Movement Theory. Yale University Press.

MUNCK, Gerardo L. (1997) "Formação de atores, coordenação social e estratégia política" Dados. Rio de Janeiro.

NASCIMENTO, L. Elisa; NASCIMENTO, Abdias. (2000) "Reflexões sobre o movimento negro no Brasil, 1938-1997”. In: Guimarães e Huntley. Tirando a Máscara. Paz e Terra. São Paulo: Paz e Terra.

NASCIMENTO, Maria E. (1989). “A estratégia da desigualdade: o movimento negro dos anos 70”. São Paulo, Dissertação de mestrado/PUC.

NETO, José Laudelino (1986). A pastoral do Negro no Brasil após o vaticano II: uma análise da origem da pastoral do negro no Brasil após o vaticano II nas práticas e ações da Igreja Católica. Rio de Janeiro, Dissertação de Mestrado. Departamento de Teologia/PUC.

NOGUEIRA, Oracy (1998). Preconceito de Marca: Relações Raciais em Itapetininga. São Paulo, Edusp.

(1998). "Preconceito racial de marca e preconceito racial de origem". In: Tanto Preto Quanto Branco: estudos de relações raciais. São Paulo: ed. T. Queiroz.

PALLARES-BURKE, Maria L. (2005). Gilberto Freyre, um vitoriano dos trópicos. Ed. UNESP. PICHARDO, Nelson (1997). "New social movements: a critical review". In: Annual Review of sociology, v.23. pp. 411-430.

PIERSON, Donald (1971). Brancos e Pretos na Bahia. São Paulo, Companhia Editora Nacional.

PINTO, Costa (1953). O negro no Rio de Janeiro: relações de raças numa sociedade em mudança. São Paulo. Companhia Editora Nacional. 
POLETTA, Francesca (2006). It was like a fever story telling in protest and politics. Chicago. University of Chicago Press.

QUEIROZ, Maria. P. P. (1978). "Coletividades negras: ascensão sócio-econômica dos negros no Brasil e em São Paulo". In: Cultura, sociedade rural, sociedade urbana. Ensaios. São Paulo. Editora Universidade de São Paulo.

São Paulo. N.27(7).

(1975). “Classes sociais no Brasil”. In: Revista Ciência e Cultura.

RAMOS, Arthur (1936).O negro na Civilização Brasileira. Rio de Janeiro. Livraria Editora da Casa do Estudante do Brasil.

Municipal de São Paulo.

.(1938). "O espírito associativo do negro brasileiro". In: Revista do Arquivo

RATTS, Alex.(2007).Eu Sou Atlântica. São Paulo. Imprensa Oficial/ Instituto kuanza.

ROLAND, Edna.(2000). "Movimento de Mulheres Negras Brasileiras". In: GUIMARÃES e HUNTLEY. Tirando a Máscara. Paz e Terra. São Paulo: Paz e Terra.

RUFINO, Joel. (1985). "O Movimento Negro e Crise Brasileira", Revista Política e Administração. Rio de Janeiro. Vol.2.

SADER, Eder; PAOLI, Maria C.(2004). "Sobre as classes populares no pensamento sociológico brasileiro" In: CARDOSO, R.(Org.) Aventura Antropológica. $4^{\circ}$ ed. São Paulo: Paz e Terra.

SALlUM, Brasílio. (2000) "O Brasil sob Cardoso" (2000). In: Tempo Social, Revista de Sociologia da USP, São Paulo: pp.23-47.

SALLUM, Brasílio; KUGELMAS (2004). "Sobre o modo Lula de Governar" In: SALLUM (org), Brasil e Argentina Hoje. Bauru-SP; EDUSC. pp.255-287.

Santos, David. (2003) Pré-vestibular comunitário, universidade e ações afirmativas. In: Fonseca, Denise Pini Rosalem da (Org.). Resistência e Inclusão. Rio de Janeiro: PUC; Consulado Geral dos EUA, p. 153-156

SANTOS, Gevanilda.(1992) Etnia Negra e Partidos Políticos. Dissertação de Mestrado/PUC. São Paulo.

SANTOS, Márcio Oliveira (2005). A Persistência Política dos Movimentos Negros Brasileiros: Processo de Mobilização à $3^{a}$ Conferência Mundial das Nações Unidas Contra o Racismo. Dissertação de Mestrado em Ciências Sociais/UERJ.

SANTOS, Renato Emerson (2006). Agendas \& agências: a espacialidade dos movimentos sociais a partir do Pré-Vestibular para Negros e Carentes. Rio Janeiro.Tese de doutorado em Geografia da Universidade Federal Fluminense. 
SANTOS, Ivair Augusto dos.(2006) O movimento negro e o Estado (1983-1987).São Paulo, CONE: Prefeitura de São Paulo.

SCHWARCZ, Lilia K. M. (1990) De festa também se vive: reflexões sobre o centenário da abolição em São Paulo. Estudos Afro-Asiáticos, Rio de Janeiro, nº 18, p. 13-25.

SEBASTIÃO, Angélica Ana (2007). Memória, Imaginário e Poder: Práticas Comunicativas e de Ressignificação das Organizações de Mulheres Negras. Rio de Janeiro, Dissertação de Mestrado/ UFRJ.

SEYFERTH, Geralda (1983). "Etnicidade Cidadania e algumas considerações sobre as bases étnicas da mobilização política". Boletim do Museu Nacional. Rio de Janeiro. N. 42. V.20.

SILVA, Joana M. P. (1994) Centro de cultura e arte negra: trajetória e consciência étnica. São Paulo, Dissertação de Mestrado/PUC.

SILVA, Jônatas da (1988). "História de lutas negras: escravidão e invenção da liberdade". In: REIS, João J. (Org.) Escravidão e Invenção da Liberdade. Rio de Janeiro; Editora Brasiliense.

SILVA, Maria A. G. (1994) Encontros e desencontros do movimento negro. Brasília, Ministério da Cultura-Fundação Cultural Palmares.

SILVEIRA, Oliveira.(2003). "Vinte de novembro: história e conteúdo" In: SILVERIO e SILVA (Orgs): Entre a injustiça Simbólica e a Injustiça econômica. Inep. Brasília.

SOUZA, Florentina da Silva. (2005) Afro-descendência em Cadernos Negros e Jornal do MNU. Belo Horizonte. Autêntica.

SOUZA, Jessé. (1997). Multiculturalismo e Racismo: o papel da ação afirmativa nos Estados democráticos contemporâneos. Brasília: Ministério da Justiça.

SOUZA JUNIOR, Walter Altino de.(2006) O Ilê Aiyê e a relação com o Estado: interfaces e ambiguidades entre poder e cultura na Bahia. Salvador, Dissertação de mestrado/UFBA.

SWIDLER, Ann.(1986). “Culture in Action”. In: American Sociological Review.

TARROW, Sidney ( 2006). Power in Movement. Cambridge University Press. New York. 2.Ed. . (1992) "Mentalities, Political Cultures and Collective actions frames". In: Morris; Mueller (Orgs). Frontiers Social Movement Theory. Yale University Press.

TEIXEIRA, Ana Cláudia Chaves (2003). Identidades em Construção. São Paulo.Annablume; Fapesp; Insituto Polis.

TELLES., Edward (2003). Racismo à Brasileira. Rio de Janeiro. Relume/Dumará.

TILLY, Charles (2005). "Invention, diffusion and transformation of social movement repertoire”. In: Identities, boundaries and social ties. Paradigm Publishers. Boulder, London. 
. (2004). Social Movements (1768-2004). Paradigm Publishers London.

TONI, Fabiano (2001) "Novos rumos e possibilidades para os estudos dos movimentos sociais". BIB. São Paulo, pp. 79-104 n. 52.

TOURAINE, Alain (1997). “Os movimentos sociais" In Iguais e diferentes. Lisboa. Instituto Piaget.

Cultural.

(1988). Palavra e Sangue. São Paulo.Editora da Unicamp e Trajetória

VIANNA, Luiz Werneck (2007). "O estado novo do PT” In:La Insígnia. http:// www. la insígnia.org.

\section{Fontes consultadas}

\section{Jornais:}

Jornal da Educafro (2006 a 2008)- Tiragem Mensal.

Folha de São Paulo (1988 e1995)

Estado de São Paulo (1988 e 1995)

Jornal O Dia 22/03/2004

Jornal O Globo 19 de julho de 2001

Jornal da Tarde 19 de julho de 2001

Jornal dos Sports 19 de julho de 2001

Jornal Folha Dirigida 14 a 20 de agosto de 2001.

\section{Filmografia:}

BUlBUL, Zózimo.(Direção e Roteiro) (1998). Abolição. Rio de Janeiro, $150 \mathrm{~min}$.

Organizações do Movimento Negro(1996). Documentário "Marcha de Zumbi”, Brasília.

\section{Documentos das Marchas e Manifestos:}

Doc I - Folheto da primeira Marcha Noturna.

Doc. II - Folheto da Segunda Marcha Noturna.

Doc. III - Folheto da Terceira Marcha Noturna. 
Doc. IV - Folheto da Quarta Marcha Noturna.

Doc. V - Folheto da Quinta Marcha Noturna.

Doc. VI - Folheto da Sexta Marcha Noturna.

Doc. VII - Folheto da Sétima Marcha Noturna.

Doc. VIII - Folheto da Oitava Marcha Noturna.

Doc. IX - Folheto da nona Marcha Noturna.

Doc. X - Folheto da Décima Marcha Noturna.

Doc. XI - Folheto da Décima primeira Marcha Noturna.

Doc. XII - Folheto da Décima Segunda Marcha Noturna.

Doc. XIII - Manifesto da XII Marcha Noturna.

Doc. XIV - Manifesto do ato do MNU em Julho de 1979

Doc. XV - Manifesto do Ato de MNU em julho de 2008

Doc. XVI - Relatório da Marcha de Zumbi dos Palmares (1995)

Doc. XVII - Decreto do presidente da República 20/11/08.

\section{Outros documentos:}

- Catálogo Centenário da Abolição (1989). ACEC/ CIEC/ Núcleo da cor/ UFRJ.

- Cartilha dos grupos de base dos Agentes Pastoral Negros.(1987) "Ouvi o clamor deste povo... negro". Rio de Janeiro, Vozes. 2o. Edição.

- Estatuto do CEERT. Disponível em: http:/www.abong.org.br

\section{Consultas a Site:}

- http://www.stevebiko.org.br

- http:/www. viventinho.org.br

- http://www.educafro.org.br

- $\quad$ http://www.geledes.org.br

- http://www.ceert.org.br

Visitas às organizações :

- Visita ao Instituto Padre Batista (em maio e junho de 2007 e 2008).

- Visita ao CEERT (Setembro e outubro de 2007 e 2008)

- Visita a Educafro/RJ (junho e outubro de 2006 e Janeiro e fevereiro de 2008)

- Visita a Educafro São Paulo (2006 e 2007) 


\section{Entrevistas com organizadores da Marcha Noturna:}

- Maria da Penha Guimarães - Fundadora da Marcha Noturna (Maio de 2008).

- Wilson Negão-Presidente da Ong “Fala Negão”. (Maio de 2008)

- Sinvaldo Firmo - Assessor Parlamentar e Coordenador do Instituto do Negro Padre Batista (Junho de 2008). 
Anexo 1 - Lista dos Núcleos da Educafro no Rio de Janeiro 2007/2008

\begin{tabular}{|c|c|c|c|}
\hline Núcleo & Zona & Estabelecimento & Dias de Funcionamento \\
\hline Jesus Sacramento & Norte & Paróquia & Seg. à Sext. Das 19:00 às 21:30 \\
\hline Padre Jose Mauricio & Norte & Paróquia & $2^{\circ} .3^{\circ}$. e $4^{\circ}$. das 19:00 ás 21:40 \\
\hline PRECOM & Norte & Igreja Assembléia de Deus & Seg. à̀ Sex.:19h ás 21:30 \\
\hline Triagem & Norte & Ces José Carlos Brandão & Sáb:08:00 às 19:00 e Dom: 08:00 ás 12:00 \\
\hline Lima Barreto & Norte & Santo Aleixo & Sem informações \\
\hline João Paulo II & Norte & Paróquia Sta Cecília & Sáb: 08:00 ás 17:00hs \\
\hline Dona Marta & Sul & Sem informações & $2^{\mathrm{a}}, 3^{\mathrm{a}}, 5^{\mathrm{a}} \mathrm{e} 6^{\mathrm{a}}: 19 \mathrm{~h}$ às $22 \mathrm{~h} /$ Sáb.8h às $13 \mathrm{~h}$ \\
\hline Horto & Sul & Sem informações & Seg á Sex 19hs ás 22h \\
\hline Fidel Castro & Maricá & Ciep de Marica & Terça e Quinta: 18:00 ás 22hs \\
\hline Almirante Negro & Centro & Santuário nossa srahora de Fátima & Sáb. 8h às 20h e Dom 8:00 á 12:00 \\
\hline Martin Luther king & Centro & Igreja Presbiteriana & Sáb.: 7h às 19h \\
\hline Proced & Centro & Igreja Batista & Sem informações \\
\hline Casa do menor trabalhador & Centro & Central do Brasil & Sáb:08:00 ás 17:00hs \\
\hline Santíssimo & Oeste & CEFM & Seg. à Qui 19h às22h ou Dom $8 \mathrm{~h}$ às $13 \mathrm{~h}$ \\
\hline Canaã & Oeste & $1^{\mathrm{a}}$ Igreja Batista de Bangu & Seg.à Sex.18h ás21h45 / Sab.8h às13h \\
\hline Amai & Oeste & Escola est. Pde Leonel Franca & Seg. à Sex.:18h às $22 \mathrm{~h}$ \\
\hline Cidadania para todos & Oeste & Igreja Batista de Vila Realengo & Seg. à Sex.19h ás 22h/ \\
\hline Pioneiro de Realengo & Oeste & ciep 244 Oswaldo Aranha & Sab.:.8h às17h / Dom.8h às $16 \mathrm{~h}$ \\
\hline Vila Aliança & Oeste & Igreja Menino Jesus de Praga. & Seg. à Sext.19h às $22 \mathrm{~h} / \mathrm{Sab}: .8 \mathrm{~h}$ às $12 \mathrm{~h}$ \\
\hline Che Guevara & Oeste & C.Educ. Novo Horizonte. & Seg. à Sex.19h às22h /sab.8h às17h \\
\hline Jd.Boiúna-Jacarépaguá & Oeste & Paróquia São Bartolomeu & Seg á Sex 19:00 ás 22:00 \\
\hline Abdias do Nascimento & Oeste & Ass. de moradores de Jd. Boiuna & Seg. à Qui.: $18 \mathrm{~h}$ às $21 \mathrm{~h} 40$ / Sab.: $8 \mathrm{~h}$ às $20 \mathrm{~h}$ \\
\hline CUC & Oeste & Caic-Rio das Pedras & Sab e Dom de 8:00 ás 15hs \\
\hline João Cândido & Oeste & Ass. de moradores de Jd. Boiuna & Seg. à Sex.:19h às 21h20 / Sab.8h ás $18 \mathrm{~h}$ \\
\hline Superação & Oeste & Colégio Estadual & Sab.: 7h às19h10 / Dom.:8h às10h30 \\
\hline Paulo Freire & Oeste & Igreja Batista & Seg, Ter,Qua Qui. Sex. 18 h30 às 21h50 \\
\hline Praça Seca & Oeste & Escola Estadual & Seg. à Sex. $18: 30$ às $22 \mathrm{hs}$ \\
\hline Pastor Luiz Eduardo Nascime & Oeste & Centro Espírita & Sab.: 7h30 às 19h / Dom.: 16h às 17h30 \\
\hline N. Senhora de Fátima & Oeste & Próx ao Pier da Prefeitura & Sáb: 08:00 ás 18:00. \\
\hline Sem informação & Oeste & Paróquia & Seg á Sex 18:30 ás 21:00 \\
\hline
\end{tabular}


Anexo 2 - Lista dos Núcleos da Educafro na Grande Rio 2007/2008

\begin{tabular}{|c|c|c|c|}
\hline Núcleo & localização & Tipo de estabelecimento & Horários e Dias de Funcionamento \\
\hline Ajusp & Belford Roxo & Centro educacional & Sáb.:7h às19:00h / Dom.7h às $13 \mathrm{~h}$ \\
\hline Garra & Belford Roxo & Igreja Batista & Sáb.:7h às19:00h / Dom.7h às $13 \mathrm{~h}$ \\
\hline Objetivo & Duque de Caxias & Escola Objetivo,. & Sab.: $8 \mathrm{~h}$ às $20 \mathrm{~h}$ \\
\hline Centenário & Duque de Caxias & Escola Estadual & Sem informações \\
\hline Clementina Jesus & Duque de Caxias & Ciep Clementina de Jesus & Sem informações \\
\hline Jardim Leal & Duque de Caxias & Colegio.Fidélis Medeiros & Sab.:7:30h às $19: 30 \mathrm{~h} /$ \\
\hline Tim Lopes & Duque de Caxias & Escola & Sab.:8h às $18: 30 \mathrm{~h}$ e Dom.:8h às17:00h \\
\hline Daniel Camboni & Duque de Caxias & Sem informações & Sem informações \\
\hline Xerém & Duque de Caxias & Colégio .Estadual & Sábado $08 \mathrm{~h}$ às $20 \mathrm{~h}$ \\
\hline P. de Miguel Couto & Nova Iguaçu & Igreja Católica & Sáb. $8 \mathrm{~h}$ às $18: 30 \mathrm{~h} /$ Dom. $8 \mathrm{~h}$ às $12: 30 \mathrm{~h}$ \\
\hline Educar p/ vida & Nova iguaçu & Centro Com.Ir Anita & $\begin{array}{c}\text { Seg. à Sex.19:00às22:00 Sab.8h às18h.Dom:à critério do } \\
\text { professor }\end{array}$ \\
\hline $\mathrm{Nec}$ & Nova Iguaçu & Colégio estadual & Sab.: $8 \mathrm{~h}$ às18:10h / Dom.8h às14h \\
\hline Central de Niterói & Niterói & Igreja Metodista & Sáb.: $8 \mathrm{~h}$ às17h \\
\hline Matriz & São João do Meriti & Escola Estadual & Sab.7h às19h / Dom.8h às14h \\
\hline S. Francisco de Assis & São João do Meriti & Igreja Católica & Seg á Sex: 19:00 ás 22:00 \\
\hline Sagrado C. de Jesus & São João do Meriti & Escola Estadual & Quin. e Sext.19h às 21h / Sab.8h às15:00 \\
\hline Darcy Ribeiro & São João do Meriti & Igreja Batista & Seg. à Sex.: $18: 30$ às $22 \mathrm{~h}$ \\
\hline São Mateus & São João do Meriti & Igreja Católica & Sab.:7h às19h / Dom.:7h às17h \\
\hline Estrela de Davi & São João do Meriti & Associação de Moradores; & Seg. à Sex.: $19 \mathrm{~h}$ às $22 \mathrm{~h}$ \\
\hline Coelho da Rocha & São João do Meriti & Colégio Estadual & Sab.:8h às19h30/Dom. $8 \mathrm{~h}$ às13h \\
\hline Tina Pacheco & São João do Meriti & Sem informações & Sábado 08 ás 19:30h / Dom:08 ás 14h \\
\hline São João Batista & São João do Meriti & Sem informações & Sábado 08 as 20 horas \\
\hline ODARA & São João do Meriti & Sem informações & Sem informações \\
\hline TOMAZINHO & São João do Meriti & Sem informações & Sáb: 08:00hs ás $18: 00 \mathrm{hs}$ \\
\hline VICENTINHO & São João do Meriti & Sem informações & Sáb: 08:00 ás 18:00hs \\
\hline
\end{tabular}




\section{Anexo 3- Lista dos Entrevistados da Educafro}

\begin{tabular}{|c|c|c|c|c|}
\hline Entrevistados & $\begin{array}{l}\text { Tipo de Vínculo } \\
\text { com a Instituição }\end{array}$ & Instituição & Local de Residência & $\overline{\text { Data }}$ \\
\hline Fábio & $\begin{array}{l}\text { Ex-bolsista e Assessor } \\
\text { Jurídico/ Políticas Públicas }\end{array}$ & Educafro/RJ & $\begin{array}{l}\text { Nilópolis-Baixada Fluminense/ } \\
\text { RJ }\end{array}$ & $20 / 07 / 06$ \\
\hline Célia & $\begin{array}{l}\text { Ex-aluna e Coordenadora } \\
\text { Pedagógica }\end{array}$ & $\begin{array}{l}\text { Educafro-Baixada } \\
\text { Fluminense }\end{array}$ & $\begin{array}{l}\text { Duque de Caxias - Baixada } \\
\text { Fluminense/RJ }\end{array}$ & $22 / 07 / 06$ \\
\hline Samantha & $\begin{array}{llll}\text { Ex-aluna } & \text { e } & \text { Coord. } & \text { de } \\
\text { Núcleos } & & & \end{array}$ & Educafro/RJ & Mesquita-Baixada Fluminense/RJ & $23 / 07 / 06$ \\
\hline Maurício & $\begin{array}{l}\text { Ex-aluno e } \text { Coordenador } \\
\text { Administrativo }\end{array}$ & Educafro/ SP & Guarulhos/SP & $26 / 08 / 06$ \\
\hline Frei Evandro & $\begin{array}{l}\text { Fundador do cursinho para } \\
\text { negros e carentes em São } \\
\text { Luis }\end{array}$ & Educafro/SL & São Luis / MA & $22 / 09 / 06$ \\
\hline André G. & $\begin{array}{l}\text { Ex-aluno } \mathrm{e} \text { Coord. } \\
\text { núcleos regional }\end{array}$ & Educafro/RJ & $\begin{array}{l}\text { São João do Meriti- Baixada } \\
\text { Fluminense/RJ }\end{array}$ & $28 / 10 / 06$ \\
\hline André & Coord. Geral da Regional & Educafro/RJ & Cidade do Rio de Janeiro & $29 / 10 / 06$ \\
\hline Solange & $\begin{array}{ccc}\text { Ex-aluna } & \text { e } & \text { Coord. } \\
\text { Administrativa } & & \end{array}$ & Educafro/RJ & Cidade do Rio de Janeiro & $27 / 10 / 06$ \\
\hline Sandra & $\begin{array}{l}\text { Secretária e bolsista em } \\
\text { Universidade conveniada à } \\
\text { Educafro }\end{array}$ & Educafro/RJ & $\begin{array}{cc}\text { Nilópolis } & \text {-Baixada } \\
\text { Fluminense/RJ } & \end{array}$ & $29 / 10 / 06$ \\
\hline Patrícia & $\begin{array}{l}\text { Bolsista } \\
\text { ELAM/Venezuela }\end{array}$ & Educafro/DF & Brasília/ D.F & $02 / 11 / 06$ \\
\hline Vinícius & $\begin{array}{l}\text { Bolsista } \\
\text { ELAM/Venezuela }\end{array}$ & Educafro/ABC & Santo André/SP & $04 / 11 / 06$ \\
\hline Douglas & $\begin{array}{l}\text { Coordenador de Núcleo da } \\
\text { Educafro/SP }\end{array}$ & Educafro/ SP & São Paulo/SP & $17 / 11 / 06$ \\
\hline Edvan & $\begin{array}{llll}\text { Ex-aluno } & \text { e } & \text { ex-bolsista- } \\
\text { Professor } & \text { de } & \text { núcleo em } \\
\text { Guarulhos } & & & \end{array}$ & Educafro/ SP & São Paulo/SP & $28 / 11 / 06$ \\
\hline Cleber & $\begin{array}{l}\text { Bolsita } \\
\text { ELAM/Cuba }\end{array}$ & Educafro/SP & Cuba & $18 / 08 / 07$ \\
\hline Leon & Professor de núcleo & Educafro/SP & São Bernando/SP & $15 / 01 / 08$ \\
\hline
\end{tabular}




\section{Anexo 4}

\section{Hino da Negritude*: Letra e melodia de Eduardo Oliveira \\ I}

Sob o céu cor de anil das Américas / Hoje se ergue um soberbo perfil./E u'a imagem de luz Que, em verdade, traduz/ A história do Negro no Brasil./Este povo, em passadas intrépidas, Entre os povos valentes se impôs./Com a fúria dos leões/Rebentando grilhões/Aos tiranos se contrapôs.

\section{Estribilho}

Ergue a tocha no alto da glória/Quem herói, nos combates, se fez/Pois, que as páginas da história,/São galardões aos negros de altivez.

\section{II}

Levantado no topo dos séculos,/Mil batalhas viris sustentou,/Este povo imortal

Que não encontra rival,/Na trilha que o amor lhe destinou./Belo e forte, na tez cor de ébano

Só lutando se sente feliz./Brasileiro de escol

Luta de sol a sol/Para o bem de nosso País.

\section{III}

Dos Palmares, os feitos históricos/São exemplos da eterna lição

Que, no solo tupi,/Nos legara Zumbi,/Sonhando com a liberação.

Sendo filhos, também da mãe África,/Aruanda dos Deuses da Paz.

No Brasil, este AXÉ/Que nos mantém de pé/ Vem da força dos Orixás.

IV

Que saibamos guardar estes símbolos/De um passado de heróico labor.

Todos numa só voz,/Bradam nossos avós:/Viver é lutar com destemor.

Para frente marchamos impávidos/Que a vitória nos há de sorrir.

Eia, pois, cidadãos/Somos todos irmãos/Conquistando o melhor porvir.

Extraído de http://pt.wikisource.org/wiki/Hino_\%C3\%A0_Negritude, que por sua vez retirou o hino do Diário Oficial da Cidade de São Paulo de 11 de julho de 2007, página 3, foi publicado tendo ao término da letra a observação Registrado na Escola Nacional de Música da Universidade do Brasil, em 1966. 


\section{Anexo 5: Entidades organizadoras da XII Marcha Noturna*:}

\begin{tabular}{|l|l|}
\hline Organizações negras & outras organiza ções \\
\hline Fala negão & Central Única dos Trabalhadores (CUT) \\
\hline Educafro & Secretária do Estado da Cultura \\
\hline espaço cultura negro sim & Coord. Especial dos assuntos da População negra (CONE) \\
\hline GMR Unidos da Peruche & Apeoesp \\
\hline Brasil Afirmativo & Paróquia nossa senhora de Fátima \\
\hline Coletivo Alumia & Sindicato dos advogados do Estado de São Paulo \\
\hline Ilê Axé Odezava & Coordenadoria do Negro contra a discriminação racial \\
\hline Conegro - latapecerica da Serra & INSPIR- \\
\hline Pastoral Afro-Aquiropita & Fipir Alto T ietê \\
\hline Pastoral Afro-Aquiropita & Cades \\
\hline Instituto do Negro Padre Batista & Sindicato dos Advogados do Estado de São Paulo \\
\hline Grupo Espaço Negro & Cadesc \\
\hline APN's 25 anos & Grupo corso \\
\hline Movimento humanista & Gênero e cidadania - Mauá \\
\hline Ilê Axé Odezava & intecab \\
\hline Familia Amani & Cncdr \\
\hline
\end{tabular}

* Segundo panfleto e blog de divulgação da XII Marcha. Visita: 22/05/08. 


\section{Anexo 6: Passeatas, Marchas, Atos e Ocupações}

\begin{tabular}{|l|l|l|l|}
\hline Protesto & Data & Local & Tecnicas de coleta de dados \\
\hline Ato do MNU & $7 / 7 / 1979$ & São Paulo & Consulta a bibliografia, fotografias, documentos e jornais. \\
\hline Marchas do Centenário da Abolição & $11 / 5 / 1988$ & Rio de Janeiro & Consulta a bibliografia, fotografias, documentos e jornais. \\
\hline Marcha do Tricentenário de Zumbi & $20 / 11 / 1995$ & Brasilia & Consulta a bibliografia, documentos e a fotografias e audiovisual. \\
\hline III Marcha do 20 de novembro & $20 / 11 / 2006$ & São Paulo & Observação, entrevistas e consulta a documentos e jornais. \\
\hline Marcha Zumbi+10 & $21 / 11 / 2006$ & Brasilia & Consulta a material audiovisual, documentos e jornais. \\
\hline & & & \\
\hline Ocupação da Faculdade de Direito & $12 / 9 / 2007$ & São Paulo & Observação e entrevistas. \\
\hline IVMarcha do 20 de Novembro & $20 / 11 / 2007$ & São Paulo & Observação, entrevistas, material visual, documentos e jornais. \\
\hline XI Marcha Noturna & $12 / 5 / 2007$ & São Paulo & Observação, entrevistas e consulta a material visual, documentos \\
\hline XII Marcha Noturna & $12 / 5 / 2008$ & São Paulo & Observação, entrevistas e consulta a documentos visuais e a jornais. \\
\hline Ato público de 30 anos de MNU & $7 / 7 / 2008$ & São Paulo & Observação e entrevistas. \\
\hline
\end{tabular}

